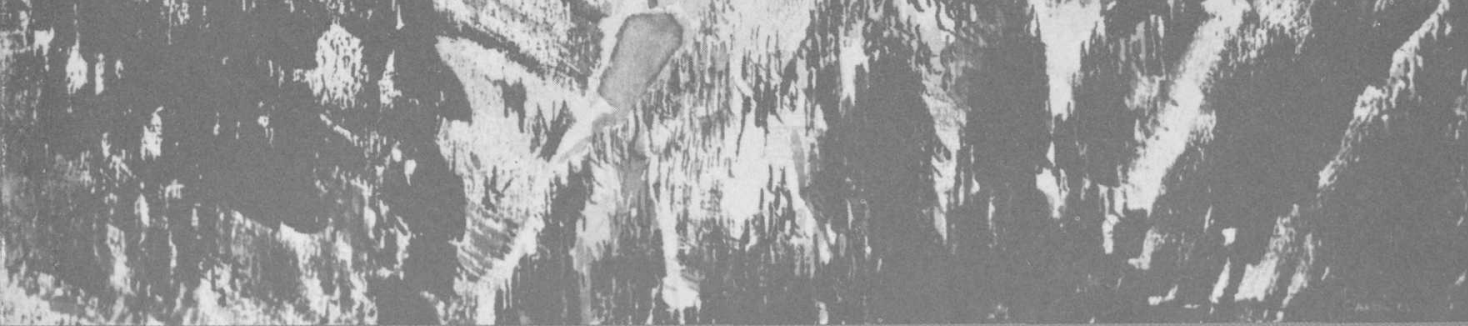

AREAS CONTIGUOUS TO THE

UNCOMPAHGRE PRIMITIVE AREA, SOUTHWESTERN COLORADO

GEOLOGICAL SURVEY BULLETIN 1391-E 


\section{Mineral Resources of Study Areas}

\section{Contiguous to the}

\section{Uncompahgre Primitive Area, \\ San Juan Mountains, \\ Southwestern Colorado}

By T. A. STEVEN, P. W. LIPMAN, F. S. FISHER, U.S. Geological Survey

and by C. L. BIENIEWSKI, and H. C. MEEVES,

U.S. BUREAU OF Mines

With a section on

INTERPRETATION OF AEROMAGNETIC DATA

By PETER POPENOE and R. G. LUEDKE, U.S. Geological Survey

STUDIES RELATED TO WILDERNESS-PRIMITIVE AREAS

G E O L O G I C A L S U R V E Y B U L L E T I N 1 $33^{\prime} 1$ - E

An evaluation of the mineral

potential of the area

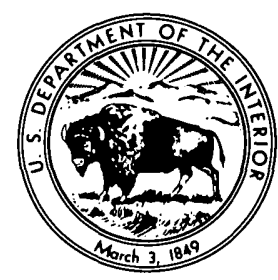

UNITED STATES GOVERNMENT PRINTING OFFICE, WASHINGTON : 1977 


\section{UNITED STATES DEPARTMENT OF THE INTERIOR}

CECIL D. ANDRUS, Secretary

\section{GEOLOGICAL SURVEY}

V. E. McKelvey, Director

Library of Congress Cataloging in Publication Data

Main entry under title:

Mineral resources of study areas contiguous to the Uncompahgre primitive area, San Juan

Mountains, southwestern Colorado.

(Studies related to wilderness-primitive areas)

(Geological Survey Bulletin 1391-E)

Bibliography: p.

Includes index.

Supt. of Docs. no.: I 19.3:1391-E

1. Mines and mineral resources-Colorado-San Juan Mountains.

I. Steven, Thomas August, 1917- II. Series: United States Geological Survey Bulletin 1391-E. QE75.B9 no. 1391-E [TN24.C6] 557.3'08s [553'.097881] 76-608153

For sale by the Superintendent of Documents, U.S. Government Printing Office

Washington, D.C. 20402

Stock Number 024-001-02964-2 


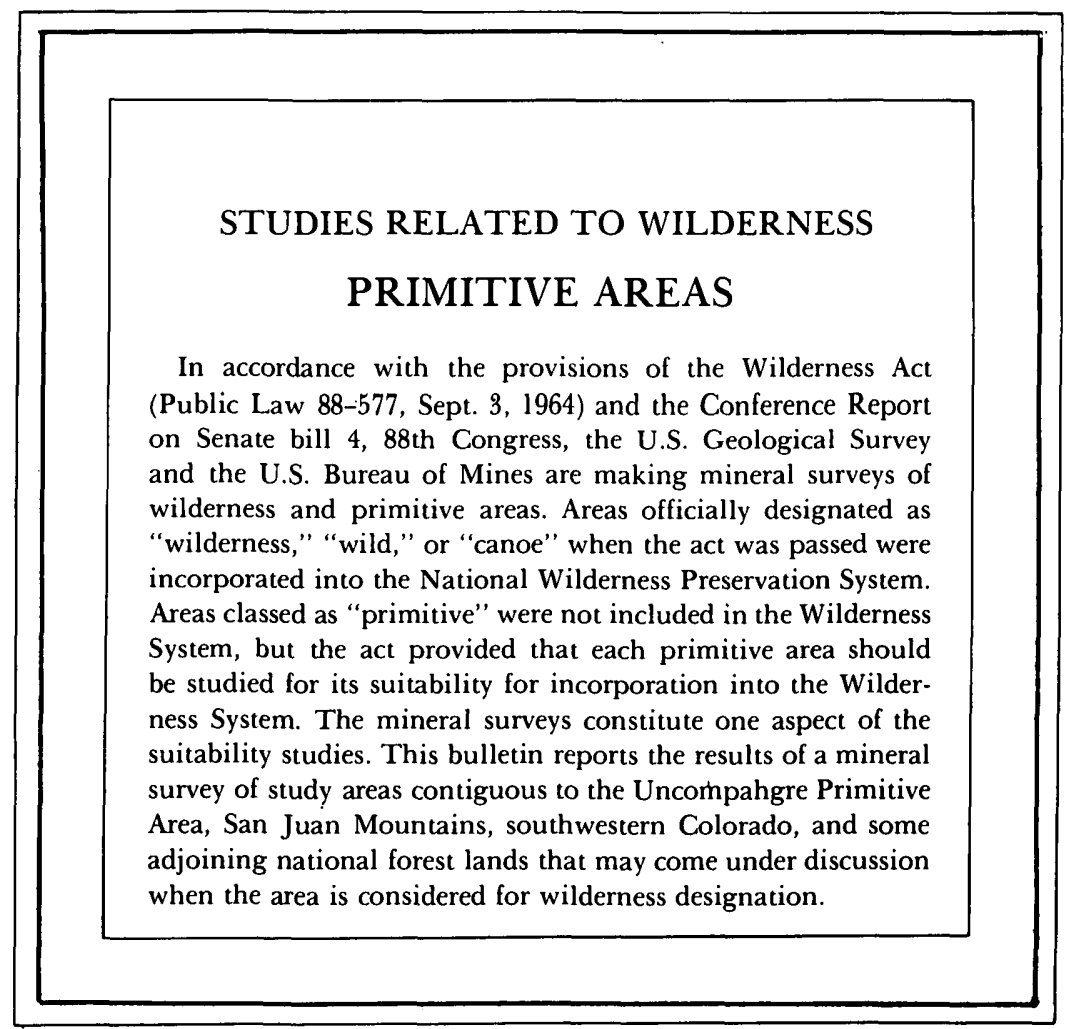





\section{CONTENTS}

Summary

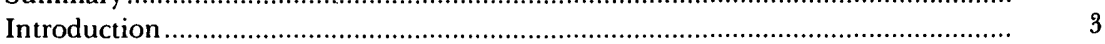

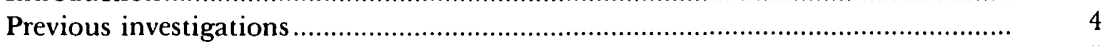

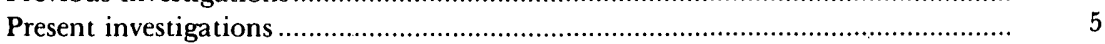

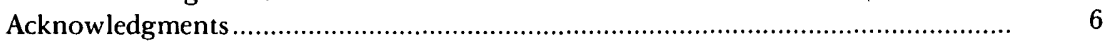

Geologic appraisal, by T. A. Steven, P. W. Lipman, and F. S. Fisher..................... 7

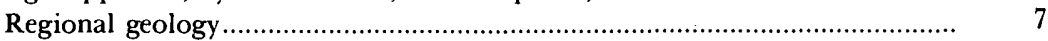

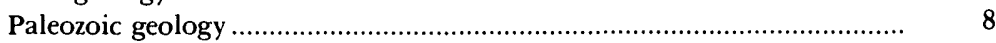

Mesozoic geology ...................................................................

Telluride Conglomerate ..................................................................... 14

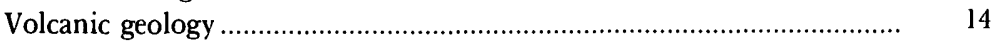

Early intermediate volcanics ...............................................................

Ash-flow tuffs and associated rocks...................................................... 15

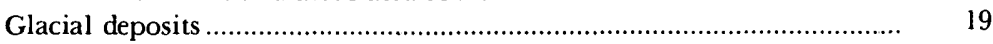

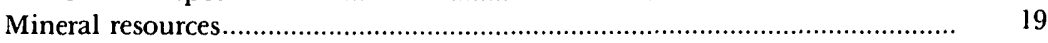

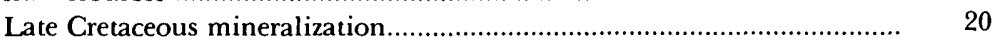

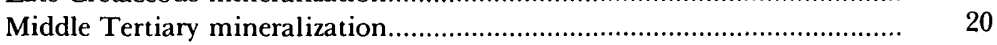

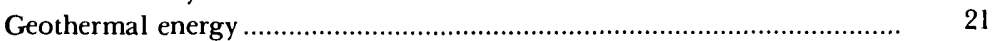

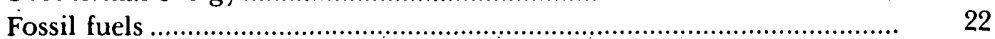

Western contiguous area ........................................................................ 24

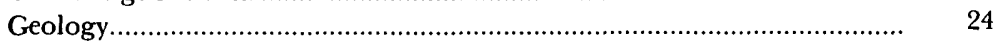

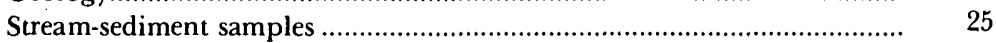

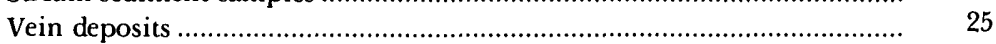

Central contiguous area ..................................................................... 27

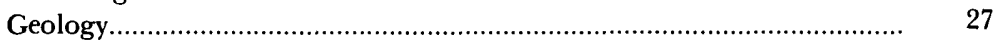

Stream-sediment samples ................................................................. 28

Vein and replacement deposits .................................................... 28

Eastern contiguous area ....................................................................

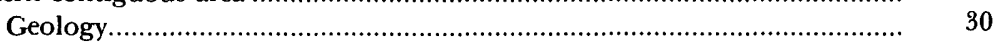

Stream-sediment samples ............................................................ 31

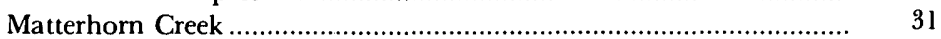

Yellowstone Gulch ....................................................................

El Paso Creek ........................................................................ 32

Southern and southeastern streams ......................................................

Northeastern and northern streams ............................................... 34

East Fork Cimarron River ...........................................................

Middle Fork Cimarron River.............................................................

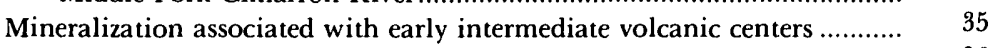

Larson center......................................................................... 36

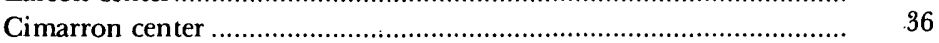

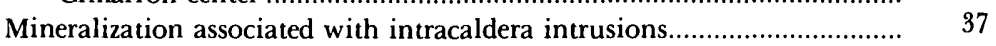

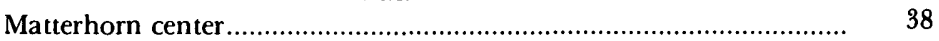

Capitol City mining area ......................................................... $\quad 39$

Altered area at Iron Beds....................................................... 40 
Geologic appraisal-Continued Page

Eastern contiguous area-Continued

Mineralization associated with intracaldera intrusions-Continued

Veins along Henson Creek

Mineralization associated with rhyolite intrusions ................................... 41

Geochemical data ..................................................................... 42

Economic significance ................................................................... 45

Interpretation of aeromagnetic data, by Peter Popenoe and R. G. Luedke............. 47

Magnetic susceptibility measurements............................................................... 47

Western Uncompahgre Primitive Area and western contiguous study area..... 51

Central Uncompahgre Primitive Area and central contiguous study area....... 52

Eastern Uncompahgre Primitive Area and eastern contiguous study area........ 53

Economic appraisal, by C. L. Bieniewski and H. C. Meeves.................................. 55

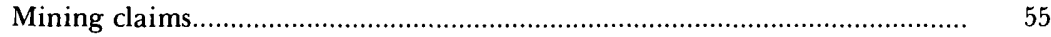

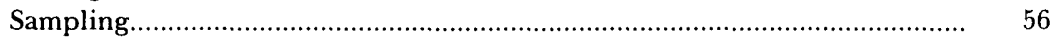

History and mineral production ........................................................... 56

Leasing act minerals................................................................................. 58

Mines, prospects, and mineralized areas.................................................. 58

Western contiguous area ....................................................................... 59

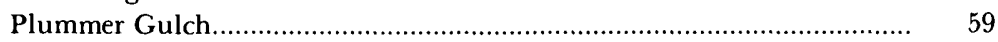

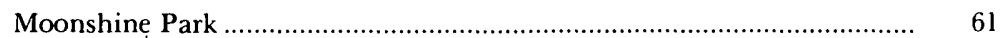

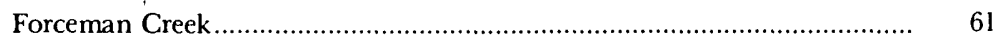

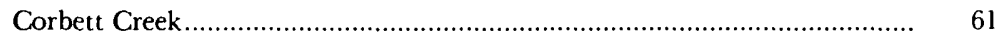

Cornet Creek-Pack Basin-Mill Creek basin ............................................. 62

San Miguel River ................................................................................. 64

Hayden Peak .................................................................................. 66

Whipple Mountain........................................................................ 66

Last Dollar Mountain ............................................................................. 66

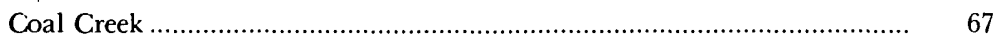

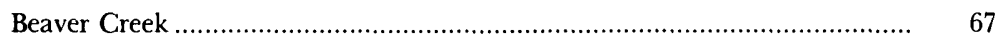

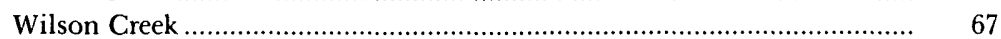

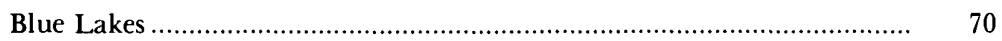

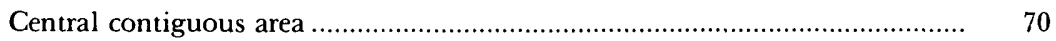

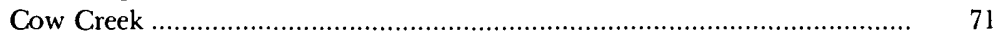

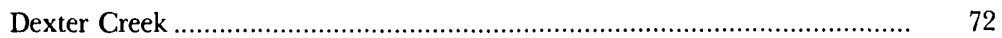

Carbonate Hill............................................................................ 74

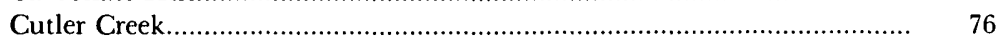

Crookéd Tree Gulch............................................................................ $\quad 79$

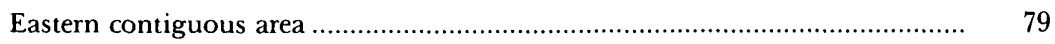

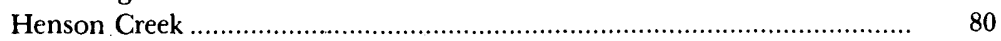

Uncompahgre Peak-Nellie Creek-Larson Creek ....................................... 83

Matterhorn Peak............................................................................. 85

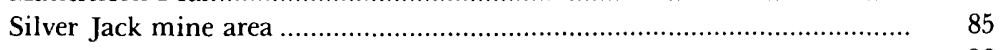

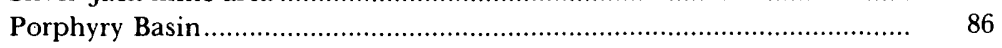

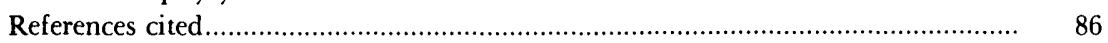

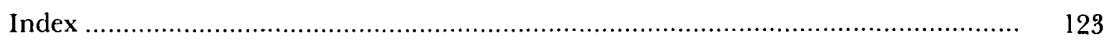

\section{ILLUSTRATIONS}

[Plates are in a separate case]

Plate 1. Geologic maps of study areas contiguous to the Uncompahgre Primitive Area, southwestern Colorado. 
Plate 2. Sample-localities maps of study areas contiguous to theUncompahgre Primitive Area, southwestern Colorado.

3. Maps showing mines, prospects, mining claims, and sample localities of study areas contiguous to the Uncompahgre Primitive Area, southwestern Colorado.

FIGURE 1. Map showing location of the study areas contiguous to the Uncompahgre Primitive Area and calderas in the San Juan volcanic field, southwestern Colorado

2. Geologic map of the western San Juan Mountains showing the Uncompahgre Primitive Area and contiguous study areas ............

3. Aeromagnetic map of the Uncompahgre Primitive Area and eastern, central, and western contiguous areas.....

4-10. Maps showing:

4. The Millersburg middle adit ................................................ 60

5. The Plummer Gulch adit ................................................ 60

6. Main underground mine workings in and near the southeastern part of the western contiguous area .................. 63

7. Adit at head of Cornet Creek ............................................... 64

8. Adit in Pack Basin ......................................................... 64

9. Adit in Mill Creek basin ............................................... 65

10. The Cowboy adit............................................................... 68

11. Aerial view of Blaine Basin............................................................ 68

12. Map of the Blaine mine ................................................................ 69

13. Map of the Hidden Silver adit ........................................................ 71

14. Map of the New York adit ............................................................

15. Aerial view of the northern end of Bighorn Ridge ......................... 73

16. Map showing major underground mine workings of the Carbonate Hill area

17. Photograph of Carbonate Hill from Little Gem mine area

18. Map of the Army-Navy adit..........

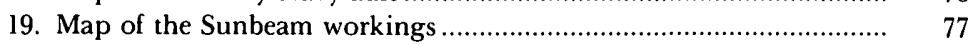

20. Photograph showing prospects in Wanakah Formation on north side of Cutler Creek.

21. Map of the Portland adit

22. Underground mine workings of the Ute-Ulay, Hidden Treasure, and Pelican mines in and near the southern part of the eastern contiguous area.

\section{TABLES}

[Tables 5-8, 11 follow "References Cited"]

TABle 1. Paleozoic sedimentary rock units in western San Juan Mountains $\ldots .$.

2. Mesozoic sedimentary rock units in western San Juan Mountains....

3. Major ash-flow sheets of the western San Juan Mountains .................

4. Selected chemical data from vein samples, western contiguous area .

5. Analyses of stream-sediment samples from the eastern contiguous area .

6. Analyses of rock samples from altered areas, eastern contiguous area 
TABLE 7. Analyses of rhyolite intrusive rocks and associated wallrocks, eastern contiguous area.

8. Uranium, thorium, fluorine, and radioactivity in rhyolite intrusives and associated rocks

9. Magnetic measurements of intrusive rocks, Uncompahgre Primitive Area and surrounding areas.

10. Magnetic measurements of volcanic flows, breccias, and welded tuffs, Uncompahgre Primitive Area and surrounding areas.

11. Analyses of samples from study areas contiguous to the Uncompahgre Primitive Area

12. Chemical analysis of limestone (sample 390) from the Pony Express Limestone Member, Wanakah Formation.

13. Analyses of coal from west of San Miguel. 


\title{
MINERAL RESOURCES OF STUDY AREAS CONTIGUOUS TO THE UNCOMPAHGRE PRIMITIVE AREA, SAN JUAN MOUNTAINS, SOUTHWESTERN COLORADO
}

\author{
By T: A. Steven, P. W. Lipman, and F. S. Fisher, \\ U.S. Geological Survey, and \\ C. L. Bieniewski and H. C. Meeves, U.S. Bureau of Mines

\section{SUMMARY}

A mineral survey was made by the U.S. Geological Survey and the U.S. Bureau of Mines of three areas contiguous to the Uncompahgre Primitive Area in southwestern Colorado; the three areas have been proposed for inclusion in the National Wilderness Preservation System. The combined area covers about 21.5 square miles ( 550 square kilometres), or about 137,000 acres $(55,500$ hectares) of rugged terrain in the western San Juan Mountains. The mineral resource potential of these areas was investigated in 1972 by two field teams from the U.S. Geological Survey and one team from the U.S. Bureau of Mines. Existing geophysical data covering the three areas were analyzed and were interpreted by the U.S. Geological Survey.

The western San Juan Mountains, including the three contiguous areas studied, consist of a deeply dissected volcanic plateau built in middle Tertiary time on a platform of slightly deformed Paleozoic, Mesozoic, and local lower Tertiary sedimentary rocks. Intrusive igneous rocks were emplaced in latest Cretaceous time, and at several times during accumulation of the volcanic rocks in middle Tertiary time. Mineralization took place during both periods of igneous activity in the Late Cretaceous and in the middle Tertiary.

Within or adjacent to the three areas studied there are 525 patented claims and 4,300 unpatented claims. Of these, 93 patented claims and approximately 3,000 unpatented claims are within the contiguous areas. All mine and prospect workings that could be found within or near the contiguous areas were examined, and most were sampled.

Important mineral deposits of several ages have been exploited at many places in the western San Juan Mountains, including the originally studied Uncompahgre Primitive Area. Although the three contiguous areas-western, central, and eastern-considered here are largely outside the more productive mining areas, some evidence exists for metallic mineralization near the margins of the areas. The potential for significant fossil fuel resources within the contiguous areas is low, although coal conceivably may exist in local structural basins beneath the northwestern part of the eastern contiguous area and oil and gas accumulations are possible beneath the northern part of the central area and northwestern part of the eastern area. Geothermal energy potential seems low, although this conclusion is based on sketchy data. 
A large quantity of "moss rock" for decorative purposes is readily available in talus piles in the western part of the western contiguous area, and it is a significant mineral resource. Stone, sand, and gravel for construction purposes could be obtained from many parts of the contiguous areas, and limestone in the Pony Express Member of the Wanakah Formation has been used for chemical purposes and is a potential resource in the central and western contiguous areas, but these commodities also occur in large volume in adjacent, readily accessible areas, where they can be obtained more economically.

The southeastern part of the western contiguous area is cut by numerous veins. Some of them are the northwestern ends of major veins that have produced significant precious and base-metal ore in the major mining area a few miles southeast, and mine maps indicate some underground workings within the western contiguous area. Other shorter veins extend into the western contiguous area from the Stony Mountain-Mount Sneffels stock which lies just to the east; some of them may contain significant metallic resources at depth. The several veins cutting the volcanic rocks between Whipple Mountain and Hayden Peak in the western part of this contiguous area indicate widespread hydrothermal activity, but the low metal concentrations measured at the surface and the weak vein structures suggest only a moderate to low economic potential.

Surface indications of hydrothermal activity are weak within the central contiguous area, but an important potential exists for buried mineral deposits. The middle Tertiary volcanic rocks at the surface unconformably overlie productive Upper Cretaceous deposits exposed along the Uncompahgre River valley near Ouray, where only the western part of a mineralized intrusive center has been uncovered by recent erosion. If the eastern side of the center is mineralized comparably to the western side, a significant potential exists under the volcanic cover between the Uncompahgre River and Cow Creek. Much of this area is in the original Uncompahgre Primitive Area and south of the central contiguous area, but productive veins are known in the Dexter Creek drainage along the southwest side of the central contiguous area, and similar veins almost certainly exist under the adjacent volcanic cover to the northeast. Other intrusive centers, possibly with related mineral deposits, may exist elsewhere beneath the volcanic cover in the central contiguous area. Such deposits would be difficult and expensive to find; thus, they may not be economic at this time. The probability that they exist is sufficiently good, however, to postulate a significant resource potential.

The intrusive center cutting volcanic rocks on Bighorn Ridge along the northern margin of the Uncompahgre Primitive Area southeast of the central contiguous area is locally altered and some samples contain anomalous concentrations of copper. This center potentially might contain a disseminated "porphyry-type" copper deposit.

Several mineralized areas occur along the southern periphery of the eastern contiguous area. These areas are in part marked by aeromagnetic lows that may be related to hydrothermally altered rock and may have economic significance. The Matterhorn volcanic center, Iron Beds altered area, and Capitol City mining area are all just outside the southwestern margin of the contiguous area; these altered and mineralized areas are associated with monzonitic intrusive bodies, and all of them have a good potential for the discovery of economic mineral deposits. Base- and precious-metal veins are known in lower Henson Creek along the south side of the eastern contiguous area, and at least two of these approach and may extend into the contiguous area. Several of these veins have produced significant metal in the past and probably contain significant undiscovered resources. The potential for future discovery of mineral deposits, however, is largely south of the eastern contiguous area, and, except for veins exploited by the Ute-Ulay, Hidden Treasure, and Pelican mines, little evidence for related mineral deposits was seen in adjacent areas to the north.

The Cimarron volcanic center in the East Fork Cimarron River drainage is partly within the eastern contiguous area. The intrusive core and adjacent wallrocks are irregularly altered, but evidence for mineral deposits is sparse. The potential for disseminated copper or molybdenum deposits within the intrusive core seems better than for significant vein deposits, but available evidence does not favor the discovery of economic deposits of either type. 
Anomalously radioactive rhyolite intrusions, which extend eastward across the southern part of the eastern contiguous area, contain at least three areas with small concentrations of secondary uranophane in fracture zones, and a few tons of uranium ore have been mined from one of these areas. Other similar concentrations may exist, and some of them may be of sufficient size to be of economic interest. Most rock appears somewhat depleted in uranium, however, and the potential for major deposits is judged to be low.

The remainder of the eastern contiguous area, embracing most of the area north of the Henson Creek drainage and east of the East Fork Cimarron River, shows only local evidence of hydrothermal activity and virtually no indication of economic mineral deposits.

\section{INTRODUCTION}

Contiguous areas aggregating 137,000 acres $(55,500$ ha (hectares)) or about 215 square miles $\left(550 \mathrm{~km}^{2}\right.$ (square kilometres)) along the north, west, and east sides of the Uncompahgre Primitive Area, southwestern Colorado, were studied as possible additions to the National Wilderness Preservation System. Part of this acreage in the drainage basins of Cow Creek and the Middle and West Forks Cimarron River was included as a marginal study area in the original investigation of the mineral potential of the Uncompahgre Primitive Area by the U.S. Geological Survey and U.S. Bureau of Mines (Fischer and others, 1968, pl. 1). During the present investigation some additional data on this area were collected by the U.S. Bureau of Mines, but no further work was done by the U.S. Geological Survey. The remaining three areas covering about 110,000 acres $(45,000$ ha) or about 170 square miles $\left(430 \mathrm{~km}^{2}\right)$ were studied by both the U.S. Geological Survey and the U.S. Bureau of Mines during 1972; these areas form the primary focus of this report and will be referred to as the western, central, and eastern contiguous areas (figs. 1, 2; pls. 1-3).

Much of the terrain of the contiguous areas is extremely rugged, and altitudes range from about 7,400 feet $(2,225 \mathrm{~m}$ (metres)) near the Uncompahgre River to over 14,000 feet $(4,300 \mathrm{~m}$ ) on Uncompahgre Peak, with at least three-fourths of the area above 10,000 feet $(3,050 \mathrm{~m})$. Access to the peripheries of these areas ranges from excellent along all-weather highways that follow the San Miguel, the Uncompahgre, and the Lake Fork Gunnison Rivers to fair or poor along secondary roads and jeep trails that extend along some secondary drainage systems. Within the contiguous areas, good trails follow most of the larger streams in the eastern area, but trails are rare and commonly poor in the central and western areas. Many of the higher ridges can be traversed only with great difficulty and considerable hazard.

Summers in the high mountains are short and cool, and thunderstorms are common. The winters are long and cold, and deep snow commonly covers the intermediate and higher areas.

The western contiguous area covers slightly more than 45 square miles $\left(115 \mathrm{~km}^{2}\right)$ in the shape of a distorted $U$, enclosing the high, sinuous, and commonly knife-edged ridge along the county line between Ouray and San Miguel Counties. Several spur ridges extend out from the main ridge 
and are separated by deep, steep-walled, glaciated canyons. The higher ridges are above timberline, and consist largely of bare or lichen-covered rock with local patches of grassy tundra. The high ridges are generally flanked by great banks of talus, and spectacular rock glaciers extend down the heads of many of the north-facing canyons. Lower slopes are covered by dense stands of spruce, pine, and aspen, broken locally by open grassy parks.

The central contiguous area in Ouray County consists of 25 square miles $\left(64 \mathrm{~km}^{2}\right)$ of tree-covered rounded mountains. Steep-walled canyons and valleys enclose Dexter, Cutler, and Cow Creeks, but the interfluve areas are more subdued than the high mountains in the Uncompahgre Primitive Area to the south. Most of the central area lies between 9,000 and 10,500 feet $(2,700$ and $3200 \mathrm{~m})$ in altitude, and none extends above timberline, which is about 11,800 feet $(3,600 \mathrm{~m})$ altitude in this area.

The eastern contiguous area includes somewhat more than 100 square miles $\left(255 \mathrm{~km}^{2}\right)$ of a highly dissected volcanic plateau lying between the Middle Fork Cimarron River and the Lake Fork Gunnison River in Hinsdale and Gunnison Counties. Steep-walled glaciated valleys flank major north-flowing streams in the northern three-quarters of this study area. Intervening ridges range from serrated, knife-edged crests in the Cimarron River drainage area to elongate flat-topped ridges between the Little Cimarron and the Lake Fork Gunnison Rivers. Within the study area most ridge crests extend above timberline, and in the southern part they include several high and spectacularly rugged mountains. The ridges diminish in altitude northward, and in the northeastern parts of the area they are densely covered by spruce forest. Open grassy parks occupy large parts of the glaciated valley bottoms.

The southern part of the eastern contiguous area is drained by numerous short precipitous south-flowing streams tributary to Henson Creek. Relief is great, and the altitudes range from near 9,000 feet $(2,700$ $\mathrm{m}$ ) along Henson Creek to 14,309 feet $(4,400 \mathrm{~m})$ on Uncompahgre Peak, the highest point along the divide a few miles north. The area above timberline is bare rock or grassy tundra, whereas the steep rocky slopes below are covered by patchy and commonly sparse spruce and aspen forest.

Commercial activities in the western San Juan Mountains include logging, grazing of sheep and cattle, recreational uses, and mining. The contiguous areas are near and partly within one of the most intensely mineralized regions of the United States, and numerous mines and prospects are present in adjacent areas and a few are within the study areas.

\section{PREVIOUS INVESTIGATIONS}

The geology of the widely mineralized western San Juan Mountains has been studied intensively for nearly a hundred years, and numerous 
maps and articles have been published. The first important summary of economic geology within the areas considered here was by Purington (1898) of the U.S. Geological Survey, who studied the ore deposits in the Telluride area near the western contiguous area. This work was followed shortly by a remarkable series of geologic folios by the U.S. Geological Survey (Cross and Purington, 1899; Cross and others, 1905; Cross and others, 1907) which established the basic geologic framework of the area. Irving and Bancroft (1911) extended the study of the ore deposits into the Lake City area to the east, near the southern margin of the eastern contiguous area.

Detailed study of the western San Juan Mountains progressed into a broader study of the whole volcanic field, directed first by Whitman Cross and later by E. S. Larsen, Jr. The results of these studies have been summarized by Cross and Larsen (1935) and Larsen and Cross (1956). Since about 1930, W. S. Burbank and several associates have studied the detailed geology of many of the more intensely mineralized areas in the western San Juan Mountains (Burbank, 1940, 1941, 1947; Burbank and Luedke, 1964, 1966, 1968, 1969; Luedke and Burbank, 1962, 1968; Kelley, 1946). The western part of the western contiguous area is within the Grayhead quadrangle that was mapped by Bush, Bromfield, Marsh, and Taylor (1961).

The mineral resource potential of the Uncompahgre Primitive Area, covering some of the most intensely mineralized area in the western San Juan Mountains, was studied in 1966 and 1967 (Fischer and others, 1968). The geology of the Wetterhorn Peak quadrangle, largely between the central and eastern contiguous areas, was mapped (Luedke, 1972) as a partial outgrowth of that study. Concurrent work in the central and eastern San Juan Mountains by T. A. Steven and P. W. Lipman established regional geologic relations (Lipman and others, 1970) that have had direct bearing on recent reinterpretations of the geologic history of the western San Juan Mountains (Lipman and others, 1973). These reinterpretations have been incorporated into the present report.

\section{PRESENT INVESTIGATIONS}

The mineral resource potential of the three areas contiguous to the Uncompahgre Primitive Area was studied by the U.S. Geological Survey and U.S. Bureau of Mines in 1972. Some additional information was collected by the U.S. Bureau of Mines on a study area previously covered (Fischer and others, 1968), but this is incorporated here in discussions of either the central or the eastern contiguous area. All pertinent published data were reviewed and the areas were studied and were sampled in the field. Data on patented mining claims were taken from records of U.S. Bureau of Land Management, and data on unpatented mining claims from records in the courthouses of Hinsdale, Gunnison, Ouray, and San Miguel Counties. 
The extent of previous study differs widely for each of the three contiguous areas, and somewhat different approaches were taken in appraising the mineral resources of each area. Studies by the U.S. Geological Survey in the western and central contiguous areas were made by F. S. Fisher, assisted by R. R. Kern. The areas were largely covered by previously published geologic maps of good quality (Bush and others, 1961; Luedke and Burbank, 1962; Burbank and Luedke, 1966; Luedke, 1972), and only minor fringe areas needed to be mapped during the current investigation. Stream sediments were sampled along all the main streams, and all altered and mineralized areas were examined and were sampled in the field.

Existing geologic maps in the eastern contiguous area, on the other hand, are all reconnaissance studies made early in the century and were inadequate for the purposes of this mineral appraisal. In consequence, the entire area was remapped by P. W. Lipman, T. A. Steven, s.nd D. A. Johnston. Concurrently, stream-sediment samples were collected along all the major streams, largely by Kimball Goddard and David Dennison, and all mineralized or potentially mineralized areas discovered in the course of geologic mapping were examined and were sampled under the direction of Steven.

All U.S. Geological Survey samples from the three contiguous areas were analyzed in Survey laboratories. Spectrographic analyses were by J. M. Motooka and J. H. Reynolds. Chemical and instrumental analyses were by C. M. Bunker, C. A. Curtis, E. J. Fennelly, W. H. Ficklin, R. L. Hutchens, A. L. Meier, J. B. McHugh, José de Mello, H. T. Millard, J. M. Negri, S. H. Truesdell, and E. P. Welsch.

U.S. Bureau of Mines studies were conducted by C. L. Bieniewski and H. C. Meeves, assisted by A. G. Hite and R. A. Van Horn. All available claim records were examined and the locations plotted where possible. All old mines or significant prospects were examined in the field, and most were sampled. Analyses were made by U.S. Bureau of Mines laboratories at Reno Metallurgy Research Center, Reno, Nev.

Only the analytical data pertinent to specific areas of special geologic interest or containing anomalous concentrations of metals are tabulated in the present report. All analytical data obtained by the U.S. Geological Survey, both tabulated and untabulated, have been placed on magnetic computer tape (Steven and others, 1973) and are available through the National Technical Information Service (NTIS), U.S. Department of Commerce, Springfield, Va. 22161, at the expense of the user. The samples are identified by the field numbers shown on plate 2; in coding and retrieval, each of these numbers carries a prefix of 72 , indicating the year the sample was collected.

\section{ACKNOWLEDGMENTS}

The cooperation of the U.S. Forest Service and U.S. Bureau of Land 
Management and many county officials, mining company personnel, and local residents is gratefully acknowledged. Special thanks are extended to Gene Adams, Dave Calhoun, Adolph Jordan, J. N. Mayor, Frank Mendenhall, Joel Swank, and Lowell Swanson for valuable information about the location and history of mines and prospects, and to Harley Greiman of the U.S. Forest Service for information on mining and prospecting activity. Art Pansze and John Longshore of Exxon Corp., Ed Hughes of Hughes Mining Co., and Bob Larsen of Baumgartner Oil Co. provided valuable information on exploration activities by their companies.

\section{GEOLOGIC APPRAISAL}

By T. A. Steven, P. W. Lipman, and F. S. Fisher, U.S. Geological Survey

Tertiary volcanic rocks predominate within the three study areas contiguous to the Uncompahgre Primitive Area and form part of the great San Juan volcanic field of southwestern Colorado (fig. 1). Some Paleozoic and Mesozoic sedimentary rocks underlying the volcanic plateau are exposed in the lower parts of the western and central areas. Hypabyssal intrusive rocks were emplaced in Late Cretaceous and middle Tertiary time, and mineral deposits are associated with intrusive centers of both ages.

The rocks exposed in the individual study areas represent only fragments of the geologic history of the area, and a coherent picture of the geology cannot be presented by considering only the specific areas studied. Instead, the general geology of the whole western San Juan Mountains area is first described, and the specific geology and mineral resources of the individual study areas are then considered within this framework.

The volcanic history of the western part of the San Juan volcanic field has recently been reinterpreted by Lipman, Steven, Luedke, and Burbank (1973) in part as a result of investigations leading to this report. Thus, the sequence of volcanic events we present here differs in certain aspects from most previously published accounts, including the report considering the mineral resource potential of the Uncompahgre Primitive Area proper (Fischer and others, 1968).

\section{REGIONAL GEOLOGY}

The western San Juan Mountains (fig. 2) have had a complex geologic history extending from Precambrian to Holocene times. No Precambrian rocks are exposed in the three study areas, and the early phases of this history will not be discussed. Paleozoic sedimentary rocks are exposed along the lower slopes above the Uncompahgre River near Ouray, along the San Miguel River near Telluride, and in small areas along Cow Creek northeast of Ouray. Mesozoic sedimentary rocks overlie the Paleozoic rocks in all these places and generally are more extensively 


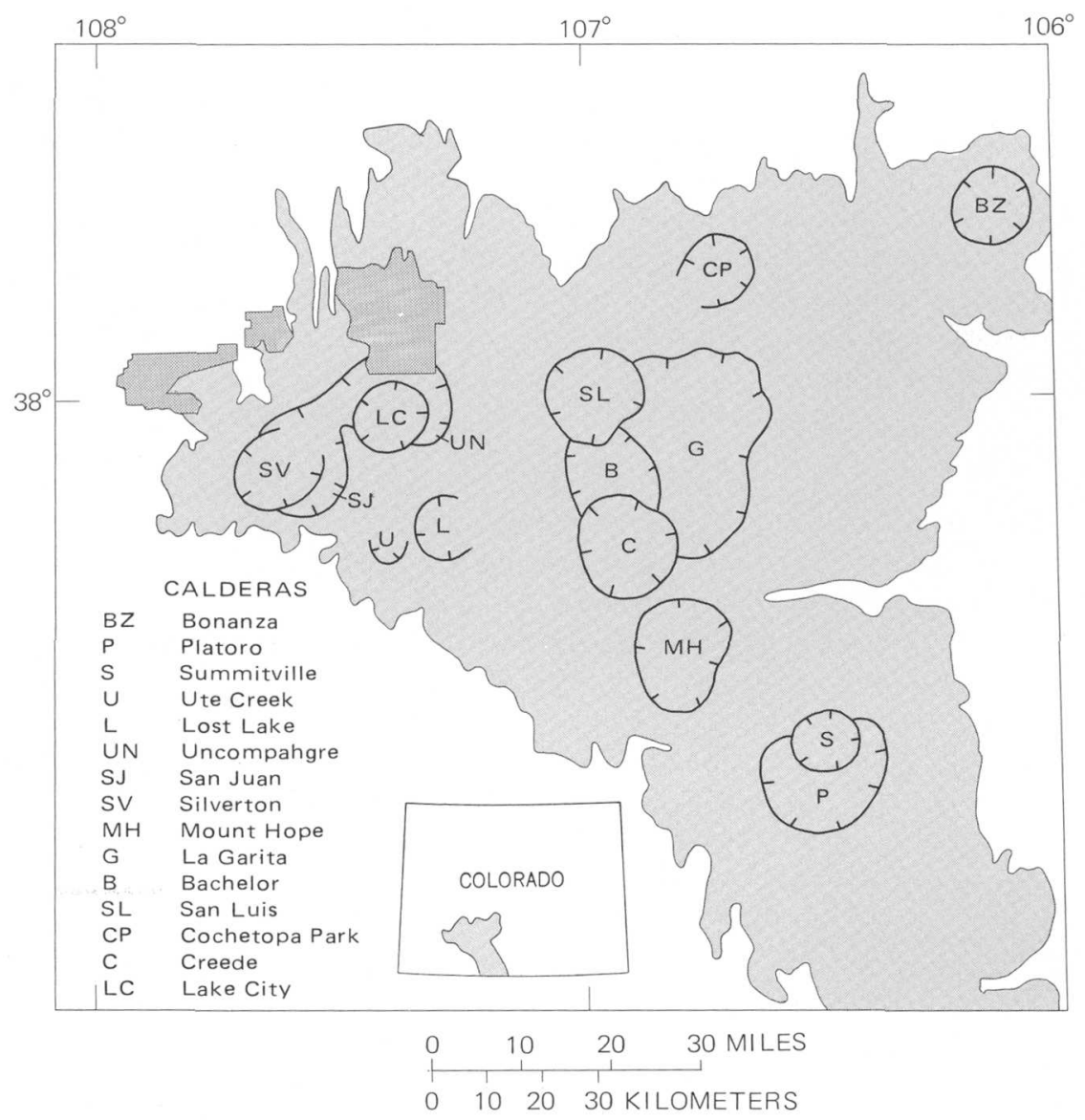

Figure 1.-Location of the study areas contiguous to the Uncompahgre Primitive area (black) and calderas in the San Juan volcanic field (stippled), southwestern Colorado.

exposed. Intrusive rocks emplaced during latest Cretaceous time cut both the Paleozoic and Mesozoic sedimentary rocks near Ouray and along Cow Creek to the northeast. Telluride Conglomerate of early Eocene age uncomformably overlies the sedimentary and intrusive rocks in places near Ouray, and much more widely between Ouray and Telluride. A thick pile of middle Tertiary volcanic rocks overlies the sedimentary and early intrusive rocks and, together with related intrusive rocks, constitutes the great bulk of the San Juan Mountains. Mineralization took place during the two periods of igneous activity, the Late Cretaceous and middle Tertiary.

\section{PALEOZOIC GEOLOGY}

The Paleozoic sedimentary rocks in the western San Juan Mountains have been described in detail by Burbank (1930, p. 157-169), and more 
recent stratigraphic usage is given by Luedke and Burbank (1962) and by Fischer, Luedke, Sheridan, and Raabe (1968, p. C7-C8). Although the Paleozoic rocks are shown as a single unit on the geologic map (pl. $1 A$ ), several formations are exposed near Ouray. The oldest of these, the Elbert Formation, is overlain successively by the Ouray Limestone, Leadville Limestone, Molas Formation, Hermosa Formation, and Cutler Formation (table 1). Of these, only the Mississippian Leadville Limestone and the Permian Cutler Formation are exposed in the central contiguous area. No rocks of Paleozoic age crop out in the eastern or western contiguous areas.

TABle 1.-Paleozoic sedimentary rock units in western San Juan Mountains

[Taken largely from Fischer, Luedke, Sheridan, and Raabe (1968) and Luedke and Burbank (1962)]

\begin{tabular}{|c|c|c|c|c|}
\hline \multirow{2}{*}{ Formation } & \multirow{2}{*}{ Age } & \multicolumn{2}{|c|}{ Thickness } & \multirow{2}{*}{ Lithology } \\
\hline & & (feet) & (metres) & \\
\hline 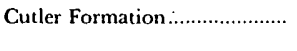 & Permian ......... & $0 \div 2,000$ & $0-610$ & $\begin{array}{l}\text { Red shale, siltstone, sandstone, } \\
\text { and conglomerate. }\end{array}$ \\
\hline Hermosa Formation................... & Pennsylvanian ...................... & $\begin{array}{l}\text { Conformable } \\
1,450\end{array}$ & 440 & $\begin{array}{l}\text { Greenish-gray or red shale, sand. } \\
\text { stone, and conglomerate with } \\
\text { some limestone. }\end{array}$ \\
\hline Molas Formation ........................ & $\begin{array}{c}\text { Pennsylvanian .................. } \\
1\end{array}$ & _Unconformity & $12 \div 18$ & $\begin{array}{l}\text { Red, gray, or green calcareous } \\
\text { shale, sandstone, and con- } \\
\text { glomerate. }\end{array}$ \\
\hline Leadville Limestone .................. & Mississippian.................... & $\begin{array}{c}180-235 \\
\text { Conformable }\end{array}$ & $55-70$ & Massive dolomitic limestone. \\
\hline Ouray Limestone ........................... & 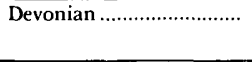 & $\begin{array}{c}70 \\
\text { Conformabl }\end{array}$ & 21 & $\begin{array}{l}\text { Thin-bedded dolomitic limestone } \\
\text { with shaly partings. }\end{array}$ \\
\hline Elbert Formation ........................ & Devonian ............................. & $30-50$ & $9-15$ & $\begin{array}{l}\text { Green, buff, or gray calcareous } \\
\text { shale, sandy limestone, and } \\
\text { sandstone. }\end{array}$ \\
\hline
\end{tabular}

The Leadville Limestone is a blue to brownish-gray fine- to coarsegrained massive dolomitic limestone. Locally, it contains thin cherty and sandy layers. In the central contiguous area it crops out only in a small area along Cow Creek (Luedke, 1972), but it ranges in thickness from 180 to 235 feet $(55-70 \mathrm{~m})$ near Ouray.

The Cutler Formation is well exposed along the Uncompahgre River valley, where it is as much as 1,200 feet $(370 \mathrm{~m})$ thick. The lower parts of the Cutler consist of interbedded red, brown, and gray fine- to coarsegrained sandstone, siltstone, and shale. In most places the beds are calcareous and in some places conglomeratic. The upper parts of the Cutler are red, pink, and gray sandstone with lesser amounts of siltstone and shale. Lenticular conglomerate beds as much as 40 feet $(12 \mathrm{~m})$ thick are scattered throughout. Clasts in the conglomerates are primarily Precambrian quartzite and other metamorphic rocks.

In late Paleozoic time the Paleozoic rocks in the western San Juan Mountains area were folded, and the area east of the Uncompahgre River was broadly uplifted and was eroded. Most Paleozoic sedimentary rocks were removed east of a sinuous, generally north-trending line that passes 1-2 miles (1.6-3.2 km (kilometres)) south and east of Ouray (Fischer and 


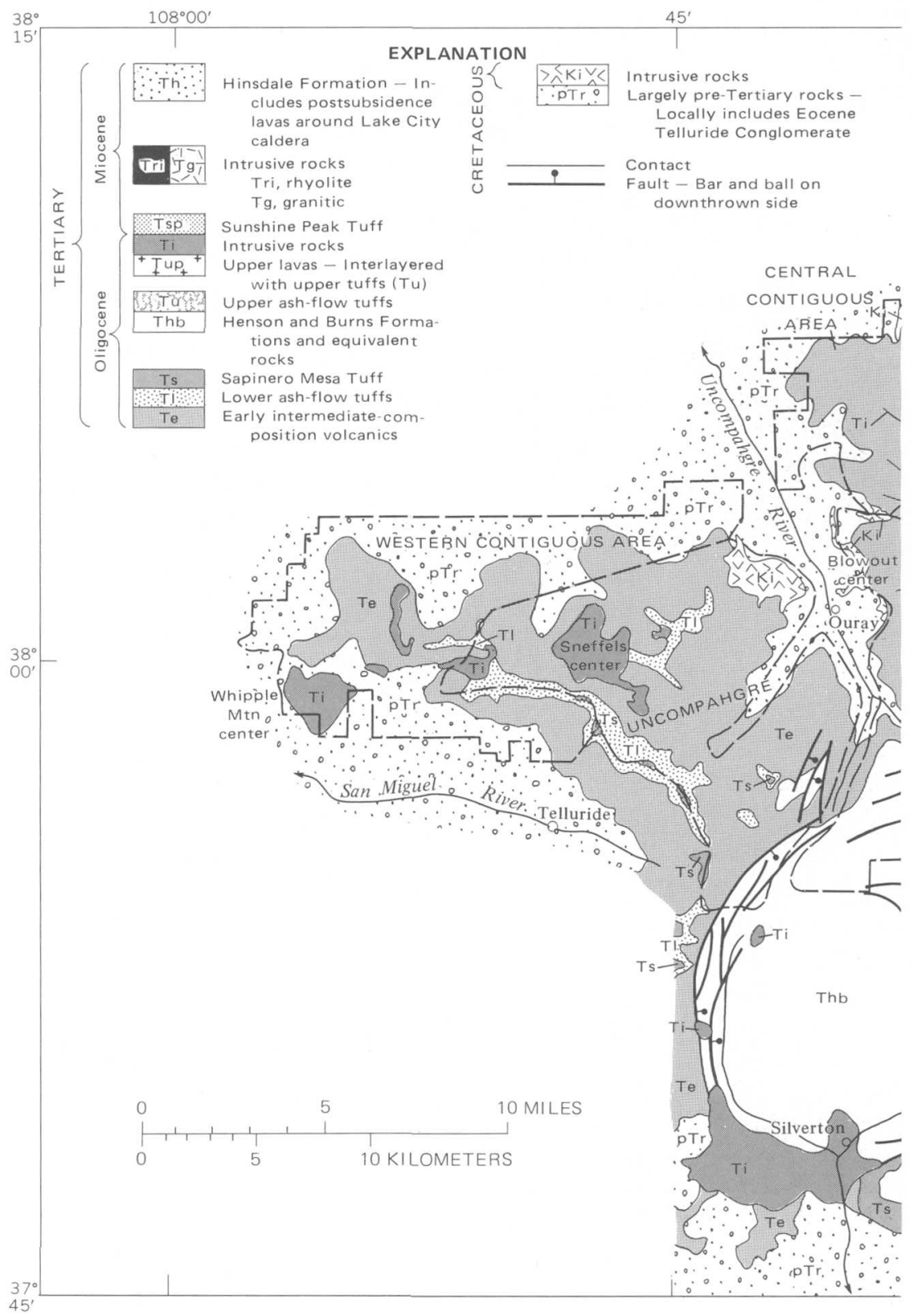

Figure 2.-Geologic map of the western San Juan Mountains

others, 1968, fig. 2). Thus, a complete section of Paleozoic strata probably underlies the western contiguous area and the western part of the central area. The units are erosionally truncated under the eastern part of the central area and probably are absent under the eastern area. 


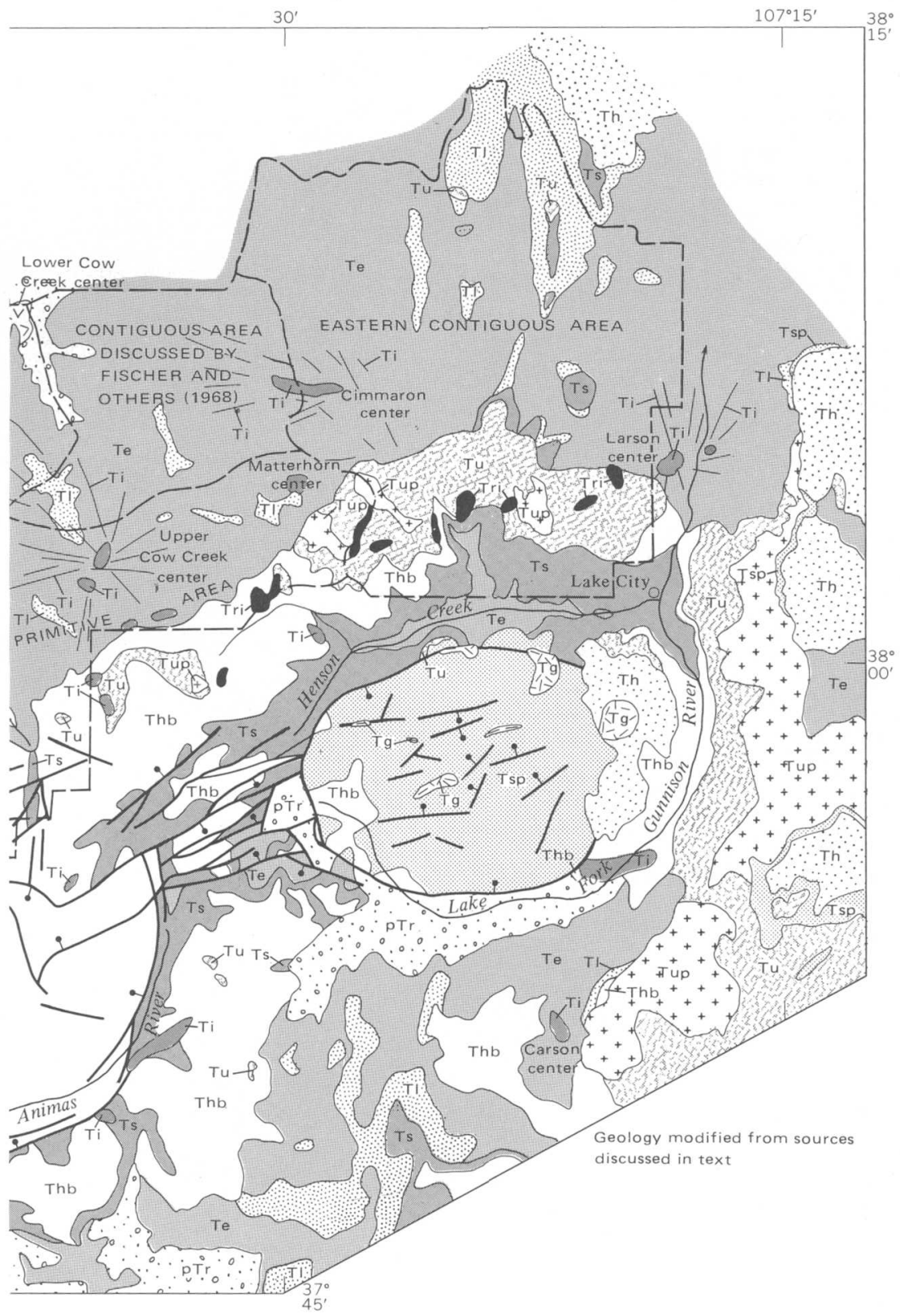

showing the Uncompahgre Primitive Area and contiguous study areas.

\section{MESOZOIC GEOLOGY}

The western San Juan Mountains area was once covered by a thick blanket of Mesozoic sedimentary rocks that ranged in age from Late Triassic to Late Cretaceous (table 2). Mesozoic rocks are now exposed only 
TABLE 2.-Mesozoic sedimentary rock units in western San Juan Mountains

[Taken largely from Fischer, Luedke, Sheridan, and Raabe (1968) and Luedke and Burbank (1962)]

\begin{tabular}{|c|c|c|c|c|}
\hline \multirow{2}{*}{ Formation } & \multirow{2}{*}{ Age } & \multicolumn{2}{|c|}{ Thickness } & \multirow{2}{*}{ Lithology } \\
\hline & & (feet) & (metres) & \\
\hline Mancos Shale ............................. & Late Cretaceous ................ & $\begin{array}{c}0-1,000 \\
\text { Conformable }\end{array}$ & $0-305$ & Gray to black shale. \\
\hline Dakota Sandstone ........................ & $\begin{array}{l}\text { Late and Early (?) } \\
\text { Cretaceous. }\end{array}$ & $40-175$ & $12-53$ & $\begin{array}{l}\text { Thin- to thick-bedded sandstone } \\
\text { with interbedded shale. }\end{array}$ \\
\hline Morrison Formation ................... & Late Jurassic.......................... & $\begin{array}{l}\text {-Unconformit } \\
620-750\end{array}$ & $\mathrm{ty}$ & $\begin{array}{l}\text { Brushy Basin Member, which is } \\
\text { predominantly variegated mud- } \\
\text { stone with subordinate sand- } \\
\text { stone and limestone, is under- } \\
\text { lain by the Salt Wash Member, } \\
\text { which is predominantly sand- } \\
\text { stone and lesser mudstone and } \\
\text { limestone. }\end{array}$ \\
\hline 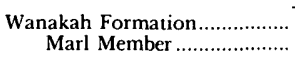 & Late Jurassic....................... & $\begin{array}{l}\text { Uncontor } \\
85-125 \\
40-75\end{array}$ & $\begin{array}{l}26-38 \\
12-23\end{array}$ & $\begin{array}{l}\text { Reddish-brown calcareous mud- } \\
\text { stone. }\end{array}$ \\
\hline $\begin{array}{l}\text { Bilk Creek Sandstone } \\
\text { Member. }\end{array}$ & & $14-25$ & $4-8$ & $\begin{array}{l}\text { Greenish-gray to buff fine- } \\
\text { grained silty sandstone. }\end{array}$ \\
\hline $\begin{array}{l}\text { Pony Express Limestone } \\
\text { Member. }\end{array}$ & & Conformable & $0.3-21$ & $\begin{array}{l}\text { Porous breccia derived by partial } \\
\text { leaching of gypsum from a } \\
\text { mixed assemblage of gypsum, } \\
\text { limestone, and shale beds. } \\
\text { Lower } 1-5 \mathrm{ft} \text { is fine-grained dark } \\
\text { limestone. }\end{array}$ \\
\hline Entrada Sandstone .................... & Late Jurassic................. & $\begin{array}{l}45-80 \\
\text { Unconformit }\end{array}$ & ty $14-24$ & Crossbedded sandstone. \\
\hline Dolores Formation .................... & Late Triassic.. & 80 & 24 & $\begin{array}{l}\text { Brownish-red mudstone and sand- } \\
\text { stone. }\end{array}$ \\
\hline
\end{tabular}

in the central and western contiguous areas. Upper Cretaceous intrusive rocks invade the Paleozoic and Mesozoic sedimentary rocks.

The Dolores Formation of Late Triassic age consists of thin-bedded to massive mudstone and fine- to coarse-grained sandstone with some thin layers of limestone and conglomerate; it typically forms steep brownishred slopes and cliffs. In the central contiguous area, the Dolores is exposed along the Uncompahgre River valley and along Cow Creek; it is not exposed in the western or eastern contiguous areas.

The Entrada Sandstone of Late Jurassic age is exposed only in steep cliffs and slopes in the central contiguous area along the Uncompahgre River valley and along Cow Creek. It is a white to buff thick-bedded finegrained commonly crossbedded calcareous sandstone, which ranges in thickness from 45 to 80 feet (14-24 m).

The Wanakah Formation of Late Jurassic age consists of three lithologic units: a lower, dark-colored limestone with interbedded gypsiferous shales (the Pony Express Limestone Member); a middle, greenishgray to buff silty to very fine grained calcareous sandstone (the Bilk Creek Sandstone Member); and an upper, thin-bedded reddish-brown limy mudstone and siltstone (the marl member). The entire formation is about 100 feet $(30 \mathrm{~m})$ thick. It is exposed only in the central contiguous area along the Uncompahgre River valley and in small areas along Cow Creek. 
The Morrison Formation of Late Jurassic age crops out on steep slopes and cliffs along the Uncompahgre River valley, Cutler Creek, and Cow Creek in the central contiguous area, and along Mill Creek in the western contiguous area. It is about 700 feet $(210 \mathrm{~m})$ thick; the lower half of the formation consists of lenticular light-colored sandstone with interbedded red mudstones and a few thin limestone beds, and the upper half is mainly varicolored mudstone with some thin sandstone and limestone beds.

The Dakota Sandstone of Early(?) and Late Cretaceous age is 40-175 feet $(12-53 \mathrm{~m})$ thick and varies locally from one to three units. The upper and lower units consist of interbedded sandstone and shale; these rocks commonly are absent or are not exposed. The middle unit is a thin- to thick-bedded light-colored fine- to coarse-grained sandstone containing some thin shale and mudstone layers and some conglomerate lenses. The formation is exposed in the central contiguous area along Cow Creek and in the Uncompahgre River valley and in the western contiguous area along Mill Creek.

The Mancos Shale of Late Cretaceous age crops out along many of the stream valleys in the western contiguous area, and in small areas along the Uncompahgre River valley and Cow Creek in the central contiguous area. The Mancos consists predominantly of gray to black shale that ranges in thickness from 0 to 1,000 feet $(0-305 \mathrm{~m})$ owing to erosion in early Tertiary time.

The area east of Ouray was again domed in latest Cretaceous (Laramide) time (Dickinson and others, 1968, p. 144-145). This renewed uplift in part reactivated older structures, but the main marginal monoclinal flexure is $2-4$ miles $(3.2-6.4 \mathrm{~km})$ northwest of the late Paleozoic monocline (Luedke and Burbank, 1962). Erosion during Late Cretaceous and early Tertiary time removed the sedimentary rocks from the higher parts of the dome. The truncated edge of Mesozoic strata forms an irregularly north-northeast-trending line that passes a few miles southeast of Telluride and Ouray and crosses the trend of the pinchout of Paleozoic rocks near the north margin of the Uncompahgre Primitive Area (Fischer and others, 1968, fig. 2). Mesozoic strata underlie all the western contiguous area, most of the central area, and at least the northwestern corner of the eastern area.

Intermediate-composition magma invaded the slightly deformed Mesozoic and Paleozoic strata in latest Cretaceous time, about $67 \mathrm{~m} . \mathrm{y}$. (million years) ago (Dickinson and others, 1968, p. 142). The largest intrusive bodies are exposed along the flanks of the Uncompahgre River valley just north of Ouray (Luedke and Burbank, 1962), and smaller bodies are known to the northeast in the drainage basins of Cow Creek and Cimarron River (Dickinson and others, 1968, fig. 2). The intrusive center of Late Cretaceous age north of Ouray consists of a crosscutting 
central stock at The Blowout, less than a mile north of town, surrounded by laccolithic and sill-like concordant sheets and by numerous smaller discordant dikes.

Dickinson, Leopold, and Marvin (1968) have shown that the Cimarron Ridge Formation exposed between the Uncompahgre and Cimarron Rivers north of the primitive area is part of a volcaniclastic apron of the same age as these intrusives. This apron was deposited north of its probable volcano source in the Ouray area. Before the Telluride Conglomerate was deposited in this area in early Eocene time, erosion removed all the near-source volcanic rocks that overlay the intrusive center near Ouray.

\section{TELLURIDE CONGLOMERATE}

Erosion of the Late Cretaceous dome in the western San Juan Mountains area stripped the sedimentary cover from this highland, and in early Eocene time (Steven and others, 1967, p. D49) an apron of coarse fluviatile depösits of the Telluride Conglomerate was deposited around the flanks of the dome. Only discontinuous tongues of coarse channel-filling deposits represent the Telluride Conglomerate near Ouray, where the marginal apron wedges out against the flanks of the dome (Luedke and Burbank, 1962). Farther from the dome near Telluride (Burbank and Luedke, 1966), however, the apron is a nearly continuous sheet, generally 100-500 feet (30-152 m) thick, of conglomerate, with interbedded sandstone, siltstone, and shale. Clasts in the Telluride Conglomerate are largely mixed Precambrian rocks with some Paleozoic and Mesozoic sedimentary rocks. The poorly sorted sandy matrix is arkosic and generally is cemented by iron-oxide stained calcite. The formation was clearly deposited before the beginning of the mid-Tertiary volcanic activity that built the overlying San Juan volcanic field.

\section{VOLCANIC GEOLOGY}

The broad aspects of the evolution of the San Juan volcanic field were summarized by Lipman, Steven, and Mehnert (1970). Volcanic activity began in latest Eocene or earliest Oligocene time, and during the interval 35-30 m.y. ago numerous widely scattered andesitic to rhyodacitic central volcanoes were built throughout south-central Colorado (Steven and Epis, 1968). The San Juan Mountains constitute the largest erosional remnant of this formerly extensive field. Between 30 and 26 m.y. ago, dominant activity in the San Juan Mountains area was voluminous quartz latitic and rhyolitic ash-flow eruptions, with associated caldera collapses at most of the eruptive centers. During the period of ash-flow eruptions, mafic-intermediate lavas and breccias continued to be erupted in reduced volume from local central volcanoes and more silicic lavas were erupted in and adjacent to the calderas. In early Miocene, about 25 m.y. ago, volcanic activity shifted from the andesitic and derivative rocks, 
which characterized the Oligocene eruptions, to a bimodal assemblage of basalt and high-silica alkali rhyolite, which was erupted intermittently through Miocene and Pliocene time. These later rocks formed a widespread but relatively thin cover of predominantly basaltic rocks, with local accumulations of rhyolite. Most of the rhyolite masses are small, but one large-volume ash-flow sheet was erupted from the Lake City caldera source (fig. 1) in the western San Juan Mountains.

\section{EARLY INTERMEDIATE VOLCANICS}

The western San Juan Mountains, in the vicinity of the Uncompahgre Primitive Area and contiguous areas, were the site of a cluster of andesitic central volcanoes (Lipman and others, 1973). Near the individual vents, these volcanoes consist of complex assemblages of lavas and breccias that stood topographically above the surrounding terrane. The near-source lavas and breccias (near-source facies) (pl. 1) intertongue laterally with widespread coalescing volcaniclastic aprons of mudflow and conglomerate debris (volcaniclastic facies) (pl. 1) derived from the central volcanoes. The surface of the outflow apron formed a widespread constructional plain, surmounted by local hills that generally represented thick local lava flows, and incised here and there by stream channels.

Diverse formational names have been assigned to different parts of these generally equivalent early intermediate volcanic rocks. Most of the outflow sheet has been assigned to the San Juan Formation, although some similar rocks to the east have been included in the Lake Fork Formation (Larsen and Cross, 1956, pl. 1). Vent-facies lavas and breccias north of Lake City form the bulk of the Lake Fork Formation (Larsen and Cross, 1956); these were derived from two adjoining central volcanoes; one west of the Lake Fork Gunnison River about 3 miles $(4.8 \mathrm{~km})$ north of Lake City, and the other about 6 miles $(9.7 \mathrm{~km})$ farther northeast. The center north of Lake City is along lower Larson Creek, just outside the eastern contiguous area (pl. $1 A$ ).

At least two other early intermediate volcanoes, defined by thick local near-source accumulations, were centered near the head of Wetterhorn Creek and in the upper drainage basin of the Cimarron River (pl. 1A). A volcanic neck that may mark the core of the Cimarron Volcano (Lipman and others, 1973) extends from the East Fork Cimarron River at the Silver Jack mine west across a high ridge into Porphyry Basin, tributary to the Middle Fork Cimarron River. Numerous dikes cut the complex ventfacies lavas and breccias surrounding this center. Present data permit an alternative interpretation, however, that these intrusions mark the roots of a younger volcano superimposed on the flank of Cimarron Volcano(D. A. Johnston, written commun., 1973).

ASH-FLOW TUFFS AND ASSOCIATED ROCKS

Initial large-volume ash-flow eruptions in the western San Juan Mountains area deposited the Ute Ridge and Blue Mesa Tuffs (Lipman and 
others, 1973; Olson and others, 1968), which spread widely over the early intermediate volcaniclastic constructional plain. These units are as much as $600-1,000$ feet $(180-300 \mathrm{~m})$ thick in places, and they originally had minimum volumes on the order of 100 cubic miles $\left(400 \mathrm{~km}^{3}\right.$ ) (table 3 ). They wedge out laterally against the volcanic highlands formed by the clustered early intermediate central volcanoes. The sources for both the Ute Ridge and Blue Mesa Tuffs were in the upper Rio Grande drainage basin, about 15 miles $(24 \mathrm{~km})$ southeast of the Uncompahgre Primitive Area-the Ute Ridge came from the Ute Creek caldera south of the Rio Grande, and the Blue Mesa came from an inferred source in the Lost Lake caldera north of the Rio Grande (fig. 1). Lipman, Steven, and Mehnert (1970, table 3, No. 10) gave a somewhat discordant age of $28.4 \mathrm{~m}$.y. for the Ute Ridge Tuff (which they called tuff of Storm King Mountain); the younger Blue Mesa Tuff was erupted shortly thereafter, as several other ash-flow sheets intervene between it and the 27.8-m.y.-old Fish Canyon Tuff (Lipman and others, 1970, table 3; Lipman and others, 1973, table 2).

Ash-flow eruptions from the vicinity of the Uncompahgre Primitive Area and contiguous areas began with the Dillon Mesa Tuff (Olson and others, 1968), which appears to have been derived from the Uncompaghre caldera areas west of Lake City. The Dillon Mesa Tuff was deposited widely in the northwestern San Juan Mountains, but it is generally less than 100 feet $(30 \mathrm{~m})$ thick - commonly less than 30 feet $(9 \mathrm{~m})$ thick-and it is nearly an order of magnitude less voluminous than the Ute Ridge and Blue Mesa Tuffs (table 3). Indirect evidence suggests that eruption of the Dillon Mesa Tuff may have caused initial collapse of the Uncompahgre caldera (Lipman and others, 1973).

The Sapinero Mesa Tuff had an original volume of more than 250 cubic miles $\left(1,000 \mathrm{~km}^{3}\right)$ and when emplaced it covered most of the western and northern parts of the San Juan volcanic field. Its eruption resulted in major collapse of both the Uncompahgre and San Juan calderas (figs. 1, 2), which localized most subsequent volcanic and related activity in the western San Juan Mountains. The mineralization that deposited most of the ores that have been mined from this highly productive area was controlled largely by structures initiated during this cycle of caldera development.

Outflow Sapinero Mesa Tuff is generally 200 feet $(60 \mathrm{~m})$ thick or less, and it wedges out laterally against the flanks of the early intermediatecomposition central volcanoes centered in upper Cimarron River drainage and areas to the south. The intracaldera Eureka Member of the Sapinero Mesa Tuff, on the other hand, is locally as much as 2,000 feet $(610 \mathrm{~m})$ thick and covers irregular topography on top of vent-facies, early intermediate-composition rocks. Lithic debris is common in the Eureka Member, and landslide debris interleaves marginally near the steep caldera walls. These relations are interpreted (Lipman and others, 1973) to indicate accumulation concurrent with caldera subsidence, in which 


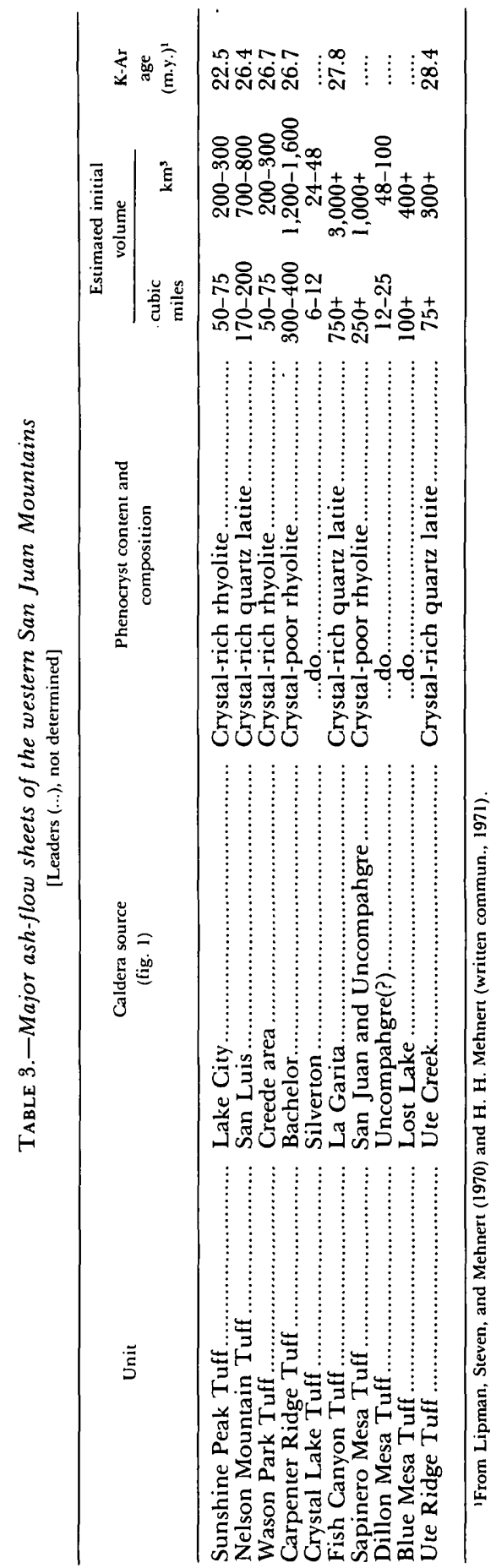


two calderas collapsed within an area of clustered early intermediatecomposition central volcanoes.

After caldera collapse, the subsided areas were filled with a complex accumulation of intermediate lavas, breccias, and volcanic sediments. Within the San Juan caldera, these rocks are subdivided into the Burns Formation, consisting of thick porphyritic rhyodacitic to rhyolitic lava flows and minor sediments, and into the overlying Henson Formation, consisting of abundant sedimentary rocks in association with more mafic andesites and rhyodacites. These distinctions have not been recognized within the Uncompahgre caldera. Equivalent mudflow breccias and local interlayered lavas overlie the outflow Sapinero Mesa Tuff east and southeast of the San Juan caldera (Lipman and others, 1973), but they have not been recognized elsewhere around the periphery of the calderas.

The Uncompahgre and San Juan calderas were resurgently domed together, apparently over an extended period of time beginning shortly after subsidence and continuing during and after accumulation of the Burns and Henson Formations and equivalent caldera-filling rocks (Lipman and others, 1973). A broad, low dome extends from the east side of the Uncompaghre caldera near Lake City, across the septum of Precambrian rocks between the calderas, to the west side of the San Juan caldera northwest of Silverton. A northeast-trending apical graben formed along the crest of the dome and involves rocks from the Burns and Henson Formations and from some of the younger ash-flow units.

Beginning with eruption of the Fish Canyon Tuff (table 3), the central San Juan Mountains became a major source area for ash-flow deposits. The distal parts of four ash-flow sheets from the central San Juan Mountains extend into the caldera area in the western San Juan Mountains, where they were in part confined to the moat around the resurgently domed core. Present remnants occur only around the eastern and northern margins of the Uncompaghre caldera and northeastern margin of the San Juan caldera. The oldest of these units is the Fish Canyon Tuff, derived from the La Garita caldera source 35 miles $(55 \mathrm{~m})$ southeast of the study area, which has been well-dated as 27.8 m.y. old (Lipman and others, 1970, table 1). This is overlain successively by the Carpenter Ridge Tuff from the Bachelor caldera, the Wason Park Tuff from a postulated source beneath the Creede caldera (Ratté and Steven, 1967, p. H34), and the Nelson Mountain Tuff from the San Luis caldera. All these units are older than the Fisher Quartz Latite of the Creede area, which has been dated as 26.4 m.y. (Steven and others, 1967).

The Crystal Lake Tuff, which intervenes locally between the Fish Canyon and Carpenter Ridge Tuffs, appears to have been erupted from the Silverton caldera, nested within the older San Juan caldera (figs. 1, 2) (Lipman and others, 1973). Ring fractures active at this time offset the Burns and Henson Formations and bound a tilted, trapdoor-style subsided block that sank 2,000 feet $(610 \mathrm{~m})$ or more on its south and southeast 
sides, but the block had virtually no displacement along its northern margin. Numerous intrusive bodies, ranging from minor dikes and plugs to a large monzonite stock, were emplaced along the late ring-fracture zone (fig. 2).

Local accumulations of intermediate-composition flows, breccias, and minor sedimentary rocks are interlayered at one place or another between all units in the late ash-flow sequence. The largest of these in the vicinity of the eastern contiguous area underlies Uncompahgre Peak and adjacent areas where a succession of thick intermediate-composition flows as much as 1,300 feet $(400 \mathrm{~m})$ thick intervenes between the Carpenter Ridge and Nelson Mountain Tuffs (pl. $1 A$ ). These rocks are believed to represent marginal accumulations erupted late in the cycle of development of the Uncompahgre caldera.

The Sunshine Peak Tuff, the youngest major ash-flow sheet in the San Juan volcanic field, was erupted about 22.5 m.y. ago from a source in the Lake City caldera area (Mehnert and others, 1972). The Sunshine Peak Tuff is a high-silica alkali rhyolite and is a typical silicic member of the bimodal basalt-rhyolite suite that characterizes Miocene and Pliocene volcanics in the San Juan field and elsewhere in the Western United States (Christiansen and Lipman, 1972).

The Sunshine Peak Tuff is more than 3,200 feet $(1 \mathrm{~km})$ thick within the Lake City caldera, where it contains abundant andesitic lithic rock fragments and interleaved andesitic landslide breccia derived by caving of the caldera walls concurrently with deposition of the ash. Remnants of the outflow sheet, in contrast, are generally less than 150 feet $(45 \mathrm{~m})$ thick and contain few fragments. These remnants are now limited to the south and east sides of the Lake City caldera, where they have been protected from erosion by hard overlying basalt flows.

The core of the Lake City caldera was resurgently domed; and coarsely porphyritic quartz latitic lavas were erupted in places around the periphery. A northeast-trending chain of rhyolite porphyry plugs, dikes, sills, and laccoliths that closely resemble the Sunshine Peak Tuff in composition were emplaced north of the structural boundary of the Lake City caldera, across the southern part of the eastern contiguous area.

\section{GLACIAL DEPOSITS}

Glaciers occupied all the main stream courses in the western San Juan Mountains during Quaternary time, and all the larger valleys in and near the three contiguous areas are in part floored by glacial drift or related sand and gravel deposits. Postglacial alluvium is restricted in most places to narrow strips adjacent to the modern streams.

\section{MINERAL RESOURCES}

The western San Juan Mountains area has been a prolific source of valuable minerals, and at present it is among the most active mining areas 
in Colorado. Metallic mineral deposits formed during periods of igneous activity in the Late Cretaceous (Laramide) and middle Tertiary, and several separate episodes of mineralization have been recognized within the latter period. Hot springs are present at several places in the San Juan Mountains and may indicate some potential for a thermal energy resource. Significant deposits of coal exist just north of the Uncompahgre Primitive Area and contiguous study areas, and oil or gas accumulations are possible within the same general area.

\section{LATE CRETACEOUS MINERALIZATION}

The intrusive center (The Blowout) of Late Cretaceous age north of Ouray (fig. 2) was a major center of mineralization. Some of the intrusive bodies are intensely altered and are pyritized, and fractures cutting the surrounding Paleozoic and Mesozoic strata contain base and precious metals (Burbank, 1940). The ore deposits formed in part as fracture-filling veins in the harder sandstone units, and in part as replacement bodies in the more reactive rocks adjacent to such fractures. Mesozoic rocks, particularly those in the Pony Express Limestone Member of the Wanakah Formation and in the Dakota Sandstone, are hosts for the larger ore bodies developed to date. Total production to 1940 was about $\$ 12$ million (Burbank, 1940, p. 193); an estimated $\$ 1$ million has been produced since then.

\section{MIDDLE TERTIARY MINERALIZATION}

At least three episodes of mineralization can be recognized in the Tertiary volcanic sequence of the western San Juan Mountains. The oldest of these is associated with the intrusive cores of two or three early intermediate-composition volcanoes around the periphery of the Uncompahgre caldera. Of these, the Larson and Cimarron centers are north of the caldera (fig. 2) and are either in or immediately adjacent to the eastern contiguous area. The third center is at the old mining camp of Carson (Larsen, 1911), south of the caldera, where production in the early days of mining is estimated to have been about $\$ 200,000$ (Vanderwilt, 1947, p. 115). The Larson and Cimarron centers are widely altered and are prospected, but little if any production has been recorded. Geochemical sampling connected with the present study disclosed only weak anomalies around the Larson and Cimarron centers.

Ores deposited in fractures initiated during the San Juan, Uncompahgre, arid Silverton caldera cycles (Steven and others, 1974) have supplied most of the production from the western San Juan Mountains. Numerous intermediate to silicic intrusive bodies cut the caldera fills, and they are especially abundant along the ring-fracture zone of the Silverton caldera (figs. 1, 2). Many of these intrusive bodies are altered and are mineralized, and nearby fractures commonly contain metalliferous veins. The Red Mountain district in the south-central part of the Uncompahgre 
Primitive Area (Fischer and others, 1968, p. C25) was the center of especially intense alteration and mineralization, and a series of persistent major veins extends northwestward across the western part of the primitive area toward Mount Sneffels. These veins have been the most productive in the western San Juan Mountains area, and the veins supply most of the ore currently being mined in the area (Fischer and others, 1968, p. C24). The distal parts of some of these veins extend into the western contiguous area. Other veins deposited in and near the Uncompahgre Primitive Area occur along the crest of the resurgent dome that jointly uplifted the cores of the Uncompahgre and San Juan calderas late in the caldera cycles. Local intrusive centers emplaced within and adjacent to the northern parts of the Uncompahgre and San Juan calderas also were more or less latered and are surrounded by mineralized areas containing metalliferous veins along fractures. The veins are most abundant in the Engineer Mountain-Red Mountain Creek area within the Uncompahgre Primitive Area (Fischer and others, 1968, p. C29) and along the north side of the Uncompahgre caldera between Henson Creek and the south boundary of the eastern contiguous area (pl. 1A). The Matterhorn intrusive center, within the eastern contiguous area (fig. 2), is the locus of intense hydrothermal alteration, and stream-sediment and bedrock samples contain anomalous concentrations of several metals.

Alteration and mineralization associated with the Lake City caldera are represented by Red Mountain, an intensely altered quartz latite lava dome that passes downward into a volcanic neck. This dome was emplaced along the eastern ring fracture of the caldera, about 3-4 miles $(4.8-6.4 \mathrm{~km})$ south of Lake City; it is younger than the Sunshine Peak Tuff, and older than adjacent quartz latitic lavas in the moat of the Lake City caldera, both of which have been dated as about 22.5 m.y. old (Mehnert and others, 1973). In addition, many of the distentional fractures cutting Sunshine Peak Tuff in the resurgently domed core of the Lake City caldera are extensively altered, and sulfide-bearing veins follow some of these. The east-trending chain of rhyolite intrusives emplaced north of Henson Creek following the Lake City caldera cycle are anomalously radioactive, and in places contain small concentrations of supergene uranium minerals.

\section{GEOTHERMAL ENERGY}

Thermal springs are widely scattered through the San Juan Mountains (Pearl, 1972, p. 18-23). The best known near the Uncompahgre Primitive Area and contiguous study areas are the Radium (Ouray) Hot Springs at Ouray (temperatures $60^{\circ}-82^{\circ} \mathrm{C}$ ), and the Orvis (Ridgway) Hot Spring 2 miles $(3.2 \mathrm{~km})$ west of the northwest corner of the central contiguous area (temperature $54^{\circ} \mathrm{C}$ ). Other thermal springs in adjacent parts of the western San Juan Mountains are the Cebolla (Powderhorn) Hot Springs, 15 miles $(24 \mathrm{~km})$ northeast of the eastern contiguous area (temperatures 
$\left.9^{\circ}-46^{\circ} \mathrm{C}\right)$, and the Lemon Hot Springs at Placerville, 5 miles $(8 \mathrm{~km})$ west of the western contiguous area (temperature $34^{\circ} \mathrm{C}$ ). As reported by Pearl (1972, p. 12, 44), a heat-flow measure made at Ouray by E. R. Decker in 1969 was 3.7 heat-flow units (a heat-flow unit is $1.0 \times 10^{-6} \mathrm{cal} / \mathrm{cm}^{2}$ sec); this measurement is the highest that has been reported from interior of the earth of 1.5 heat-flow units. These springs thus reflect somewhat higher than normal heat flow beneath the San Juan region, and possibly a potential source of geothermal energy.

Most areas of developed geothermal energy utilize natural steam, or very hot water capable of flashing into steam on release of pressure. These areas occur in regions of late Tertiary or Quaternary igneous activity where abnormally hot volcanic or intrusive rocks lie close to the surface (White, 1965, p. 10; Godwin and others, 1971, p. 7). Permeable reservoir rocks also are essential to permit ready transfer of heat by circulating fluids rather than by conduction through rock. An impermeable cap above the reservoir favors retention of heat and permits buildup of pressures; therefore, supercritical conditions can exist. Very hot but dry rocks near the surface are a potential energy source if proper technology is developed to utilize the heat.

None of these favorable conditions is known to exist in the western San Juan Mountains. Precambrian crystalline rocks underlie well-compacted Paleozoic and Mesozoic sedimentary rocks at fairly shallow depths, so the capacity of potential reservoirs is limited. The general requirement of hot near-surface rocks is generally met in areas where igneous activity took place within the last few million years, but in the western San Juan Mountains the most recent volcanic activity that has been dated is about 18 m.y. old (H. H. Mehnert, written commun., 1972). Thus, it would seem that the geothermal energy resource potential of the Uncompahgre Primitive Area and contiguous study areas is low, although present data are too sparse for a definite statement to be made.

\section{FOSSIL FUELS ${ }^{1}$}

The Tongue Mesa coal field underlies the general Cimarron Ridge area from about 5 miles $(\mathrm{k} \mathrm{km})$ northwest of the northwestern corner of the eastern contiguous area, northward for about 15 miles $(24 \mathrm{~km})$. The coal is in the lower 200 feet $(60 \mathrm{~m})$ of the Fruitland Formation, which overlies the Pictured Cliffs Sandstone and Mancos Shale and underlies the Kirtland Shale, all of Late Cretaceous age. The coal is subbituminous, and its aggregate thickness is as much as $40-50$ feet $(12-15 \mathrm{~m})$ in places. It has been widely drilled in recent years, and commercial development is contemplated.

'Data supplied largely by R. G. Dickinson, U.S. Geological Survey. 
The coal field is terminated on the south by the Ridgway fault, which crosses the Uncompahgre River 10 miles $(16 \mathrm{~km})$ north of Ouray and swings northeast to pass 5 miles $(8 \mathrm{~km})$ northwest of the northwestern corner of the eastern contiguous area. The uplifted block south of the fault is widely covered by younger volcanic rocks and by glacial and landslide debris; thus, geologic relations are obscure. Most scattered exposures are of Mancos Shale, but widely different faunal zones are juxtaposed in such a manner as to suggest that the area is complexly faulted. Two small areas of probable Fruitland Formation are exposed through the widespread landslide and glacial drift cover in the Cimarron River valley southeast of the Ridgway fault, indicating the possibility that some coal may exist in local fault blocks in this area as well. One of these exposures is only 2 miles $(3.2 \mathrm{~km})$ from the northwest corner of the eastern contiguous area.

Inasmuch as this faulting took place during the Laramide orogeny in latest Cretaceous and early Tertiary time, the surface geology of the midTertiary volcanic rocks exposed in the eastern contiguous area gives no clue to the buried structure that might control the distribution of coalbearing rocks. Available evidence does not indicate the presence of any coal beneath the eastern study area, but on the other hand, if suitable downdropped blocks are present in the pre-Tertiary basement, buried areas containing significant resources of coal could well exist.

The Dakota Sandstone is a common reservoir rock for oil and gas accumulations throughout the Southern Rocky Mountains region. This formation underlies most of the western and central contiguous study areas and at least the northwestern part of the eastern contiguous area. Any area within or adjacent to the study area underlain by Mancos Shale or by the Fruitland Formation would in all probability be underlain by Dakota Sandstone as well. The probable faults indicated by juxtaposed faunal zones in the Mancos Shale just northwest of the eastern contiguous area would offset the underlying Dakota Sandstone.

Small quantities of natural gas have been discovered in the Dakota Sandstone in the Ridgway field (Parker, 1962, map 1 in pocket) on the east side of the Uncompahgre River valley, 2.5 miles $(4 \mathrm{~km})$ north of the northwest corner of the central contiguous area. Depending on the presence of suitable structural or stratigraphic traps to retain hydrocarbons, concentrations of oil or gas in potentially economic quantities could well exist at one place or another in any area underlain by the Dakota Sandstone. Possible exceptions are areas near the igneous centers exposed at many places in and near the contiguous areas, where heat and metamorphism accompanying intrusion would make accumulation of oil or gas unlikely.

No resources of oil and gas within the study areas contiguous to the Uncompahgre primitive Area can be postulated from known data, but the possibility that such resources may exist must be recognized. 


\section{WESTERN CONTIGUOUS AREA}

\section{GEOLOGY}

The western study area contiguous to the Uncompahgre Primitive Area (pl. $1 B$ ) consists largely of a high ridge of volcanic and intrusive rocks set on a platform of low-dipping Mesozoic sedimentary rocks. A layer of Eocene Telluride Conglomerate at the base of the ridge intervenes between the older sedimentary rocks and the volcanic rocks. Great landslides form the northern flank of the ridge, and over most of the area they cover the contact between the volcanic and sedimentary rocks.

The sedimentary platform beneath the western contiguous study area is capped nearly everywhere by the Mancos Shale, which forms smoothly rounded topography above the more precipitous slopes on the harder, underlying Dakota Sandstone. Dips in the sedimentary rocks are low, generally $5^{\circ}$ or less, along the western and northern margins of the western contiguous area. On the south side, dips steepen to $20^{\circ}-30^{\circ} \mathrm{W}$. on the limb of a monocline in the vicinity of Mill Creek but flatten to near $5^{\circ}$ W. farther east near Telluride. The Mancos Shale is structurally weak and was a favored host for concordant and semiconcordant sills and laccolithic intrusives.

The arkosic Telluride Conglomerate unconformably overlies the Mancos Shale. It is a hard, resistant unit that commonly stands as steep slopes and cliffs. Significant bodies of base- and precious-metal replacement ore are being mined in the Telluride Conglomerate in the highly productive mining area a few miles east of the western contiguous area (Mayor and Fisher, 1972).

The San Juan Formation is a local outflow volcaniclastic apron that surrounded the clustered early intermediate-composition volcanoes in the western San Juan Mountains. The San Juan Formation forms the main part of the volcanic ridge in the western contiguous area and stands as rubbly cliffs as much as 2,000 feet $(600 \mathrm{~m})$ high. Great banks of talus at the base of the cliffs commonly obscure relations with underlying rocks. The formation consists mainly of mudflow breccias, water-laid tuffs, and conglomerates that were derived from the central volcanoes. Near the San Juan caldera these rocks were intensely propylitized, and the originally fragmental unit was converted into a more uniform, compact greenish rock that acted as a competent host for the fracture-filling veins that to the east of this study area have supplied much of the metal production.

Ash-flow units form a thin, discontinuous cap to the high volcanic ridge in the western contiguous area. Many veins and dikes cut these rocks, but the tuffs have not been hosts for economic ore deposits farther east.

Intrusive rocks cut the sedimentary and volcanic rocks at many places in the western contiguous area. A large, semiconcordant body of granodiorite was emplaced in the northeastern part of the western 
contiguous area in Late Cretaceous time. This floored laccolithic body was injected westward from the intrusive center at The Blowout, north of Ouray, into the sedimentary section just above the contact between the Dakota Sandstone and Mancos Shale. It was unroofed by erosion in early Tertiary time, and it was covered unconformably by the San Juan Formation in Oligocene time.

Intrusions emplaced during middle Tertiary volcanism are common in the western contiguous area; these range in composition from rhyolite to gabbro, but porphyritic andesite and granodiorite predominate. A major stock of this age centers on Mount Sneffels within the original Uncompahgre Primitive Area (fig. 2), and several similar discordant bodies cut the volcanic ridge farther west. A major laccolithic body was emplaced in the Mancos Shale at Whipple Mountain at the west end of the high ridge. Many thin sills were injected into the Mancos Shale adjacent to the laccolith at Whipple Mountain, and numerous steeply dipping dikes cut the sedimentary and volcanic rocks throughout the western and southern parts of the western contiguous area.

\section{STREAM-SEDIMENT SAMPLES}

Stream-sediment samples were taken along all the main streams draining the western contiguous area (pl. $2 B$ ). Because of the difficulty of access, the streams were best sampled near the margins of the study area, but the streams are short and precipitous and the samples collected should reflect in some measure the headwaters areas as well. Analytical results from these samples were largely negative and are not tabulated.

Except for streams draining areas with known mines and mineralized veins (samples F178 and F181 from Wilson Creek, and F276 from a tributary to Mill Creek in Pack Basin, pl. 2B), most analytical results indicate background metal concentrations only. The most significant exception was a widespread, relatively low anomaly (5-10 ppm) of molybdenum in samples collected near the contiguous area boundary where the streams flow through Mancos Shale. Dark shales in general are slightly enriched in many metals (Vine and Tourtelot, 1970), and the Mancos Shale probably supplied most of the molybdenum detected in these samples.

One sample (F112) from a tributary of Coal Creek contained $300 \mathrm{ppm}$ (parts per million) zinc, and another (F288) from a tributary of Alder Creek contained $0.5 \mathrm{ppm}$ silver. No other elements in either sample were present in anomalous concentrations, and no other samples nearby had more than background concentrations. In the absence of more supporting data, the significance of these scattered anomalous values cannot be assessed.

\section{VEIN DEPOSITS}

All veins seen in the western contiguous area are of middle Tertiary age. The most highly mineralized of these, along the volcanic ridge near 
Greenback Mountain and Mount Emma (pl. 1B), are the distal ends of major radial veins that trend northwest out of the Silverton and San Juan calderas (Burbank and Luedke, 1968), and they extend into the southeastern part of the western contiguous area. Several of these veins, such as the Smuggler-Union, Liberty Bell, Terrible, and Humboldt (Burbank and Luedke, 1966), were the source of significant base- and preciousmetals production in the major mining area just southeast of the contiguous area. Samples from some of these veins (F216-F226, table 4), taken along the crest of the volcanic ridge ( $\mathrm{pl} .2 B$ ), contain anomalous concentrations of silver, arsenic, gold, copper, mercury, molybdenum, lead, antimony, and zinc, although no ore-grade material was indicated. The grade and tonnage of mineralized rock at depth along these veins beneath the western contiguous area cannot be estimated from present exposures, but the surface evidence for mineralization and the known existence of ore at depth to the southeast suggest that ore-grade material may be present.

TABLE 4.-Selected chemical data from vein samples, western contiguous area [See pl. $2 B$ for sample localities. ppm, parts per million; $N$, not detected; L, detected but below lower limit of measurement. Number in parentheses below element symbol is the usual lower limit of determination]

\begin{tabular}{|c|c|c|c|c|c|c|c|c|c|}
\hline \multirow{2}{*}{ Sample } & \multicolumn{2}{|c|}{$\begin{array}{c}\text { Semiquantitative } \\
\text { spectrographic analyses } \\
\text { (ppm) }\end{array}$} & \multicolumn{7}{|c|}{$\begin{array}{l}\text { Chemical analyses } \\
(\mathrm{ppm})\end{array}$} \\
\hline & $\begin{array}{c}\mathrm{Ag} \\
(0.5)\end{array}$ & $\begin{array}{l}\text { Mo } \\
(5)\end{array}$ & $\begin{array}{c}\text { As } \\
(10)\end{array}$ & $\begin{array}{c}\mathrm{Au} \\
(0.05)\end{array}$ & $\begin{array}{l}\mathrm{Cu} \\
(5)\end{array}$ & $\begin{array}{c}\mathrm{Hg} \\
(0.02)\end{array}$ & $\begin{array}{l}\mathrm{Pb} \\
\text { (5) }\end{array}$ & $\begin{array}{c}\mathrm{Sb} \\
(0.5)\end{array}$ & $\begin{array}{l}\mathrm{Zn} \\
(5)\end{array}$ \\
\hline F216 & $\mathbf{N}$ & 10 & 120 & $\mathbf{N}$ & 5 & 0.12 & 35 & $\mathbf{N}$ & 20 \\
\hline F217 & $\mathbf{N}$ & $\mathbf{N}$ & 100 & $\mathbf{N}$ & L & .4 & 25 & $\mathbf{N}$ & 5 \\
\hline F220 & L & $\mathbf{N}$ & 10 & $\mathbf{N}$ & 5 & $\mathbf{N}$ & 20 & .5 & 20 \\
\hline F221 & L & $\mathbf{N}$ & 1,000 & $\mathbf{N}$ & 5 & .02 & 5 & 1 & 10 \\
\hline F223 & 200 & 200 & 12,000 & .7 & 130 & 2.0 & 4,500 & 15 & 2,500 \\
\hline F226 & L & 10 & L & $\mathbf{N}$ & $\mathbf{N}$ & .04 & 10 & 8 & 5 \\
\hline F263 & .5 & 700 & 140 & .05 & 5 & .08 & 10 & 3 & 5 \\
\hline F264 & $\mathbf{N}$ & 20 & 20 & $\mathrm{~N}$ & 10 & .34 & 10 & .5 & 15 \\
\hline F268 & L & 50 & 140 & .05 & 5 & $\mathrm{~L}$ & 20 & 4 & 60 \\
\hline F269 & $\mathbf{N}$ & $\mathbf{N}$ & $\mathbf{N}$ & $\mathbf{N}$ & 5 & .26 & 15 & 2 & 90 \\
\hline
\end{tabular}

Other veins in the southeast part of the western contiguous area are radial to the stock that forms Stony Mountain and Mount Sneffels just east of the contiguous area (Burbank and Luedke, 1966), and the veins appear related to this more local source. These relatively short veins extend only about 1 mile $(1.6 \mathrm{~km})$ from the core intrusive. Many of these veins are mineralized, and anomalous metal concentrations were detected on several. No ore-grade material was seen at the surface, but local ore bodies could exist at depth. These local veins, together with the major northwest-trending radial veins, indicate that the southeastern fringe of the western contiguous area is extensively mineralized and may have significant potential for vein-type base- and precious-metal resources at depth. 
Several veins cut the high ridge of volcanic rocks between Whipple Mountain and Hayden Peak, in the western part of the western contiguous area (pl. 1B). Dikes of intermediate composition are abundant near the veins, and larger intrusive masses are located just south and east of the mineralized area. The veins consist largely of calcite, pyrite, and altered rock at the present levels of exposure. Samples (F263, F264, F268, and F269, table 4) contained anomalous concentrations of metals similar to those in the veins near Greenback Mountain just discussed. Although no ore-grade material was seen, the character and intensity of alteration and mineralization suggest that more careful study might outline deeper exploration targets. However, the veins are not large, and it seems unlikely that major metallic resources exist.

\section{CENTRAL CONTIGUOUS AREA GEOLOGY}

The central contiguous area also consists of a high ridge of volcanic rocks set on a platform of low-dipping Paleozoic and Mesozoic sedimentary rocks (pl. $1 A$ ). Numerous granodioritic intrusive bodies were injected into the sedimentary rocks in latest Cretaceous time, and many of these were exposed by early Tertiary erosion before the Telluride Conglomerate was deposited in local channels in early Eocene time. Most of the volcanic rocks and related intrusives were emplaced in Oligocene time.

The unconformity beneath the Telluride Conglomerate and volcanic rocks is largely the stripped top of the Dakota Sandstone, with irregular patches of overlying soft Mancos Shale and local paleohills marking the tops of Upper Cretaceous intrusive bodies. Mancos Shale is especially abundant along the north margin of the central contiguous area, where the weak shales have made the overlying volcanic rocks particularly susceptible to landsliding.

Upper Cretaceous intrusive bodies are exposed near the southwest and northeast corners of the central contiguous area. A major sill was injected northward from the intrusive center at The Blowout, about 1 mile (1.6 $\mathrm{km}$ ) north of Ouray (Luedke and Burbank, 1962). This sill is largely in the lower part of the Mancos Shale, just above the contact with the Dakota Sandstone; it extends into the Dexter Creek drainage where it wedges out northward under the southwest part of the central contiguous area. Numerous crosscutting igneous and clastic dikes fill fractures in the adjacent sedimentary rocks, and some also cut the sill. Another igneous center is exposed on both sides of Cow Creek near the northeast corner of this study area. Most of the exposed intrusive rock is part of a crosscutting stock that marks the intrusive center, but part forms a semiconcordant sheet injected southward along the contact between the Mancos Shale and Dakota Sandstone. Thin dikes and sills cut the sedimentary rocks in nearby parts of Cow Creek canyon; most of these are too small to be shown 
on plate $1 A$. The Blowout center, lower Cow Creek center, and Spruce Ridge center (Dickinson and others, 1968) are arranged in a northnortheast-trending line 10 miles $(16 \mathrm{~km})$ long; the area between The Blowout and Cow Creek is almost completely covered by younger volcanic rocks. Other concealed intrusive centers could well exist along this trend.

Most of the volcanic rocks in the central contiguous area are outflow volcaniclastic sediments of the San Juan Formation. These rocks have weathered to smooth steep slopes over much of the central contiguous area, and to sheer rubbly cliffs adjacent to Cow Creek. Most of the San Juan Formation has been weakly to moderately propylitized, and it is much more compact and uniform than the fragmental rock that was originally deposited. The top of the high ridge along the southeast side of the central contiguous area is capped by Ute Ridge Tuff, the oldest widespread welded ash-flow sheet in the western San Juan Mountains.

Numerous intermediate-composition dikes radial to an intrusive center in upper Cow Creek (Luedke, 1972) extend northwestward into the central contiguous area (pl. $1 A$ ). These dikes cut both the San Juan Formation and Ute Ridge Tuff and were emplaced relatively late in the local sequence of igneous events.

\section{STREAM-SEDIMENT SAMPLES}

Stream sediments were sampled along all the main streams draining the central contiguous area (pl. $2 A$ ). Of these, only the samples from Dexter Creek and its tributaries, which drain an area of known mines, mine dumps, and mineralized veins, showed consistently anomalous concentrations of lead, zinc, silver, molybdenum, and copper. Examples are samples $\mathrm{Fl}, \mathrm{F} 5$, and Fl4 (pl. $2 A$ ). In addition, one sample from Bear Gulch contained 0.5 ppm silver; the significance of this lone anomalous value is not known.

\section{VEIN AND REPLACEMENT DEPOSITS}

Productive mines near the central contiguous area were all developed on veins and replacement bodies related to the Upper Cretaceous intrusive bodies associated with The Blowout center north of Ouray; total production has been about $\$ 13$ million in gold, silver, copper, lead, and zinc. As described by Burbank (1940, p. 200-201):

Deposits that are definitely correlated with this. [Late Cretaceous] period of mineralization extend from the vicinity of Ouray northward to Cutler Creek, a distance of 4 or 5 miles, and eastward from the Uncompahgre Valley for at least 2 or 3 miles. A fringe of deposits extends along the west side of the valley, but the intensity of mineralization decreases more abruptly westward than eastward. The deposits that extend for about 2 miles southward from the intrusive axis on both sides of the Uncompahgre Valley have not been so productive as those of the northern area. The central productive area represented by several large groups of deposits, such as those of the American Nettie and Bachelor mines, covers about 4 or 5 square miles northwest of the intrusive axis and east of the Uncompahgre Valley. 
On the basis of their metal content the ores may be divided into four groups: (1) magnetitepyrite ores containing a little copper and gold; (2) pyritic ores containing copper and gold; (3) pyritic base-metal ores containing native gold, with gold and silver tellurides; (4) siliceous and baritic ores containing silver, lead, and zinc, but commonly little gold. The gross productivity of the different groups increases in about the order named, but perhaps group 3, because of its relatively rich deposits, has returned the most on small investments. Individual mines producing from the richer silver veins of group 4 have had the highest gross productivity.

These ore deposits are zonally arranged with group 1 the central and group 4 the outer zones; they extend into the Dexter Creek area where some of the most productive mines exploiting the outer mineral zone (Burbank, 1940, p. 201) have been developed. The edge of the overlying middle Tertiary volcanic rocks extends across the zonal pattern described by Burbank, and the outer zone containing his group 4 deposits projects beneath volcanic cover in the central contiguous area northeast of Dexter Creek. Some of the known veins extend beneath the volcanics, and others undoubtedly exist in adjacent areas to the northeast.

The Upper Cretaceous intrusive mass along lower Cow Creek near the northeast corner of the central contiguous area (fig. 2; pl. 1A) showed little evidence of hydrothermal activity, and only a few small veins were seen in the poorly exposed adjacent sedimentary rocks. A few samples (F84, F85, F102, pl. $2 A$ ) of the Morrison Formation along Cow Creek contained 20-60 ppm arsenic, and other samples (F84, F93, F102, F273, pl. 2A) contained 3-6 ppm antimony. The significance of these values is uncertain; they may mark original concentrations in the Morrison shales, or they may reflect halo concentrations around the exposed lower Cow Creek intrusive center or some similar center now buried by the younger volcanic rocks. Samples of the small veins did not contain significant concentrations of valuable metals.

Other Upper Cretaceous intrusive centers may exist beneath the volcanic cover between The Blowout center and the lower Cow Creek center. Favorable host rocks for mineralization underlie the volcanics along this trend (Fischer and others, 1968, fig. 2), and these might contain vein, replacement, or porphyry-type ore bodies, similar to those peripheral to The Blowout center. Surface exposures give no indication of any such buried Upper Cretaceous mineral deposits, and exploration would have to depend on geophysical or other indirect methods of study and on extensive physical exploration.

Several veins that cut the San Juan Formation along Cow Creek in the southeastern part of the central contiguous area were deposited during the middle Tertiary mineralization. These veins are within the area cut by dikes radial to the upper Cow Creek intrusive center (fig. 2), and the veins probably are also related to that center. The veins are poorly exposed and are very inaccessible, so their lateral extent is not known. Conceivably, they occupy fissures similar to those followed by the radial dikes, which extend for several miles. 
The veins at the surface contain only sparse visible base-metal sulfides, but three samples collected from one of these veins (taken at localities F98, F99, and F101, pl. 2A), contain low but anomalous concentrations of arsenic (20-80 ppm), antimony (5-10 ppm), and mercury (0.65-1 ppm) as determined by chemical analyses. The vertical extent of mineralization would be difficult and expensive to determine because of the extremely rugged and hazardous terrain. Concentrations greatly above those determined would be required to constitute significant potential mineral resources.

\section{EASTERN CONTIGUOUS AREA}

GEOLOGY

The eastern contiguous area (pl. $1 A$ ) is most readily discussed in terms of rocks that predate and postdate formation of the Uncompahgre caldera: an older assemblage consisting of andesitic to rhyodacitic lavas and breccias of the early intermediate-composition volcanoes and overlying older ash-flow tuff units that were erupted prior to collapse, and a younger assemblage of lavas, breccias, and ash-flow tuff units that filled the caldera. The Sapinero Mesa Tuff, whose eruption was accompanied by collapse of the caldera, occurs both as a thin sheet capping the older assemblage and as a thick accumulation within the caldera. The topographic wall of the caldera which separates the two assemblages extends generally westward across the southern part of the eastern contiguous area where the complex accumulations of early intermediate-composition lavas and breccias are unconformably overlapped on the south by a mixed assemblage of younger intermediate-composition lavas and breccias and more silicic ash-flow tuffs (pl. $1 A$ ).

The topographic wall of the Uncompahgre caldera flares outward from the buried ring-fracture zone that marks the structural margin of the caldera. This structural margin is everywhere covered by caldera-fill, and its position can only be conjectured from the general structure and morphology of the caldera. It should be near the base of the topographic wall of the caldera and outside any early intermediate-composition volcanics exposed by recent erosion within the subsided block. Experience elsewhere in the San Juan volcanic field (T. A. Steven and P. W. Lipman, unpub. data) indicate that generally the structural margin marks the outer edge of the domed cores of resurgent calderas. By these criteria, the northern structural margin of the Uncompahgre caldera should be just north of the exposures of early intermediate-composition lavas along Henson Creek and its tributaries (pl. $1 A$ ) and in part beneath the line of younger rhyolite intrusives that extends across the southern part of the eastern contiguous area. This same zone appears to have localized monzonitic intrusives that cut the caldera-filling lavas and ash-flow tuffs along North Fork Henson Creek and Matterhorn Creek near the southwest corner of the eastern contiguous area. These and similar 
intrusives may have fed the intermediate-composition lavas and breccias that are interlayered with the younger ash-flow tuff units at many places around the Uncompahgre caldera.

Three obvious environments for potential mineral deposits exist within the geologic framework of the eastern contiguous area: (1) the cores of hydrothermally altered and mineralized early intermediatecomposition volcanoes that are exposed in or adjacent to the eastern study area; (2) the altered and mineralized monzonitic intrusives cutting the caldera fill above the postulated structural margin of the Uncompahgre caldera, and related metalliferous veins exposed near Henson Creek along the southern margin of the study area; and (3) the young rhyolite intrusives, emplaced largely along the postulated trend of the structural margin of the Uncompahgre caldera that are anomalously radioactive and locally contain secondary concentrations of supergene uranium minerals.

These environments were examined as carefully as time permitted. In addition, routine stream-sediment samples were collected throughout the eastern study area to detect any other less obvious concentrations of valuable minerals that might exist.

\section{STREAM-SEDIMENT SAMPLES}

Stream sediments were sampled along all the drainage systems of the eastern contiguous area (pl. 2A), and all the samples were analyzed spectrographically and chemically for selected elements. Anomalous metal contents were found only in drainage basins that contain known mineralized areas. The results of the stream-sediment sampling program are summarized, according to drainage basin, in the following paragraphs.

\section{MATTERHORN CREEK}

Matterhorn Creek is tributary to North Fork Henson Creek, largely within the original Uncompahgre Primitive Area and just west of the eastern contiguous area. It drains two overlapping areas of hydrothermally altered rocks, and several patterns of metal anomalies can be discerned in the stream-sediment analyses.

Matterhorn Creek heads in patchily altered rocks that fringe both the altered and mineralized Matterhorn volcanic center, in the headwaters of the East Fork Cimarron River, and an altered area at the Iron Beds to the southeast. The influence of the Matterhorn center is clearly shown by the distinctly higher molybdenum and lead values in samples S48-S52 (table 5) collected near the head of the drainage basin. Metal values diminish below this area and remain generally low to near the mouth of Matterhorn Creek where zinc increases sharply in samples S60-S65 collected from the main stream and from an eastern tributary draining the southeastern part of the altered area at the Iron Beds. The behavior of copper is 
particularly instructive: spectrographic analyses which measure total copper show little variation throughout the drainage basin; chemical analyses, measuring the copper extracted in cold HCL solutions $(\mathrm{CxCu}$ test) and probably largely the copper held loosely by adsorption on clay fractions, show a sharp increase in samples from lower Matterhorn Creek in direct confirmation of the spectrographic zinc anomaly. Total heavy metal content extracted in cold citrate solutions (CxHM test)-largely zinc and copper-expectably parallels the zinc-copper anomaly just described.

Both the molybdenum-lead anomaly near the head of Matterhorn Creek and the copper-zinc anomaly near the mouth are sufficiently distinctive to indicate areas worthy of further exploration. The specific source areas of the anomalous stream sediments are just outside the eastern contiguous area, but adjacent fringe areas within the contiguous area might be of economic interest as well.

\section{YELLOWSTONE GULCH}

Yellowstone Gulch is a short tributary to lower North Fork Henson Creek, just southwest of the eastern contiguous area. Several veins in the Capitol City mining area were developed within this drainage basin, and some of the mine dumps extend to the bottom of the gulch. As expected, the stream sediments are strongly anomalous. Silver ranges from below detection levels $(0.5 \mathrm{ppm})$ to $20 \mathrm{ppm}$, copper from 20 to $1,500 \mathrm{ppm}$, molybdenum from less than 5 to $30 \mathrm{ppm}$, lead from less than 10 to 2,000 ppm, and zinc from less than 200 to $2,000 \mathrm{ppm}$. No gold was detected.

\section{EL PASO CREEK}

El Paso Creek is tributary to Henson Creek, and its drainage basin includes the eastern part of the altered area at the Iron Beds, several young rhyolite intrusive bodies, and an area containing metalliferous veins near its mouth. All three of these geologic environments are reflected in analyses of the stream-sediment samples.

Samples J51-J57 and J59 (table 5) were collected near the head of El Paso Creek (pl. $2 A$ ) in an area of patchily altered rocks on the east side of the al tered area at the Iron Beds. Chemical analyses (table 5) show CxCu to be generally above background and CxHM to be spottily above background. Spectrographic analyses, measuring total metal contents, are less discriminating, and, although the copper and lead may average slightly higher in these samples than in the nonanomalous samples collected from middle El Paso Creek, the distinction is not clear.

The influence of the young rhyolite intrusives is shown largely by spectrographic analyses. Beryllium constitutes 7-15 ppm and niobium 20-50 ppm of most of the rhyolite, and these elements, especially beryllium, were widely detected in sediment samples taken near and below such intrusive bodies. Beryllium was not detected in the head- 
waters of El Paso Creek above the level of the rhyolite intrusives, but 19 samples from between the intrusion and the mouth of El Paso Creek analyzed $1-1.5 \mathrm{ppm}$ beryllium. Niobium was detected $(20 \mathrm{ppm})$ in sample $\mathrm{J} 60$ taken adjacent to one of the largest rhyolite intrusive bodies in the drainage basin.

Lower El Paso Creek, from the boundary of the eastern contiguous area to Henson Creek, contains anomalous metal contents as indicated by both the $\mathrm{CxCu}$ and $\mathrm{CxHM}$ chemical tests (table 5). This part of the drainage basin, adjacent to Yellowstone Gulch in the Capitol City mining area, is cut by related mineralized veins. Some of the anomalous metal might be derived from the eastern fringe of the altered area at the Iron Beds drained by upper El Paso Creek, but the relatively low metal values obtained from samples taken along the middle course of the stream suggest a more local origin.

\section{SOUTHERN AND SOUTHEASTERN STREAMS}

Samples from streams draining the southern and southeastern parts of the eastern contiguous area east of El Paso Creek contained little or no anomalous metal other than beryllium derived from the young rhyolite intrusives. The drainages sampled are Pole, Nellie, Modoc, Ute, and Crystal Creeks, Neoga Mountain area, the landslide area below Crystal Lake, Larson Creek, and Independence Gulch. A few random samples contained one constituent or another in slightly anomalous concentrations, but these were too few and too widely scattered to indicate local areas of potential economic interest. Beryllium in concentrations of 1-1.5 ppm was widely detected, however, and in some streams, such as Nellie Creek, it was present in almost every sample taken. Niobium is generally less than the limit of measurement by spectrographic methods $(10 \mathrm{ppm})$, although in places its presence was detected but not measured. The close association of detectable beryllium in stream sediments with the rhyolite intrusive bodies is especially well shown along Larson Creek. In 16 samples taken above a prominent rhyolite plug, beryllium either was not detected or if detected was present in concentrations too small to be measured. Of the 17 samples taken from the rhyolite plug to the mouth of Larson Creek, beryllium was detected in all but 1 and constituted $1-2 \mathrm{ppm}$ in 7 samples.

The lack of base-metal anomalies in stream sediments from the southern part of the eastern study area is significant. Scattered veins are exposed along Henson Creek, just south of the eastern contiguous area, from the Capitol City district to Lake City (pl. 1A). Most of these veins are short, but one group, developed by the Ute-Ulay mine (fig. 22), extends more than 1 mile $(1.6 \mathrm{~km})$ in strike length and may project into the southern part of the study area. Similar veins in the Capitol City area are reflected by distinct metal anomalies in stream-sediment samples, such as those taken from Yellowstone Gulch and lower El Paso Creek. The lack of 
similar anomalies to the east suggests that most of the veins are limited to the lower slopes above Henson Creek, and probably few extend into the eastern contiguous area which covers the headwaters and middle courses of the streams sampled.

The lower course of Larson Creek is about one-fourth mile $(0.4 \mathrm{~km})$ south of and parallel to the southern margin of an irregular intermediatecomposition intrusive body that marks the core of the Larson volcanic center ( $\mathrm{pl}$. 1 $A$ ). Numerous satellite dikes from this intrusive body extend southward at least to the creek, and one old prespecting tunnel half a mile $(0.8 \mathrm{~km})$ from the mouth of Larson Creek was driven northwest from creek level along an altered fracture zone. Spectrographic analyses of samples from this locality did not disclose anomalous metal contents, but samples G303-G305, taken near the mouth of the creek, contained $\mathrm{CxCu}$ and $\mathrm{CxHM}$ values slightly above background. Most of the intrusive body and all the weakly anomalous sample localities are outside the eastern contiguous area.

\section{NORTHEASTERN AND NORTHERN STREAMS}

Stream-sediment samples collected from the northeastern and northern drainage of the eastern contiguous area contain no anomalous metal concentrations. Drainage basins discussed here are Bill Hare and High Bridge Gulches, Elk Creek, Soldier Creek, Big Blue Creek, Fall Creek, Firebox Creek, and the Little Cimarron River. All these streams drain the north flanks of the clustered early intermediate-composition volcanic centers of the western San Juan Mountains, and no major intrusives are located within their drainage systems. A few dikes and minor plugs on the east side of the Cimarron volcanic center extend into the headwaters of Big Blue Creek, and radial dikes extending northward from the Larson center cross Bill Hare and High Bridge Gulches, but, apparently, there is no significant related mineralization. Outflow welded ash-flow tuff sheets cap some of the high ridges, but these are far from their sources and no known mineral concentrations accompanied their emplacement.

If Independence Gulch, with its very minor anomalous beryllium concentrations, is included, the drainage basins discussed here embrace nearly three-fourths of the eastern study area. Neither geologic mapping nor chemical analyses of stream sediments indicated mineral concentrations of potential economic interest anywhere within this part of the study area.

\section{EAST FORK CIMARRON RIVER}

The East Fork Cimarron River cuts through altered and mineralized intrusive cores of two intermediate-composition volcanoes and extends across the volcaniclastic apron on the north side of the volcanic complex. Stream-sediment samples clearly show the influence of the altered areas, particularly in the widespread anomalously high copper content, and less prominently in the zinc content.

Stream-sediment samples S4-S11 (table 5), collected between about 
three-fourths mile $(1 \mathrm{~km})$ below the highly altered Matterhorn center and the Cimarron center (pl. 2A), have copper contents of 15-30 ppm by spectrographic methods and 2-10 ppm (average $4.4 \mathrm{ppm}$ ) by $\mathrm{CxCu}$ methods. Sporadic anomalous zinc concentrations are indicated by spectrographic analyses but not clearly by the CxHM analyses.

Samples S12-S18 from within or adjacent to the Cimarron center ranged from 8 to $15 \mathrm{ppm}$ (average $8.7 \mathrm{ppm}$ ) copper by the CxCu method and from 15 to $20 \mathrm{ppm}$ by the less discriminating spectrographic method. The nearly twofold increase in average copper determined by the $\mathrm{CxCu}$ method is interpreted to reflect contributions from the altered and mineralized rocks of the Cimarron center.

Downstream from the Cimarron center the copper content of stream sediments drops off somewhat to the range of less than 1 to $10 \mathrm{ppm}$ (average about $5.4 \mathrm{ppm}$ ) copper by the CxCu method. Total copper in the samples as indicated by spectrographic analyses averages about $20 \mathrm{ppm}$, about the same as samples higher in the drainage basin. Sporadic anomalous zinc values were detected throughout the drainage area by both spectrographic and $\mathrm{CxHM}$ analyses.

Compared with the background of samples from streams draining similar rocks to the east, the samples from the East Fork Cimarron River drainage are slightly but distinctly anomalous in copper and zinc. The higher copper content in samples near the altered Cimarron center pinpoints one probable source, and the even more altered and mineralized Matterhorn center at the head of the drainage is another obvious source. Both areas will be considered individually later in this report.

\section{MIDDLE FORK CIMARRON RIVER}

A short segment of the Middle Fork Cimarron River borders the eastern contiguous area. Samples taken along this segment showed no clear-cut metal anomalies by spectrographic methods, although the copper (15-20 ppm) may average somewhat higher than the background established by samples from streams farther east (generally 5-15 ppm). However, chemical analyses by the $\mathrm{CxCu}$ method show 2-7 ppm loosely held copper, definitely above background, which is generally l ppm or less.

These values show no significant variation within the area sampled and are generally comparable to values obtained well below the altered volcanic centers on the East Fork Cimarron River. The western end of the Cimarron volcanic center extends into Porphyry Basin, tributary to the Middle Fork several.miles upstream from the sampled area, and might well be the source of the anomalous copper values.

\section{MINERALIZATION ASSOCIATED WITH EARLY INTERMEDIATE VOLCANIC CENTERS}

During early intermediate-composition volcanic activity, 35-30 m.y. ago, a clustered group of volcanoes formed in the western San Juan 
Mountains area. Many of these volcanic centers have since collapsed into the Uncompahgre and San Juan calderas and have been covered by younger deposits, but a few centers outside the collapsed area are now marked by near-source lavas and breccias surrounding intrusive cores. Two of these centers are just outside the north wall of the Uncompahgre caldera (figs. 1, 2): the Larson center between the east margin of the eastern contiguous area and the Lake Fork Gunnison River and the Cimarron center, largely on the ridge between the East and Middle Forks Cimarron River. All these centers have been altered and mineralized.

A similar early intermediate intrusion south of the Uncompahgre caldera at the old mining camp of Carson is hydrothermally altered, and the surrounding lavas and breccias are cut by numerous small metalliferous veins. An estimated $\$ 200,000$ worth of metals have been produced from the Carson Camp (Vanderwilt, 1947, p. 115).

\section{LARSON CENTER}

The Larson center is marked by an irregular intrusive plug exposed on the ridge between lower Larson Creek and Independence Gulch (pl. $1 A$ ). Numerous dikes radiate from this center; some extend as far as 3 miles ( 5 $\mathrm{km})$ north into Bill Hare and High Bridge Gulches. The intrusive center is irregularly altered, and a few small prospect pits have been dug.

Little mineralized material except for some irregularly hydrothermally altered rock was seen. Samples of the dump of an adit along Larson Creek taken by the U.S. Bureau of Mines were not encouraging. Streamsediment samples taken along Larson Creek adjacent to the intrusive center contained slightly anomalous metals by $\mathrm{CxCu}$ and $\mathrm{CxHM}$ analyses, but samples from Independence Gulch to the north were virtually at background levels.

Most of the intrusive center and all the anomalous samples are outside the eastern contiguous area. This distribution and the weak evidence for mineralization indicate that the eastern contiguous area near the Larson center has little economic potential

\section{CIMARRON CENTER}

An elongate monzonite intrusion extends from near the Silver Jack mine, on the East Fork Cimarron River, west across a high ridge into Porphyry Basin, tributary to the Middle Fork Cimarron River (pl. $1 A$ ). Numerous dikes cut the surrounding lavas and breccias. This intrusive center appears to mark the core of a relatively young volcano within the early intermediate-composition assemblage of volcanics, although the field relations do not preclude a possibility that the intrusions are younger than the early intermediate near-source accumulation. The lower slopes of the ridge are mostly outflow-facies mudflow breccias from older sources to the south, but the upper parts of the ridge consist largely of near-source lavas and breccias that formed the volcanic edifice around 
the Cimarron center. The main intrusion cuts both the mudflow breccias and the overlying near-source lavas. Most rocks near the Cimarron Volcano were propylitically altered, and disseminated pyrite is widespread. This pervasive alteration probably resulted from reactions with hot carbonate-bearing water that permeated the volcano and underlying rocks late in its development.

Subsequent to the propylitic alteration, the main intrusion was in part hydrothermally altered to red and yellow argillized and silicified rocks with abundant disseminated pyrite. Similarly altered fractures that cut the surrounding volcanics are followed by some of the associated dikes. Many of these fractures were extensively prospected, particularly in Porphyry Basin and near the Silver Jack mine. Mudflow breccias near the Silver Jack mine are cut by numerous dikes and altered fractures, which contain local concentrations of sulfides, largely pyrite. Most prospect pits and short adits were dug along altered dikes that localized the late mineralized shears and veins.

Some analyzed samples (table 6) are representative of the altered rock in general, but others were taken from the apparent highest grade parts of the exposed veins. Many of these latter samples contained slightly anomalous silver, arsenic, copper, molybdenum, lead, antimony, tellurium, or zinc by either or both spectrographic or chemical analyses, but only one $(\mathrm{S} 86 \mathrm{H})$ was strongly anomalous in more than one metal. Even this sample did not approach ore grade: The most anomalous samples commonly contained limonite and may reflect some secondary concentration of metals. These largely negative results indicate a low potential for vein deposits.

Veins also occur in Porphyry Basin near the western end of the intrusive mass. These deposits are outside the eastern contiguous area and were not examined by the U.S. Geological Survey. U.S. Bureau of Mines personnel sampled the area, however, and their results indicate anomalous concentrations of copper, lead, and molybdenum, but no ore-grade material.

Two sample traverses were made across the irregularly altered central intrusion of the Cimarron Volcano. Ten samples of the intrusion and altered wallrocks were taken along the lower slopes just west of the East Fork Cimarron River (S85A-J, table 6), and seven additional samples were collected along the ridgecrest between the East and Middle Forks (S170-S175, table 6). A few samples contained slightly anomalous quantities of silver, arsenic, copper, molybdenum, lead, antimony, tellurium, or zinc, but anomalies are so scattered and so slightly above background that only a low economic potential is indicated for the central intrusion.

\section{MINERALIZATION ASSOCIATED WITH INTRACALDERA INTRUSIONS}

Monzonitic intrusions cut the Uncompahgre caldera fill at several places within, south, and southwest of the eastern contiguous area (pl. 1). 
These bodies probably were emplaced late in the Uncompahgre caldera cycle, and in part they may represent feeders for the intermediatecomposition lavas and breccias that are interlayered with the younger ashflow units and fill the northern caldera moat. The intrusions are commonly altered and locally have metalliferous veins associated with them.

\section{MATTERHORN CENTER}

An elongate monzonite intrusion, about 5,000 feet $(1,500 \mathrm{~m})$ long and 1,000 feet $(300 \mathrm{~m})$ wide, cuts early intermediate-composition lavas and breccias on the north slope of Matterhorn Peak in the headwaters of the East Fork Cimarron River (pl. $1 A$ ). The intrusion and adjacent wallrocks are widely altered. Prospect pits and trenches have been dug, and bulldozer roads cut.

The Matterhorn center probably is the core of an intracaldera-age volcano. The halo of intensely argillized and pyritized rock along the south side of the intrusive appears to extend up into propylitically altered Ute Ridge Tuff, although the argillization and pyritization of the older rocks in places greatly exceeds that in the younger Ute Ridge Tuff. On the south side of Matterhorn Peak, the altered area centered on the Iron Beds area to the southeast overlaps the altered area related to the Matterhorn center.

This intrusive center is just west of the eastern contiguous area, but stream sediments containing anomalous concentrations of metals derived from this area were collected along both Matterhorn Creek and the East Fork Cimarron River (table 5), and the eastern fringe of the alteration halo around the center closely approaches the western boundary of the study area. In consequence, the intrusive center was examined briefly and 21 samples of altered and mineralized rock were analyzed (table 6 ). In the 21 samples silver, arsenic, copper, molybdenum, lead, zinc, and tellurium were widely but irregularly detected in anomalous concentrations. Particularly significant are widespread anomalous copper, molybdenum, lead, and arsenic, which indicate pervasive mineralization centered on the altered intrusive plug. Stream-sediment samples from the head of Matterhorn Creek, which is within the alteration halo around the Matterhorn center, also contain anomalous molybdenum and lead. Scattered altered rock samples from the upper Matterhorn Creek area, not tabulated, are anomalous in the same elements as those from the intrusive center to the north.

All rock samples taken in and near the Matterhorn intrusive center were from surface exposures where leaching by acidic meteoric water probably has reduced the metal content and obscured the anomalies. This probability receives some support from unverified reports of visible molybdenite in the shallow workings along the East Fork Cimarron River. The presence of molybdenum at the Matterhorn center has also 
been indicated by Clark $(1972$, figs. 3,4$)$ but the source of his information was not given.

The widespread anomalous metal values and the pervasive alteration and pyritization centered on the core intrusive indicate a possible exploration target. Veins are obscure around the center, and the potential seems much better for a disseminated "porphyry-type" deposit containing copper or molybdenum, or both. The shallow volcanic environment now exposed is above the deeper volcanic or subvolcanic environment in which most porphyry-type deposits are found, and extensive deep drilling probably would be required to test the mineral potential adequately.

\section{CAPITOL CITY MINING AREA}

The Capitol City mining area, 1-2 miles (1.6-3.2 km) southwest of the eastern contiguous area near the confluence of Henson Creek and its North Fork, is centered on several monzonitic intrusions. The intrusions and adjacent country rock are widely but irregularly altered and are cut by numerous small metalliferous veins that produced significant precious metals in early mining (Irving and Bancroft, 1911). Veins of the Capitol City mining area occur on both slopes adjacent to lower North Fork Henson Creek (pl. 1 $A$ ). All the veins are just outside both the original Uncompahgre Primitive Area and the eastern contiguous area. However, the ore deposits are typical of what might be expected at depth beneath the altered area at the Iron Beds to the north, so some stream-sediment and altered-rock samples were taken for comparison purposes.

The mineral deposits and mines in the Capitol City area have been described in detail by Irving and Bancroft (1911, table 2, p. 72-81). The veins consist largely of quartz, galena, and sphalerite, with lesser pyrite, chalcopyrite, and tetrahedrite. Minor gangue minerals are barite, sericite, and rare fluorite. The veins are generally less than 1,000 feet $(300 \mathrm{~m})$ long, and most are only $1-2$ feet $(0.3-0.6 \mathrm{~m})$ wide. Ore shoots within the veins are generally much more restricted and in places form only a small part of the associated vein. The fissures filled by the veins show little evidence of significant displacement and appear largely to be discontinuous fractures.

The exploited veins are largely around the northern periphery of a highly altered area containing numerous small monzonitic intrusions. This altered area extends south from North Fork Henson Creek, across the east flank of Sunshine Mountain, Henson Creek, and up the south wall of Henson Creek canyon to be cut off abruptly by the bounding fault of the younger Lake City caldera. Stream-sediment samples from Yellowstone Gulch, within the area of developed mines, are highly anomalous. Ten samples of altered rock from the south side of North Fork Henson Creek (not tabulated) contain highly anomalous concentrations of silver, copper, molybdenum, lead, zinc, antimony, and arsenic, as well as local 
gold, as expected within an area of developed mines. Nine additional samples of altered rock from the lower slopes south of Henson Creek (not tabulated) show distinctly anomalous silver and molybdenum and somewhat anomalous arsenic and antimony.

This reconnaissance sampling suggests that the whole eastern flank of Sunshine Mountain might warrant study to determine whether disseminated mineralization might be associated with the Capitol City intrusive center. This area extends south under a broad flat valley of Henson Creek where it is covered by alluvium and glacial drift; geophysical methods and drilling would be required to test the mineral potential here. The samples taken along the south side of the valley were not nearly as anomalous as those to the north, but they are still sufficiently so to encourage study.

\section{ALTERED AREA AT THE IRON BEDS}

The altered area at the Iron Beds is high on the slopes east of Matterhorn Creek and extends into the El Paso Creek drainage to the east and the East Fork Cimarron River drainage to the north. Most of the altered area is in the original Uncompahgre Primitive Area and is just west of the eastern contiguous area (pl. $1 A$ ). A wide variety of rocks are altered, including intermediate-composition lavas in the Henson and Burns Formations and the volcanics of Uncompahgre Peak and ash-flow tuffs in the Fish Canyon, Crystal Lake, and Carpenter Ridge Tuffs. In detail, the alteration was controlled in part by lithology, but the altered area seems localized near a cluster of small monzonitic intrusive bodies. Some of these are shown on plate $1 A$ in the headwaters of Matterhorn Creek, but others were too small to be shown or were too altered to be mapped in the time available. The rocks are irregularly argillized, silicified, bleached, and oxidized. Pyrite is abundantly disseminated throughout the area. Much of the pyrite has been removed from the near-surface rocks, and supergene leaching of metals probably has occurred.

Stream-sediment samples from lower Matterhorn Creek and upper El Paso Creek contain anomalous metal concentrations that seemingly were derived from the altered area at the Iron Beds. Twenty-three bedrock samples (G328A-G3285, S164A, S167-S169), largely from altered rocks in the central part of the altered area, also indicate local anomalous metal concentrations (table 6). Silver was detected and was, therefore, anomalous in two of the samples; copper and lead were erratically anomalous by both spectrographic and chemical analyses, as were zinc, arsenic, antimony, and tellurium by chemical analyses; and six of the samples contained anomalous molybdenum.

These results, in conjunction with stream-sediment-sample analyses, indicate that the altered area at the Iron Beds contains widespread slightly anomalous metal concentrations. The sample coverage was too uneven to establish distribution patterns for the different metals or to pinpoint local exploration targets. 
Scattered veins are exposed along the lower slopes on both sides of Henson Creek from the Capitol City area 8 miles $(13 \mathrm{~km})$ east to Lake City (pl. 1A). The largest groups of veins are near the mouth of El Paso Creek, just east of Ute Creek, and on the lower south slope of Neoga Mountain. The veins are very similar to those in the Capitol City area except for the local occurrence of rhodochrosite as a major gangue mineral (Irving and Bancroft, 1911, table 2, p. 81-99). Most veins are fairly short, generally less than 1,000 feet $(305 \mathrm{~m}$ ) in length, but the group developed by the Ute-Ulay and Hidden Treasure mines extends for more than 3,300 feet $(1 \mathrm{~km})$ from Henson Creek northeast to near and perhaps across the southern boundary of the eastern contiguous area. As in the Capitol City area, there is little evidence for significant displacement along these veins, and even the longer ones do not appear to offset geologic contacts or local flows appreciably. One monzonitic intrusive, Sugarloaf Rock, cuts the caldera fill on the south slope of Neoga Mountain, but none of the veins appears closely related to it.

Of the known veins, only those developed by the Ute-Ulay, Hidden Treasure, and Pelican mines extend near and perhaps into the eastern contiguous area. Only the veins near the mouth of El Paso Creek extend across a major drainage, and these were clearly reflected in the anomalous concentrations of metals in stream-sediment samples collected along lower El Paso Creek. The lack of similar anomalies in the other streams draining the southern part of the contiguous area suggests that few if any of these veins exist within their middle or upper drainages. However, brief examinations made at mines south of the eastern contiguous area suggest that worthwhile targets for exploration may well exist along some of the veins. The vein system developed by the Ute-Ulay and Hidden Treasure mines in particular appears favorable.

\section{MINERALIZATION ASSOCIATED WITH RHYOLITE INTRUSIONS}

An east-northeast-trending line of rhyolite intrusions cuts the caldera fill near the northern wall of the Uncompahgre caldera. These intrusions extend from the Mary Alice Creek tributary of North Fork Henson Creek, west of the eastern contiguous area, across the southern part of the study area to Larson Creek, near the east margin of the area (pl. 1 $A$ ). The intrusions range from oval-shaped plugs and irregular small crosscutting masses to concordant and semiconcordant sills and wedge-shaped laccolithic bodies. The sills and laccoliths were generally injected along local sedimentary units between lava flows or ash-flow sheets in the caldera fill and appear to have been fed from the crosscutting plugs. The main bodies mapped are: a stubby irregularly branching dike at Broken Hill and upper El Paso Creek, local small plugs and sills between El Paso and Pole Creeks, a major wedging sill or laccolith between the east and west forks of Nellie Creek that extends west of the west fork of Nellie 
Creek, an oval-shaped plug along the east fork of Nellie Creek, and an elongate plug in the Larson Creek drainage.

The rhyolite is a distinctive siliceous rock (76-77 percent $\mathrm{SiO}_{2}$ ) with abundant quartz and sodic sanidine and sparse biotite phenocrysts set in a white to light-gray devitrified groundmass. Hydrated vitrophyres occur locally along the margins of some crosscutting bodies. Part of the devitrified rhyolite is distinctly vesicular and locally contains a fibrous cavityfilling mineral that is possibly a zeolite. Small euhedral topaz crystals and powdery purple fluorite occur in some vesicles and along minor fractures. Megascopically the rock appears fresh and unaltered, and the wallrocks show minor evidence of baking but none of hydrothermal alteration. No veins were seen either in the intrusive bodies or in the wallrocks.

All the intrusive rhyolite is anomalously radioactive, and scintillator field measurements are commonly twice or more those of the wallrocks. Three local areas were seen where the rhyolite contains secondary yellow uranophane along fractures near the contacts with wallrocks. Since 1968, several exploration programs by industry have tested the economic potential of several of these rhyolite plugs. As a result, the rhyolite intrusive bodies were examined carefully, were sampled extensively, and were analyzed chemically by several methods (tables 7,8 ).

Sediment samples were taken along all the streams draining the area containing the rhyolite bodies as part of the general sampling program. In addition, all the main intrusive bodies were examined in more detail, radioactivity was measured, and the rock was sampled along traverses planned to obtain maximum coverage in the time available. Limited time did not permit extensive petrographic study of the rocks.

Representative samples were anlayzed spectrographically, and some were also analyzed chemically (table 7 ). The equivalent uranium (eU) content of 40 samples was checked by the beta-gamma scaler method, and the uranium and thorium contents were measured by the delayed neutron method (table 8). The uranium and thorium contents of one sample, L47, were determined by gamma-ray spectrometry as well; its values (table 8) are similar to those obtained by the delayed neutron method. These data show the distribution of many of the elements of possible economic significance and permit interpretation of their behavior during intrusion and subsequent cooling of the rhyolite.

\section{GEOCHEMICAL DATA}

High-silica alkali rhyolite magmas like those that formed the intrusions in the eastern contiguous area are enriched during magmatic differentiation in many minor constituents, including beryllium, fluorine, molybdenum, niobium, tin, thorium, uranium, and tungsten (Nockolds and Allen, 1953; Turekian and Wedepohl, 1961). Not all these elements, however, are comparably enriched in all alkali rhyolites, and each local area generally has its own characteristic assemblage and 
relative concentrations. Because many of these elements are mobile, they may be variably enriched or depleted locally in an intrusion during cooling and crystallization. The extensive analytical work during this investigation provides data bearing on these postemplacement processes.

Attention will be focused chiefly on the behavior of fluorine, uranium, thorium, beryllium, molybdenum, niobium, and tin in the rhyolite and wallrocks. Six samples of marginal vitrophyre were collected: four (S47F, S106B, S110A, and L47) were from the northern and eastern margin of the plug along the east fork of Nellie Creek, and two (G324J and G324K) were from the body on Broken Hill. These samples are assumed to represent the least modified part of the original rhyolite magma available, and the analytical results are compared with those from the devitrified parts of the intrusions and the wallrocks.

Fluorine was determined by specific-ion analyzer on most samples of rhyolite that were chemically analyzed, and, in addition, on a few samples that were tested for radioactivity only. Values ranged erratically from below the limit of detection $(50 \mathrm{ppm})$ to $1,300 \mathrm{ppm}$. The highest value was from a marginal vitrophyre (G324K), but other measurements on vitrophyres ranged from less than 50 to $700 \mathrm{ppm}$ fluorine. Similar erratic results were obtained from devitrified rhyolites, although most of these were only a few hundred parts per million fluorine or less. The scattered high values, along with local occurrence of topaz in vesicles and fluorite along fractures, probably indicate that the original magma contained significant fluorine; the erratic but generally low values in devitrified rhyolite are interpreted to indicate general expulsion of fluorine during cooling and crystallization. Loss of fluorine during crystallization of rhyolitic magmas has also been documented by Noble, Smith, and Peck (1967) and by Lipman, Christiansen, and Van Alstine (1969).

The distribution of uranium and thorium in the samples is particularly instructive. Analyzed marginal vitrophyres (S110A and L47, table 8) contain about $40 \mathrm{ppm}$ uranium, 55-63 ppm thorium, and have a thorium/uranium ratio of $1.4-1.6$; these concentrations are anong the highest measured except for samples taken near obvious sec ondary uranophane. Field scintillator determinations for all the sampled vitrophyres (tables 7,8 ) confirm this conclusion. Wallrock samples generally contain appreciably less uranium and thorium, and the field radiometric readings were distinctly lower. Sample $\mathrm{S} 108$ is not consistent with this conclusion, and analytical results do not agree with field readings. A misidentified sample is suspected.

Most devitrified rhyolite appears to be significantly depleted in uranium and considerably less depleted in thorium. The core of the plug along the east fork of Nellie Creek (table 8) contains only about half as much uranium (22-25 ppm) as the marginal vitrophyres, whereas the thorium is not appreciably different. The thorium/uranium ratios for 
devitrified rock are 2-2.6 in contrast with 1.4-1.6 for vitrophyres, also indicating relative depletion of uranium. The devitrified rock from the sill between the east and west forks of Nellie Creek and west of the west fork of Nellie Creek contains even less uranium, and the thorium is also somewhat less; the relatively greater depletion of uranium is reflected by the many thorium/uranium ratios greater than 2. Devitrified rock from the rhyolite plug along Larson Creek, in general, contains the least uranium measured (10-20 ppm), and the rock has consistently high thorium/uranium ratios, indicating relative depletion. The small intrusions in the upper El Paso Creek area, on the other hand, have more uranium (26-37 ppm) and have lower thorium/uranium ratios (1.3-2.1) than any of the rhyolite other than the marginal vitrophyres, indicating significantly less removal of uranium from these bodies.

One El Paso Creek sample (G325C, table 8), from a small prospect where secondary uranophane was locally concentrated along minor fractures in the rhyolite, expectedly contains high uranium and thorium as a result of secondary enrichment. The relatively uniform uranium and thorium concentrations in the other samples, in comparison with this obviously enriched specimen, accord with the postulated general depletion of uranium in most devitrified rocks. Depletion of uranium from crystallized volcanic rocks, in comparison with glassy parts of the same units, has also been carefully documented by Rosholt and Noble (1969).

Beryllium is generally high in all intrusive rhyolite bodies and was commonly detected in stream-sediment samples taken below outcrops of the rhyolite. Comparison of concentrations of beryllium in the six marginal vitrophyre samples (mostly $15-20 \mathrm{ppm}$, with one of $7 \mathrm{ppm}$ ) with those in the other rhyolite samples also indicated depletion in the devitrified rock. Most samples of devitrified rock from the Nellie Creek basin contained 7-15 ppm beryllium, and samples from the core of the plug along Larson Creek contained only 7 ppm beryllium. This relative depletion closely parallels the behavior of uranium, with devitrified rock in the Nellie Creek basin showing intermediate loss and in the Larson Creek basin the greatest loss. Significantly, samples from the Broken Hill body and the small intrusives in upper El Paso Creek, which showed little depletion in uranium, also contained nearly as much beryllium as the samples of marginal vitrophyre.

Molybdenum shows the same general pattern as uranium and beryllium. Molybdenum was detected in all but one of the vitrophyre samples, and it was as high as $15 \mathrm{ppm}$ in two samples (both from the plug along the east fork of Nellie Creek). It was erratically detected (generally 5-7 ppm) in some devitrified samples from the plug along the east fork of Nellie Creek, but only in a very few samples from the sill between the east and west forks of Nellie Creek, or from the Broken Hill dike. Molyb- 
denum was below detectability in samples from the sill west of the west fork of Nellie Creek and from the plug along Larson Creek. It was detected in most samples from the small intrusives in upper El Paso Creek where it commonly is present in quantities comparable with those in the marginal vitrophyres. The broad parallelism with the behavior of uranium and beryllium is apparent, with greatest depletion in the plug along Larson Creek and least depletion in the small El Paso Creek intrusive bodies.

These patterns closely parallel those discovered by Haffty and Noble (1972), who clearly showed depletion of molybdenum from peralkaline silicic volcanic rocks during crystallization. In contrast with our data, Haffty and Noble found no comparable depletion in beryllium but suggested that this fact may have been due to the peralkaline composition of their rocks.

Niobium concentrations are $20-50 \mathrm{ppm}$ in most samples of intrusive rhyolite and, locally, are as much as $80 \mathrm{ppm}$. No pattern of distribution was discerned between marginal vitrophyre and devitrified rock, or from place to place within an intrusive body. The plug along Larson Creek and the sill west of the west fork of Nellie Creek average somewhat lower than the other bodies, but the significance of this is not known. No regular pattern of depletion or enrichment comparable to those interpreted for uranium, beryllium, and molybdenum is apparent.

Tin was widely but erratically detected in all rhyolite intrusive bodies except the plug along the east fork of Nellie Creek. In most samples the concentration was not sufficient to be measured; thus, comparisons cannot be made. Tin was widely detected both in the Larson Creek plug, where uranium, beryllium, and molybdenum showed greatest depletion, and in the small intrusive bodies in El Paso Creek, which show the least depletion in these elements. Tin was detected in only one vitrophyre sample. These data suggest that tin was neither depleted nor enriched comparably with uranium, beryllium, and molybdenum during crystallization.

\section{ECONOMIC SIGNIFICANCE}

Except for local areas containing small concentrations of secondary uranophane in the rhyolite, no evidence for economic deposits was seen in or near the rhyolite intrusive masses. The relatively high concentrations of fluorine, uranium, thorium, beryllium, molybdenum, niobium, and tin in samples are typical of high-silica alkali rhyolites and result largely from normal magmatic differentiation. Careful review of the geochemical data indicates that the devitrified rhyolite comprising the bulk of those bodies is actually somewhat depleted in fluorine, uranium, beryllium, and molybdenum compared to the original magma, as best represented by local marginal vitrophyres. No concentrations of any of 
these depleted metals were detected in wallrocks adjacent to the intrusive bodies, although all exposures of these rocks near the intrusives were examined carefully and were checked extensively for radioactivity.

The timing of this depletion is critical to interpretation of the economic potential of the rhyolite intrusive masses. Seemingly, the intrusions could have been depleted during cooling and crystallization, when many minor elements and volatile constituents, such as water and the halogens, that did not fit well into lattices of the rock-forming minerals were expelled. On the other hand, the depletion might have taken place much later owing to leaching by downward-percolating ground water; this hypothesis was tentatively favored by Rosholt and Noble (1969) in their study of the loss of uranium from crystallized volcanic rocks. Under the first alternative, the depleted elements would probably have been expelled upward and out of the now-exposed environment; under the second alternative, they would have entered the ground-water regime and have been dispersed outward into the surrounding rocks where some may have been deposited locally in significant concentrations.

Several lines of reasoning favor expulsion during cooling and crystallization: (1) the pattern of distribution of many elements reflects vitric versus devitrified rock; (2) no difference was noted between dense devitrified rock and more permeable vesicular devitrified rock that might have channeled ground water; (3) each intrusive body appears to have characteristic concentration patterns; and (4) the depleted elements are a related group that are mobile during cooling and crystallization of silicic igneous rocks. Fluorine appears to be a key element: uranium, beryllium, and molybdenum are all readily mobile as halogen complexes, and, inasmuch as fluorine and probably chlorine were expelled, they may have scavenged uranium, beryllium, and molybdenum from the crystallizing magma and carried them out of the local system. No evidence was seen for nearby precipitation, and the emanations probably traveled upward toward a near-surface thermal spring or fumarolic environment associated with the local igneous centers. Conceivably, the depleted rhyolite bodies could represent sources similar to those inat supplied the nearsurface fluorite-bertrandite deposits at Spor Mountain, Utah (Staatz, 1963; Staatz and Griffitts, 1961), or the shallow fluorite deposits at Northgate, Colo. (Steven, 1960), and elsewhere in the Western United States. Such levels of possible precipitation have all been eroded from above the exposed rhyolite intrusives in the southern part of the eastern contiguous area.

The local areas containing secondary uranophane represent local oregrade concentrations that conceivably have economic potential. All the uranophane deposits seen are in rhyolite and are concentrated in fractures near contacts with wallrocks. The fractures appear to be minor shears that developed in the solidified margins of concordant bodies during intrusion. Observed fracture zones are apparently too limited in extent to localize large ore bodies. No secondary concentrations of uranium were 
detected in adjacent wallrocks, and in particular the local sedimentary units that localized most of the sills and laccoliths appear devoid of uranium concentrations. Significant concentrations of secondary uranium may exist somewhere in association with the rhyolite bodies, but these would be controlled by conditions not observed during this investigation, and, therefore, are not predictable from present data.

\section{INTERPRETATION OF AEROMAGNETIC DATA}

By Peter Popenoe and R. G. Luedke, U.S. Geological Survey

An aeromagnetic survey of a region in southwestern Colorado that includes the Uncompahgre Primitive Area and the three contiguous study areas was flown by the U.S. Geological Survey in 1969 as part of a wilderness investigation program. Traverses spaced about 1 mile $(1.6 \mathrm{~km})$ apart were flown in an east-west direction at a barometric elevation of 14,500 feet $(4,400 \mathrm{~m})$, and the total intensity magnetic field was recorded with fluxgate magnetometer. The aeromagnetic map of the primitive and contiguous areas is shown in figure 3.

The regional magnetic high associated with the San Juan Mountains volcanic field is best seen on the aeromagnetic map of Colorado by Zietz and Kirby (1972) and the aeromagnetic map of the Ridgeway-Pagosa Springs area, southwestern Colorado (U.S. Geol. Survey, 1972). Regional aspects of the aeromagnetic and gravity fields associated with the volcanic field have been discussed by Plouff and Pakiser (1972) who have interpreted the regional gravity low and magnetic high in the area as reflecting a near-surface batholith genetically related to the caldera complex and volcanic field. Model studies of the anomalies show that the top of this concealed batholith ranges from 0.5 to 1.75 miles $(0.8-2.8 \mathrm{~km})$ below the surface and is nearest the surface in the area of the Lake City caldera located south of the western contiguous area.

A preliminary interpretation of the aeromagnetic pattern of the Uncompahgre Primitive Area was released in August 1970 (Popenoe and Luedke, 1970). However, recent reinterpretations of the volcanic stratigraphy and caldera-collapse structures within and near the primitive area (Lipman and others, 1973) necessitate a reinterpretation of the local aeromagnetic pattern of the original primitive area and the three contiguous areas.

\section{MAGNETIC SUSCEPTIBILITY MEASUREMENTS}

Measurements of magnetic susceptibilities were made for 54 samples of rocks from the Uncompahgre Primitive Area and surrounding areas. These samples are listed individually with locations in Popenoe and Luedke (1970) and summarized herein on the basis of reclassification with the geologic units used in this report.

Although only a few of the rock units were measured for magnetic susceptibilities in the Uncompahgre Primitive Area and surrounding areas, the validity of the results is borne out by observation of the expression of these units on the magnetic map. The Upper Cretaceous intrusive rock 


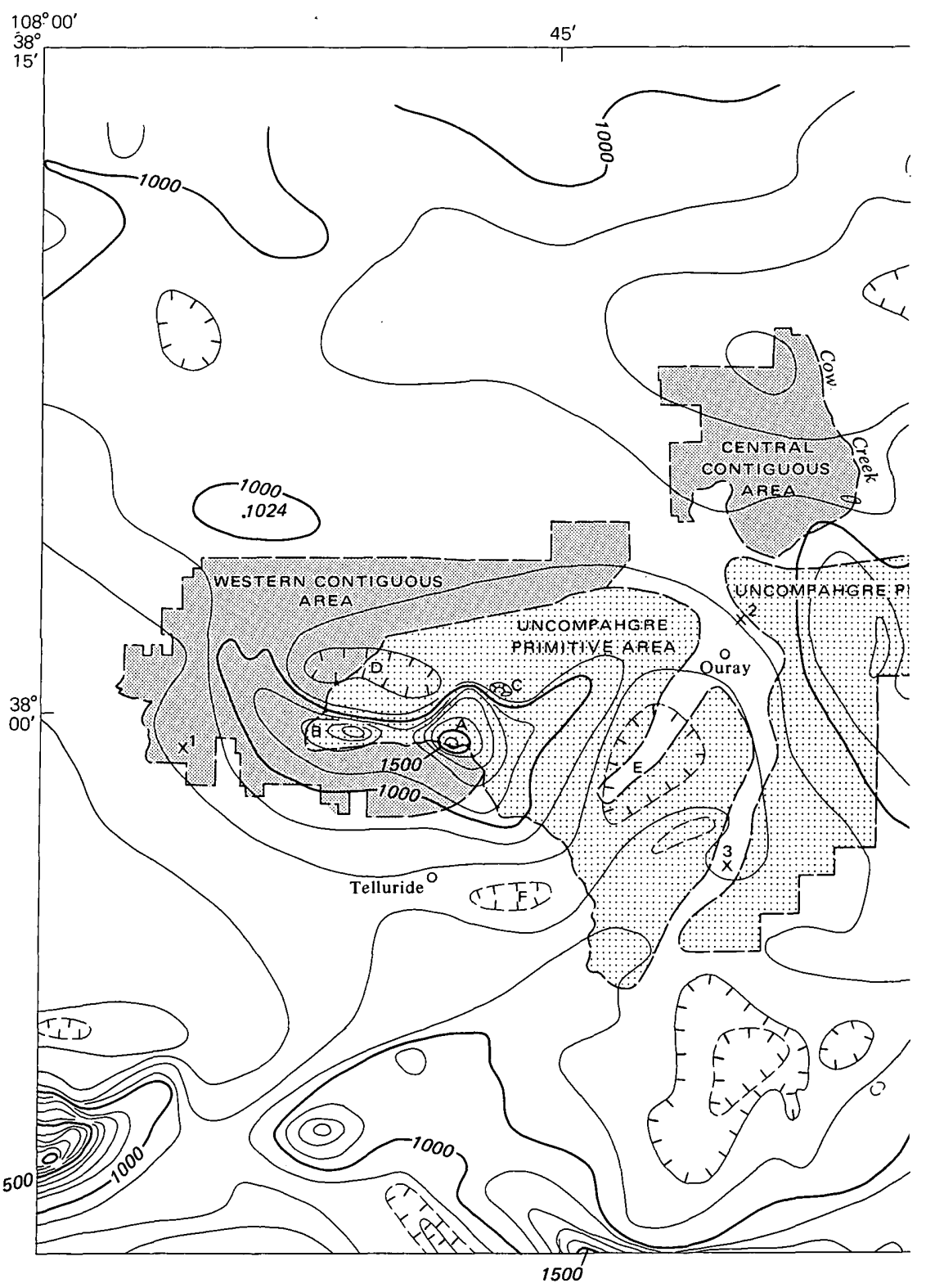

FIGURE 3.-Preliminary aeromagnetic map of the Uncompahgre Primitive Area and eastern, central, and western contiguous areas. Contours show total intensity magnetic field of the earth in gammas relative to arbitrary datum; hachures indicate 


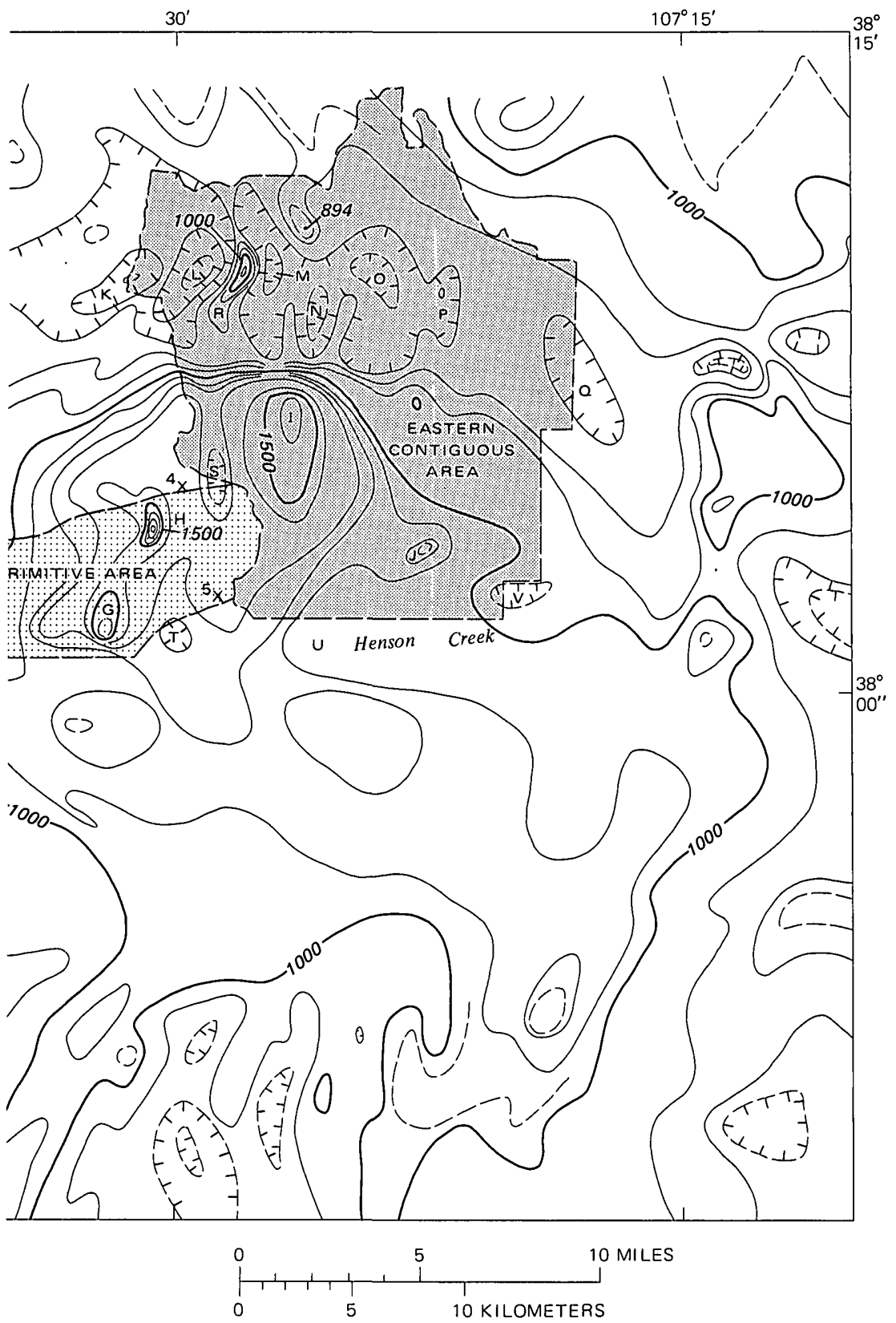

closed areas of lower magnetic intensity. Selected measured maximum or minimum intensities, in gammas, are also shown. Points of reference: 1, Whipple Mountain; 2, The Blowout; 3, Ironton; 4, Matterhorn Peak; 5, Iron Beds. A through $V$ represent anomalies discussed in text. 
from a laccolith along Cow Creek showed an intermediate susceptibility of $1.4 \times 10^{-3} \mathrm{emu} / \mathrm{cm}^{3}$ (table 9), and on the aeromagnetic map the Upper Cretaceous intrusives at Cow Creek and at The Blowout and vicinity near Ouray show no aeromagnetic expression even through they are surrounded by nonmagnetic sedimentary rocks. This finding is explained by the intermediate susceptibility of the intrusives, their low topographic position remote from the detector, and their occurrence mainly in relatively thin sills and laccoliths that form most of the intrusive bodies. The discordant stock at The Blowout is highly altered suggesting that this stock has a very low magnetic susceptibility owing to destruction of magnetite by leaching solutions.

TABLE 9.-Magnetic measurements of intrusive rocks, Uncompahgre Primitive Area and surrounding areas

\begin{tabular}{|c|c|c|c|}
\hline \multirow{2}{*}{ Rock type } & \multirow{2}{*}{$\begin{array}{c}\text { Number of } \\
\text { samples }\end{array}$} & \multicolumn{2}{|c|}{$' K \times 10^{-3}$} \\
\hline & & Range & Mean \\
\hline $\begin{array}{l}\text { Miocene rhyolite intrusives ........................... } \\
\text { Middle Tertiary intermediate- }\end{array}$ & 3 & $0.1-0.9$ & 0.6 \\
\hline $\begin{array}{l}\text { composition intrusives } \\
\text { Cretaceous intrusives }\end{array}$ & 11 & $\begin{array}{c}3.6-10.9 \\
1.4\end{array}$ & $\begin{array}{l}6.1 \\
1.4\end{array}$ \\
\hline
\end{tabular}

$1 K=$ apparent volume magnetic susceptibility in $\mathrm{emu} / \mathrm{cm}^{3}$ (electromagnetic units per cubic centimetres) measured with an induction-type apparatus.

Most middle Tertiary intrusives of intermediate composition have high magnetic susceptibilities. The granodioritic to gabbroic intrusive rocks ranged in magnetic susceptibility from $3.6 \times 10^{-3}$ to $10.9 \times 10^{-3} \mathrm{emu} / \mathrm{cm}^{3}$ indicating a magnetite content of 1.3 percent by volume (Lindsley and others, 1966). The high susceptibility of the measured samples is verified by the aeromagnetic highs observed over the Mount Sneffels intrusive (anomalies A and B, fig. 3) and other intrusives marked by the large amplitude anomalies shown in the southwest corner of figure 3. Some of the monzonite intrusives exposed within the Uncompahgre Primitive Area and contiguous study areas, such as the altered plug at Matterhorn Peak, have a lower aeromagnetic expression than the intermediate intrusive rocks mentioned above. The monzonites do not contrast significantly with the surrounding ash-flow units and are difficult to recognize on the aeromagnetic map.

Three samples of the Miocene rhyolite intrusives measured for magnetic susceptibility indicate a moderate susceptibility with a mean of about $0.6 \times 10^{-3} \mathrm{emu} / \mathrm{cm}^{3}$. This moderate susceptibility is evident on the aeromagnetic map as the rhyolite intrusives exhibit no magnetic contrast where they are surrounded by tuffaceous rocks, but they cause aeromagnetic lows when contrasted with near-vent intermediate-composition flows.

Within the primitive area, the early intermediate-composition near- 
vent facies rocks display high susceptibilities similar to those of the early intrusives. Of the three samples measured (table 10), the high was $6.7 \times 10^{-3}$ $\mathrm{emu} / \mathrm{cm}^{3}$ and the mean was $4.7 \times 10^{-3} \mathrm{emu} / \mathrm{cm}^{3}$, indicating that these rocks, given sufficient thickness relative to their distance from the detector, could cause significant anomalies. The 10 samples of volcaniclastic facies early intermediate rocks measured had a broad range in susceptibility but averaged about $0.8 \times 10^{-3} \mathrm{emu} / \mathrm{cm}^{3}$. These rocks would be expected to produce only low-amplitude anomalies.

The flows of intermediate composition in the Henson and Burns Formations and the welded ash-flow tuffs in the Ute Ridge Tuff showed moderate to high susceptibilities, confirming the observation that these volcanic flows can produce significant anomalies where they are sufficiently thick on topographic highs. Measurements of Sapinero Mesa Tuff indicated that this unit was low in susceptibility.

TABLE 10.-Magnetic measurements of volcanic flows, breccias, and welded tuffs, Uncompahgre Primitive Area and surrounding areas

\begin{tabular}{|c|c|c|c|}
\hline \multirow{2}{*}{ Rock type } & \multirow{2}{*}{$\begin{array}{l}\text { Number of } \\
\text { samples }\end{array}$} & \multicolumn{2}{|c|}{$1 K \times 10^{-3}$} \\
\hline & & Range & Mean \\
\hline Henson and Burns Formations... & 5 & $0.1-1.5$ & 1.3 \\
\hline Sapinero Mesa (and Eureka Member) Tuft... & 3 & $.0-.7$ & .2 \\
\hline Ute Ridge Tuff & 1 & 4.1 & $\ldots .$. \\
\hline \multicolumn{4}{|l|}{ Early intermediate-composition rocks: } \\
\hline 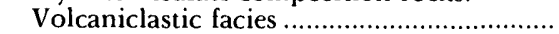 & 10 & $.1-2.7$ & .8 \\
\hline 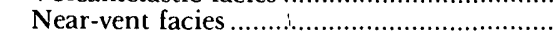 & 3 & $2.5-6.7$ & 4.7 \\
\hline
\end{tabular}

\section{WESTERN UNCOMPAHGRE PRIMITIVE AREA} AND WESTERN CONTIGUOUS STUDY AREA

The aeromagnetic expression of the western contiguous area is dominated by a magnetic high with an amplitude of 800 gammas above the regional level in the vicinity of the intrusive stock underlying Mount Sneffels (anomaly A, fig. 3), and a similar high of 600 gammas above the regional level near the stock on the north side of Iron Mountain and Campbell Peak (anomaly B, fig. 3). Gabbro from Mount Sneffels measured for magnetic properties showed the rock to be highly magnetic $\left(10.0 \times 10^{-3} \mathrm{emu} / \mathrm{cm}^{3}\right)$, which fact would cause high-amplitude anomalies. The broad gradient on the south side of anomalies $A$ and $B$ and the amplitude of the anomalies indicates that both stocks extend to considerable depths and suggests that they may be connected. The arcuate pattern of the anomaly probably reflects the shape of the intrusive body at depth, indicating emplacement along an arcuate fracture zone, but gradients are locally steepened by the influence of intrusive dikes occurring in swarms near the topographic highs and by thick near-vent flows. The laccolith at Whipple Mountain, owing to its limited thickness in relation to its 
distance from the detector, causes only a 60 -gamma deflection of the gradient contours. North of the highs associated with the stocks at Mount Sneffels and Campbell Peak (anomalies A and B) are induced dipolar lows (anomalies $C$ and $D$ ).

A magnetic high marked by a peak value of 1,024 gammas occurs north of the western contiguous area. The high is associated with an Upper Cretaceous intrusive sill of intermediate composition that crops out in the northwestern part of the western contiguous area northwest of Ouray and in the area of the Dallas Divide, not identified on the map but $2 \frac{1}{2}$ miles (4 $\mathrm{km}$ ) north of the contiguous area. The continuity of the magnetic anomaly suggests that this sill underlies the entire area north of the western contiguous area. The linear gradient along the south side of the anomaly suggests that the sill's emplacement may have been partially controlled by an east-trending fault.

\section{CENTRAL UNCOMPAHGRE PRIMITIVE AREA AND CENTRAL CONTIGUOUS STUDY AREA}

The aeromagnetic map to the south and southwest of Ouray is characterized by a broad bifurcated low of about 100 gammas below the regional level (anomalies $E$ and $F$, fig. 3). The low appears to be caused by a composite effect of topography and a thin section of volcanic rocks, as one limb follows the Un€ompahgre River and Red Mountain Creek to the vicinity of Ironton. (See Burbank and Luedke, 1964, for detailed geology and topography.) The other limb follows a deep canyon southwest, crosses the topographic divide, and extends to the vicinity of Telluride over the canyon of the San Miguel River (anomaly F, fig. 3). South of Ouray Precambrian quartzites are exposed along the Uncompahgre River in the upthrown block of a fault shown as the Ouray fault by Luedke and Burbank (1962, sec. $\left.B-B^{\prime}\right)$. North of the fault sedimentary rocks are exposed at the surface underlain by Precambrian quartzite known, from exposures in mine workings (Luedke and Burbank, 1962), to have a thickness of at least 3,300 feet $(1 \mathrm{~km})$. In the vicinity of Telluride, volcanic rocks are also absent, as the San Miguel River is deeply eroded into lower Tertiary and pre-Tertiary sedimentary rocks.

Several lines of evidence, however, suggest that the bifurcated low is not entirely due to topography and an absence of volcanic rocks. The Ouray fault is marked by a magnetic gradient with a low to the south, yet the thickest quartzite and sedimentary rocks lie north of the fault. The low is closed on the west at Telluride and its deepest part is east of Telluride, yet the area of greatest topographic relief and sedimentary section is west of Telluride. The low crosses volcanic rocks on the topographic divide that are known to be moderately magnetic in other areas, yet in this area they are apparently nonmagnetic. This fact, coupled with the fact that the low overlies rocks that are moderately to intensely altered and mineralized and crosses the generally northwest-trending veins in the area through their 
most productive segments, suggests that the low' marks an area of intense hydrothermal alteration where the original magnetite content of the volcanic rocks has been destroyed by leaching. This suggestion is supported by low measured susceptibilities of altered early intermediatecomposition volcaniclastic rocks from the main mine area.

\section{EASTERN UNCOMPAHGRE PRIMITIVE AREA AND EASTERN CONTIGUOUS STUDY AREA}

The eastern part of the Uncompahgre Primitive Area and the eastern contiguous study area are characterized by a broad magnetic high that increases in steplike plateaus to maxima that extend from the divide southwest of Wetterhorn Peak northeastward and eastward to Crystal Peak (anomalies G, H, I, J, fig. 3). North of this peak-studded magnetic plateau, the magnetic pattern is characterized by a broad east-west low and local north-south lows over the West (anomaly K), Middle (L), and East Forks Cimarron River (M), Little Cimarron River (N), and Fall (O), Blue (P), and Elk Creeks (Q). The magnetic plateau is closely coincident with an area of high topography chiefly underlain by thick, early intermediate-composition flows (near-vent facies), Ute Ridge Tuff, and volcanics of Uncompahgre Peak. The high crosses diverse geologic units and is of sufficient magnitude to suggest a cause that is not evident in surface geology. The steepness of the east-west gradient separating the high from the low to the north suggests that much of the high is caused by a mass whose top lies at or above 9,000 feet $(2,700 \mathrm{~m})$ altitude or only a shallow distance beneath the surface.

All the early intermediate-composition intrusives exposed within the Uncompahgre Primitive Area and eastern contiguous area lie within the high or along its northern gradient, although the individual mapped intrusives do not produce characteristic highs similar to the intrusives at Mount Sneffels (anomaly A), Sultan Mountain, and elsewhere. Four possibilities may account for this fact: (1) The stocks in the eastern area are all somewhat altered and have had much of the original magnetite destroyed, (2) the thick lava flows capping the peaks and divides do not differ significantly in susceptibility from their related stocks, (3) topographic relief placed the relatively magnetic flow rocks near the magnetometer, causing localized high intensity anomalies, which may mask anomalies resulting from susceptibility contrast and greater thickness, and (4) the entire area may be underlain by Tertiary intrusives, and the exposed intrusives are not representative of their volume at depth.

The positive anomaly over Sheep Mountain (anomaly R, fig. 3) in the northwest part of the eastern contiguous area points up the high susceptibility of many of the near-vent facies flows. This anomaly stands out sharply within the general magnetic low in the northern half of the contiguous area. Sheep Mountain is capped by a single lava flow about 
1,000 feet $(300 \mathrm{~m})$ thick. An analysis of the anomaly, assuming a contrast of $460+$ gammas with the regional level, shows that this flow would need a susceptibility contrast of more than $13 \times 10^{-3} \mathrm{emu} / \mathrm{cm}^{3}$ to match the observed values, thus requiring that the flow have a higher susceptibility than any of the sampled intrusives. Depth analysis shows that the anomaly originates at or near ground level. No exposures of intrusive rocks are known to exist in the area. The highs and lows along the northern profiles line up closely with topography, suggesting that the lava flow capping the ridge is the source of the Sheep Mountain anomaly. The series of lows located over the stream valleys is , therefore, caused by topography and edge effects of the more magnetic body capping the ridge. A similar positive anomaly caused by near-vent facies early intermediate flows capping a ridge is located northeast of Sheep Mountain and is marked by a peak of 894 gammas on the aeromagnetic map.

The overall magnetic buildup in the eastern part of the Uncompahgre Primitive Area and eastern contiguous area, and the broad low that is developed to the north, however, must originate partly from a deeper source. The localized anomalies with steep gradients undoubtedly reflect shallow sources-probably the near-source lava flows and volcaniclastic sediments exposed at the surface-but these are superimposed on a more general widespread moderate-amplitude anomaly. This deeper source may be a relatively mafic facies of the parent batholith that underlies the San Juan Mountains (Plouff and Pakiser, 1972) from which the Matterhorn, Cimarron, and Larson volcanoes originated. The broad regional magnetic low that lies in the northern half of the central and eastern contiguous areas may be the dipole effect of this deeper source.

The localized anomaly of $1,800+$ gammas over Wetterhorn Peak (anomaly $\mathrm{H}$, fig. 3), which is capped by the Ute Ridge Tuff, is probably entirely related to topographic elevation of a relatively magnetic flow, as is anomaly $\mathrm{G}$ to the south. The magnetic high marked by a maximum value of 1,728 gammas northeast of Uncompahgre Peak (anomaly I, fig. 3) similarly occurs over one of the largest knots of high topography in excess of 13,000 feet $(4,000 \mathrm{~m})$ in the western San Juan Mountains; the peaks are capped by thick, near-vent facies early intermediate-composition flows and are intruded by early intermediate-composition intrusives. The isolated magnetic high marked by 1,299 gammas (anomaly J, fig. 3) occurs over a thick section of intermediate-composition flows and breccias capping Crystal Peak.

The northeast-trending segment of caldera fill that overlies the structural margin of the Uncompahgre caldera north of Henson Creek does not exhibit a recognizable aeromagentic pattern, nor do the rhyolite intrusives that are emplaced along it. Samples of two of these intrusives measured for magnetic properties averaged a low susceptibility of 0.0006 $\mathrm{emu} / \mathrm{cm}^{3}$. This value is not significantly different from that of many of 
the measured samples of tuffaceous rocks that fill the Uncompahgre caldera and into which these rhyolites were intruded.

Four closed aeromagnetic lows occur in or near the eastern part of the Uncompahgre Primitive Area; these may be related to areas of alteration and thus have economic significance as exploration targets. One low occurs east of Matterhorn Peak (anomaly S, fig. 3) in the headwaters of the East Fork Cimarron River in an area of altered rocks containing anomalous concentrations of metals associated in part with the Matterhorn volcano and in part with the altered area at Iron Beds. Another closed low occurs across the topographic divide in the drainage of Henson Creek (anomaly T, fig. 3) and is a part of the Capitol City mining area. This anomaly lies near the structural margin of the Uncompahgre caldera in an area that shows high copper and zinc values.

A third very small closed low (anomaly $U$, fig. 3) occurs between El Paso and Pole Creeks adjacent to the Capitol City mining area. This area is cut by the metalliferous veins whose anomalous metal content was indicated by both the $\mathrm{CxCu}$ and $\mathrm{CxHM}$ chemical tests described earlier in the geologic section of this report. An untested, closed low (anomaly V, fig. 3) occurs in the headwaters of Slaughterhouse Gulch above Lake City. This area was not sampled for metal values, but it occupies a position similar to that of the Capitol City mining area relative to the structural margin and associated intrusives of the Uncompahgre caldera.

\section{ECONOMIC APPRAISAL}

By C. L. Bieniewski and H. C. Meeves, U.S. Bureau of Mines

\section{MINING CLAIMS}

Land-status records of the U.S. Bureau of Land Management were examined to determine existing patented mining claims, and the records of Hinsdale, Gunnison, Ouray, and San Miguel Counties were examined to determine the unpatented mining claims in and near the three contiguous areas. These examinations revealed 525 patented claims and approximately 4,300 unpatented claims in the area investigated. Of these, 93 patented and approximately 3,000 unpatented claims are within the contiguous areas. The locations of the patented claims, shown on plate 3 , are taken from master title plats of the U.S. Bureau of Land Management; the locations of the unpatented claims are based on claim descriptions of the recorded location notices and on maps from individuals or companies. The configurations and locations of the unpatented mining claims are only approximations, for many of these claims were not clearly described. In addition, many unpatented areas have been restaked at different times, and claims shown on plate 3 represent only part of the total number of unpatented claims that have been recorded. 


\section{SAMPLING}

All mineralized areas in the contiguous study areas were examined and sampled duirng this investigation. If numerous workings were dug in a closely spaced area, commonly, only selected ones were sampled. All sample localities are shown on plate 3 .

Most of the underground workings at the old mines and prospects were inaccessible because of caving or flooding. At such places, dumps and surface exposures of veins, fractures, dikes, or similar structures were sampled. If the workings. were accessible, samples were taken underground on structures and at the face of the adit or drift. In a few places, samples were taken of stream sediments and of sand and gravel deposits.

Chip samples weighing 1-3 pounds (0.45-1.4 kg (kilograms)) were taken at accessible underground workings and rock outcrops. On dumps, grab samples of $1-5$ pounds $(0.45-2.3 \mathrm{~kg})$ were taken on a grid system. In a few instances, material considered to represent the dump was selected. Samples from streams were either grab samples of sediments or panned concentrates.

All but two samples were fire assayed for gold and silver and were analyzed spectrographically for 40 elements. Some were further analyzed by other methods for specific elements. The results of all analyses are shown in table 11. One sample of limestone and two samples of coal were analyzed to determine their economic value; the results of these analyses are shown in tables 12 and 13 , respectively.

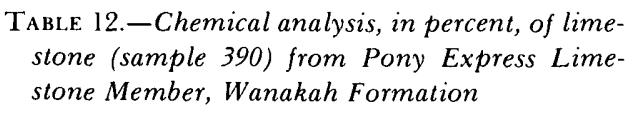

\begin{tabular}{|c|c|}
\hline alcium carbonate $\left(\mathrm{CaCO}_{3}\right) \ldots \ldots \ldots$ & 92.1. \\
\hline $\left.\mathrm{O}_{2}\right)$. & \\
\hline $\mathrm{le}\left(\mathrm{Fe}_{2} \mathrm{O}_{3}\right)$ & \\
\hline ․․․․…………… & $\begin{array}{r}1.28 \\
51.35\end{array}$ \\
\hline Magnesia (MgO) & .73 \\
\hline$m$ oxide $\left(\mathrm{TiO}_{2}\right) \ldots$ & \\
\hline ........... & 40.84 \\
\hline & .13 \\
\hline
\end{tabular}

\footnotetext{
'The percentage of calcium carbonate $\left(\mathrm{CaCO}_{3}\right)$ is calculated by adding the lime $(\mathrm{CaO})$ and the volatile matter, which may be considered as carbon dioxide $\left(\mathrm{CO}_{2}\right)$.
}

\section{HISTORY AND MINERAL PRODUCTION}

The history of the mining activity and mineral production in an adjacent to the Uncompahgre Primitive Area up to 1966 was discussed by Fischer, Luedke, Sheridan, and Raabe (1968). The history of the Lake City area was discussed in detail by Irving and Bancroft (1911). Since 1966, 
TABLE 13.-Analyses of coal, in percent, from west of San Miguel

\begin{tabular}{|c|c|c|}
\hline 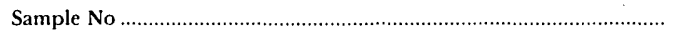 & 359 & 360 \\
\hline \multicolumn{3}{|l|}{ Proximate analysis: } \\
\hline 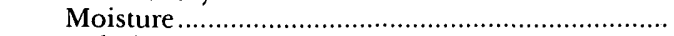 & 1.5 & 1.0 \\
\hline (1) & 8.8 & 10.2 \\
\hline 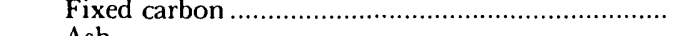 & 37.3 & 32.6 \\
\hline ……........... & & \\
\hline Total.. & 100.0 & 100.0 \\
\hline \multicolumn{3}{|l|}{ Ultimate analysis: } \\
\hline Hydrogen. & 2.1 & 2.2 \\
\hline Carbon ...... & 40.4 & 35.5 \\
\hline Nitrogen & .7 & .6 \\
\hline Oxygen & 3.9 & 5.1 \\
\hline 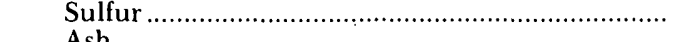 & .5 & .4 \\
\hline & & \\
\hline 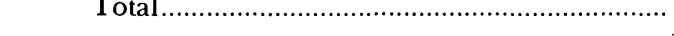 & 100.0 & 100.0 \\
\hline British thermal uni & 570 & 5,470 \\
\hline
\end{tabular}

activity in the contiguous study areas discussed here has consisted mainly of claim location, assessment work, and exploration.

According to U.S. Bureau of Mines records, the only recorded mineral production during 1966-71 from within the contiguous areas was for stone produced in Gunnison County in 1969 and 1970 from two quarries on the east side of the Middle Fork Cimarron River. The northern quarry is $1 \frac{1}{2}$ miles $(2.4 \mathrm{~km})$ south of the junction of the East and Middle Forks; the other quarry is 1 mile $(1.6 \mathrm{~km})$ farther south. The stone was used for riprap in construction of the Silver Jack Dam on the Cimarron River (not shown on plates).

Gold, silver, copper, lead, zinc, limestone, and sand and gravel were produced during 1966-71 from mines near the contiguous areas. The precious- and base-metal production was from the Ute-Ulay (1966-68) and Capitol City (1968) mines in Hinsdale County; the Senorita (1966); Bachelor-Syracuse (1968-70), and Portland (1968) mines in Ouray County; and the Courthouse (1966) mine in San Miguel County. Limestone was quarried at the mouth of Deep Creek in San Miguel County from 1969 through 1971, and it was used at the Union Carbide Corp. uranium mill at Uravan, Colo., to neutralize plant effluent. Sand and gravel, obtained near the junction of the East Fork and West Fork Cimmarron River in 1969; was used in constrücting the Silver Jack Dam (not shown on plates).

Exxon Corp. (1971-72) and Greater West Mining Co. (1969) have explored for uranium in the eastern contiguous area and adjacent parts of the original primitive area, and Dixilyn Corp. (1971) explored for molybdenum in the headwaters of the East Fork Cimarron River adjacent to the eastern contiguous area. Other exploration work was done by Eric 
Benson (1960) for manganese in the eastern contiguous area, by Hughes Mining Co. (1966-69) for silver, lead, and zinc at the Ute-Ulay mine near the eastern contiguous area, and by Baumgartner Oil Co. (1971-72) for copper in the central contiguous area and adjacent parts of the Uncompahgre Primitive Area. In addition, assessment work on unpatented mining claims was done by other companies and individuals.

\section{LEASING ACT MINERALS}

All oil and gas leases that had been issued for land in or within 5 miles ( 8 $\mathrm{km}$ ) of the contiguous study areas were cancelled or terminated before 1972; no holes had been drilled. Twelve holes were drilled on private land in T. 45 N., R. 8 W., New Mexico Principal Meridian. The nearest hole to the study area is a dry hole that lies about 1 mile $(1.6 \mathrm{~km})$ west of the boundary of the central contiguous area in the $\mathrm{SE}^{1 / 4} \mathrm{SW}^{1 / 4} \mathrm{sec}$. 35; the hole was spudded in the Cutler Formation and abandoned in the Hermosa Formation. Two holes in SE1/4 SW1/4 sec. 11 and in NE1/4 NE1/4 sec. 15 yielded a small amount of natural gas from the Dakota Sandstone. The location of 8 of the 12 holes is shown on plate $3 A$; the other 4 holes are located in

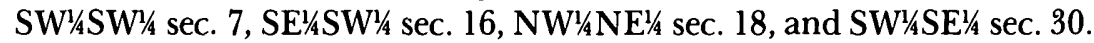

Coal-entry patents have been granted, and coal leases and coal permits have been issued for parcels of land in T. 46 N., Rs. 6 and 7 W., several miles northwest of the eastern contiguous area; none is within the contiguous areas. Many of the leases and permits have been cancelled or terminated, but Kemmerer Coal Co. controls some of the active leases and permits and has acquired leases for some private lands. Since 1964, the company has done considerable exploration work for coal on these properties, and in 1972 it was considering development of its coal west of Cimarron Ridge. The coal occurs in the Fruitland Formation in the southern part of the Tongue Mesa coal field. Landis (1959) estimated the reserve of this field at 2,355 million tons of subbituminous coal.

The northeasterly trending Ridgway fault that passes about 5 miles ( 8 $\mathrm{km}$ ) northwest of the eastern contiguous area limits the Tongue Mesa coal field on the south. To the southeast, however, some of the Fruitland Formation may be covered by landslides, glacial deposits, and Tertiary volcanic rocks near the northern boundary of the study area in the vicinity of Cimarron Ridge.

\section{MINES, PROSPECTS, AND MINERALIZED AREAS}

Most of the study area is covered by Tertiary volcanic rocks, and intrusive bodies of Tertiary age are exposed throughout the area. Paleozoic and Mesozoic sedimentary rocks and the Telluride Conglomerate of Tertiary age are exposed in the central contiguous area. Mesozoic sedimentary rocks and the Telluride Conglomerate crop out in the western contiguous area, but no sedimentary rocks are exposed in the eastern contiguous area. Many of the formations have been fractured and structurally deformed. 


\section{WESTERN CONTIGUOUS AREA}

The western contiguous area is north and west of the western part of the Uncompahgre Primitive Area. The 45 square miles $\left(115 \mathrm{~km}^{2}\right)$ that compose the area are almost equally divided between Ouray and San Miguel Counties.

The western contiguous study area borders one of the most highly mineralized areas in Colorado, and numerous claims have been staked in and near it. The claims are most numerous near the southeastern part of the contiguous area where the large productive veins east of Telluride extend toward and in part into the area ( $\mathrm{pl} .3 B$ ). Some of the veins probably contain potential resources at depth. Another group of claims is concentrated near Whipple Mountain in the western part of the contiguous area where many small veins are associated with a laccolithic intrusive center. The economic potential of this area, however, seems low. A third group of claims lies mostly outside the contiguous area between the Uncompahgre River and the northeastern part of the contiguous area where many veins are associated with sills and laccoliths on the west flank of a mineralized intrusive center located just north of the town of Ouray. Some of the mineralized rock from this area may have economic potential. Many other claims are scattered throughout the western contiguous area; mineralized rock was evident on some of these, but many claims appear devoid of significant mineral deposits.

\section{PLUMMER GULCH}

The Millersburg property is a about one-half mile $(0.8 \mathrm{~km})$ southeast of Plummer Gulch, near the eastern end of the western contiguous area (pl. $3 B)$. Three adits were driven west along a 4-foot $(1.2-\mathrm{m})$ fault zone that is possibly the western extension of the Black Girl vein. The lowest adit, driven in the Morrison Formation, is inaccessible. The middle adit (fig. 4) is near the Morrison-Dakota contact; it is approximately 75 feet $(23 \mathrm{~m})$ higher on the steep slope and is 170 feet $(52 \mathrm{~m})$ long. The highest adit, approximately 150 feet $(46 \mathrm{~m}$ ) above the middle adit, was driven 65 feet (20 $\mathrm{m}$ ) into the Dakota Sandstone. Other nearby workings are an adit, now caved, that was driven into the Dakota Sandstone and a small prospect pit exposing narrow quartz-clacite stringers in the Dakota Sandstone about one-half mile $(0.8 \mathrm{~km})$ west of the caved adit.

The workings on Plummer Gulch (fig. 5$)$, about 1 mile $(1.6 \mathrm{~km})$ west of the Uncompahgre River (pl. $3 B$ ), consist of two connecting adits, one of which is caved. The main adit was driven northwest 300 feet $(90 \mathrm{~m})$ along the Morrison-Dakota contact.

Of the samples collected in the Plummer Gulch area, only those from the Millersburg property were significantly mineralized. A $1-$ foot $(0.35-\mathrm{m})$ vein in a 2.5 -foot $(0.76-\mathrm{m})$ fault zone at the intersection of narrow cross veins is exposed in the back of the Millersburg middle adit. Chip samples 260 and 261 (table 11) taken across the vein assayed 45.1 and 38.0 ounces of 


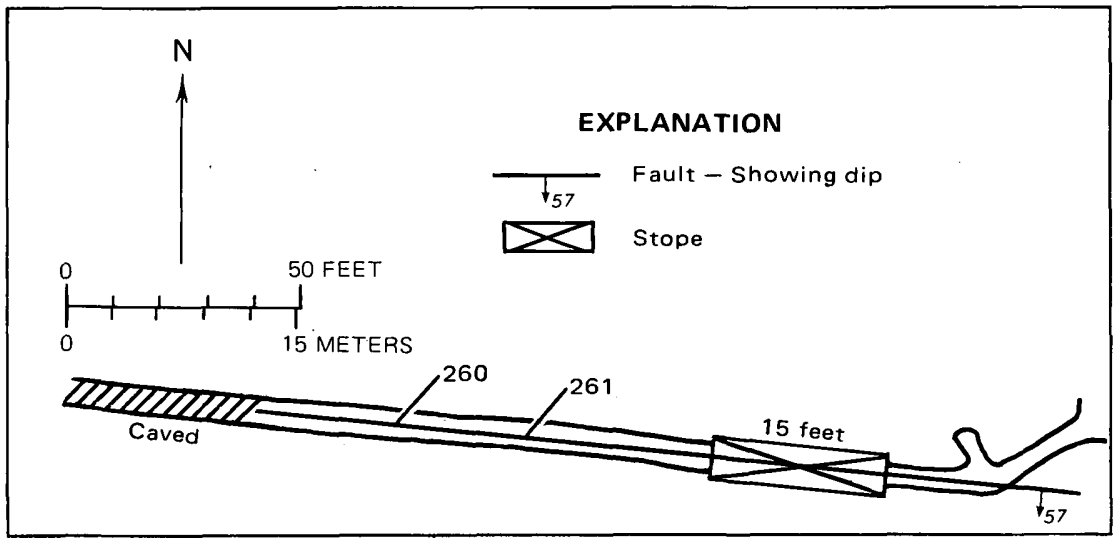

FIGURE 4.-Map of the Millersburg middle adit showing sample localities 260 and 261.

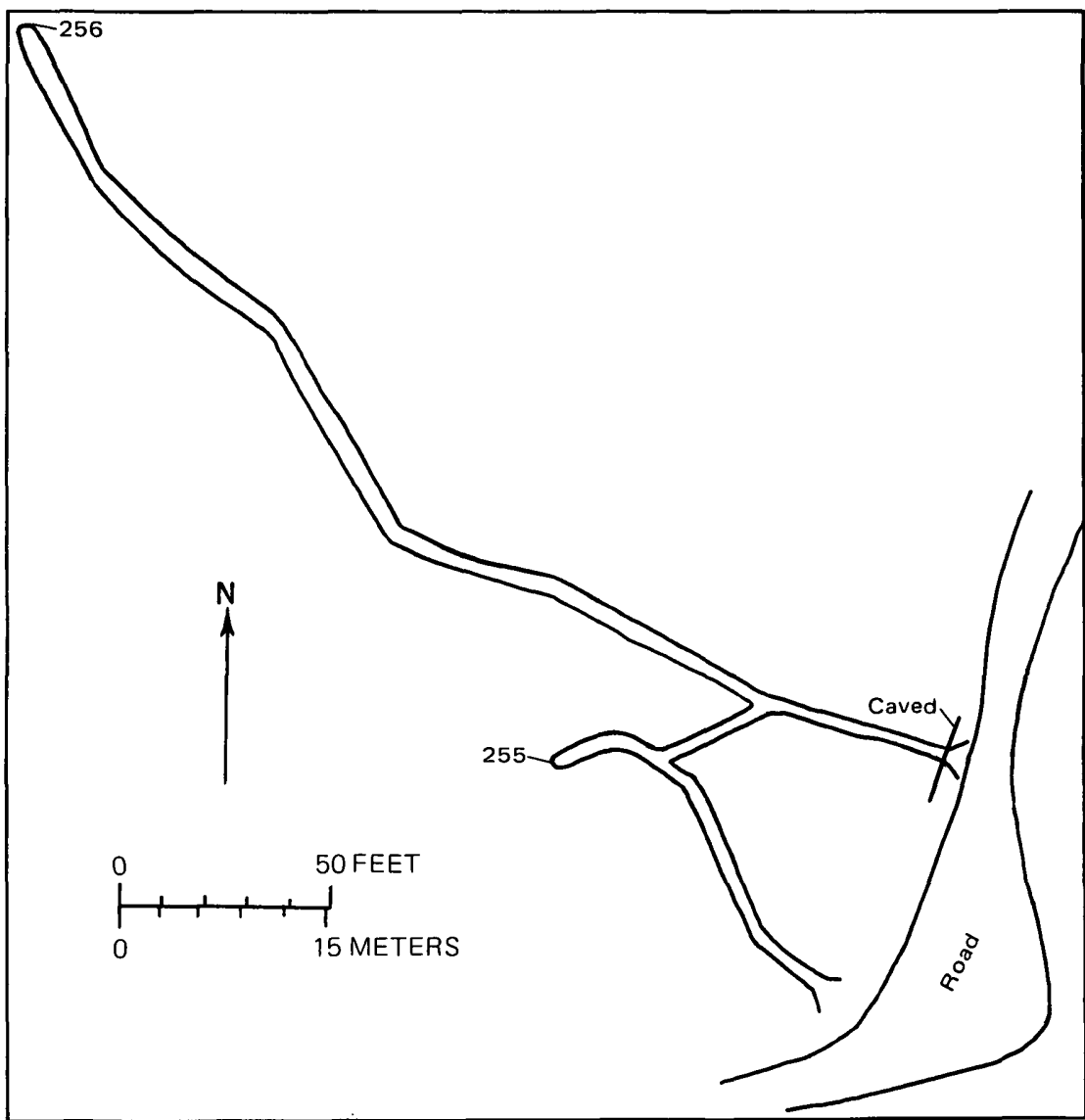

FigUre 5.-Map of the Plummer Gulch adit showing sample localities 255 and 256. 
silver per ton, 3.25 and 2.74 percent copper, and small amounts of lead, zinc, arsenic, and antimony.

Grab samples 262 and 263 taken from the dump at the lowest Millersburg adit contained, respectively 4.8 and 1.6 ounces of silver per ton, and small amounts of copper, lead, gold, and antimony.

\section{MOONSHINE PARK}

On the west edge of Moonshine Park in the eastern part of the western contiguous area, a shaft was sunk on a contact between quartzite and diorite porphyry; the shaft is now inaccessible. Sample 264 (table 11) from the dump assayed 0.1 ounce of silver per ton.

About one-half mile $(0.8 \mathrm{~km})$ south of Moonshine Park, on the crest of a north-trending ridge, a small prospect pit exposes narrow calcite-quartz stringers in porphyritic andesite. Analyses of sample 265 from the dump of the pit showed no metals of interest.

\section{FORCEMAN CREEK}

Just south of Forceman Creek and east of the western contiguous area, a number of workings were driven west in the Wanakah and Morrison Formations. Workings range from prospect pits to inaccessible adits and include the Little Gem mine, which has a 5,000-ton (4,500-t) dump. Generally the openings appeared to have been driven either along or in search of the productive Newsboy-Black Girl-Senorita vein systems that have been mined on the east side of the Uncompahgre River.

The only significant metal values are those of samples $267-270$ and 274-275 (table 11) which assayed from a trace to 4.3 ounces of silver per ton and from 0.06 to 1.44 percent copper; samples 269 and 270 contained some antimony.

\section{CORBETT CREEK}

Along Corbett Creek and its two tributaries, Pryor and Omaha Creeks, adjacent to the eastern part of the western contiguous area (pl. 3B), prospect pits, shafts, and adits were dug in the Morrison Formation and along the Morrison-Dakota and the Dakota-Mancos contacts. Most workings follow northwest-trending barite veins that dip steeply to the southwest; the veins contain galena, sphalerite, chalcopyrite, proustite, and tetrahedrite. Samples 276-289 were taken at these workings, and samples 295 and 296 were taken from outcropping veins in Corbett Creek above its junction with Pryor Creek. Except for samples 279, 288, and 289, the analyses indicated little metal of significance (table 11). Sample 279, a grab sample from a 2,000-ton (1,800-t) dump at the caved Chinaman adit, assayed a trace of gold, 1.9 ounces of silver per ton, 1.11 percent lead, and 0.23 percent zinc. Sample 288 , from a 500 -pound $(226-\mathrm{kg})$ stockpile at the caved Teller adit, assayed a trace of gold, 3.1 ounces of silver per ton, 8.57 
percent lead, and 4.86 percent zinc. Sample 289 , from a 300 -pound (130$\mathrm{kg}$ ) stockpile at the caved Sequin adit, assayed a trace of gold, 1.3 ounces of silver per ton, 2.55 percent lead, and 1.15 percent zinc.

About one-fourth mile $(0.4 \mathrm{~km})$ east of upper Forceman Creek, five adits, within a horizontal distance of 210 feet $(64 \mathrm{~m})$, were driven west in the upper part of the Morrison Formation. The adits are largely caved except for one which is accessible for about 50 feet $(15 \mathrm{~m})$ from the portal. The adits are on the projection of the Little Gem-Pony Express veins system which appears to horsetail in this area. Manganese-stained barite, galena, sphalerite, tetrahedrite, and argentite were identified in material from the dumps.

Sample 290 , from an 800 -pound $(363-\mathrm{kg})$ stockpile, and sample 292, from a 1,000-pound (454-kg) stockpile, assayed, respectively, 20.8 and 9.8 ounces of silver per ton, 2.00 and 1.75 percent lead, and 4.29 and 4.62 percent zinc; sample 292 contains 0.2 ounce of gold per ton. Samples 291, 293, and 294 were taken at the accessible adit; sample 291, taken from a muck pile in a stope, assayed 1.6 ounces of silver per ton, 0.99 percent lead, 1.08 percent zinc, and 0.03 percent antimony, but analyses of other samples showed only small amounts of silver, lead, and zinc.

\section{CORNET CREEK-PACK BASIN-MILL CREEK BASIN}

Several old mines and numerous prospect workings were dug in the Cornet Creek-Pack Basin-Mill Creek basin area in the southeastern part of the western contiguous area (pl. 3B). The Liberty Bell mine, at the head of Cornet Creek, produced 2.3 million tons of ore valued at $\$ 16$ million during 1898-1921; less than 3,000 tons was shipped during 1922-35. Except for a small amount of copper and lead, only gold and silver were recovered. No ore production has been reported since 1935 .

Figure 6 shows the underground workings of the largest mines (Liberty Bell, Smuggler-Union, Humboldt, and Mountain Top) and their relation to the western contiguous area. Since 1901, these mines have yielded ore valued at $\$ 79.2$ million, with most of the value coming from gold and silver. In addition, copper, lead, and zinc were recovered from the Smuggler-Union ores, copper and lead from the Mountain Top ores, and lead from the Humboldt ores. The most recent activity in the district was in 1967-71, when exploration for silver, partly financed by the Office of Mineral Exploration (OME), was done at the Mountain Top mine. No ore was found but the work disclosed some precious- and base-metal mineralization.

The only accessible underground workings in the area are three prospect adits, shown in figures 7, 8, and 9. Sample groups 329-335 and 341-346 were taken at these workings. Analyses of samples 329-335 show small amounts of gold, silver, copper, and lead (table 11). Samples $317-328,336-340$, and $347-358$ also were taken in the area, but the only 


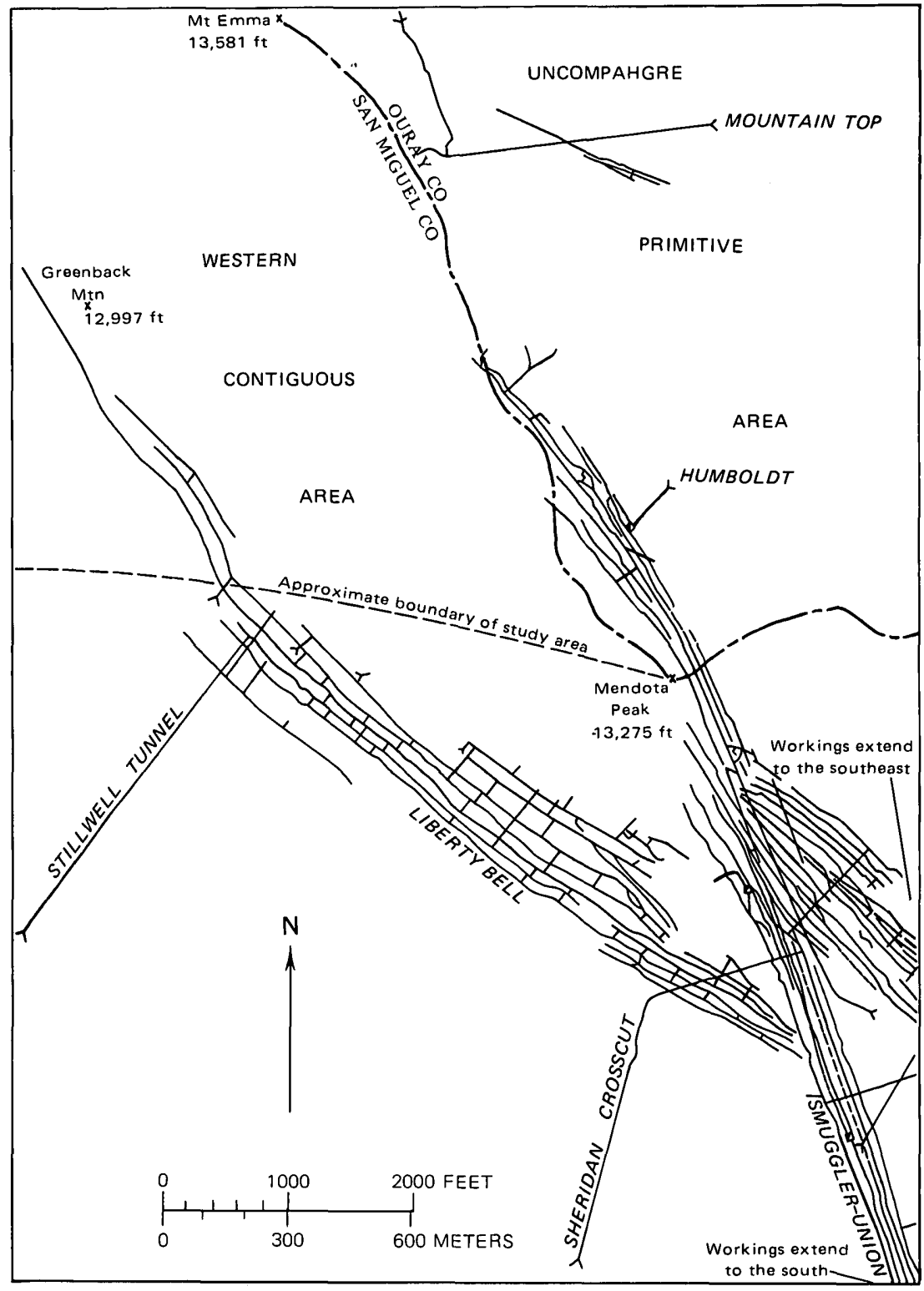

FIGURE 6.-Main underground mine workings in and near the southeast part of the western contiguous area. Modified from King and Allsman (1950, fig. 4a).

significant results came from sample 353 , a grab sample from the dump of a caved adit at the head of Cornet Creek, which contained 0.02 ounce of gold and 1.2 ounces of silver per ton. 


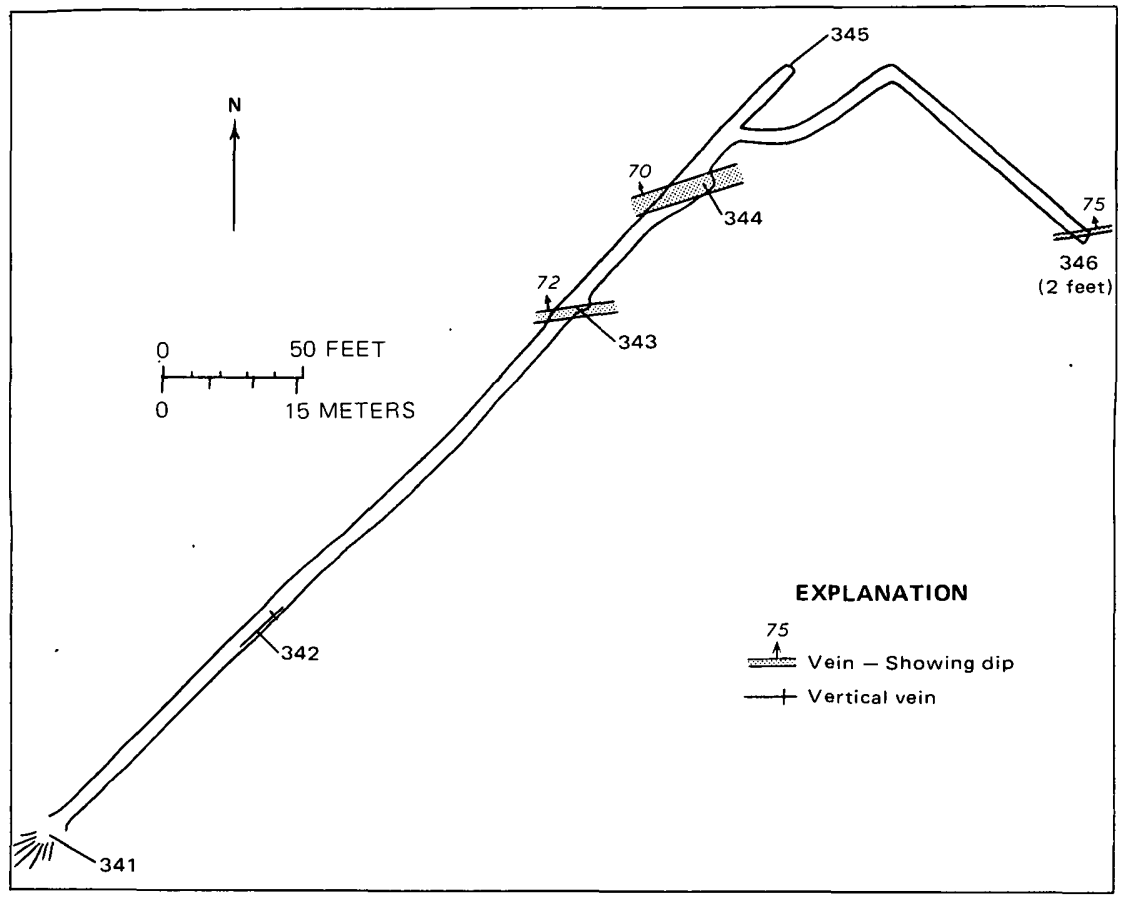

FIGURE 7.-Map of adit at head of Cornet Creek showing sample localities 341-346.

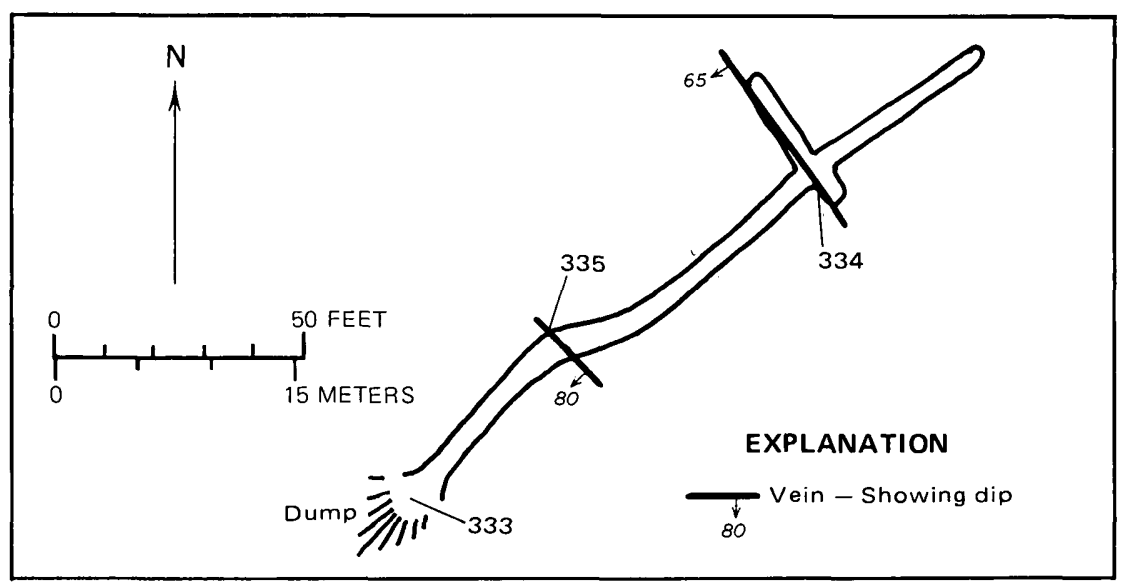

Figure 8.-Map of adit in Pack Basin showing sample localities 333-335.

SAN MIGUEL RIVER

Mesozoic sedimentary rocks, capped by the Telluride Conglomerate and by Tertiary volcanic rocks, are exposed in a strip of land about 2 miles $(3.2 \mathrm{~km})$ wide between the San Miguel River and southern boundary of the 


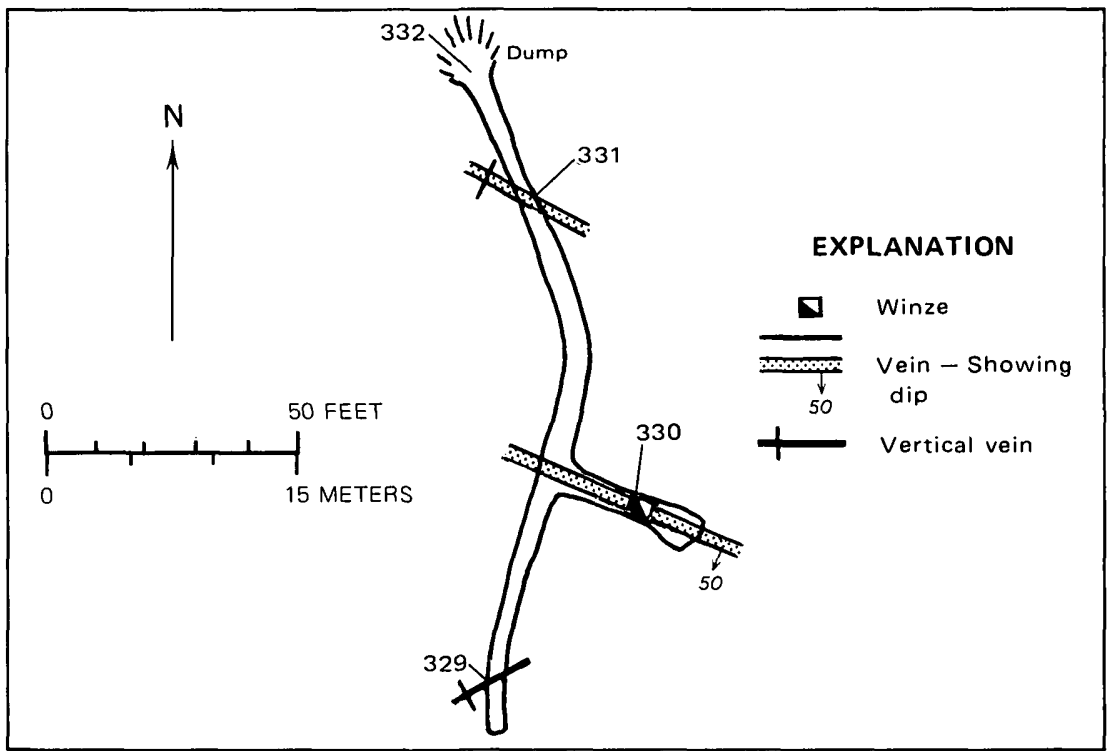

Figure 9.-Map of adit in Mill Creek basin showing sample localities 329-332.

western contiguous area (pl. $3 B$ ). Some ore has been produced from the area, but the only production recorded by the U.S. Bureau of Mines is for limestone that was mined in the late 1960's and early 1970's from a quarry at the mouth of Deep Creek. Gray-black limestone from the Pony Express Member of the Wanakah Formation was used to neutralize plant effluent at the Union Carbide Corp. uranium mill at Uravan, Colo. A chemical analysis of sample 390 from this location is shown in table 12 .

About one-fourth mile $(0.4 \mathrm{~km})$ north of the limestone quarry, underground workings were driven to explore a 6 -foot $(2-\mathrm{m})$ vein that crops out along the cliffs. According to the Colorado Bureau of Mines, lead-silver ore was produced in 1969 from these workings; Sharon Spencer, one of the operators, stated that the ore was mined from a vein in the Pony Express Member at the bottom of a 115 -foot $(40-\mathrm{m})$ shaft.

A small coal mine about $1 \frac{11}{4}$ miles $(2 \mathrm{~km})$ west of San Miguel near the top of the cliff on the north side of Colorado Highway 145 develops a coal seam in Dakota Sandstone. According to Frank Wilson of Telluride, the mine was operated in the 1880's and again about 1932; the coal was used for heating homes in the Telluride area. Sample 359 was taken across a 1.25-foot $(0.4-\mathrm{m})$ coal seam exposed about 6 feet $(2 \mathrm{~m})$ from the portal of the western adit. About one-half mile $(0.8 \mathrm{~km})$ west of the coal mine, a dump on the north side of Deep Creek Mesa road marks a nearly obliterated mine opening at the base of the Dakota Sandstone. Sample 360 consisted of a few selected pieces of coal from the dump. Analyses of samples 359 and 360 (table 13) indicated that the coal is poor quality. It 
should be noted that these samples are weathered and probably are not as good quality as the unweathered coal. Along Summit Creek some prospect pits were dug in the Dakota Sandstone in search of coal; dumps at the prospects indicate that little or no coal was found.

An old quarry on the north side of Colorado Highway 145 about 1 mile (1.6 km) west of San Miguel supplied stone used in constructing some of the old buildings in Telluride. Estimated from the size of the excavation, less than 100 tons $(91 \mathrm{t}$ ) of sandstone from the Morrison Formation was removed.

\section{HAYDEN PEAK}

Several unpatented mining claims have been located between Hayden Peak and North Pole Peak on an altered zone and on some dikes. No prospect workings were found, but stakes of the Vampire group of claims were found. Samples 381-384, taken from dikes and the alteration zone, assayed only a trace of gold and 0.1-0.2 ounce of silver per ton (table 11).

On the northeast side of Hayden Peak, three adits were dug at the base of a cliff where an east-trending shear zone is exposed. The upper and middle adits, about 100 feet $(30 \mathrm{~m})$ apart, were driven southwest for nearly 150 feet $(46 \mathrm{~m})$; both begin and end in talus. Sample 380 from the dump at the middle adit assayed a trace of gold and 0.1 ounce of silver per ton; no sample was taken at the upper adit because the dump rock was identical to that of the middle adit. The 300 -foot $(90-\mathrm{m})$ lower adit, 550 feet $(160 \mathrm{~m})$ east of the middle adit, penetrated talus for 40 feet $(12 \mathrm{~m})$; thereafter, it was driven in solid rock. Sample 379 of a 10 -inch $(0.3-\mathrm{m})$ vein that was cut about 230 feet $(70 \mathrm{~m})$ from the portal, and sample 378 , taken across the face of the adit, contain some amounts of gold and silver. Sample 377 of the 500-ton (450-t) dump contains a little silver.

\section{WHIPPLE MOUNTAIN}

The south slope of Whipple Mountain, between Summit and Willow Creeks in the western part of the western contiguous area, is covered with talus consisting mostly of granodiorite. The exposed side of the rock fragments are black-brown and are covered with green lichen. The demand for this lichen-covered "moss rock" for use as decorative stone in home construction has been increasing; thus, this talus slope represents a significant resource. Moss Rock Nos. 1-6 placer claims located in June 1972 cover part of the talus slope, and some moss rock has been removed recently from along the Last Dollar road, about one-fourth mile $(0.4 \mathrm{~km})$ southeast of the spring on Willow Creek. The claims are partly in the western contiguous area.

\section{LAST DOLLAR MOUNTAIN}

Several workings, ranging from small prospect pits to inaccessible adits, are on the north and south slopes of Last Dollar Mountain in the western part of the western contiguous area. Most of the workings are 
along contacts between the Mancos Shale and andesite porphyry sills. Altered rock occurs in steep, southeast-trending fracture zones. Analyses of samples 385-389, collected from Last Dollar Mountain, did not show metal concentrations of interest except for sample 389, which contained 0.15 ounce of gold per ton (5 ppm) (table 11).

\section{COAL CREEK}

Coal Creek flows north from Whitehouse Mountain into the Uncompahgre River. Near the head of the east fork of Coal Creek, about one-half mile $(0.4 \mathrm{~km})$ north of the Uncompahgre Primitive Area, a basalt dike trends N. $53^{\circ} \mathrm{E}$. in the San Juan Formation. The dike is about 6 feet $(1.8 \mathrm{~m})$ wide and is nearly vertical. A 2-foot-wide (0.6-m-wide) hematite-stained breccia follows the northwest side of the dike, and quartz-calcite veinlets are interspersed through the dike. Sample 298, a chip sample across the dike, contains no significant values (table 11).

Near the head of the west fork of Coal Creek, another basalt dike, about 10 feet $(3.0 \mathrm{~m})$ thick, strikes N. $60^{\circ}$ E. in the San Juan Formation. An 8-foot (2.4-m) granodiorite porphyry dike striking N. $42^{\circ}$ E. cuts across the basalt dike. Sample 300 was taken across 2 feet $(0.6 \mathrm{~m})$ of brecciated material at the junction of the two dikes. Sample 299 was taken across 1 foot $(0.3 \mathrm{~m})$ of the middle part of the granodiorite dike approximately 10 feet $(3 \mathrm{~m})$ northeast of the junction. Analyses of the two samples showed no mineral values of interest.

\section{BEAVER CREEK}

An extremely altered dike crops out in the San Juan Formation near the head of Beaver Creek, about 11/4 miles $(2 \mathrm{~km})$ south of the western contiguous area boundary; the dike strikes $\mathrm{S} .15^{\circ} \mathrm{E}$. and is nearly vertical. Limonite-stained, minute fractures paralleling the dike are exposed in a small prospect pit. About 750 feet $(230 \mathrm{~m})$ upstream, a 12 -foot $(3.7-\mathrm{m})$ dike of altered hornblende-diorite porphyry strikes $\mathrm{S} .50^{\circ} \mathrm{E}$. and dips $78^{\circ} \mathrm{NE}$. Quartz-calcite stringers are dispersed throughout the middle 3 feet $(1 \mathrm{~m})$ of the dike. Chip samples 301 and 302 from the pit and dike contained no sig. nificant values.

\section{WILSON CREEK}

Wilson Creek drains the northeast side of Mount Sneffels. The Cowboy adit, at the foot of a cliff about 600 feet $(180 \mathrm{~m})$ north of the junction of the east and west forks of Wilson Creek (figs. 10,11; pl. 3B), was driven 287 feet $(88 \mathrm{~m})$ southeast along a 4 -foot $(1.2-\mathrm{m})$ fracture zone filled with quartz stringers. At the face of the adit the fracture zone strikes $\mathrm{S} .77^{\circ} \mathrm{E}$. and dips $73^{\circ} \mathrm{SW}$. At 28 feet $(8.5 \mathrm{~m})$ from the portal, a crosscut was driven southwest and some stoping was done. Sample 304, a chip sample across the fracture zone in the face of the adit, and sample 305 , a grab sample from a muck pile, showed no mineral values of interest. 


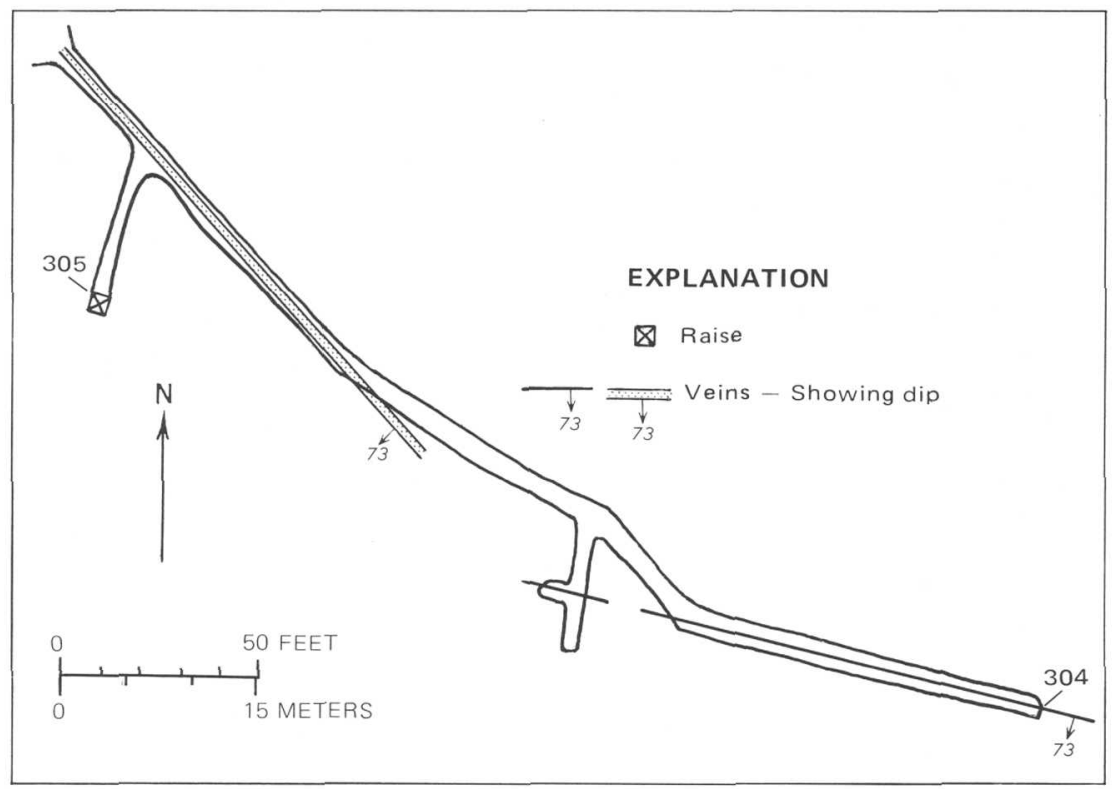

Figure 10.-Map of the Cowboy adit showing sample localities 304 and 305.

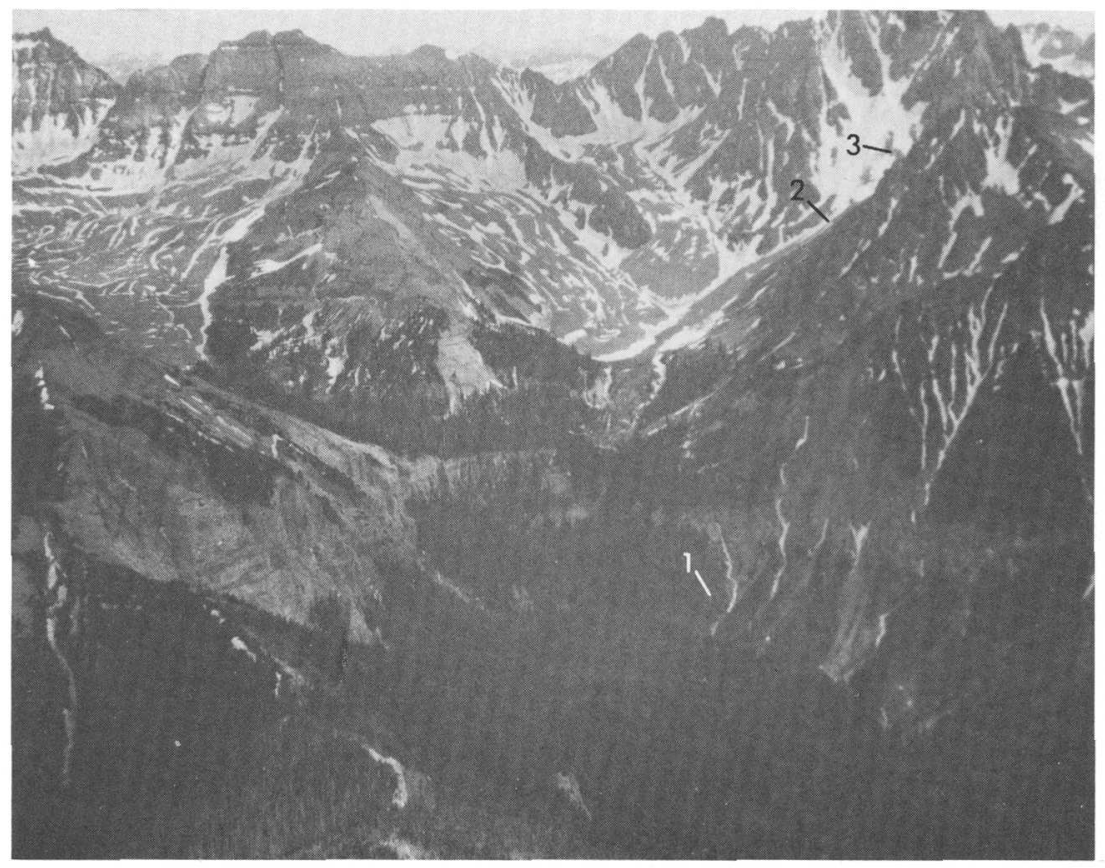

FIGURE 11.-Aerial view of Blaine Basin, looking southwest. (1) Cowboy adit, (2) Blaine mine, (3) locality for sample 311. 
Near the head of the east fork of Wilson Creek, a caved adit appears to have been driven south. Analytical results of sample 303, a grab from the dump, showed no anomalous metal.

The west fork of Wilson Creek drains Blaine Basin (fig. 11) where several openings were examined. The Blaine mine, the largest working, is actually one-half mile $(0.8 \mathrm{~km})$ northwest of the location shown on U.S. Geological Survey Mount Sneffels quadrangle topographic map. The adit of the Blaine mine (fig. 12) was driven southwest 1,264 feet $(380 \mathrm{~m})$ to intersect three steeply dipping north-south veins. Samples 306-309, taken in the adit, assayed small amounts of gold, silver, lead, and zinc.

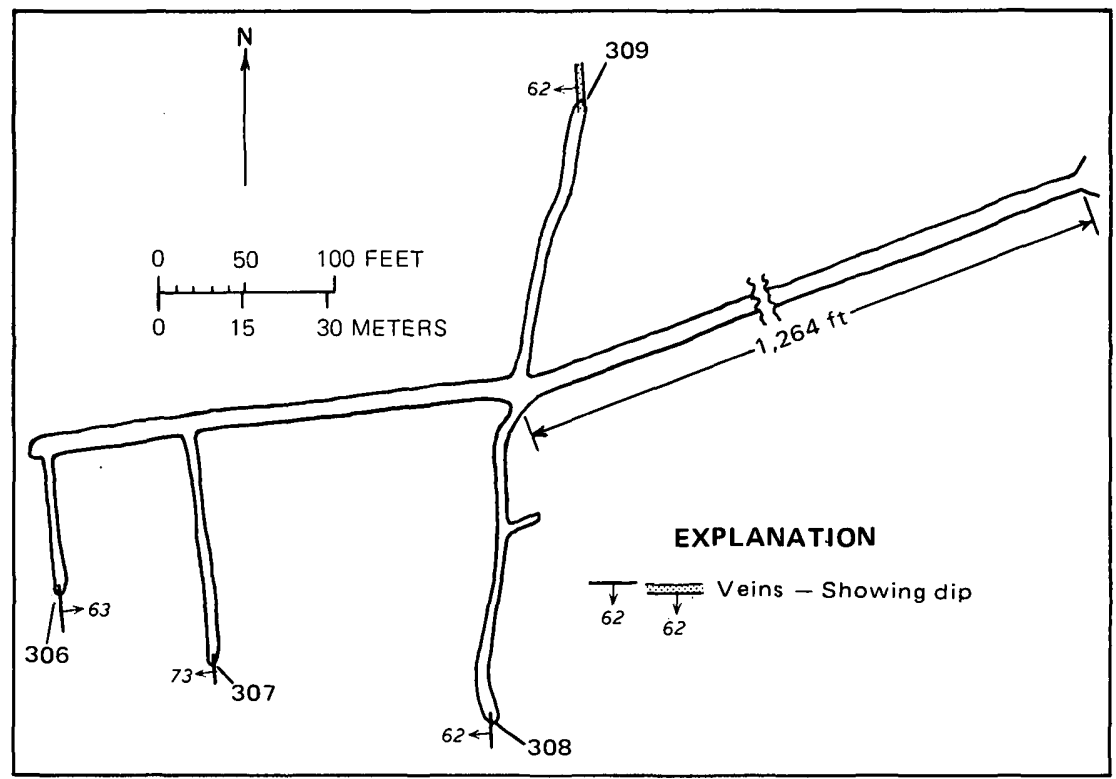

Figure 12.-Map of the Blaine mine showing sample localities 306-309.

About 300 feet $(90 \mathrm{~m})$ southwest of the Blaine portal, a fracture zone in granodiorite porphyry is exposed in a discovery pit; sample 310 , taken across the zone, showed no mineral values of interest.

Several other prospect pits were dug in granodiorite porphyry about one-half mile $(0.8 \mathrm{~km})$ southwest of the Blaine portal, on the divide between west fork of Wilson Creek and East Fork Dallas Creek. Sample 312 was taken across a 2.5 -foot $(0.8-\mathrm{m})$ vein in the face of a 27 -foot-long (8$\mathrm{m}$-long) adit; the sample assayed a trace of gold, 1.2 ounces of silver per ton, 0.48 percent lead, and 1.98 percent zinc. Sample 313, taken from a 1,200-ton (1,100-t) dump at the caved Mountain Monarch adit, assayed a trace of gold, 14.4 ounces of silver per ton, 0.04 percent copper, 0.77 percent lead, 0.80 percent zinc, and 0.04 percent antimony. Another caved 
adit, apparently driven $S .63^{\circ} \mathrm{W}$., is about 225 feet $(70 \mathrm{~m})$ southeast of the Mountain Monarch adit. The analysis of sample 311 (fig. 11) from the dump showed small amounts of silver, copper, lead, and zinc.

\section{BLUE LAKES}

Three prospect workings in granodiorite porphyry were examined in the Blue Lakes area west of Mount Sneffels. The first, a short adit 300 feet $(90 \mathrm{~m})$ below the lower Blue Lake, exposes a limonite-stained, quartzfilled fracture zone 4 feet $(1.2 \mathrm{~m})$ wide. Chip sample 314 taken at the face contains no significant values. The second excavation, about 50 feet $(46$ $\mathrm{m}$ ) east of the lower Blue Lake, is a 42 -foot $(13-\mathrm{m})$ adit driven $\mathrm{S} .78^{\circ} \mathrm{E}$. on a 3-foot (1-m) limonite-stained, quartz-filled fracture zone. Sample 315 taken across the face showed no mineral values of interest.

The third prospect, about 150 feet $(45 \mathrm{~m})$ northwest of the outlet of the upper Blue Lake, consists of a 15 -foot $(4.5 \mathrm{~m})$ adit driven along a 1 -foot (0.3-m) fracture zone, a 12-foot (3.7-m) shaft, and a 45-foot (14-m) drift that was driven S. $5^{\circ} \mathrm{E}$. from the bottom of the shaft. Chip sample 316 was taken across a 4 -foot $(1.2-\mathrm{m})$ width of manganese-stained, quartz-filled fracture zone exposed in the face of the drift. The sample yielded a trace of gold, 0.1 ounce of silver per ton, 0.24 percent lead, and 0.48 percent zinc (table 11).

\section{CENTRAL CONTIGUOUS AREA}

The central contiguous area is immediately north of the eastern part of the Uncompahgre Primitive Area. The area consists of about 25 square miles $\left(64 \mathrm{~km}^{2}\right)$ in Ouray County between the Uncompahgre River and Cow Creek.

The southwest side of the central contiguous area borders a highly mineralized area associated with a major intrusive center located just north of Ouray. Many productive veins and replacement bodies containing precious and base metals have been developed in the drainage basins of Dexter and Cutler Creeks, and numerous claims have been staked on the nearby slopes to the north, within the adjacent contiguous study area (pl. $3 A$ ). An excellent possibility exists that mineralized rock similar to that mined along Dexter Creek extends northeast beneath younger volcanic cover into the central contiguous area.

Other mineralized material in sedimentary rocks beneath the younger volcanic cover is exposed along Cow Creek on the east and northeast sides of the central contiguous area. The buried sedimentary rocks between the mineralized area on Cow Creek and the mineralized intrusive center near Ouray, thus, may contain significant hidden mineral resources.

A younger intrusive center cuts the volcanic rocks on Bighorn Ridge, west of upper Cow Creek and largely within the Uncompahgre Primitive Area. Samples from this center indicate that some potential exists for lowgrade disseminated copper mineralization. 


\section{COW CREEK}

Cow Creek is the eastern border of the central contiguous area. Numerous claims have been located along Cow Creek. In the Courthouse Creek area, three caved adits, one reportedly 1,100 feet ( $335 \mathrm{~m}$ ) long, appear to have been driven northeast in Dakota Sandstone. Analyses of samples 157-159 from the dumps revealed no mineral values of interest (table 11).

At the mouth of Winchester Gulch, about one-fourth mile $(0.4 \mathrm{~km})$ north of the New York mine area, numerous prospect pits and adits were examined. Most of the openings are on east-trending calcite-barite veins along fractures and fault zones in the Wanakah Formation. The largest working in the area is the Silver Queen adit, which is now caved. Sample 167, from a 600-ton (540-t) dump, assayed 0.3 ounce of silver per ton, 0.02 percent copper, and 0.31 percent lead.Approximately 450 feet $(137 \mathrm{~m})$ east of the Silver Queen dump and 75 feet $(23 \mathrm{~m})$ higher, near the contact between the Wanakah and Morrison Formations, the Hidden Silver adit (fig. 13) was driven southeast for over 200 feet $(60 \mathrm{~m})$ on the Silver Queen vein. Samples $160-166$ contain as much as 4.4 ounces of silver per ton, 0.01 percent copper, 0.32 percent lead, and 0.16 percent zinc which is present in a sample of a 15-ton (13.5-t) dump.

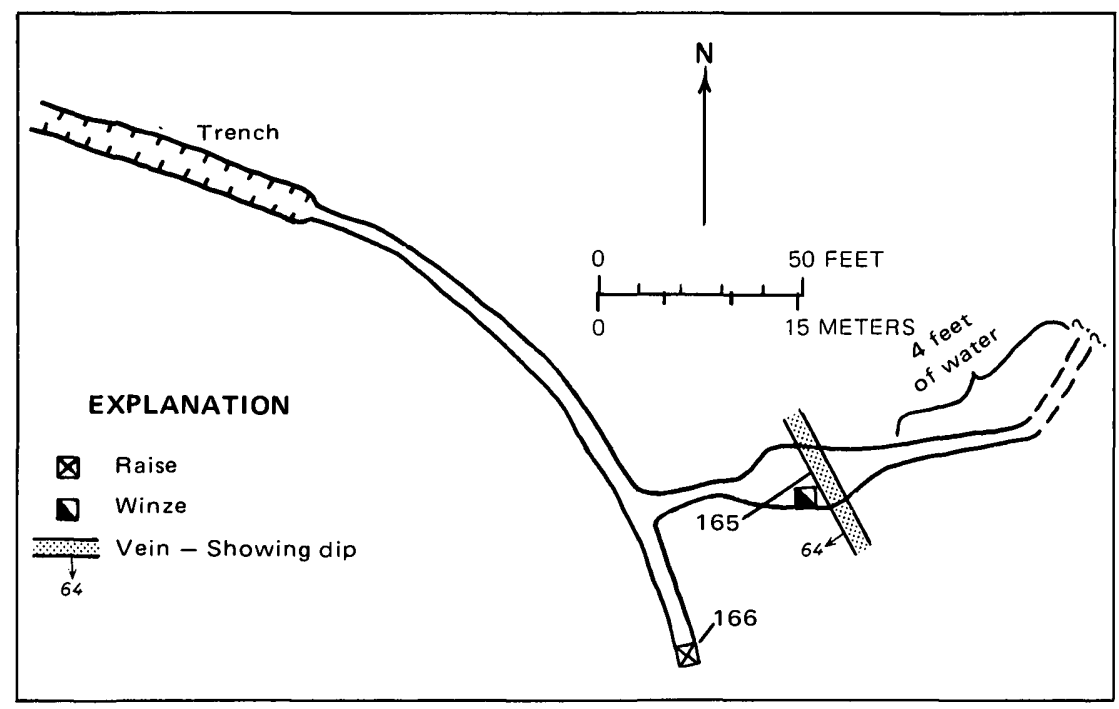

FIGURE 13.-Map of the Hidden Silver adit showing sample localities 165 and 166 .

The New York adit (fig. 14) was driven 450 feet $(137 \mathrm{~m})$ east in a manganese-stained fault zone about on the contact between the Cutler and Dolores Formations. Analyses of samples 168 and 169 revealed no metals of value. About one-fourth mile $(0.4 \mathrm{~km})$ south of the New York adit and 600 feet $(180 \mathrm{~m})$ west of Cow Creek, two adits were driven south 


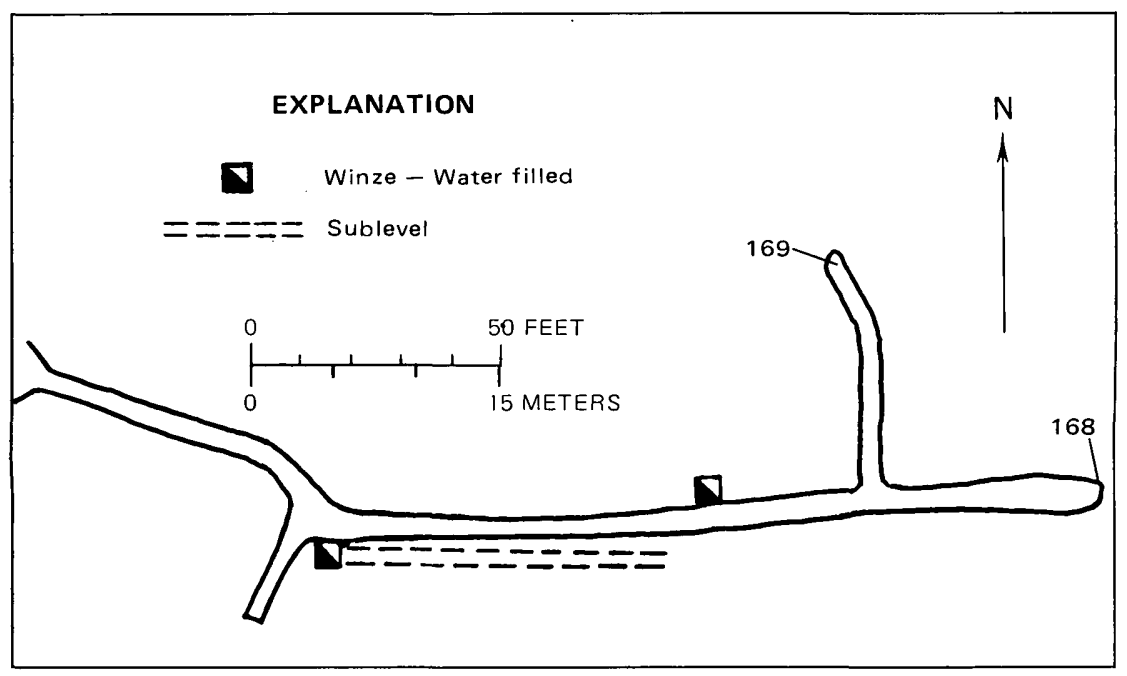

Figure 14.-Map of the New York adit showing sample localities 168 and 169.

along kaolinized fault zones in rhyolite. The lower of the two adits is 127 feet $(38 \mathrm{~m})$ long, and the higher is 167 feet $(50 \mathrm{~m})$ long. Samples 170 and 171 contained no mineral values of interest.

Two prospects-a short adit and a small pit-high up on the west side of Cow Creek and southwest of the New York mine were examined; spectrographic analyses of samples 173 and 174 indicated no values of interest.

The partially caved and water-filled Williams adit, near the head of Winchester Gulch, was reportedly driven 300 feet $(90 \mathrm{~m})$ southwest and several crosscuts were turned from the main drift. Samples 175-177 yielded no anomalous values.

On the north end of Bighorn Ridge (fig. 15), along the northern boundary of the original Uncompahgre Primitive Area, a quartz-latite porphyry intrusive center with associated andesitic and rhyolitic dikes (Foss, 1964) cuts the San Juan Formation. A small quartz monzonite plug within the center is strongly pyritized and kaolinized and the contacts are obscured by the alteration. Chip samples 178-183 were taken of the altered material; sample 182 contains $200 \mathrm{ppm}$ copper, and most assayed a trace of gold and from a trace to 0.2 ounce of silver per ton. Baumgartner Oil Co., Denver, Colo., staked a group of claims in the area and conducted geological mapping and geochemical sampling in 1971-72.

\section{DEXTER CREEK}

Dexter Creek is along the south boundary of the central contiguous area. Although only a very small segment of Dexter Creek is within the study area (pl. $3 A$ ), workings on the north side of the creek project toward 


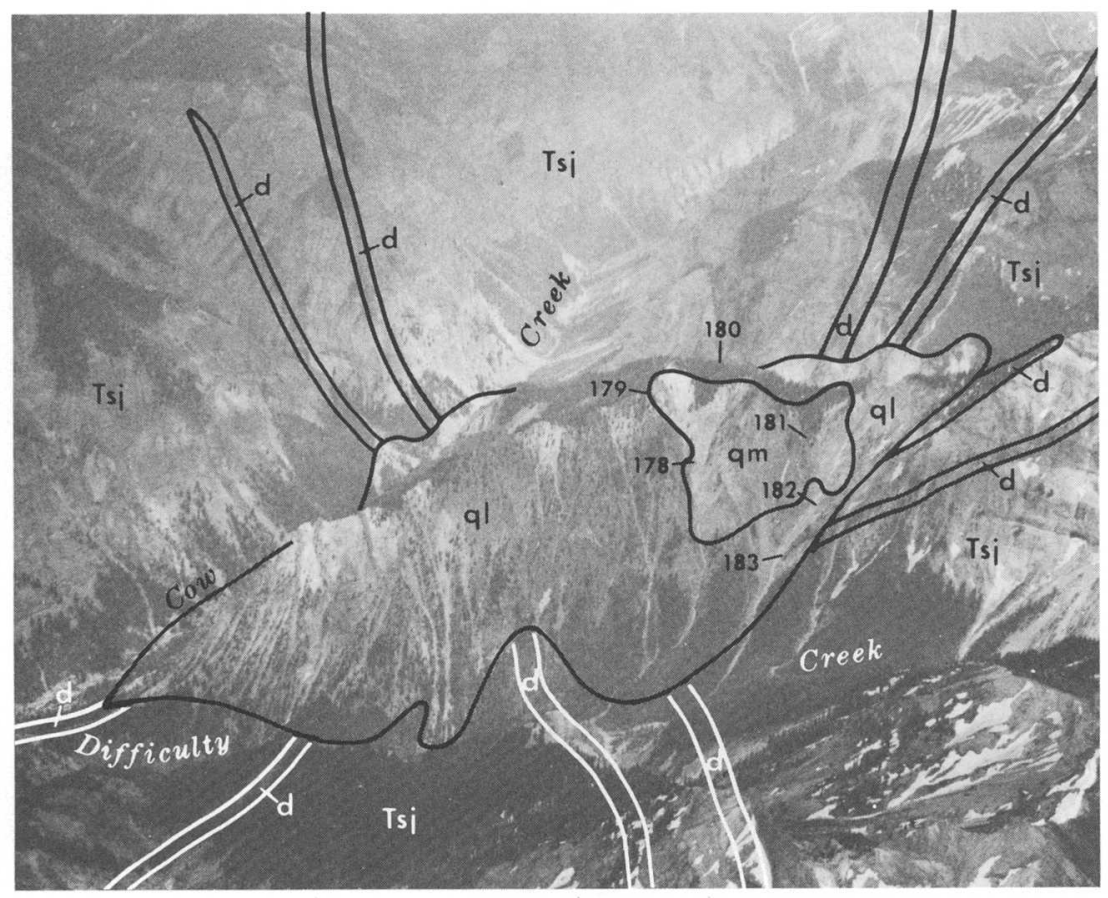

FIGURE 15.-Aerial view of the northern end of Bighorn Ridge, looking east, showing sample localities 178-183. Tsj, San Juan Formation; ql, quartz latite porphyry; d, andesitic and rhyolitic dikes; qm, quartz monzonite plug.

the contiguous area and some may extend into it. The Bachelor group of workings (fig. 16)-consisting of the Old Maid and El Mahdi (Almadi) shafts, the Bachelor and Khedive adits, and the Calliope group of openings-accounted for the recorded production from the Dexter Creek area.

Five prospects were examined in the upper reaches of Dexter Creek, and samples 184-188 were taken. Assay results show negligible amounts of metal. Numerous mine workings and prospects exist in the area from the Old Maid shaft (site of sample 189) west to a small prospect adit (site of sample 208). These include prospect pits, shafts as much as 300 feet $(90 \mathrm{~m})$ deep, and adits as long as 1,400 feet $(430 \mathrm{~m})$ dug mostly along north- to east-trending fractures in the Morrison Formation or the Dakota Sandstone that are filled with quartz, calcite, and barite. Most of the workings along or near the creek level are shafts sunk to develop ore bodies in the Pony Express Member of the Wanakah Formation. According to Burbank (1940), the ore bodies generally consist of manganese-stained barite with galena, sphalerite, chalcopyrite, tetrahedrite, proustite, and local argentite that form local shoots, or "rolls," along the veins. 


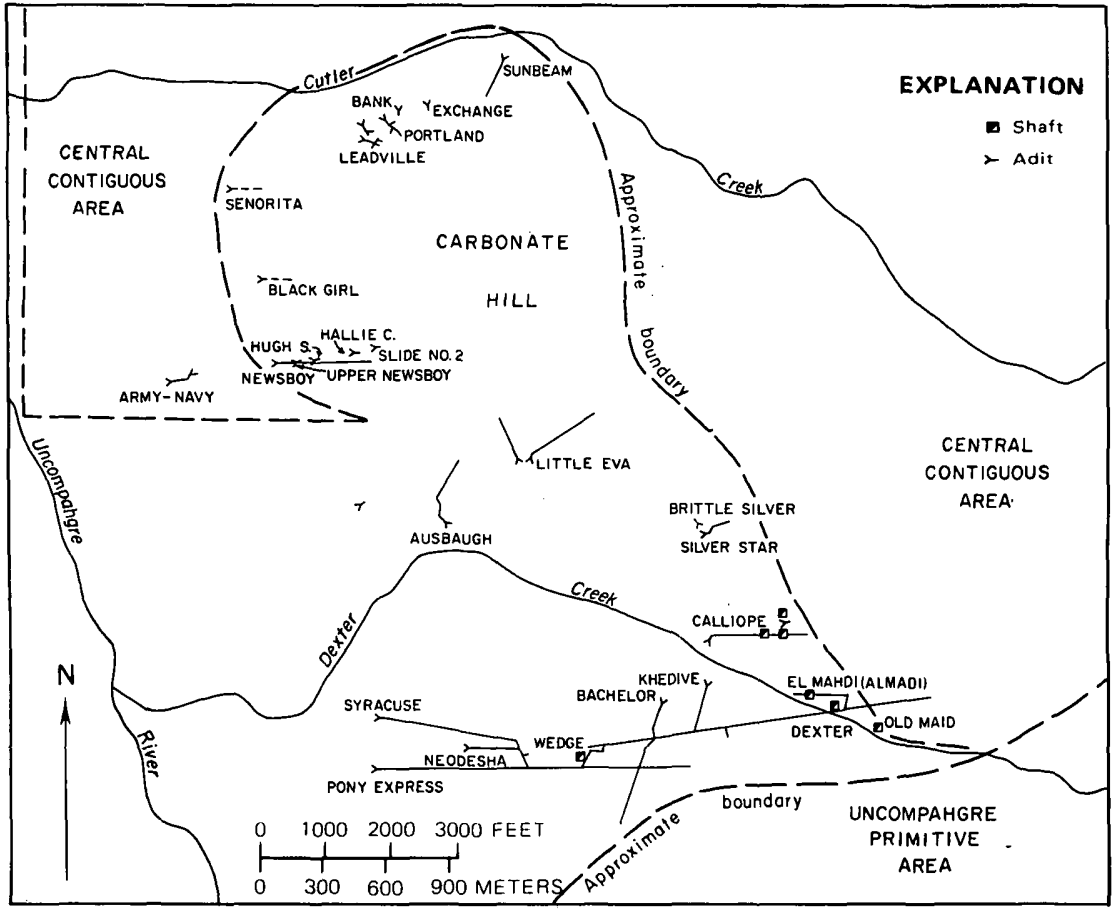

FIGURE 16.-Major underground mine workings of the Carbonate Hill area.

Samples 189-208, collected in the Dexter Creek area, all contained significant amounts of precious and base metals (table 11). The sample localities are as follows:

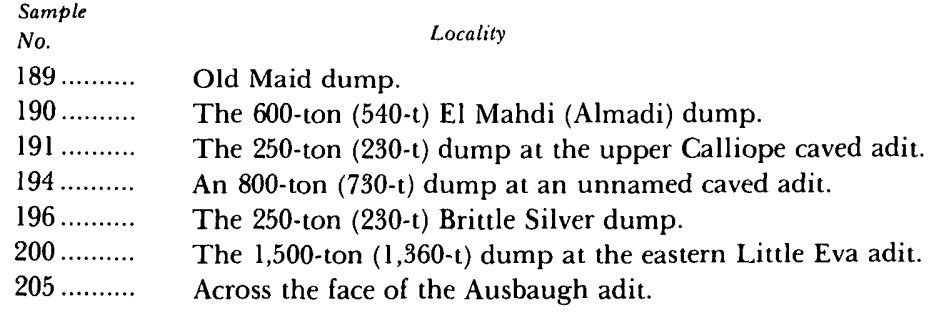

\section{CARBONATE HILL}

Carbonate Hill is between Dexter and Cutler Creeks. The major underground workings in and near Carbonate Hill are shown in figure 16. Sedimentary rocks exposed on the hill range from the Cutler Formation, at the base of the hill, to the Mancos Shale. These rocks are overlain by the volcanic San Juan Formation. Many adits were driven east into the west side of the hill. The main workings are the Newsboy, Army-Navy, Black Girl, and Senorita mines (fig. 17). Because access to the Black Girl and Senorita 


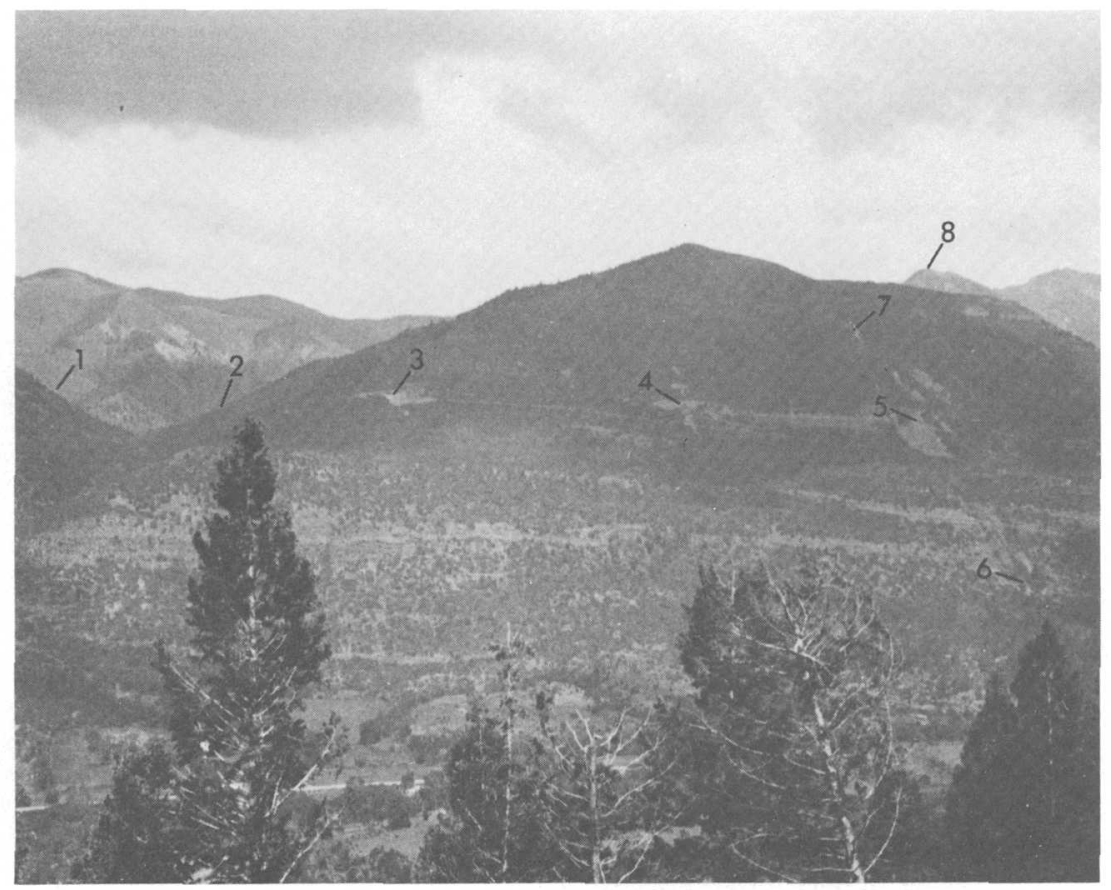

Figure 17.- View looking east toward Carbonate Hill from Little Gem mine area. (1) Storms Gulch, (2) Cutler Creek, (3) Senorita portal, (4) Black Girl portal, (5) lower Newsboy portal, (6) Army-Navy portal, (7) Slide No. 2 portal, (8) Dexter Peak.

mines was denied by the operators, only the Newsboy and Army-Navy mines were examined.

The Newsboy group of workings - consisting of the Newsboy mine and the upper Newsboy, Hugh S., Hallie C., and Slide No. 2 adits-is controlled by Depco, Inc., and Husky Oil Co., Denver, Colo. The Newsboy mine consists of two adits about 40 feet $(12 \mathrm{~m})$ apart. The north adit is 325 feet $(100 \mathrm{~m})$ long; the south adit is accessible for only 350 feet $(107 \mathrm{~m})$, but it is reported to be 2,200 feet $(670 \mathrm{~m})$ long. Sample 213 (table 11$)$, of the 600pound $(270-\mathrm{kg})$ stockpile by the south adit, and sample 214, taken across the 2.5 -foot $(0.76-\mathrm{m})$ vein at the face of the north adit, assayed significant amounts of silver and minor amounts of base metals. Official recorded production from the Newsboy mine is 1,985 tons of ore valued at $\$ 71,595$; however, company records show that considerably more ore was mined.

The Army-Navy adit (fig. 18) was driven along the Newsboy vein about 600 feet $(180 \mathrm{~m})$ below the Newsboy mine near the contact between the Entrada and Wanakah Formations. The vein is only about $1-1.5$ feet $(0.3-0.45 \mathrm{~m})$ wide at this mine. Sample 215 , taken across a 1.5 -foot $(0.45$ $\mathrm{m})$ vein at the face at the adit, assayed 0.3 ounce of silver per ton. The north 


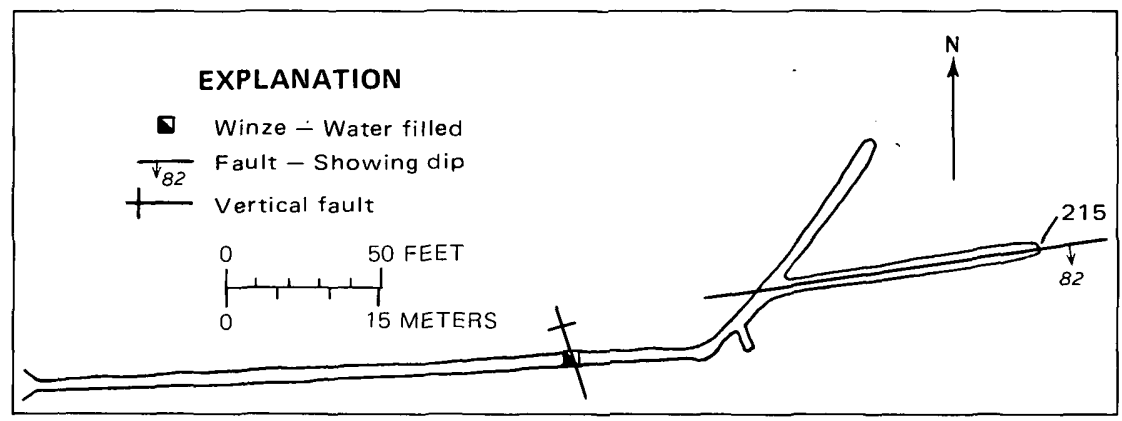

FIGURE 18.-Map of the Army-Navy adit showing sample locality 215.

crosscut from the Army-Navy was probably driven to intersect a cross vein from the Black Girl mine, but no vein was seen in the crosscut. Recorded production of the Army-Navy property is 5 tons of ore valued at $\$ 1,091$.

Samples 209-212 were grab samples taken from 500- to 3,000-pound (230- to 1,360-kg) stockpiles on the dumps at the caved adits of the Newsboy group of workings. Assay results are (table 11): trace to 0.2 ounce of gold per ton, 6.2 to 29.5 ounces of silver per ton, 0.45 to 8.28 percent lead, 0.13 to 6.36 percent zinc, and 0.02 to 0.08 percent antimony.

\section{CUTLER CREEK}

Numerous workings have been developed along Cutler Creek where the Wanakah Formation crops out. Openings on the south side of Cutler Creek were driven south to intersect the east-trending Senorita vein. An ore shoot along the vein in the Wanakah Formation is exposed in one of the Leadville adits and in the Bank, Portland, Exchange, and Sunbeam adits (fig. 16); the Sunbeam workings are shown in figure 19. On the north side of Cutler Creek, adits (fig. 20) as much as 200 feet $(60 \mathrm{~m})$ long were driven north on mineralized fractures in the Wanakah Formation. Most of the mineralized rock is in the black, limy shale of the Pony Express Member of the formation. Some adits were driven in the Morrison Formation and in the Dakota Sandstone. The only recorded production from the area is 312 tons $(283 \mathrm{t}$ ) of ore valued at $\$ 6,874$; this production was from the Portland mine, which is on the south side of Cutler Creek.

In the Cutler Creek area, samples 216-238, 240-243, 245 and 246 were taken from accessible adits and samples 239 and 244 are grab samples from dumps. Highest values were contained in samples 220 and 221 (table 11) from the Portland adit (fig. 21). Chip sample 220 across 2 feet $(0.6 \mathrm{~m})$ of black, siliceous limestone that strikes S. $65^{\circ} \mathrm{W}$. and dips $18^{\circ} \mathrm{SE}$. assayed 0.27 ounce of gold and 22.7 ounces of silver per ton, 0.30 percent copper, 1.32 percent lead, 0.44 percent zinc, 0.03 percent arsenic, and 0.21 percent antimony. Chip sample 221 from a 2 -foot $(0.6-\mathrm{m})$ vein that strikes $\mathrm{S} .5^{\circ} \mathrm{E}$. 


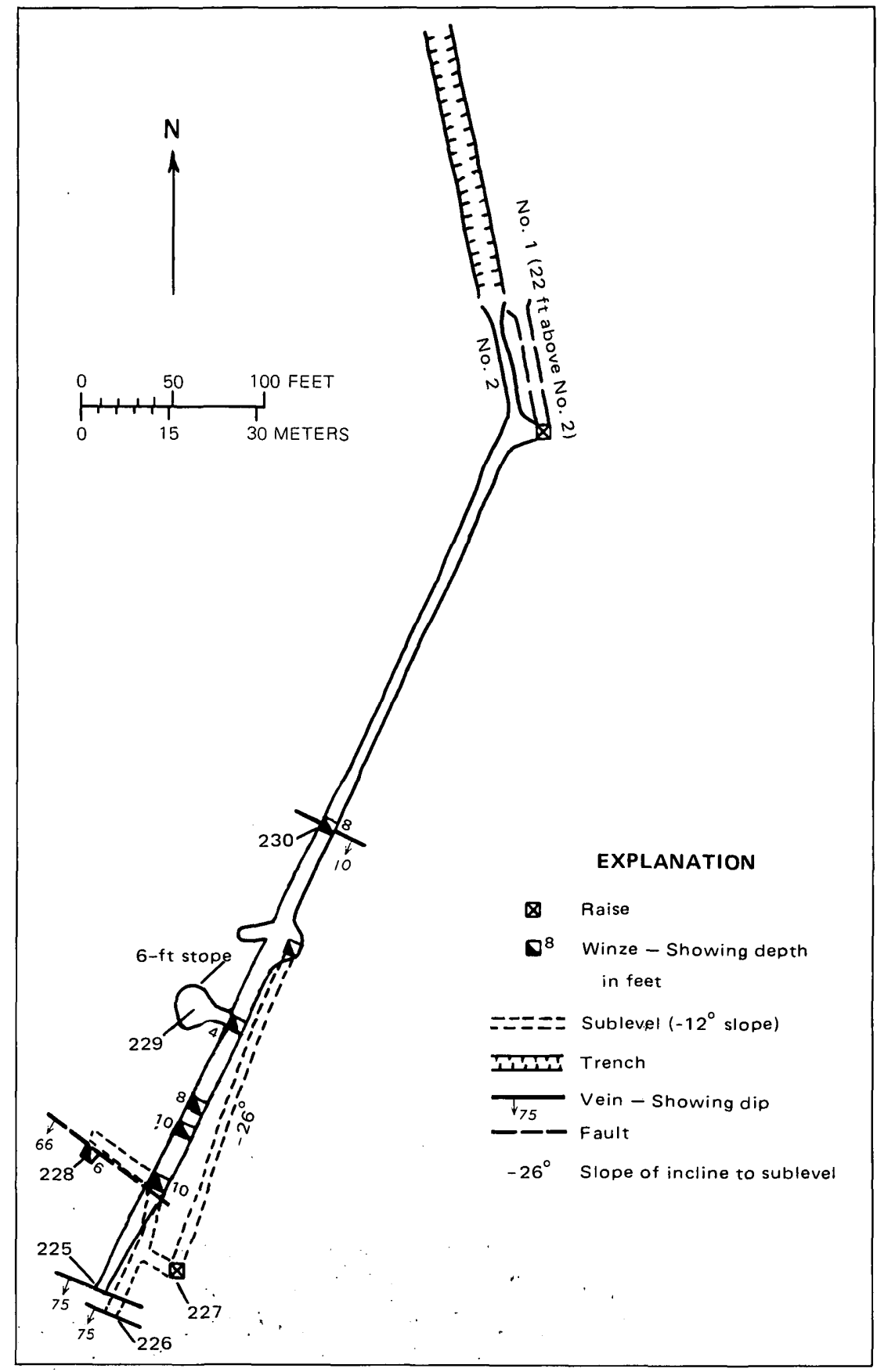

FIGURE 19.-Map of the Sunbeam workings showing sample localities 225-230. 


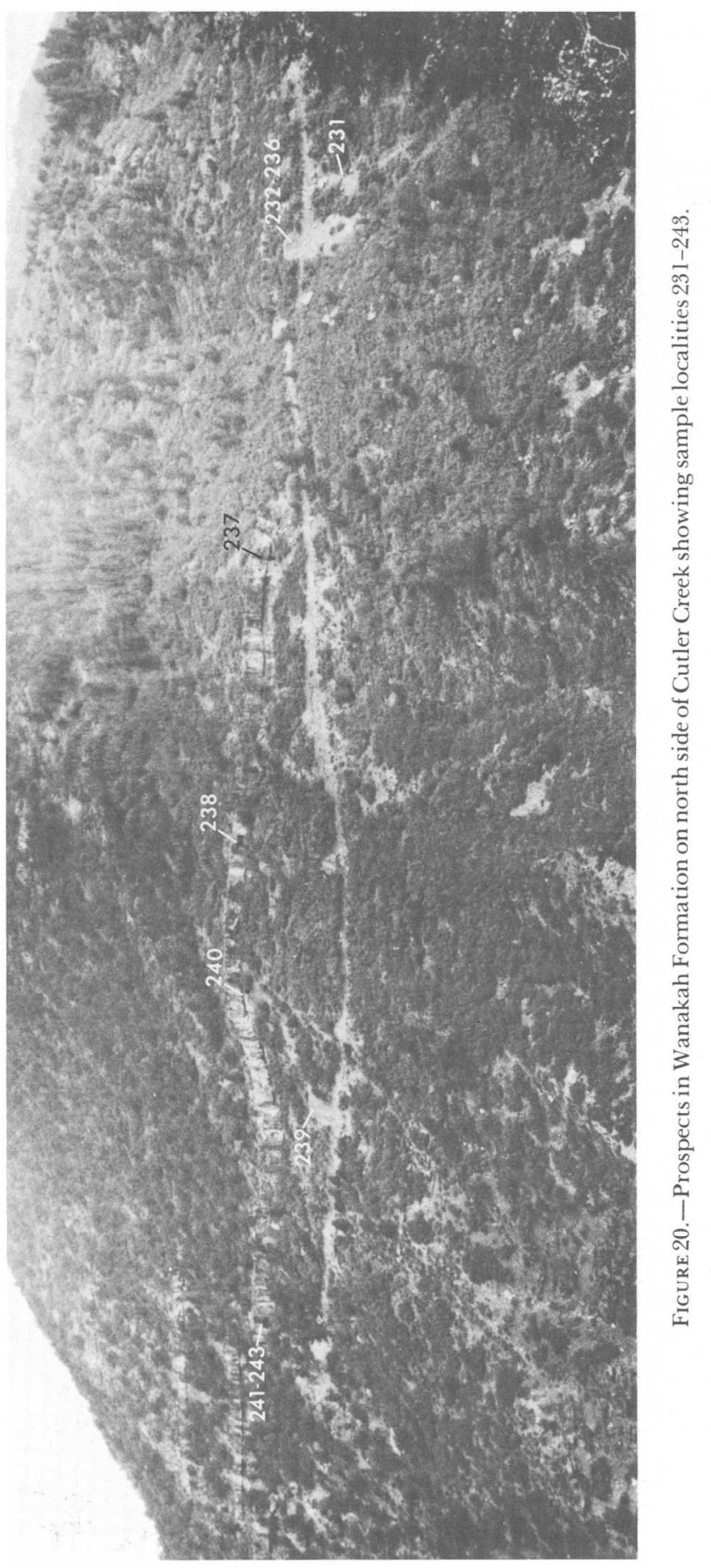




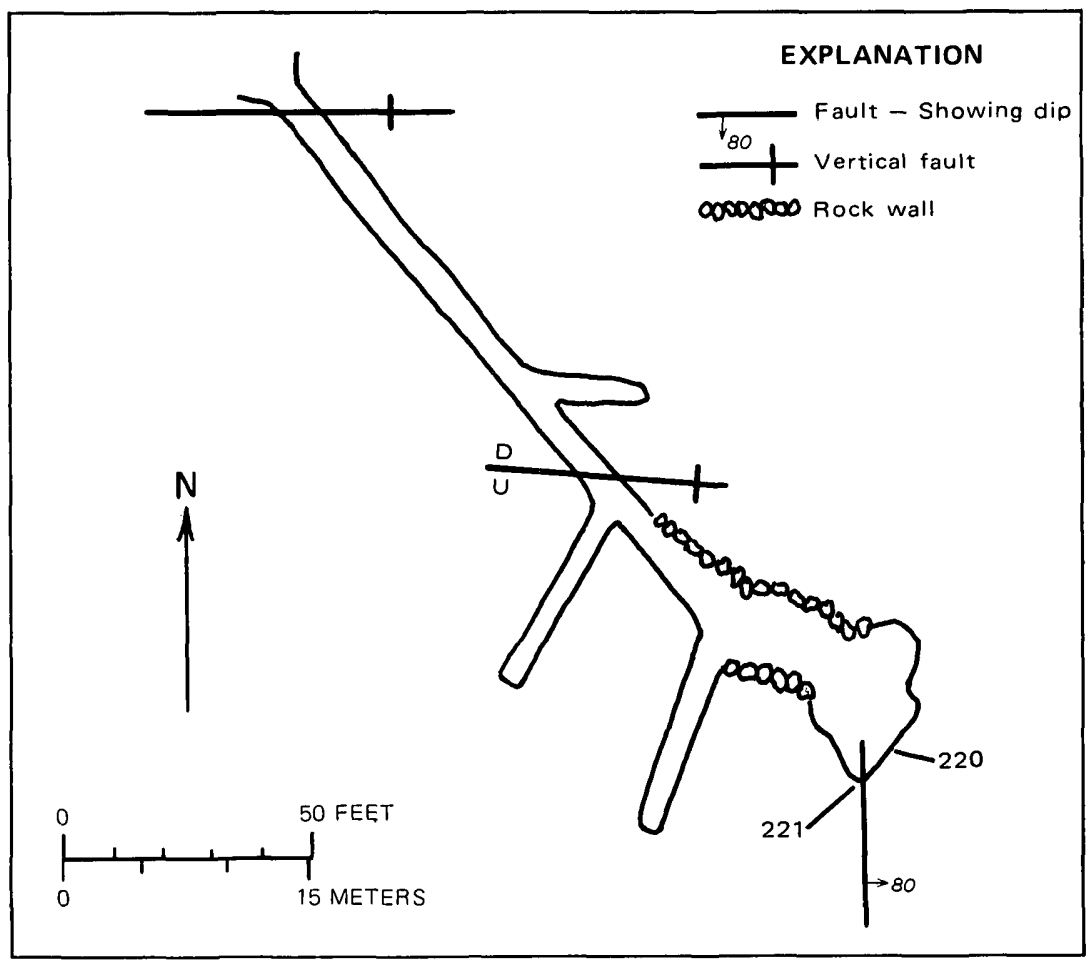

Figure 21.-Map of the Portland adit showing sample localities 220-221.

and dips $80^{\circ} \mathrm{E}$., assayed 0.12 ounce of gold and 10.8 ounces of silver per ton, 0.16 percent copper, 1.23 percent lead, 0.19 percent zinc, 0.04 percent arsenic, and 0.14 percent antimony. The other samples contain lesser amounts of these metals; samples 226 and 229 assayed 0.015 percent molybdenum.

\section{CROOKED TREE GULCH}

In Crooked Tree Gulch, two caved adits appear to have been driven north on fracture zones in the Dakota Sandstone. North of the gulch, two prospects adits were driven east on an andesite porphyry dike in the Cutler Formation. On the southwest slopes of Baldy Peak, a 35-foot (10.7-m) shaft was sunk on the intersection of two mineralized veins in the San Juan Formation. A small prospect pit is on a small, north-trending, kaolinized zone in the San Juan Formation. Samples 250-254, taken from dumps at these workings, assayed no values of interest.

\section{EASTERN CONTIGUOUS AREA}

The eastern contiguous area is east of the eastern part of the Uncompahgre Primitive Area and consists of more than 100 square miles (255 
$\mathrm{km}^{2}$ ) between the Middle Fork Cimarron River and the Lake Fork Gunnison River. Approximately two-thirds of the area is in Hinsdale County and the remaining part is in Gunnison County (pl. $3 A$ ). Numerous veins containing precious and base metals cut volcanic rocks on the lower slopes above Henson Creek, just south of the eastern contiguous area. Some potential exists for similar deposits in the immediately adjacent area to the north, within the southernmost part of the area studied.

Rhyolite intrusive bodies in the southern part of the eastern contiguous area are anomalously radioactive, and have been widely prospected for uranium. Surface samples of these bodies are generally low in grade, and large masses of rock containing appreciably more uranium would have to be found at depth before significant economic potential would be indicated.

Altered monzonitic intrusive centers were examined north of Matterhorn Peak and between the Silver Jack mine and Porphyry Basin. Anomalous metal contents, particularly of molybdenum, were detected at both of these centers, and some potential exists for low-grade disseminated molybdenum or copper deposits at depth.

\section{HENSON CREEK}

Old mines and prospects are in the area between Henson Creek and the southern boundary of the eastern contiguous area. The early history and geology of these mines and prospects were described by Irving and Bancroft (1911). The principal mines are the Ute-Ulay, Hidden Treasure, Pelican, and Yellow Medicine (fig. 22); these have supplied most of the gold, silver, copper, lead, and zinc mined in Hinsdale County. Galena, sphalerite, chalcopyrite, pyrite, and barite were identified in the dump rock of the mines. According to Irving and Bancroft (1911), the Ute-Ulay mine was among the largest sources of silver and lead in Colorado in the early days, when it was reported to have yielded $\$ 10-\$ 12$ million worth of metals. The U.S. Bureau of Mines records show that the mine was worked intermittently from 1911 to 1969 , producing about $\$ 600,000$ worth of gold, silver, copper, lead, and zinc.

The relationship of the underground workings of the Ute-Ulay, Hidden Treasure, and Pelican mines to the south boundary of the eastern contiguous area is shown in figure 22. Some of the northernmost workings of the Hidden Treasure and Pelican mines extend into the eastern contiguous area.

Old prospects pits, adits, and shafts are on the east side of Neoga Mountain 1 mile $(1.6 \mathrm{~km})$ west of Lake City (pl. $3 A$ ). The largest of these sampled is the Neoga shaft, which is about 40 feet $(12 \mathrm{~m})$ deep. Short drifts were driven north and south from the bottom of the shaft on a 3-foot (1-m) vein, which includes a veinlet of barite as much as 0.5 foot $(0.2 \mathrm{~m})$ wide. The vein strikes N. $30^{\circ}$ E. and is nearly vertical. Sample 33 , taken from this vein in the face of the north drift, assayed a trace of gold, 5.9 ounces of 


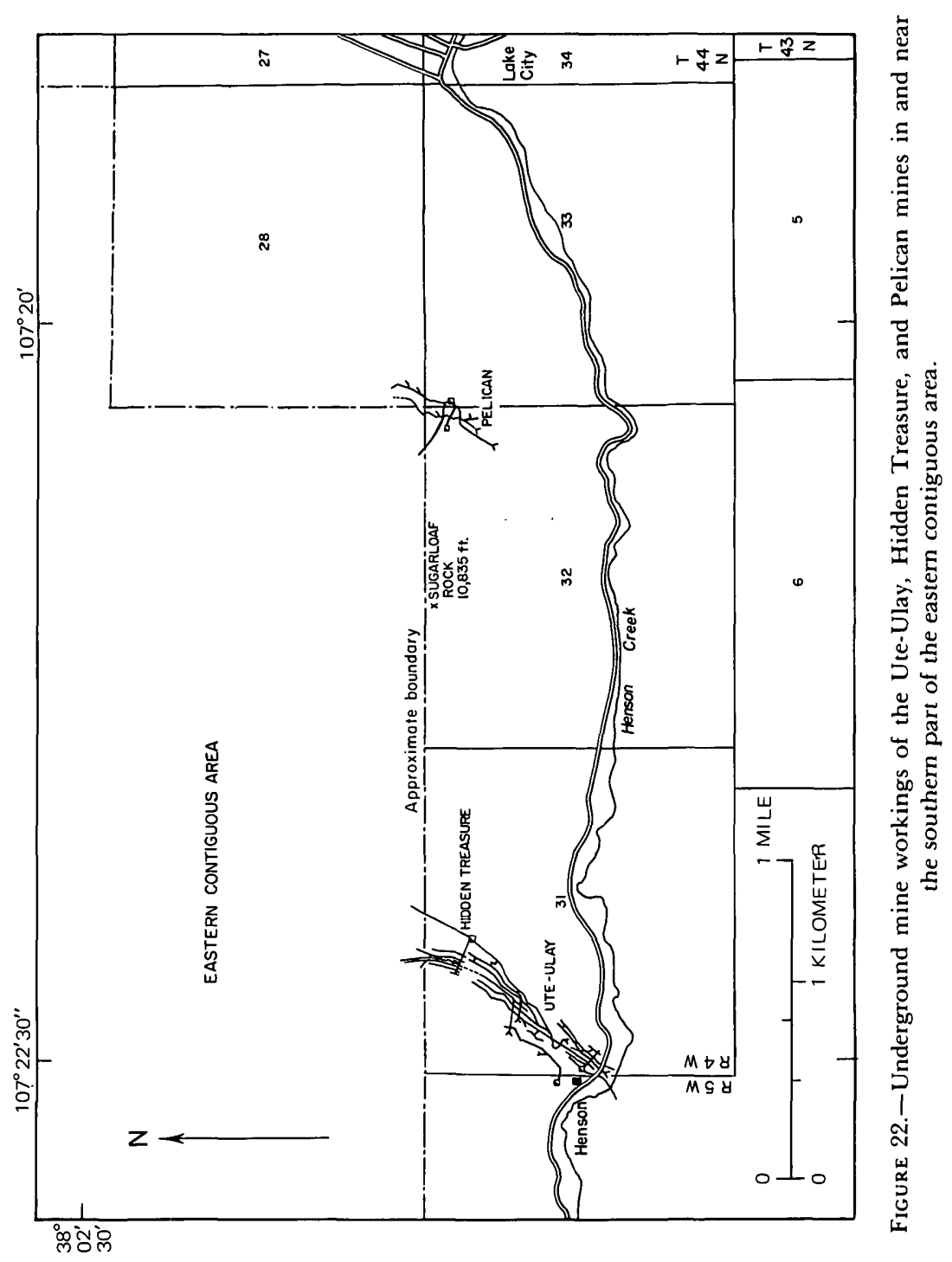


silver per ton, and small amounts of copper and lead (table 11). The vein is also exposed in a small pit 50 feet $(15 \mathrm{~m})$ southeast of the shaft. Sample 34 was taken across the barite veinlet, which is 0.25 foot $(0.1 \mathrm{~m})$ wide at this place, and sample 35 was taken across the rest of the vein, which is 2.5 feet $(0.7 \mathrm{~m})$ wide. The barite veinlet assayed a trace of gold and 8.8 ounces of silver per ton, whereas the whole vein assayed 6.7 ounces of silver per ton. Both samples contain only small amounts of copper and lead. Sample 36, taken across a 1.5-foot-wide (0.46-m-wide) gouge zone adjacent to the east side of the vein, assayed only 0.3 ounce of silver per ton and a very small amount of lead. A small pit and a trench about 150 feet $(46 \mathrm{~m})$ south of Neoga shaft were examined; sample 37, consisting of specimens from a 50 pound $(23-\mathrm{kg})$ stockpile by the trench, assayed a trace of gold, 62.1 ounces of silver per ton, 0.62 percent copper, 0.51 percent lead, and 0.68 percent antimony.

The Pelican mine is near the southeastern corner of the eastern contiguous area in sec. 32, T. 44 N., R. 4 W.; most of the workings are just outside the study area boundary (pl. 3A). Samples 47-50 (table 11), taken in the upper adit, assayed from a trace to 0.07 ounce of gold per ton, 2.7 to 14.3 ounces of silver per ton, $0.07-0.94$ percent lead, and $0.12-1.70$ percent zinc. Gold and silver values from sample 51 from the dump (700 tons, or $635 \mathrm{t}$ ) at the upper adit and sample 46 from the dump (400 tons, or $360 \mathrm{t}$ ) by the shaft above the upper adit fall within the above ranges.

Joker Gulch, east of the Pelican mine and 1 mile $(1.6 \mathrm{~km})$ north of Henson Creek, is the site of numerous old prospect workings. The two largest workings are the Joker adit and shaft. Sample 44 (table 11) of the dump (200 tons, or $180 \mathrm{t}$ ) by the Joker adit assayed a trace of gold and 0.5 ounce of silver per ton; sample 45 of the dump ( 250 tons, or $230 \mathrm{t}$ ) by the Joker shaft assayed a trace of gold and 1.0 ounce of silver per ton. Sample 43 of a dump (30 tons, or $27 \mathrm{t}$ ) by a caved adit north of the Joker shaft assayed 2.4 ounce of silver per ton. Sample 42, specimens from a 1-ton (0.9-t) stockpile by a small trench north of the Joker adit, assayed 0.01 ounce of gold and 7.4 ounces of silver per ton.

The Ute-Ulay mine is about 3 miles $(4.8 \mathrm{~km})$ west of Lake City and is about one-half mile $(0.8 \mathrm{~km})$ south of the study area boundary. It was possible to examine only the No. 5 level of the workings. Sample 52 (table $11)$, taken across the 3.75 -foot $(1.1-\mathrm{m})$ vein in the face at the end of the 4,000-foot (1,220-m) drift, assayed a trace of gold and 2.3 ounces of silver per ton. Sample 53, a grab sample from a muck pile on the floor near the face, assayed 5.4 ounces of silver per ton. Both samples contain some copper, lead, and zinc.

The Hidden Treasure mine lies northeast of the Ute-Ulay workings. The workings, which are inaccessible, are mostly south of the eastern contiguous area, but some extend into it. 
The workings of the Vermont mine on El Paso Creek, which are also inaccessible, are 1 mile south of the study area boundary. Sample 101, a grab from altered and mineralized rock in the dump $(4,000$ tons, or 3,600 t), assayed 0.02 ounce of gold and 9.8 ounces of silver per ton, 0.41 percent copper, 4.15 percent lead, and 2.22 percent zinc. Chip sample 102 across a 7 -foot $(2.1-\mathrm{m})$ vein cropping out along the south side of the dump assayed a trace of gold and 1.4 ounces of silver per ton, 0.99 percent lead, and small amounts of copper and zinc.

North of Capitol City, sample 103 was taken at the Czarina shaft, samples 104-108 at the Czar mine, and sample 109 in an adit near the Yellow Medicine mine. The workings lie approximately 1 mile $(1.6 \mathrm{~km})$ south of the study area boundary. Sample 106, taken across a 2-foot (0.6$\mathrm{m})$ vein in a stope 35 feet $(11 \mathrm{~m})$ from the portal of the upper adit of the Czar mine, assayed 0.05 ounce of gold and 11.6 ounces of silver per ton, 1.74 percent copper, 19 percent lead, and 4.56 percent zinc. The other samples assayed from a trace to 0.02 ounce of gold per ton, 1.4 to 5.9 ounces of silver per ton, 0.13 to 1.01 percent copper, 1.48 to 5.32 percent lead, and 0.32 to 3.74 percent zinc. In the summer of 1972, Joe Gomez of Crested Butte, Colo., was doing development work at the Yellow Medicine mine (site of sample 109) and was constructing a 25-ton-per-day mill nearby.

\section{UNCOMPAHGRE PEAK-NELLIE CREEK-LARSON CREEK}

The Uncompahgre Peak-Nellie Creek-Larson Creek area is in the southern part of the eastern contiguous area $(\mathrm{pl} .3 A)$. Rhyolite intrusives exposed between Uncompahgre Peak and Larson Creek have been of interest to uranium prospectors since the late 1950's. Numerous claims have been staked in this area, but very few prospect workings were found during our investigation. The only known uranium production is a small quantity (less than 100 tons, or $90 \mathrm{t}$ ) of ore mined about 1960 from the Beth claims (site of sample 117) located on the south slope of Uncompahgre Peak.

In 1969, Greater West Mining Co. drilled four diamond-drill holes on claims at the head of the east branch of Nellie Creek. Drilling results are not known; after the exploration, the company abandoned the project. In 1971 and 1972, Exxon Corp. conducted an exploration program consisting of geologic mapping, geochemical sampling, and diamond drilling near Nellie Creek and Matterhorn Peak.

Most samples collected in the Nellie Creek area were only weakly radioactive and did not register more than three times background count when checked with a Geiger counter. Radiometric analysis of certain selected samples gave the following results: 


\begin{tabular}{|c|c|c|c|}
\hline Sample & $\begin{array}{c}\mathrm{U}_{9} \mathrm{O}_{8} \\
\text { (percent) }\end{array}$ & Sample & $\begin{array}{c}\mathrm{U}_{3} \mathrm{O}_{8} \\
\text { (percent) }\end{array}$ \\
\hline $59 \ldots \ldots \ldots \ldots$ & 0.01 & $83 \ldots \ldots \ldots \ldots . . . .$. & 0.01 \\
\hline $61 \ldots \ldots \ldots \ldots$ & .10 & $110 \ldots \ldots \ldots \ldots$ & .01 \\
\hline $77 \ldots \ldots \ldots$ & .01 & $115 \ldots \ldots \ldots \ldots \ldots$ & .10 \\
\hline $79 \ldots \ldots \ldots \ldots$ & .01 & $117 \ldots \ldots \ldots \ldots$ & .07 \\
\hline $80 \ldots \ldots \ldots \ldots . . . .$. & .01 & $136 \ldots \ldots \ldots \ldots$ & .01 \\
\hline
\end{tabular}

Only samples 61,115 , and 117 contained significant quantities of uranium. Sample 61 was a 1 -foot $(0.3-\mathrm{m})$ chip of rhyolite in the wall of one of the trenches at the head of the east fork of Nellie Creek; this sample was from near the site of one of four holes drilled by the Greater West Mining Co. Sample 117 was a grab sample of rhyolite fragments at the portal of the caved adit on the Beth claims which are on the border of the primitive area. Sample 115 was taken near the discovery pit of the Ace claim in the primitive area; the sample consisted of a single selected specimen (a cube slightly more than an inch $(3 \mathrm{~cm})$ on a side) of rhyolite with visible uranophane. Sample 114, taken at the same spot, was a selected specimen of rhyolite without any visible uranophane; it registered only about twice background on the Geiger counter.

On the El Chaddai Ithiel group of claims, about 1 mile $(1.6 \mathrm{~km})$ north of the Larson Lakes, six trenches 50-100 feet (15-30 m) long and 2-6 feet (0.6-1.8 m) deep were dug with a bulldozer. The work was done in 1959 or 1960 by Eric Benson, one of the locators. The trenches are in rhyolite containing some stringers of iron and manganese oxides. Sample 68 , taken horizontally across 10 feet $(3 \mathrm{~m})$ of a wall at one of the trenches, contained 31.9 percent manganese and 0.06 percent molybdenum; the spectrographic analysis showed only small amounts of copper, cobalt, nickel, tin, and vanadium (table 11). A 60 -foot-wide (18-m-wide) zone of vitrophyre is exposed on the trail about 600 feet $(180 \mathrm{~m})$ northwest of the trenches. Sample 67 of this material contained no mineral values of interest.

The Treasure Hill Spar claim, about 1 mile $(1.6 \mathrm{~km})$ north of Henson Creek and one-fourth mile $(0.4 \mathrm{~km})$ east of Nellie Creek, was patented in 1883. In the center of the claim, a trench (designated as an opencut on the mineral survey plot) 160 feet $(50 \mathrm{~m})$ long, 8 feet $(2.4 \mathrm{~m})$ wide, and $1-2$ feet (0.3-0.6 m) deep exposes four 1.5 - to 6 -foot $(0.46$ - to $1.8-\mathrm{m})$ calcite veins. Assay results of samples 90-96, taken from the veins and float in the floor of the trench, indicated no mineral values of interest. Grab sample 99 was taken from a small pile of calcite that is near the remains of two log cabins on Nellie Creek; the material probably came from the trench on the patented claim. The sample contains only a trace of gold. 
Two other prospect pits near the Treasure Hill Spar claim were sampled. Grab sample 97 of a dump at the pit south of the claim contained no mineral values of interest. At the pit west of the claim, sample 98 was taken across a 1.8 -foot $(0.55-\mathrm{m})$ vein exposed in the pit; assays indicate 0.9 ounce of silver per ton, 0.2 percent copper, 0.04 percent lead, and 0.07 percent antimony.

\section{MATTERHORN PEAK}

An altered monzonite intrusive on the north side of Matterhorn Peak, at the head of the East Fork Cimarron River (pl. $3 A$ ), is surrounded by a halo of altered andesite. About 240 unpatented claims, consisting of the Cimarron Chief group ( 50 claims) and the Dix group (190 claims), have been located in the area. These claims have been explored for molybdenum; the latest work, in 1971, consisted of trenching and geochemical sampling by Dixilyn Corp. which had located the Dix claims and had leased the Cimarron Chief claims.

Samples 121-124, taken from bulldozed trenches in the alteration zone, showed only small amounts of molybdenum. The largest amount, 60 ppm molybdenum, was reported for sample 121; the other samples show less than $20 \mathrm{ppm}$ molybdenum (table 11 ). These traces of molybdenum possibly indicate that higher grade material may be at depth.

\section{SILVER JACK MINE AREA}

The Silver Jack mine area is on the East Fork Cimarron River, about 3 miles $(4.8 \mathrm{~km})$ north of Uncompahgre Peak. Six patented lode claims, one patented placer claim, and several unpatented claims are in the area. The Silver Jack mine is on Silver Creek, about one-fourth mile $(0.4 \mathrm{~km})$ from its mouth. Two adits, one on each side of the creek, probably were driven to investigate the nearby outcropping dikes; both adits are caved. Samples 136 and 141-143 (table 11) were taken from the dumps; assay results indicated no mineral values of interest. Sample 138, from a dump at a small pit on the north bank of Silver Creek below the two adits, assayed 0.09 ounce of gold and 0.2 ounce of silver per ton.

Samples 131 and 132, panned concentrates of sand and gravel, and samples 133 and 134, chip samples of dikes, were taken along the East Fork Cimarron River; analyses of samples showed no mineral concentrations of significance.

Samples 144-147 were chip samples taken across dikes exposed on the west side of the East Fork Cimarron River. The spectrographic analyses of these samples showed small amounts of copper (40-100 ppm), lead (100 and $400 \mathrm{ppm})$, and molybdenum (30 ppm); both samples 144 and 147 assayed 0.1 ounce of silver per ton.

Sample 149 was a panned concentrate of sand and gravel from the East Fork Cimarron River on the Pay Day patented placer claim. The analyses of this sample showed no mineral concentration of significant value. 
PORPHYRY BASIN

Porphyry Basin lies west of the Silver Jack mine area and is between the East and Middle Forks Cimarron River. At the time of the field investigation, one of the claim owners was doing assessment work. At the junction of the two forks that drain the basin, a 35 -foot $(11-\mathrm{m})$ adit was being driven due east in the hope of intersecting a gold vein reported to have been mined in the north-trending streambed about 1910. Samples 153 and 154, taken at the face of the adit, contained no mineral values of interest. Sample 155 , taken from a 0.5 -foot $(0.2-\mathrm{m})$ gouge zone in the streambed about 300 feet $(90 \mathrm{~m})$ east of the adit, assayed a trace of gold. Sample 150 from across a 0.5 -foot $(0.2-\mathrm{m})$ vein near a caved adit on the south bank farther upstream and sample 151 from a similar vein on the north bank each assayed a trace of gold. Sample 152, a grab sample from a dump near a caved shaft on the south bank of the northern streambed, assayed a trace of gold and 0.1 ounce of silver per ton. The analysis of sample 156, a sediment sample taken from the Porphyry Basin stream about one-quarter of a mile $(0.4 \mathrm{~km})$ above the Middle Fork Cimarron River, indicated traces of gold and silver.

\section{REFERENCES CITED}

Burbank, W. S., 1930, Revision of geologic structure and stratigraphy in the Ouray district of Colorado, and its bearing on ore deposition: Colorado Sci. Soc. Proc., v. 12 , no. 6 , p. 151-232.

1940, Structural control of ore deposition in the Uncompahgre district, Ouray, County, Colorado: U.S. Geol. Survey Bull. 906-E, p. 189-265.

1941, Structural control of ore deposition in the Red Mountains, Sneffels, and Telluride districts of the San Juan Mountains, Colorado: Colorado Sci. Soc. Proc., v. 14, no. 5, p. 141-261.

1947, Early Tertiary ore deposits, Uncompahgre (Ouray) district, Ouray County, in Vanderwilt, J. W., ed., Mineral resources of Colorado: Colorado Mineral Resources Board, p. 409-414.

Burbank, W. S., and Luedke, R. G., 1964, Geology of the Ironton quadrangle, Colorado: U.S. Geol. Survey Geol. Quad. Map GQ-291.

1966, Geology of the Telluride quadrangle, Colorado: U.S. Geol. Survey Geol. Quad. Map GQ-504.

1968, Geology and ore deposits of the western San Juan Mountains, Colorado, in Ore deposits of the United States, 1933-1967 (Graton-Sales Volume): Am. Inst. Mining, Metall. Engineers, p. 714-733.

1969, Geology and ore deposits of the Eureka and adjoining districts, San Juan Mountains, Colorado: U.S. Geol. Survey Prof. Paper 535, 73 p.

Bush, A. L., Bromfield, C. S., Marsh, O. T., and Taylor, R. B., 1961, Preliminary geologic map of the Gray Head quadrangle, San Miguel County, Colorado: U.S. Geol. Survey Mineral Inv. Field Studies Map MF-176.

Christiansen, R. L., and Lipman, P. W., 1972, Cenozoic volcanism and plate-tectonic evolution of the Western United States; II, Late Cenozoic: Royal Soc. London Philos. Trans., v. 271, p. 249-284.

Clark, K. F., 1972, Stockwork molybdenum deposits in the western cordillera of North America: Econ. Geology, v. 67, no. 6, p. 731-758. 
Cross, Whitman, and Larsen, E. S., Jr., 1935, A brief review of the geology of the San Juan region of southwestern Colorado: U.S. Geol. Survey Bull. 843, 138 p.

Cross, Whitman, and Purington, C. W., 1899, Description of the Telluride quadrangle, Colorado: U.S. Geol. Survey Geol. Atlas, Folio 57, 18 p.

Cross, Whitman, Howe, Ernest, and Ransome, F. L., 1905, Description of the Silverton quadrangle, Colorado: U.S. Geol. Survey Geol. Atlas, Folio 120, 34 p.

Cross, Whitman, Howe, Ernest, and Irving, J. D., 1907, Description of the Ouray quadrangle, Colorado: U.S. Geol. Survey Geol. Atlas, Folio 153.

Dickinson, R. G., Leopold, E. B., and Marvin, R. F., 1968, Late Cretaceous uplift and volcanism on the north flank of the San Juan Mountains, Colorado, in Epis, R. C., ed., Cenozoic volcanism in the southern Rocky Mountains: Colorado School Mines Quart., v. 63, no. 3, p. 125-148.

Fischer, R. P., Luedke, R. G., Sheridan, M. J., and Raabe, R. G., 1968, Mineral resources of the Uncompahgre Primitive Area, Colorado: U.S. Geol. Survey Bull. 1261-C, $91 \mathrm{p}$.

Foss, T. H., 1964, Chemical and mineralogic variations in the radial dikes of the Difficulty Creek intrusive center, San Juan Mountains, Colorado: Houston, Tex., Rice Univ. Ph. D. thesis, $72 \mathrm{p}$.

Godwin, L. H., Haigler, L. B., Rioux, R. L., White, D. E., Muffler, L. J. P., and Wayland, R. G., 1971, Classification of public lands valuable for geothermal steam and associated geothermal resources: U.S. Geol. Survey Circ. 647, 18 p.

Haffty, Joseph, and Noble, D. C., 1972, Release and migration of molybdenum during the primary crystallization of peralkaline silicic volcanic rocks: Econ. Geology, v. 67 , no. 6, p. 768-775.

Irving, J. D., and Bancroft, Howland, 1911, Geology and ore deposits near Lake City, Colorado: U.S. Geol. Survey Bull. 478, 128 p.

Kelley, V. C., 1946, Geology, ore deposits, and mines of the Mineral Point, Poughkeepsie, and Upper Uncompahgre districts, Ouray, San Juan, and Hinsdale Counties, Colorado: Colorado Sci. Soc. Proc., v. 14, no. 7, p. 287-466.

King, W. H., and Allsman, P. T., 1950, Reconnaissance of metal mining in the San Juan region, Ouray, San Juan, and San Miguel Counties, Colorado: U.S. Bur. Mines Inf. Circ. 7554, 109 p.

Landis, E. R., 1959, Coal resources of Colorado: U.S. Geol. Survey Bull. 1072-C, p. 131-232.

Larsen, E. S., Jr., 1911, The economic geology of Carson Camp, Hinsdale County, Colorado: U.S. Geol. Survey Bull. 470-B, p. 30-38.

Larsen, E. S., Jr., and Cross, Whitman, 1956, Geology and petrology of the San Juan region, southwestern Colorado: U.S. Geol. Survey Prof. Paper 258, 303 p.

Lindsley, D. H., Andreasen, G. E., and Balsley, J. R., 1966, Magnetic properties of rocks and minerals, in Clark, S. P., Jr., ed., Handbook of physical constants [revised ed.]: Geol. Soc. America Mem. 97, p. 543-552.

Lipman, P. W., Christiansen, R. L., and Van Alstine, R. E., 1969, Retention of alkalis by calc-alkalic rhyolites during crystallization and hydration: Am. Mineralogist, v. 54, nos. 1-2, p. 286-291.

Lipman, P. W., Steven, T. A., and Mehnert, H. H., 1970, Volcanic history of the San Juan Mountains, Colorado, as indicated by potassium-argon dating: Geol. Soc. America Bull., v. 81, no. 8, p. 2329-2352.

Lipman, P. W., Steven, T. A., Luedke, R. G., and Burbank, W. S., 1973, Revised volcanic history of the San Juan, Uncompahgre, Silverton, and Lake City calderas in the western San Juan Mountains, Colorado: U.S. Geol. Survey Jour. Research, v. 1, no. 6 , p. $627-642$.

Luedke, R. G., 1972, Geology of the Wetterhorn Peak quadrangle, Colorado: U.S. Geol. Survey Geol. Quad. Map GQ-1011. 
Luedke, R. G., and Burbank, W. S., 1962, Geology of the Ouray quadrangle, Colorado: U.S. Geol. Survey Geol. Quad. Map GQ-152.

1968, Volcanism and cauldron development in the western San Juan Mountains, Colorado, in Epis, R. C., ed., Cenozoic volcanism in the southern Rocky Mountains: Colorado School Mines Quart., v. 63, no. 3, p. 175-208.

Mayor, J. N., and Fisher, F. S., 1972, Middle Tertiary replacement ore bodies and associated veins in the northwest San Juan Mountains, Colorado: Econ. Geology, v. 67 , no. 2, p. 213-230.

Mehnert, H. H., Lipman, P. W., and Steven, T. A., 1973, Age of the Lake City caldera and related Sunshine Peak Tuff, western San Juan Mountains, Colorado: Isochron West, no. 6, p. 31-33.

Noble, D. C., Smith, V. C., and Peck, L. C., 1967, Loss of halogens from crystallized and glassy silicic volcanic rocks: Geochim. et Cosmochim. Acta, v. 31, no. 2, p. 215-223.

Nockolds, S. R., and Allen, R., 1953, The geochemistry of some igneous rock series, Pt. 1: Geochim. et Cosmochim. Acta, v. 4, no. 3, p. 105-142.

Olson, J. C., Hedlund, D. C., and Hansen, W. R., 1968, Tertiary volcanic stratigraphy in the Powderhorn-Black Canyon region, Gunnison and Montrose Counties, Colorado: U.S. Geol. Survey Bull. 1251-C, 29 p.

Parker, J. M., ed., 1962, Colorado-Nebraska oil and gas field volume, 1961: Rocky Mtn. Assoc. Geologists, 390 p.

Pearl, R. H., 1972, Geothermal resources of Colorado: Colorado Geol. Survey Spec. Pub. 2, 54 p.

Plouff, Donald, and Pakiser, L. C., 1972, Gravity study of the San Juan Mountains, Colorado, in Geological Survey research 1972: U.S. Geol. Survey Prof. Paper 800-B, p. B183-B190.

Popenoe, Peter, and Luedke, R. G., 1970, Interpretation of the aeromagnetic pattern of the Uncompahgre Primitive Area, San Juan Mountains, Colorado: U.S. Geol. Survey open-file report.

Purington, C. W., 1898, Preliminary report on mining industries of the Telluride quadrangle, Colorado: U.S. Geol. Survey 18th Ann. Rept., pt. 3, p. 745-850.

Ratté, J. C., and Steven, T. A., 1967, Ash flows and related volcanic rocks associated with the Creede caldera, San Juan Mountains, Colorado: U.S. Geol. Survey Prof. Paper 524- $\mathrm{H}, 58 \mathrm{p}$.

Rosholt, J. N., and Noble, D. S., 1969, Loss of uranium from crystallized silicic volcanic rocks: Earth and Planetary Sci. Letters, v. 6, no. 4, p. 268-270.

Staatz, M. H., 1963, Geology of the beryllium deposits in the Thomas Range, Juab County, Utah: U.S. Geol. Survey Bull. 1142-M, 36 p.

Staatz, M. H., and Griffitts, W. R., 1961, Beryllium-bearing tuff in the Thomas Range, Juab County, Utah: Econ. Geology, v. 56, no. 5, p. 941-958.

Steven, T. A., 1960, Geology and fluorspar deposits, Northgate district, Colorado: U.S. Geol. Survey Bull. 1082-F, p. 323-422.

Steven, T. A., and Epis, R. C., 1968, Oligocene volcanism in south-central Colorado, in Epis, R. C., ed., Cenozoic volcanism in the southern Rocky Mountains: Colorado School Mines Quart., v. 63, no. 3, p. 241-258.

Steven, T. A., Luedke, R. G., and Lipman, P. W., 1974, Relation of mineralization to calderas in the San Juan volcanic field, southwestern Colorado: U.S. Geol. Survey Jour. Research, v. 2, no. 4, p. 405-409.

Steven, T. A., Mehnert, H. H., and Obradovich, J. D., 1967, Age of volcanic activity in the San Juan Mountains, Colorado, in Geological Survey research 1967: U.S. Geol. Survey Prof. Paper 575-D, p. D47-D55.

Steven, T. A., and others, 1973, Magnetic tape containing spectrographic and chemical analyses of rocks and stream sediment from the study areas contiguous to the Un- 
compahgre Primitive Area, Colorado: U.S. Dept. Commerce, Natl. Tech. Inf. Service, Springfield, Va. 22161, PB220-818.

Turekian, K. K., and Wedepohl, K. H., 1961, Distribution of the elements in some major units of the Earth's crust: Geol. Soc. America Bull., v. 72, no. 2, p. 175-191.

U.S. Geological Survey, 1972, Aeromagnetic map of the Ridgeway-Pagosa Springs area, southwestern Colorado: U.S. Geol. Survey Geophys. Inv. Map GP-840.

Vanderwilt, J. W, ed., 1947, Mineral resources of Colorado: Colorado Mineral Resources Board, $547 \mathrm{p}$.

Vine, J. D., and Tourtelot, E. B., 1970, Geochemistry of black shale deposits-a summary report: Econ. Geology, v. 65, p. 253-272.

White, D. E., 1965, Geothermal energy: U.S. Geol. Survey Circ. 519, 17 p.

Zietz, Isidore, and Kirby, J. R., 1972, Aeromagnetic map of Colorado: U.S. Geol. Survey Geophys. Inv. Map GP-880. 
. 


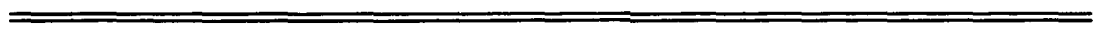

TABLES 5-8, 11 
TABLE 5.-Analyses of stream-sediment

[See plate $2 A$ for sample localities. ppm, parts per million; $\mathbf{N}$, not detected; L, detected but below lower limit looked for in spectrographic analyses, and either not found or found in amounts normal for the type Co (5), Cr (10), La (20), Ni (5), Sb (100), Sc (5), Sn (10), Sr (100), V (10), W (50), Y (10), and Zr (10)]

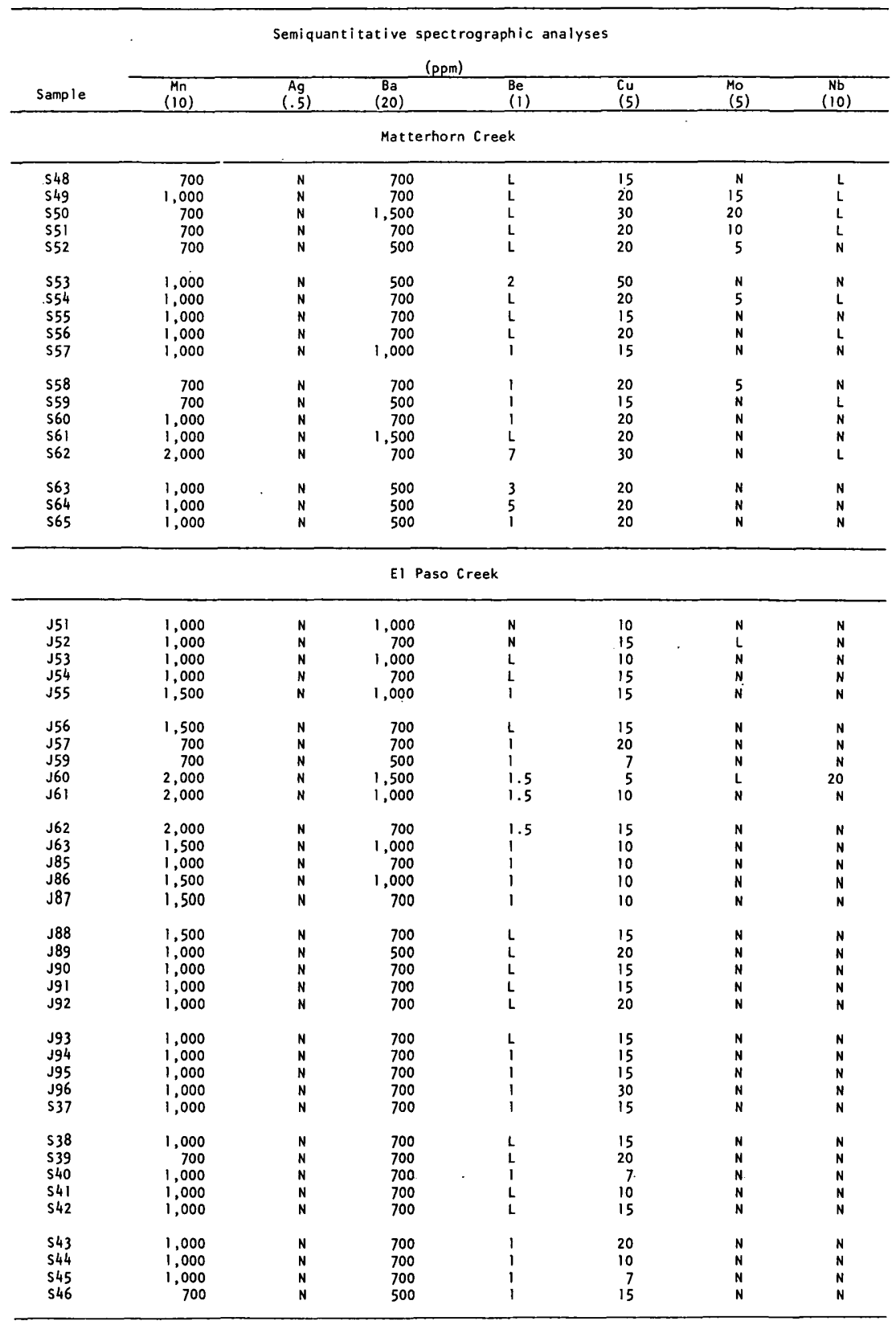




\section{samples from the eastern contiguous area}

of measurement. Number in parentheses below element symbol is the usual lower limit of determination. Also of material sampled, were Fe (0.05), $\mathrm{Mg}(0.02)$, Ca (0.05), Ti (0.002), As (200), Au (10), B (10), Bi (10), Cd (20),

\begin{tabular}{|c|c|c|c|c|c|c|c|}
\hline \multirow[b]{2}{*}{ Sample } & \multicolumn{3}{|c|}{$\begin{array}{c}\text { Semiquant i tat ive spect rographic } \\
\text { analyses--Cont inued } \\
\text { (ppm) }\end{array}$} & \multicolumn{4}{|c|}{$\begin{array}{c}\text { Chemical analyses } \\
(\mathrm{ppm})\end{array}$} \\
\hline & $\begin{array}{l}\mathrm{Pb} \\
(10) \\
\end{array}$ & $\begin{array}{c}\overline{s r} \\
(100) \\
\end{array}$ & $\begin{array}{l}2 n \\
(200) \\
\end{array}$ & $\begin{array}{l}\text { Au } \\
(.05)\end{array}$ & $\begin{array}{r}\mathrm{C} \times \mathrm{Cu} \\
(1) \\
\end{array}$ & $\begin{array}{r}\mathrm{CXHM} \\
(1)\end{array}$ & $\begin{array}{l}56 \\
(.5) \\
\end{array}$ \\
\hline \multicolumn{8}{|c|}{ Matterhorn Creek--Continued } \\
\hline $\begin{array}{l}548 \\
549 \\
550 \\
551 \\
\$ 52\end{array}$ & $\begin{array}{l}50 \\
70 \\
70 \\
70 \\
20\end{array}$ & $\begin{array}{l}500 \\
300 \\
300 \\
300 \\
150\end{array}$ & $\begin{array}{l}\mathrm{N} \\
\mathrm{N} \\
\mathrm{N} \\
\mathrm{N} \\
\mathrm{N}\end{array}$ & $\begin{array}{l}\mathrm{N} \\
\mathrm{N} \\
\mathrm{N} \\
\mathrm{N} \\
\mathrm{N}\end{array}$ & $\begin{array}{l}3 \\
4 \\
4 \\
2 \\
4\end{array}$ & $\begin{array}{l}3 \\
4 \\
1 \\
L \\
N\end{array}$ & $\begin{array}{l}2 \\
2 \\
3 \\
2 \\
1\end{array}$ \\
\hline $\begin{array}{l}553 \\
\$ 54 \\
555 \\
556 \\
557\end{array}$ & $\begin{array}{l}30 \\
20 \\
20 \\
30 \\
30\end{array}$ & $\begin{array}{l}200 \\
300 \\
500 \\
500 \\
500\end{array}$ & $\begin{array}{l}N \\
N \\
N \\
N \\
L\end{array}$ & $\begin{array}{l}N \\
N \\
N \\
N \\
N\end{array}$ & $\begin{array}{l}4 \\
6 \\
3 \\
4 \\
4\end{array}$ & $\begin{array}{l}N \\
\mathrm{~L} \\
\mathrm{I} \\
2 \\
2\end{array}$ & $\begin{array}{l}1 \\
2 \\
1^{.} .5 \\
2\end{array}$ \\
\hline $\begin{array}{l}558 \\
559 \\
560 \\
561 \\
562\end{array}$ & $\begin{array}{l}30 \\
20 \\
30 \\
30 \\
20\end{array}$ & $\begin{array}{l}300 \\
300 \\
300 \\
300 \\
500\end{array}$ & $\begin{array}{r}N \\
N \\
200 \\
200 \\
500\end{array}$ & $\begin{array}{l}\text { N } \\
\text { N } \\
\text { N } \\
\text { N } \\
\text { N }\end{array}$ & $\begin{array}{r}3 \\
3 \\
8 \\
8 \\
10\end{array}$ & $\begin{array}{r}N \\
N \\
7 \\
5 \\
40\end{array}$ & $\begin{array}{l}2 \\
2 \\
2 \\
1 \\
3\end{array}$ \\
\hline $\begin{array}{l}563 \\
564 \\
565\end{array}$ & $\begin{array}{l}20 \\
20 \\
20\end{array}$ & $\begin{array}{l}500 \\
300 \\
300\end{array}$ & $\begin{array}{r}300 \\
300 \\
\text { N }\end{array}$ & $\begin{array}{l}\mathrm{N} \\
\mathrm{N} \\
\mathrm{N}\end{array}$ & $\begin{array}{l}8 \\
8 \\
8\end{array}$ & $\begin{array}{r}17 \\
20 \\
5\end{array}$ & $\begin{array}{l}4 \\
3 \\
2\end{array}$ \\
\hline
\end{tabular}

El Paso Creek--Continued

\begin{tabular}{|c|c|c|c|c|c|c|c|}
\hline $\begin{array}{l}\mathrm{J} 51 \\
\mathrm{~J} 52 \\
\mathrm{~J} 53 \\
\mathrm{~J} 54 \\
\mathrm{~J} 55\end{array}$ & $\begin{array}{l}50 \\
70 \\
70 \\
50 \\
50\end{array}$ & $\begin{array}{l}700 \\
500 \\
500 \\
500 \\
500\end{array}$ & $\begin{array}{l}\mathrm{N} \\
\mathrm{N} \\
\mathrm{N} \\
\mathrm{N} \\
\mathrm{N}\end{array}$ & $\begin{array}{l}\mathrm{N} \\
\mathrm{N} \\
\mathrm{N} \\
\mathrm{N} \\
\mathrm{N}\end{array}$ & $\begin{array}{l}4 \\
4 \\
6 \\
8 \\
6\end{array}$ & $\begin{array}{l}N \\
1 \\
3 \\
4 \\
\text { L }\end{array}$ & $\begin{array}{l}1 \\
1.5 \\
1\end{array}$ \\
\hline $\begin{array}{l}\mathrm{J} 56 \\
\mathrm{~J} 57 \\
\mathrm{~J} \\
\mathrm{~J} \\
\mathrm{~J} 60 \\
\mathrm{~J}\end{array}$ & $\begin{array}{l}70 \\
30 \\
30 \\
70 \\
50\end{array}$ & $\begin{array}{l}500 \\
500 \\
200 \\
500 \\
300\end{array}$ & $\begin{array}{l}\mathrm{N} \\
\mathrm{N} \\
\mathrm{N} \\
\mathrm{N} \\
\mathrm{N}\end{array}$ & $\begin{array}{l}\text { N } \\
\text { N } \\
\text { N } \\
\text { N } \\
\text { N }\end{array}$ & $\begin{array}{l}3 \\
3 \\
4 \\
2 \\
1\end{array}$ & $\begin{array}{l}2 \\
\mathrm{~N} \\
4 \\
\mathrm{~N} \\
1\end{array}$ & $\begin{array}{l}.5 \\
1 \\
2^{2} \\
.5\end{array}$ \\
\hline $\begin{array}{l}J 62 \\
J 63 \\
J 85 \\
J 86 \\
J 87\end{array}$ & $\begin{array}{l}50 \\
50 \\
50 \\
50 \\
50\end{array}$ & $\begin{array}{l}300 \\
500 \\
300 \\
300 \\
500\end{array}$ & $\begin{array}{l}\mathbf{N} \\
\mathbf{N} \\
\mathbf{N} \\
\mathbf{N}\end{array}$ & $\begin{array}{l}N \\
N \\
N \\
N \\
N \\
N\end{array}$ & $\begin{array}{l}2 \\
L \\
1 \\
N \\
2\end{array}$ & $\begin{array}{r}2 \\
N \\
L \\
N \\
14\end{array}$ & $\begin{array}{l}1.5 \\
.5 \\
.5\end{array}$ \\
\hline $\begin{array}{l}J 88 \\
J 89 \\
J 90 \\
J 91 \\
J 92\end{array}$ & $\begin{array}{l}50 \\
30 \\
50 \\
50 \\
50\end{array}$ & $\begin{array}{l}500 \\
500 \\
500 \\
500 \\
500\end{array}$ & $\begin{array}{l}\text { N } \\
\text { N } \\
\text { N } \\
\text { N }\end{array}$ & $\begin{array}{l}N \\
N \\
N \\
N \\
N\end{array}$ & $\begin{array}{l}1 \\
1 \\
1 \\
L \\
4\end{array}$ & $\begin{array}{l}N \\
N \\
N \\
N \\
L \\
L\end{array}$ & $\begin{array}{l}.5 \\
1 \\
1 \\
1\end{array}$ \\
\hline $\begin{array}{l}\mathrm{Jg3} \\
\mathrm{Jg4} \\
\mathrm{J} 95 \\
\mathrm{~J} 96 \\
\mathrm{~s} 37\end{array}$ & $\begin{array}{r}50 \\
50 \\
30 \\
100 \\
30\end{array}$ & $\begin{array}{l}500 \\
300 \\
300 \\
300 \\
300\end{array}$ & $\begin{array}{l}\mathrm{N} \\
\mathrm{N} \\
\mathrm{N} \\
\mathrm{N} \\
\mathrm{N}\end{array}$ & $\begin{array}{l}\mathrm{N} \\
\mathrm{N} \\
\mathrm{N} \\
\mathrm{N} \\
\mathrm{N}\end{array}$ & $\begin{array}{l}4 \\
3 \\
2 \\
8 \\
4\end{array}$ & $\begin{array}{r}4 \\
3 \\
5 \\
11 \\
2\end{array}$ & $\begin{array}{l}1 \\
1 \\
1 \\
2 \\
3\end{array}$ \\
\hline $\begin{array}{l}538 \\
539 \\
540 \\
541 \\
542\end{array}$ & $\begin{array}{l}50 \\
30 \\
50 \\
50 \\
30\end{array}$ & $\begin{array}{l}300 \\
300 \\
300 \\
300 \\
500\end{array}$ & $\begin{array}{l}\mathrm{N} \\
\mathrm{N} \\
\mathrm{N} \\
\mathrm{N} \\
\mathrm{N}\end{array}$ & $\begin{array}{l}\mathrm{N} \\
\mathrm{N} \\
\mathrm{N} \\
\mathrm{N} \\
\mathrm{N}\end{array}$ & $\begin{array}{l}2 \\
4 \\
2 \\
2 \\
1\end{array}$ & $\begin{array}{l}4 \\
1 \\
5 \\
2 \\
N\end{array}$ & $\begin{array}{l}3 \\
1 \\
1 \\
1 \\
{ }^{5} 5\end{array}$ \\
\hline $\begin{array}{l}543 \\
544 \\
545 \\
546\end{array}$ & $\begin{array}{r}50 \\
50 \\
20 \\
100\end{array}$ & $\begin{array}{l}300 \\
300 \\
300 \\
300\end{array}$ & $\begin{array}{l}\text { N } \\
N \\
N \\
N \\
N\end{array}$ & $\begin{array}{l}\mathrm{N} \\
\mathrm{N} \\
\mathrm{N} \\
\mathrm{N}\end{array}$ & $\begin{array}{l}3 \\
2 \\
3 \\
8\end{array}$ & $\begin{array}{r}2 \\
4 \\
2 \\
14\end{array}$ & $\begin{array}{l}1 \\
1 \\
1 \\
2\end{array}$ \\
\hline
\end{tabular}


TABLE 5.-Analyses of stream-sediment samples

\begin{tabular}{|c|c|c|c|c|c|c|c|}
\hline \multirow[b]{2}{*}{ Sample } & \multicolumn{5}{|c|}{$\begin{array}{r}\text { Semiquantitative spectrographic analyses } \\
(\mathrm{ppm})\end{array}$} & \multirow[b]{2}{*}{$\begin{array}{l}\text { Mo } \\
\text { (5) }\end{array}$} & \multirow[b]{2}{*}{$\begin{array}{c}\mathrm{Nb} \\
(10) \\
\end{array}$} \\
\hline & $\begin{array}{c}M n \\
(10)\end{array}$ & $\begin{array}{c}\mathrm{Ag} \\
(.5)\end{array}$ & $\begin{array}{c}8 \mathrm{Ba} \\
(20) \\
\end{array}$ & $\begin{array}{l}\mathrm{Be} \\
\text { (1) }\end{array}$ & $\begin{array}{l}\mathrm{Cu} \\
(5) \\
\end{array}$ & & \\
\hline \multicolumn{8}{|c|}{ East Fork Cimarron River } \\
\hline $\begin{array}{l}54 \\
55 \\
56 \\
57 \\
58\end{array}$ & $\begin{array}{r}1,000 \\
1,000 \\
1,000 \\
700 \\
700\end{array}$ & $\begin{array}{l}\mathrm{N} \\
\mathrm{N} \\
\mathrm{N} \\
\mathrm{N} \\
\mathrm{N}\end{array}$ & $\begin{array}{l}500 \\
700 \\
700 \\
500 \\
700\end{array}$ & $\begin{array}{l}N \\
N \\
L \\
L \\
L\end{array}$ & $\begin{array}{l}30 \\
20 \\
20 \\
20 \\
20\end{array}$ & $\begin{array}{l}\mathbf{N} \\
\mathbf{N} \\
\mathbf{N} \\
\mathbf{N} \\
\mathbf{N}\end{array}$ & $\begin{array}{l}N \\
N \\
N \\
N \\
L\end{array}$ \\
\hline $\begin{array}{r}59 \\
10 \\
s 11 \\
512 \\
513\end{array}$ & $\begin{array}{l}1,000 \\
1,000 \\
1,000 \\
1,500 \\
1,500\end{array}$ & $\begin{array}{l}N \\
N \\
N \\
N \\
N\end{array}$ & $\begin{array}{l}1,000 \\
1,000 \\
1,000 \\
1,000 \\
1,000\end{array}$ & $\begin{array}{l}\mathrm{L} \\
\mathrm{N} \\
\mathrm{L} \\
\mathrm{L} \\
\mathrm{I}\end{array}$ & $\begin{array}{l}15 \\
20 \\
30 \\
20 \\
20\end{array}$ & $\begin{array}{l}N \\
N \\
N \\
N \\
N\end{array}$ & $\begin{array}{l}\mathbf{N} \\
\mathbf{N} \\
\mathbf{N} \\
\mathbf{N} \\
\mathbf{N}\end{array}$ \\
\hline $\begin{array}{l}514 \\
515 \\
516 \\
517 \\
518\end{array}$ & $\begin{array}{l}1,000 \\
1,000 \\
1,000 \\
1,000 \\
1,000\end{array}$ & $\begin{array}{l}N \\
N \\
N \\
N \\
N\end{array}$ & $\begin{array}{r}1,000 \\
700 \\
1,000 \\
1,000 \\
1,000\end{array}$ & $\begin{array}{l}\mathrm{L} \\
\mathrm{L} \\
\mathrm{L} \\
\mathrm{L} \\
\mathrm{L}\end{array}$ & $\begin{array}{l}20 \\
20 \\
20 \\
15 \\
20\end{array}$ & $\begin{array}{l}\mathbf{N} \\
\mathbf{N} \\
\mathbf{N} \\
\mathbf{N} \\
\mathbf{N}\end{array}$ & $\begin{array}{l}\mathbf{N} \\
\mathbf{N} \\
\mathbf{N} \\
\mathbf{N} \\
\mathbf{N}\end{array}$ \\
\hline $\begin{array}{l}\$ 19 \\
520 \\
\$ 21 \\
\$ 22 \\
\$ 23\end{array}$ & $\begin{array}{l}1,000 \\
1,000 \\
1,000 \\
1,000 \\
1,000\end{array}$ & $\begin{array}{l}N \\
N \\
N \\
N \\
N\end{array}$ & $\begin{array}{l}1,000 \\
1,000 \\
1,000 \\
1,000 \\
1,000\end{array}$ & $\begin{array}{l}\mathrm{L} \\
\mathrm{L} \\
\mathrm{L} \\
\mathrm{L} \\
\mathrm{L}\end{array}$ & $\begin{array}{l}20 \\
30 \\
30 \\
20 \\
15\end{array}$ & $\begin{array}{l}\mathbf{N} \\
\mathbf{N} \\
\mathbf{N} \\
\mathbf{N} \\
\mathbf{N}\end{array}$ & $\begin{array}{l}N \\
N \\
N \\
N \\
N\end{array}$ \\
\hline $\begin{array}{l}\$ 24 \\
\$ 25 \\
\$ 26 \\
\$ 27 \\
\$ 28\end{array}$ & $\begin{array}{l}1,000 \\
1,000 \\
1,000 \\
1,000 \\
1,500\end{array}$ & $\begin{array}{l}\mathrm{N} \\
\mathrm{N} \\
\mathrm{N} \\
\mathrm{N} \\
\mathrm{N}\end{array}$ & $\begin{array}{r}700 \\
1,000 \\
1,000 \\
700 \\
1,500\end{array}$ & $\begin{array}{l}\mathrm{L} \\
\mathrm{N} \\
\mathrm{N} \\
\mathrm{N} \\
\mathrm{N}\end{array}$ & $\begin{array}{l}20 \\
15 \\
50 \\
30 \\
20\end{array}$ & $\begin{array}{l}i ! \\
N \\
N \\
N \\
N\end{array}$ & $\begin{array}{l}\mathbf{N} \\
\mathbf{N} \\
\mathbf{N} \\
\mathbf{N} \\
\mathbf{N}\end{array}$ \\
\hline $\begin{array}{l}\$ 29 \\
530 \\
531 \\
532 \\
533\end{array}$ & $\begin{array}{r}1,000 \\
700 \\
1,000 \\
700 \\
1,000\end{array}$ & $\begin{array}{l}\mathbf{N} \\
\mathbf{N} \\
\mathbf{N} \\
\mathbf{N} \\
\mathbf{N}\end{array}$ & $\begin{array}{l}1,000 \\
1,000 \\
1,000 \\
700 \\
1,500\end{array}$ & $\begin{array}{l}N \\
N \\
N \\
N \\
N\end{array}$ & $\begin{array}{l}20 \\
10 \\
20 \\
10 \\
15\end{array}$ & $\begin{array}{l}\mathrm{N} \\
\mathrm{N} \\
\mathrm{N} \\
\mathrm{N} \\
\mathrm{N}\end{array}$ & $\begin{array}{l}\mathbf{N} \\
\mathbf{N} \\
\mathbf{N} \\
\mathbf{N} \\
\mathbf{N}\end{array}$ \\
\hline $\begin{array}{r}.534 \\
535 \\
6146 \\
6147 \\
G 148\end{array}$ & $\begin{array}{l}1,500 \\
1,000 \\
1,000 \\
1,000 \\
1,000\end{array}$ & $\begin{array}{l}N \\
N \\
N \\
N \\
N\end{array}$ & $\begin{array}{r}700 \\
700 \\
1,000 \\
1,000 \\
700\end{array}$ & $\begin{array}{l}N \\
N \\
L \\
\text { L }\end{array}$ & $\begin{array}{l}20 \\
15 \\
10 \\
20 \\
15\end{array}$ & $\begin{array}{l}N \\
N \\
N \\
N \\
N\end{array}$ & $\begin{array}{l}\mathbf{N} \\
\mathbf{N} \\
\mathbf{N} \\
\mathbf{N} \\
\mathbf{N}\end{array}$ \\
\hline $\begin{array}{l}G 149 \\
G 150 \\
G 151 \\
G 152 \\
G 153\end{array}$ & $\begin{array}{l}1,000 \\
1,000 \\
1,500 \\
1,500 \\
1,000\end{array}$ & $\begin{array}{l}\mathbf{N} \\
\mathbf{N} \\
\mathrm{N} \\
\mathrm{N} \\
\mathbf{N}\end{array}$ & $\begin{array}{l}1,000 \\
1,000 \\
1,000 \\
1,000 \\
1,000\end{array}$ & $\begin{array}{l}1 \\
L \\
L \\
L\end{array}$ & $\begin{array}{l}15 \\
20 \\
15 \\
20 \\
15\end{array}$ & $\begin{array}{l}N \\
N \\
N \\
N \\
N\end{array}$ & $\begin{array}{l}\mathbf{N} \\
\mathbf{N} \\
\mathbf{N} \\
\mathbf{N} \\
\mathbf{N}\end{array}$ \\
\hline $\begin{array}{l}\text { G154 } \\
\text { G155 } \\
\text { G156 } \\
\text { G157 } \\
\text { G158 }\end{array}$ & $\begin{array}{l}1,000 \\
1,000 \\
1,000 \\
700 \\
1,000\end{array}$ & $\begin{array}{l}\mathbf{N} \\
\mathbf{N} \\
\mathbf{N} \\
\mathbf{N} \\
\mathbf{N}\end{array}$ & $\begin{array}{r}1,000 \\
1.000 \\
700 \\
700 \\
1,000\end{array}$ & $\begin{array}{l}L \\
L \\
L \\
L \\
N\end{array}$ & $\begin{array}{l}15 \\
20 \\
15 \\
10 \\
10\end{array}$ & $\begin{array}{l}N \\
N \\
N \\
N \\
N\end{array}$ & $\begin{array}{l}\mathbf{N} \\
\mathbf{N} \\
\mathbf{N} \\
\mathbf{N} \\
\mathbf{N}\end{array}$ \\
\hline $\begin{array}{l}G 159 \\
G 160 \\
G 161 \\
G 162 \\
G 163\end{array}$ & $\begin{array}{l}1,000 \\
1,000 \\
1,000 \\
1,000 \\
1,000\end{array}$ & $\begin{array}{l}N \\
N \\
N \\
N \\
N\end{array}$ & $\begin{array}{r}1,000 \\
700 \\
700 \\
700 \\
700\end{array}$ & $\begin{array}{l}L \\
L \\
L \\
L \\
L\end{array}$ & $\begin{array}{l}15 \\
20 \\
15 \\
15 \\
10\end{array}$ & $\begin{array}{l}N \\
N \\
N \\
N \\
N\end{array}$ & $\begin{array}{l}N \\
N \\
N \\
N \\
N\end{array}$ \\
\hline $\begin{array}{l}0164 \\
6165 \\
G 166 \\
5167 \\
G 168\end{array}$ & $\begin{array}{l}1,000 \\
1,000 \\
1,000 \\
1,000 \\
1,000\end{array}$ & $\begin{array}{l}\mathrm{N} \\
\mathrm{N} \\
\mathrm{N} \\
\mathrm{N} \\
\mathrm{N}\end{array}$ & $\begin{array}{r}500 \\
700 \\
1,000 \\
700 \\
700\end{array}$ & $\begin{array}{l}\text { N } \\
L \\
L \\
L \\
L\end{array}$ & $\begin{array}{r}15 \\
15 \\
15 \\
7 \\
15\end{array}$ & $\begin{array}{l}N \\
N \\
N \\
N \\
N\end{array}$ & $\begin{array}{l}N \\
N \\
N \\
N \\
N\end{array}$ \\
\hline $\begin{array}{l}6169 \\
6170 \\
6171 \\
6172 \\
6173\end{array}$ & $\begin{array}{l}1,000 \\
1,000 \\
1,000 \\
1,000 \\
1,500\end{array}$ & $\begin{array}{l}\mathrm{N} \\
\mathrm{N} \\
\mathrm{N} \\
\mathrm{N} \\
\mathrm{N}\end{array}$ & $\begin{array}{r}700 \\
700 \\
1,000 \\
700 \\
700\end{array}$ & $\begin{array}{l}N \\
L \\
L \\
L \\
N\end{array}$ & $\begin{array}{l}15 \\
15 \\
15 \\
15 \\
15\end{array}$ & $\begin{array}{l}\mathbf{N} \\
\mathbf{N} \\
\mathbf{N} \\
\mathrm{N} \\
\mathrm{N}\end{array}$ & $\begin{array}{l}N \\
N \\
N \\
N\end{array}$ \\
\hline 6174 & 1.500 & $N$ & 700 & $\mathrm{~N}$ & 20 & $N$ & $\mathbf{N}$ \\
\hline
\end{tabular}


CONTIGUOUS AREAS, UNCOMPAHGRE PRIMITIVE AREA, COLO. E95

from the eastern contiguous area-Continued

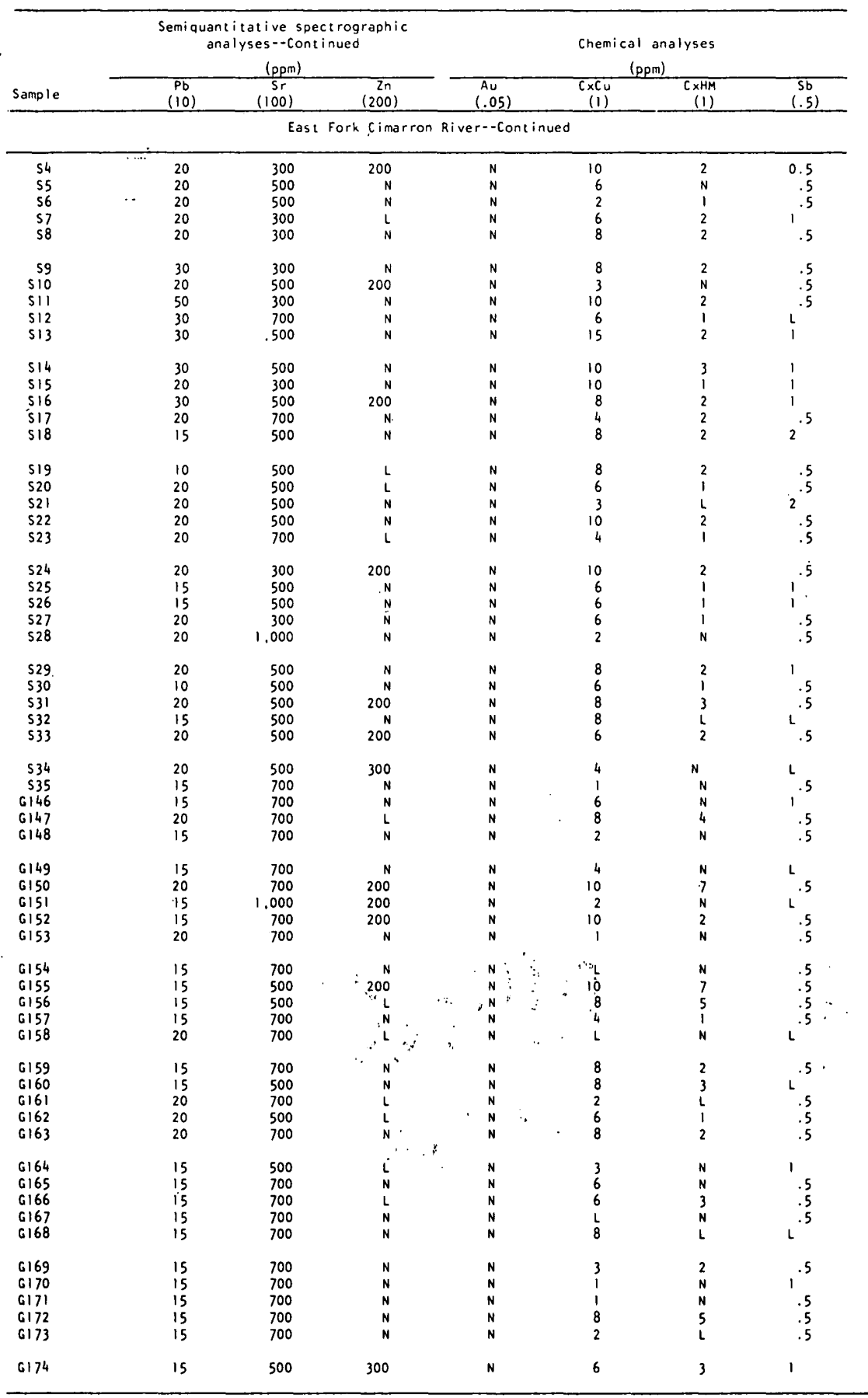


TABLE 6.-Analyses of rock samples from

[See plate $2 A$ for sample localities. ppm, parts per million, $\mathbf{N}$, not detected, L, detected but below lower looked for in spectrographic analyses, and either not found or found in amounts normal for the type La (20), Ni (5), Sb (100), Sc (5), Sn (10), V (10), W (50), Y (10), and Zr (10)]

\begin{tabular}{|c|c|c|c|c|c|c|c|c|c|c|c|c|}
\hline \multirow[b]{2}{*}{ Samp le } & \multicolumn{10}{|c|}{$\begin{array}{r}\text { Semiquantitative spectrographic analyses } \\
(\mathrm{ppm})\end{array}$} & \multirow[b]{2}{*}{$\begin{array}{c}S r \\
(100)\end{array}$} & \multirow[b]{2}{*}{$\begin{array}{r}2 n \\
(200) \\
\end{array}$} \\
\hline & $\begin{array}{c}M n \\
(10) \\
\end{array}$ & $\begin{array}{c}\mathrm{Ag} \\
(.5) \\
\end{array}$ & $\begin{array}{c}8 a \\
(20) \\
\end{array}$ & $\begin{array}{c}8 \mathrm{i} \\
(10) \\
\end{array}$ & $\begin{array}{r}c d \\
(20) \\
\end{array}$ & $\begin{array}{l}\text { Co } \\
(5)\end{array}$ & $\begin{array}{l}\mathrm{Cu} \\
(5) \\
\end{array}$ & $\begin{array}{l}\text { Mo } \\
(5) \\
\end{array}$ & $\begin{array}{c}\mathrm{Nb} \\
(20)\end{array}$ & $\begin{array}{c}\mathrm{Pb} \\
(10)\end{array}$ & & \\
\hline \multicolumn{13}{|c|}{ Cimarron altered area } \\
\hline $\begin{array}{l}S 85 A \\
S 85 B \\
585 C \\
S 850 \\
S 85 E\end{array}$ & $\begin{array}{r}300 \\
1,000 \\
1,000 \\
1,000 \\
200\end{array}$ & $\begin{array}{l}N \\
N \\
N \\
N \\
N\end{array}$ & $\begin{array}{r}100 \\
1,000 \\
1,000 \\
1,000 \\
1,000\end{array}$ & $\begin{array}{l}\mathrm{N} \\
\mathrm{N} \\
\mathrm{N} \\
\mathrm{N} \\
\mathrm{N}\end{array}$ & $\begin{array}{l}\mathrm{N} \\
\mathrm{N} \\
\mathrm{N} \\
\mathrm{N} \\
\mathrm{N}\end{array}$ & $\begin{array}{r}7 \\
L \\
15 \\
15 \\
L\end{array}$ & $\begin{array}{r}1 \\
7 \\
50 \\
70 \\
10\end{array}$ & $\begin{array}{l}N \\
N \\
N \\
N \\
N\end{array}$ & $\begin{array}{r}20 \\
N \\
N \\
N \\
L\end{array}$ & $\begin{array}{l}70 \\
15 \\
50 \\
20 \\
30\end{array}$ & $\begin{array}{r}150 \\
500 \\
500 \\
1,000 \\
300\end{array}$ & $\begin{array}{l}\mathbf{N} \\
\mathbf{N} \\
\mathbf{N} \\
\mathrm{N} \\
\mathrm{N}\end{array}$ \\
\hline $\begin{array}{l}S 85 F \\
S 85 G \\
S 85 H \\
S 851 \\
S 85 J\end{array}$ & $\begin{array}{r}700 \\
700 \\
700 \\
1,000 \\
1,000\end{array}$ & $\mathrm{~N}_{\mathrm{N}}^{.5}$ & $\begin{array}{r}1,000 \\
1,000 \\
700 \\
1,000 \\
700\end{array}$ & $\begin{array}{l}N \\
N \\
N \\
N \\
N\end{array}$ & $\begin{array}{l}N \\
N \\
N \\
N \\
N\end{array}$ & $\begin{array}{r}\mathrm{L} \\
\mathrm{L} \\
\mathrm{N} \\
5 \\
10\end{array}$ & $\begin{array}{r}20 \\
20 \\
7 \\
15 \\
50\end{array}$ & $\begin{array}{r}\text { N } \\
N \\
10 \\
5 \\
7\end{array}$ & $\begin{array}{l}\mathrm{L} \\
\mathrm{L} \\
\mathrm{L} \\
\mathrm{L} \\
\mathrm{L}\end{array}$ & $\begin{array}{l}150 \\
100 \\
100 \\
100 \\
70\end{array}$ & $\begin{array}{l}500 \\
500 \\
300 \\
500 \\
500\end{array}$ & $\begin{array}{l}\mathrm{N} \\
\mathrm{N} \\
\mathrm{N} \\
\mathrm{N} \\
\mathrm{N}\end{array}$ \\
\hline $\begin{array}{l}S 86 A \\
S 86 B \\
S 86 C \\
5860 \\
S 86 E\end{array}$ & $\begin{array}{r}1,000 \\
1,500 \\
1,500 \\
1,000 \\
150\end{array}$ & $\begin{array}{l}N \\
N \\
N \\
N \\
1\end{array}$ & $\begin{array}{r}1,500 \\
700 \\
1,000 \\
1,500 \\
300\end{array}$ & $\begin{array}{l}N \\
N \\
N \\
N \\
N\end{array}$ & $\begin{array}{l}N \\
N \\
N \\
N \\
N\end{array}$ & $\begin{array}{l}10 \\
15 \\
15 \\
10 \\
10\end{array}$ & $\begin{array}{r}20 \\
5 \\
5 \\
7 \\
5\end{array}$ & $\begin{array}{c}N \\
N \\
N \\
N \\
15\end{array}$ & $\begin{array}{l}N \\
N \\
N \\
N \\
L\end{array}$ & $\begin{array}{l}20 \\
20 \\
70 \\
15 \\
70\end{array}$ & $\begin{array}{r}1,000 \\
700 \\
1,500 \\
1,000 \\
\mathrm{~N}\end{array}$ & $\begin{array}{l}\mathrm{N} \\
\mathrm{N} \\
\mathrm{N} \\
\mathrm{N} \\
\mathrm{N}\end{array}$ \\
\hline $\begin{array}{r}S 86 F \\
S 86 G \\
S 86 H \\
S 861 \\
S 170 A\end{array}$ & $\begin{array}{l}1,000 \\
1,000 \\
2,000 \\
1,000 \\
1,500\end{array}$ & $\begin{array}{l}\mathrm{L} \\
\mathrm{N} \\
7 \\
\mathrm{~N} \\
\mathrm{~N}\end{array}$ & $\begin{array}{r}2,000 \\
700 \\
300 \\
1,000 \\
1,500\end{array}$ & $\begin{array}{l}N \\
N \\
N \\
N \\
N\end{array}$ & $\begin{array}{l}\mathbf{N} \\
\mathrm{N} \\
\mathrm{N} \\
\mathrm{N} \\
\mathrm{N}\end{array}$ & $\begin{array}{r}20 \\
10 \\
20 \\
5 \\
20\end{array}$ & $\begin{array}{l}70 \\
L \\
20 \\
20 \\
15\end{array}$ & $\begin{array}{r}10 \\
N \\
15 \\
7 \\
N\end{array}$ & $\begin{array}{l}L \\
L \\
N \\
L \\
L\end{array}$ & $\begin{array}{r}100 \\
20 \\
1,000 \\
70 \\
20\end{array}$ & $\begin{array}{r}300 \\
500 \\
500 \\
300 \\
1,000\end{array}$ & $\begin{array}{r}\mathbf{N} \\
\mathbf{N} \\
700 \\
\mathbf{N} \\
\mathrm{N}\end{array}$ \\
\hline $\begin{array}{l}S 170 B \\
\$ 171 \\
S 172 \\
S 173 \\
S 174\end{array}$ & $\begin{array}{r}1,000 \\
100 \\
70 \\
70 \\
300\end{array}$ & $\begin{array}{l}\mathrm{N} \\
\mathrm{L} \\
\mathrm{N} \\
\mathrm{N} \\
\mathrm{N}\end{array}$ & $\begin{array}{r}1,000 \\
1,000 \\
1,500 \\
2,000 \\
700\end{array}$ & $\begin{array}{l}N \\
N \\
N \\
N \\
N\end{array}$ & $\begin{array}{l}N \\
N \\
N \\
N \\
N\end{array}$ & $\begin{array}{l}10 \\
N \\
5 \\
\mathrm{~L} \\
\mathrm{~N}\end{array}$ & $\begin{array}{l}15 \\
10 \\
15 \\
15 \\
15\end{array}$ & $\begin{array}{l}\mathrm{N} \\
\mathrm{N} \\
\mathrm{N} \\
7 \\
\mathrm{~N}\end{array}$ & $\begin{array}{l}\mathrm{L} \\
\mathrm{L} \\
\mathrm{L} \\
\mathrm{L} \\
\mathrm{N}\end{array}$ & $\begin{array}{r}50 \\
20 \\
\quad 15 \\
\because \quad 20 \\
\because \quad 20 \\
\because 34\end{array}$ & $\begin{array}{l}500 \\
300 \\
300 \\
300 \\
300\end{array}$ & $\begin{array}{c}\mathrm{N} \\
\mathrm{N} \\
\mathrm{N} \\
\mathrm{N} \\
\mathrm{N} \\
-\end{array}$ \\
\hline$\$ 175$ & 70 & $N$ & 2,000 & N & $N$ & $\mathbf{N}$ & 10 & 5 & L & $\begin{array}{l}315 \\
\therefore\end{array}$ & 500 & $N$ \\
\hline \multicolumn{13}{|c|}{ Matterhorn altered area } \\
\hline $\begin{array}{l}S 89 A \\
S 89 B \\
S 89 C \\
S 89 E \\
S 89 F\end{array}$ & $\begin{array}{r}500 \\
150 \\
200 \\
1,000 \\
700\end{array}$ & $\begin{array}{l}\mathrm{N} \\
\mathrm{N} \\
\mathrm{N} \\
.7 \\
.5\end{array}$ & $\begin{array}{r}1,000 \\
300 \\
1,000 \\
300 \\
200\end{array}$ & $\begin{array}{l}N \\
L \\
N \\
N \\
N\end{array}$ & $\begin{array}{l}\mathrm{N} \\
\mathrm{N} \\
\mathrm{N} \\
\mathrm{N} \\
\mathrm{N}\end{array}$ & $\begin{array}{r}N \\
N \\
N \\
5 \\
10\end{array}$ & $\begin{array}{r}15 \\
1 \\
5 \\
10 \\
20\end{array}$ & $\begin{array}{c}N \\
5 \\
5 \\
15 \\
15\end{array}$ & $\begin{array}{l}N \\
N \\
N \\
N \\
N\end{array}$ & $\begin{array}{l}20 \\
50 \\
30 \\
70 \\
70\end{array}$ & $\begin{array}{r}200 \\
500 \\
500 \\
300 \\
N\end{array}$ & $\begin{array}{l}N \\
N \\
N \\
L \\
N\end{array}$ \\
\hline $\begin{array}{l}\text { S90B } \\
\text { S91 } \\
\text { S93A } \\
\text { S93B } \\
\text { S93C }\end{array}$ & $\begin{array}{r}1,000 \\
20 \\
30 \\
1,000 \\
700\end{array}$ & $\begin{array}{l}\mathrm{N} \\
\mathrm{N} \\
\mathrm{N} \\
\mathrm{N} \\
\mathrm{N}\end{array}$ & $\begin{array}{r}1,000 \\
700 \\
700 \\
700 \\
700\end{array}$ & $\begin{array}{r}N \\
15 \\
10 \\
N \\
N\end{array}$ & $\begin{array}{l}\mathrm{N} \\
\mathrm{N} \\
\mathrm{N} \\
\mathrm{N} \\
\mathrm{N}\end{array}$ & $\begin{array}{r}15 \\
5 \\
N \\
7 \\
15\end{array}$ & $\begin{array}{r}20 \\
10 \\
L \\
20 \\
30\end{array}$ & $\begin{array}{l}\mathrm{N} \\
7 \\
7 \\
\mathrm{~N} \\
\mathrm{~N}\end{array}$ & $\begin{array}{r}\mathrm{N} \\
\mathrm{L} \\
20 \\
\mathrm{~N} \\
\mathrm{~N}\end{array}$ & $\begin{array}{r}30 \\
1,500 \\
70 \\
20 \\
20\end{array}$ & $\begin{array}{r}700 \\
2,000 \\
1,000 \\
300 \\
500\end{array}$ & $\begin{array}{l}N \\
N \\
N \\
N \\
N\end{array}$ \\
\hline $\begin{array}{r}\text { S930 } \\
\text { S93E } \\
\text { S93F } \\
\text { S94 } \\
\text { S95 }\end{array}$ & $\begin{array}{r}1,000 \\
1,000 \\
700 \\
200 \\
1,000\end{array}$ & $\begin{array}{l}N \\
N \\
N \\
N \\
N\end{array}$ & $\begin{array}{r}700 \\
1,000 \\
1,000 \\
1,500 \\
700\end{array}$ & $\begin{array}{l}N \\
N \\
N \\
N \\
N\end{array}$ & $\begin{array}{l}\mathrm{N} \\
\mathrm{N} \\
\mathrm{N} \\
\mathrm{N} \\
\mathrm{N}\end{array}$ & $\begin{array}{r}10 \\
10 \\
7 \\
L \\
30\end{array}$ & $\begin{array}{l}50 \\
20 \\
20 \\
10 \\
15\end{array}$ & $\begin{array}{c}5 \\
N \\
N \\
15 \\
N\end{array}$ & $\begin{array}{l}N \\
L \\
N \\
N \\
N\end{array}$ & $\begin{array}{l}50 \\
70 \\
70 \\
70 \\
L\end{array}$ & $\begin{array}{l}500 \\
700 \\
700 \\
200 \\
100\end{array}$ & $\begin{array}{l}N \\
N \\
N \\
L \\
N\end{array}$ \\
\hline $\begin{array}{r}596 \\
597 \\
5163 \\
5165 \\
5166 A\end{array}$ & $\begin{array}{r}700 \\
30 \\
200 \\
1,000 \\
30\end{array}$ & $\begin{array}{l}N \\
N \\
N \\
N \\
1\end{array}$ & $\begin{array}{l}700 \\
500 \\
200 \\
150 \\
700\end{array}$ & $\begin{array}{r}N \\
10 \\
N \\
N \\
N\end{array}$ & $\begin{array}{l}N \\
N \\
N \\
N \\
N\end{array}$ & $\begin{array}{r}7 \\
10 \\
7 \\
20 \\
\mathrm{~N}\end{array}$ & $\begin{array}{l}50 \\
10 \\
15 \\
20 \\
20\end{array}$ & $\begin{array}{r}5 \\
5 \\
N \\
15 \\
10\end{array}$ & $\begin{array}{l}N \\
N \\
L \\
L \\
L\end{array}$ & $\begin{array}{r}10 \\
200 \\
20 \\
20 \\
500\end{array}$ & $\begin{array}{r}500 \\
1,500 \\
300 \\
100 \\
700\end{array}$ & $\begin{array}{l}N \\
N \\
N \\
N \\
N\end{array}$ \\
\hline$S 1668$ & 50 & $L$ & 700 & $N$ & $\mathrm{~N}$ & $N$ & L & $N$ & $L$ & 50 & 1,000 & $\mathbf{N}$ \\
\hline
\end{tabular}


altered areas, eastern contiguous area.

limit of measurement. Number in parentheses below element symbol is the usual lower limit of determination. Also of material sampled, were Fe (.05), Mg (0.02), Ca (0.05), Ti (0.002), As (200), Au (10), Be (1), Cr (10), :

\begin{tabular}{|c|c|c|c|c|c|c|c|c|c|}
\hline \multirow[b]{2}{*}{ Sample } & \multicolumn{8}{|c|}{$\begin{array}{c}\text { Chemical analyses } \\
(\mathrm{ppm})\end{array}$} & \multirow[b]{2}{*}{ Sample description } \\
\hline & $\begin{array}{l}\mathrm{Au} \\
(.05) \\
\end{array}$ & $\begin{array}{l}\mathrm{Hg} \\
(.02) \\
\end{array}$ & $\begin{array}{l}\mathrm{Cu} \\
(5) \\
\end{array}$ & $\begin{array}{l}\mathrm{Pb} \\
(5)\end{array}$ & $\begin{array}{l}\mathrm{Zn} \\
(5) \\
\end{array}$ & $\begin{array}{c}\text { As } \\
(10) \\
\end{array}$ & $\begin{array}{c}\mathrm{Sb} \\
(.5) \\
\end{array}$ & $\begin{array}{l}\mathrm{Te} \\
(.5)\end{array}$ & \\
\hline \multicolumn{10}{|c|}{ Cimarron altered area--Continued } \\
\hline $\begin{array}{l}\$ 85 A \\
585 B \\
585 C \\
5850 \\
585 E\end{array}$ & $\begin{array}{l}\mathrm{N} \\
\mathrm{N} \\
\mathrm{N} \\
\mathrm{N} \\
\mathrm{N}\end{array}$ & $\begin{array}{l}1.2 \\
.35 \\
\mathrm{~N} \\
.65\end{array}$ & $\begin{array}{l}5 \\
10 \\
45 \\
55 \\
20\end{array}$ & $\begin{array}{r}40 \\
15 \\
10 \\
5 \\
20\end{array}$ & $\begin{array}{l}45 \\
80 \\
80 \\
80 \\
20\end{array}$ & $\begin{array}{r}160 \\
N \\
10 \\
10 \\
700\end{array}$ & $1_{1}^{1} \cdot 5$ & $\begin{array}{l}2 \\
\mathrm{~L} \\
\mathrm{~N} \\
\mathrm{~N} \\
.5\end{array}$ & $\begin{array}{l}\text { Altered monzonite dike; pyrite. } \\
\text { Altered andesite breccia; pyrite. } \\
\text { Altered andesite breccia. } \\
\text { Propylitized andesite breccia. } \\
\text { Altered monzonite; pyrite. }\end{array}$ \\
\hline $\begin{array}{l}\$ 85 F \\
585 G \\
\$ 85 H \\
\$ 851 \\
S 85 J\end{array}$ & $\begin{array}{l}\mathrm{N} \\
\mathrm{N} \\
\mathrm{N} \\
\mathrm{N} \\
\mathrm{N}\end{array}$ & $\begin{array}{l}.04 \\
.04 \\
.04\end{array}$ & $\begin{array}{l}30 \\
30 \\
10 \\
30 \\
50\end{array}$ & $\begin{array}{l}60 \\
60 \\
65 \\
35 \\
30\end{array}$ & $\begin{array}{l}45 \\
45 \\
35 \\
65 \\
70\end{array}$ & $\begin{array}{r}N \\
20 \\
10 \\
10 \\
60\end{array}$ & $\begin{array}{l}3 \\
2 \\
2 \\
1 \\
1\end{array}$ & $\begin{array}{l}1 \\
2 \\
1 \\
1 \\
1\end{array}$ & $\begin{array}{l}\text { Fines from altered monzonite talus. } \\
\text { Do. } \\
\text { Do. } \\
\text { Do. } \\
\text { Do. }\end{array}$ \\
\hline $\begin{array}{l}S 86 A \\
S 86 B \\
S 86 C \\
5860 \\
S 86 E\end{array}$ & $\begin{array}{l}\mathrm{N} \\
\mathrm{N} \\
\mathrm{N} \\
\mathrm{N} \\
\mathrm{N}\end{array}$ & $\begin{array}{l}.60 \\
.90 \\
.14 \\
.40 \\
.70\end{array}$ & $\begin{array}{r}35 \\
10 \\
5 \\
5 \\
10\end{array}$ & $\begin{array}{l}5 \\
15 \\
25 \\
10 \\
75\end{array}$ & $\begin{array}{r}65 \\
160 \\
190 \\
65 \\
90\end{array}$ & $\begin{array}{l}10 \\
N \\
160 \\
160 \\
10\end{array}$ & $i_{1}^{.5}$ & $\begin{array}{l}\mathrm{L} \\
\mathrm{L} \\
\mathrm{N} \\
\mathrm{L} \\
\mathrm{I}\end{array}$ & $\begin{array}{l}\text { Altered monzonite dike; pyrite. } \\
\text { Altered andesite breccia; pyrite. } \\
\text { Monzonite dike; pyrite. } \\
\text { Altered monzonite dike; pyrite. } \\
\text { Altered monzonite dike; limonite. }\end{array}$ \\
\hline $\begin{array}{r}\$ 86 F \\
\$ 86 G \\
\$ 86 H \\
\$ 861 \\
S 170 A\end{array}$ & $\begin{array}{l}\mathrm{N} \\
\mathrm{N} \\
\mathrm{N} \\
\mathrm{N} \\
\mathrm{N}\end{array}$ & $\begin{array}{l}.12 \\
N \\
.90 \\
.20\end{array}$ & $\begin{array}{r}35 \\
5 \\
25 \\
25 \\
25\end{array}$ & $\begin{array}{r}75 \\
10 \\
600 \\
35 \\
20\end{array}$ & $\begin{array}{r}95 \\
80 \\
750 \\
90 \\
90\end{array}$ & $\begin{array}{r}L \\
N \\
60 \\
1,600 \\
L\end{array}$ & $\begin{array}{l}1 \\
2 \\
3 \\
1 \\
\text { L }\end{array}$ & $\begin{array}{l}3 \\
N \\
3 \\
L \\
L\end{array}$ & $\begin{array}{l}\text { Altered andesite breccia. } \\
\text { Monzonite dike. } \\
\text { Altered andesite breccia; limonite. } \\
\text { Altered monzonite dike; pyrite. } \\
\text { Altered contact; monzonite intrusive. }\end{array}$ \\
\hline $\begin{array}{r}\$ 1708 \\
\$ 171 \\
\$ 172 \\
\$ 173 \\
\$ 174\end{array}$ & $\begin{array}{l}\mathrm{N} \\
\mathrm{N} \\
\mathrm{N} \\
\mathrm{N} \\
\mathrm{N}\end{array}$ & $\begin{array}{l}\mathrm{N} \\
\mathrm{N} \\
.95 \\
.95 \\
.04\end{array}$ & $\begin{array}{l}25 \\
15 \\
15 \\
10 \\
15\end{array}$ & $\begin{array}{r}35 \\
5 \\
5 \\
10 \\
10\end{array}$ & $\begin{array}{r}65 \\
30 \\
15 \\
N \\
30\end{array}$ & $\begin{array}{r}20 \\
N \\
N \\
N \\
10\end{array}$ & $\begin{array}{l}\mathrm{L}_{.5}^{.5} \\
\mathrm{~L}_{.5}\end{array}$ & $\begin{array}{l}\mathrm{L} \\
1 \\
2 \\
.5 \\
.5\end{array}$ & $\begin{array}{l}\text { Do. } \\
\text { Altered monzonite; pyrite. } \\
\text { Do. } \\
\text { Do. } \\
\text { Soft argillized monzonite. }\end{array}$ \\
\hline$\$ 175$ & N & .92 & 5 & $\mathbf{L}$ & N & N & L & $L$ & Altered monzonite; pyrite. \\
\hline
\end{tabular}

\begin{tabular}{|c|c|c|c|c|c|c|c|c|c|}
\hline \multicolumn{10}{|c|}{ Mat terhorn altered area--Continued } \\
\hline $\begin{array}{l}S 89 A \\
S 89 B \\
S 89 C \\
S 89 E \\
S 89 F\end{array}$ & $\begin{array}{l}\mathrm{N} \\
\mathrm{N} \\
\mathrm{N} \\
\mathrm{N} \\
\mathrm{N}\end{array}$ & $\begin{array}{r}0.10 \\
.10 \\
.12 \\
.12 \\
.80\end{array}$ & $\begin{array}{r}25 \\
5 \\
5 \\
20 \\
40\end{array}$ & $\begin{array}{l}20 \\
25 \\
20 \\
60 \\
60\end{array}$ & $\begin{array}{r}50 \\
5 \\
5 \\
150 \\
120\end{array}$ & $\begin{array}{r}40 \\
60 \\
N \\
80 \\
L\end{array}$ & $1_{.5}^{1}$ & $\begin{array}{l}2 \\
2 \\
1.1 \\
2 \\
.5\end{array}$ & $\begin{array}{l}\text { Altered contact, monzonite stock. } \\
\text { Do. } \\
\text { Do. } \\
\text { Argillized monzonite. } \\
\text { Altered monzonite; pyrite. }\end{array}$ \\
\hline $\begin{array}{l}\text { S90B } \\
\text { S91 } \\
\text { S93A } \\
\text { S93B } \\
\text { S93C }\end{array}$ & $\begin{array}{l}N \\
N \\
N \\
N \\
N\end{array}$ & $\begin{array}{l}N \\
2 \\
.16 \\
.12 \\
.18\end{array}$ & $\begin{array}{r}30 \\
5 \\
5 \\
30 \\
40\end{array}$ & $\begin{array}{r}10 \\
270 \\
50 \\
25 \\
25\end{array}$ & $\begin{array}{r}40 \\
N \\
N \\
55 \\
70\end{array}$ & $\begin{array}{l}N \\
L \\
20 \\
40 \\
60\end{array}$ & $\begin{array}{l}1 \\
1 \\
.5 \\
.5 \\
.5\end{array}$ & ${ }_{1}^{N} \cdot 5$ & $\begin{array}{l}\text { Propylitized monzonite. } \\
\text { Silicified and pyritized monzonite. } \\
\text { Altered fines from monzonite talus. } \\
\text { Do. } \\
\text { Do. }\end{array}$ \\
\hline $\begin{array}{l}\text { S930 } \\
\text { S93E } \\
\text { S93F } \\
\text { S94 } \\
\text { \$95 }\end{array}$ & $\begin{array}{l}\mathrm{N} \\
\mathrm{N} \\
\mathrm{N} \\
\mathrm{N} \\
\mathrm{N}\end{array}$ & $\begin{array}{l}.12 \\
.14 \\
.20 \\
.12\end{array}$ & $\begin{array}{l}35 \\
35 \\
30 \\
10 \\
20\end{array}$ & $\begin{array}{r}30 \\
55 \\
30 \\
75 \\
5\end{array}$ & $\begin{array}{l}45 \\
60 \\
45 \\
15 \\
50\end{array}$ & $\begin{array}{r}N \\
20 \\
20 \\
120 \\
20\end{array}$ & $\begin{array}{l}1 \\
1 \\
2 \\
2 \\
1\end{array}$ & $\begin{array}{l}.5 \\
. .5 \\
2 \\
1\end{array}$ & $\begin{array}{l}\text { Do. } \\
\text { Do. } \\
\text { Do. } \\
\text { Altered andesite breccia. } \\
\text { Propylitized monzonite; pyrite. }\end{array}$ \\
\hline $\begin{array}{r}\$ 96 \\
\$ 97 \\
\$ 163 \\
\$ 165 \\
\$ 166 A\end{array}$ & $\begin{array}{l}\mathrm{N} \\
\mathrm{N} \\
\mathrm{N} \\
\mathrm{N} \\
.10\end{array}$ & $L_{.10}^{.40}$ & $\begin{array}{l}75 \\
30 \\
55 \\
35 \\
30\end{array}$ & $\begin{array}{r}10 \\
300 \\
20 \\
25 \\
900\end{array}$ & $\begin{array}{l}75 \\
45 \\
90 \\
20\end{array}$ & $\begin{array}{l}1,200 \\
600 \\
10 \\
40 \\
80\end{array}$ & $2_{4}^{.5}$ & $\begin{array}{l}N \\
1 \\
L \\
N \\
2\end{array}$ & $\begin{array}{l}\text { Silicified monzonite; pyrite. } \\
\text { Do. } \\
\text { Altered andesite. } \\
\text { Do. } \\
\text { Do. }\end{array}$ \\
\hline S166B & N & .2 & 5 & 40 & $\mathrm{~N}$ & 20 & .5 & 1 & Do. \\
\hline
\end{tabular}


TABLE 6.-Analyses of rock samples from altered

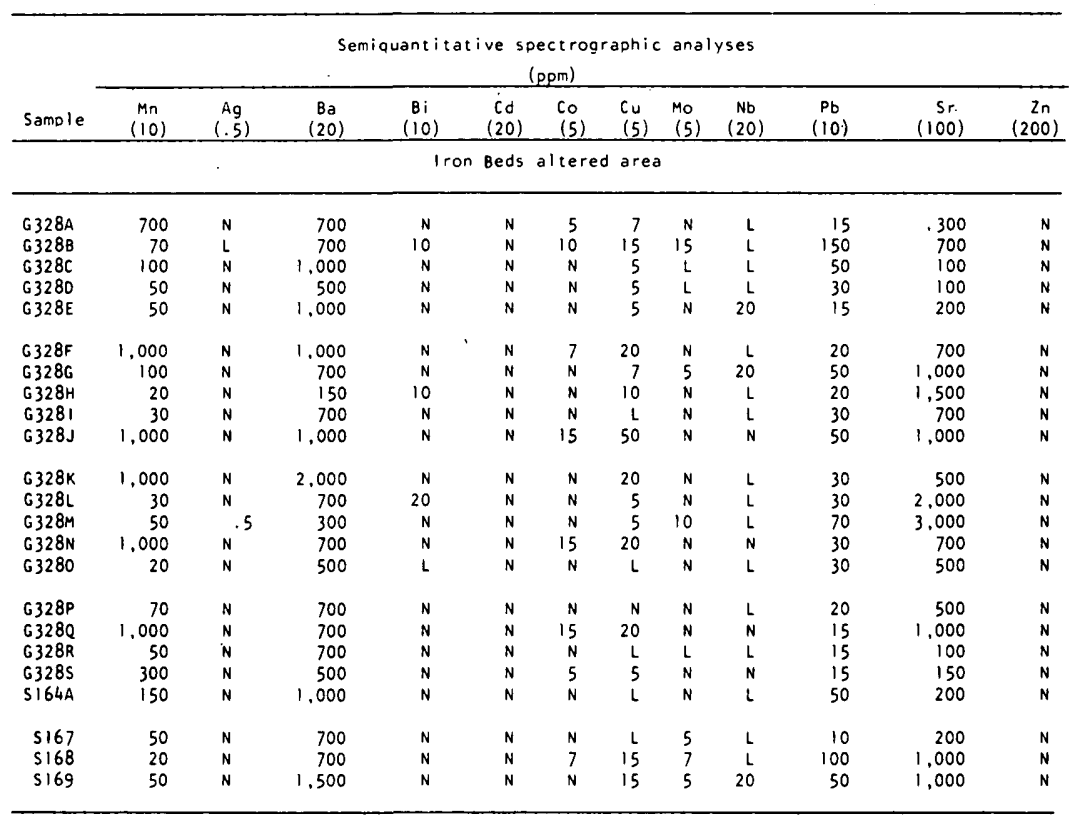


CONTIGUOUS AREAS, UNCOMPAHGRE PRIMITIVE AREA, COLO. E99

areas, e astern contiguous area - Continued

\begin{tabular}{|c|c|c|c|c|c|c|c|c|c|}
\hline \multirow[b]{2}{*}{ Sample } & \multicolumn{8}{|c|}{$\begin{array}{c}\text { Chemical analyses } \\
(\mathrm{ppm})\end{array}$} & \multirow[b]{2}{*}{ Sample description } \\
\hline & $\begin{array}{l}\mathrm{Au} \\
(.05)\end{array}$ & $\stackrel{\mathrm{Hg}}{(.02)}$ & $\begin{array}{l}\mathrm{Cu} \\
(5)\end{array}$ & $\begin{array}{l}\mathrm{Pb} \\
(5)\end{array}$ & $\begin{array}{l}2 n \\
(5)\end{array}$ & $\begin{array}{c}\text { As } \\
(10)\end{array}$ & $\begin{array}{c}\text { Sb } \\
(.5) \\
\end{array}$ & $\begin{array}{l}T e \\
(.5) \\
\end{array}$ & \\
\hline \multicolumn{10}{|c|}{ Iron Beds altered area--Continued } \\
\hline $\begin{array}{l}\text { G328A } \\
6328 B \\
\text { G328C } \\
\text { G328D } \\
\text { G328E }\end{array}$ & $\begin{array}{l}\mathrm{N} \\
\mathrm{N} \\
\mathrm{N} \\
\mathrm{N} \\
\mathrm{N}\end{array}$ & $\begin{array}{l}\mathrm{N} \\
\mathrm{N} \\
.02 \\
.24\end{array}$ & $\begin{array}{r}10 \\
10 \\
10 \\
L \\
L\end{array}$ & $\begin{array}{r}5 \\
10 \\
25 \\
15 \\
5\end{array}$ & $\begin{array}{r}25 \\
N \\
35 \\
L \\
N\end{array}$ & $\begin{array}{r}N \\
10 \\
10 \\
10 \\
1\end{array}$ & $L^{L} L^{-5}$ & $\mathrm{~N}^{\mathrm{N}} \cdot .5$ & $\begin{array}{l}\text { Slightly altered Fish Canyon Tuff. } \\
\text { Highly altered Sediments. } \\
\text { Highly altered Crystal Lake Tuff. } \\
\text { Slightly altered Carpenter Ridge Tuff. } \\
\text { Highly altered lava flow. }\end{array}$ \\
\hline $\begin{array}{l}\text { G328F } \\
\text { G328G } \\
\text { G328H } \\
63281 \\
\text { G328J }\end{array}$ & $\begin{array}{l}N \\
N \\
N \\
N \\
N\end{array}$ & $\begin{array}{l}.02 \\
.08 \\
.04 \\
.02 \\
.60\end{array}$ & $\begin{array}{r}25 \\
5 \\
L \\
L \\
40\end{array}$ & $\begin{array}{r}15 \\
25 \\
L \\
10 \\
20\end{array}$ & $\begin{array}{r}40 \\
\mathrm{~L} \\
\mathrm{~N} \\
\mathrm{~N} \\
75\end{array}$ & $\begin{array}{l}N \\
10 \\
10 \\
20 \\
10\end{array}$ & $\begin{array}{l}\mathrm{L} \\
2 \\
\mathrm{~L} \\
\mathrm{l} \\
\mathrm{L}\end{array}$ & $2^{4} \cdot 5$ & $\begin{array}{l}\text { Unaltered lava flow. } \\
\text { Altered fines in pit on lava flow. } \\
\text { Highly altered lava flow. } \\
\text { Altered fines in pit on lava flow. } \\
\text { Unaltered lava flow. }\end{array}$ \\
\hline $\begin{array}{l}\text { G328K } \\
\text { G328L } \\
\text { G328M } \\
\text { G328N } \\
\text { G3280 }\end{array}$ & $\begin{array}{l}\mathbf{N} \\
\mathbf{N} \\
\mathrm{N} \\
\mathbf{N} \\
\mathbf{N}\end{array}$ & $\begin{array}{l}.20 \\
.06 \\
.70 \\
.08\end{array}$ & $\begin{array}{r}30 \\
L \\
5 \\
40 \\
L\end{array}$ & $\begin{array}{r}15 \\
10 \\
15 \\
5 \\
30\end{array}$ & $\begin{array}{r}20 \\
N \\
N \\
35 \\
N\end{array}$ & $\begin{array}{r}10 \\
10 \\
20 \\
\mathrm{~N} \\
\mathrm{~L}\end{array}$ & $\begin{array}{l}L \\
1 \\
5 \\
L \\
L\end{array}$ & $\begin{array}{l}2 \\
L \\
3 \\
N \\
L\end{array}$ & $\begin{array}{l}\text { Altered lava flow. } \\
\text { Altered tuff. } \\
\text { Narrow altered zone in lava flow. } \\
\text { Unaltered lava flow. } \\
\text { Highly altered Carpenter Ridge Tuff. }\end{array}$ \\
\hline $\begin{array}{l}\text { G328P } \\
\text { G328Q } \\
\text { G328R } \\
\text { G328S } \\
\text { S164A }\end{array}$ & $\begin{array}{l}\mathbf{N} \\
\mathbf{N} \\
\mathbf{N} \\
\mathbf{N} \\
\mathbf{N}\end{array}$ & $\begin{array}{l}.16 \\
.10 \\
.20\end{array}$ & $\begin{array}{r}5 \\
40 \\
5 \\
5 \\
5\end{array}$ & $\begin{array}{r}10 \\
5 \\
10 \\
5 \\
15\end{array}$ & $\begin{array}{r}N \\
30 \\
5 \\
L \\
5\end{array}$ & $\begin{array}{r}120 \\
1 \\
10 \\
10 \\
20\end{array}$ & $\begin{array}{l}L^{.5} \\
L\end{array}$ & $\begin{array}{l}\mathbf{I} \\
\mathbf{N} \\
\mathbf{N} \\
\mathbf{N} \\
\mathrm{L}\end{array}$ & $\begin{array}{l}\text { Altered Carpenter Ridge Tuff. } \\
\text { Altered vitrophyre Crystal Lake Tuff. } \\
\text { Highty altered Fish Canyon Tuff. } \\
\text { Unaltered sediments. } \\
\text { Highly altered Crystal Lake Tuff. }\end{array}$ \\
\hline $\begin{array}{l}\$ 167 \\
\$ 168 \\
\$ 169\end{array}$ & $\begin{array}{l}\mathbf{N} \\
\mathbf{N} \\
\mathbf{N}\end{array}$ & $\begin{array}{l}.68 \\
.90\end{array}$ & $\begin{array}{r}1 \\
10 \\
5\end{array}$ & $\begin{array}{r}10 \\
20 \\
5\end{array}$ & $\begin{array}{r}N \\
N \\
25\end{array}$ & $\underset{N}{20}$ & $\begin{array}{l}L \\
L\end{array}$ & $\begin{array}{l}\text { N } \\
\text { L } \\
\text { L }\end{array}$ & $\begin{array}{l}\text { Highly altered lava flow. } \\
\text { Highly altered monzonite dike; pyrite. } \\
\text { Altered Fish Canyon Tuff; pyrite. }\end{array}$ \\
\hline
\end{tabular}


TABLE 7.-Analyses of rhyolite intrusive rocks

[See plate $2 A$ for sample localities. ppm, parts per million, N, not detected, L, detected but below lower of determination. Also looked for in spectrographic analyses, and either not found or found in amounts B (10), Bi (10), Cd (20), Co (5), Cr (10), La (20), Ni (5), Sb (100), Sc (5), W (50), Zn (200), and Zr (10)]

\begin{tabular}{|c|c|c|c|c|c|c|c|c|c|c|c|c|}
\hline \multirow[b]{2}{*}{ Sample } & \multicolumn{12}{|c|}{$\begin{aligned} \text { Semiquantitative spectrographic analyses } \\
(\mathrm{ppm})\end{aligned}$} \\
\hline & $\begin{array}{c}M n \\
(10)\end{array}$ & $\begin{array}{c}\mathrm{Ag} \\
(.5)\end{array}$ & $\begin{array}{c}B a \\
(20) \\
\end{array}$ & $\begin{array}{l}\text { Be } \\
\text { (I) }\end{array}$ & $\begin{array}{l}\mathrm{Cu} \\
\text { (5) }\end{array}$ & $\begin{array}{c}\text { Mo } \\
(5) \\
\end{array}$ & $\begin{array}{c}\mathrm{Nb} \\
(20) \\
\end{array}$ & $\begin{array}{c}\mathrm{Pb} \\
(10)\end{array}$ & $\begin{array}{c}\text { Sn } \\
(10)\end{array}$ & $\begin{array}{c}S r \\
(100)\end{array}$ & $\begin{array}{c}v \\
(10) \\
\end{array}$ & $\begin{array}{r}Y \\
(10) \\
\end{array}$ \\
\hline \multicolumn{13}{|c|}{$\begin{array}{c}\text { PLUG ALONG EAST FORK OF NELLIE CREEK } \\
\text { Intrusive rock }\end{array}$} \\
\hline $\begin{array}{l}5470 \\
547 F \\
598 A \\
598 B \\
598 C\end{array}$ & $\begin{array}{r}1,000 \\
1,000 \\
700 \\
700 \\
700\end{array}$ & $\begin{array}{l}N \\
N \\
N \\
N \\
N\end{array}$ & $\begin{array}{r}70 \\
200 \\
200 \\
100 \\
100\end{array}$ & $\begin{array}{r}15 \\
20 \\
7 \\
7 \\
10\end{array}$ & $\begin{array}{l}N \\
L \\
L \\
L \\
L\end{array}$ & $\begin{array}{r}N \\
15 \\
N \\
N \\
N\end{array}$ & $\begin{array}{l}50 \\
30 \\
30 \\
20 \\
30\end{array}$ & $\begin{array}{l}30 \\
50 \\
30 \\
30 \\
30\end{array}$ & $\begin{array}{l}N \\
N \\
N \\
N \\
N\end{array}$ & $\begin{array}{r}N \\
L \\
100 \\
N \\
L\end{array}$ & $\begin{array}{l}N \\
N \\
N \\
N \\
N\end{array}$ & $\begin{array}{r}N \\
L \\
15 \\
L \\
10\end{array}$ \\
\hline $\begin{array}{r}\$ 103 \\
\$ 104 \\
\$ 105 \\
\$ 106 A \\
\$ 106 B\end{array}$ & $\begin{array}{r}1,000 \\
1,500 \\
1,500 \\
700 \\
700\end{array}$ & $\begin{array}{l}N \\
N \\
N \\
N \\
N\end{array}$ & $\begin{array}{l}150 \\
150 \\
150 \\
150 \\
150\end{array}$ & $\begin{array}{r}7 \\
10 \\
10 \\
10 \\
7\end{array}$ & $\begin{array}{r}L \\
10 \\
5 \\
L \\
5\end{array}$ & $\begin{array}{l}N \\
N \\
N \\
5 \\
7\end{array}$ & $\begin{array}{l}30 \\
20 \\
30 \\
30 \\
30\end{array}$ & $\begin{array}{l}70 \\
50 \\
50 \\
50 \\
50\end{array}$ & $\begin{array}{l}\mathbf{N} \\
\mathbf{N} \\
\mathbf{N} \\
\mathbf{N} \\
\mathbf{N}\end{array}$ & $\begin{array}{r}L \\
N \\
L \\
N \\
100\end{array}$ & $\begin{array}{r}\mathrm{N} \\
\mathrm{N} \\
\mathrm{N} \\
\mathrm{N} \\
10\end{array}$ & $\begin{array}{r}15 \\
N \\
15 \\
10 \\
10\end{array}$ \\
\hline $\begin{array}{r}S 110 A \\
S 110 B \\
S 112 A \\
5113 \\
147\end{array}$ & $\begin{array}{r}1,500 \\
700 \\
700 \\
700 \\
-\end{array}$ & $\begin{array}{l}\mathrm{N} \\
\mathrm{N} \\
\mathrm{N} \\
\mathrm{N} \\
\mathrm{N}\end{array}$ & $\begin{array}{l}500 \\
100 \\
150 \\
100 \\
520\end{array}$ & $\begin{array}{r}20 \\
10 \\
15 \\
7 \\
19\end{array}$ & $\begin{array}{l}5 \\
5 \\
L \\
L \\
2\end{array}$ & $\begin{array}{r}15 \\
5 \\
N \\
7 \\
8\end{array}$ & $\begin{array}{l}70 \\
30 \\
50 \\
30 \\
80\end{array}$ & $\begin{array}{l}50 \\
30 \\
50 \\
50 \\
40\end{array}$ & $\begin{array}{l}\mathbf{N} \\
\mathbf{N} \\
\mathbf{N} \\
\mathbf{N} \\
\mathbf{N}\end{array}$ & $\begin{array}{r}300 \\
N \\
L \\
N \\
160\end{array}$ & $\begin{array}{r}\mathrm{N} \\
\mathrm{N} \\
\mathrm{N} \\
\mathrm{N} \\
<10\end{array}$ & $\begin{array}{r}10 \\
\mathrm{~L} \\
\mathrm{~L} \\
\mathrm{~L} \\
<20\end{array}$ \\
\hline
\end{tabular}

Wall rock

\begin{tabular}{|c|c|c|c|c|c|c|c|c|c|c|c|c|}
\hline $\begin{array}{r}547 \mathrm{~A} \\
547 \mathrm{~B} \\
547 \mathrm{C} \\
547 \mathrm{E} \\
5106 \mathrm{C}\end{array}$ & $\begin{array}{r}>5,000 \\
>5,000 \\
>5,000 \\
200 \\
1,500\end{array}$ & $\begin{array}{l}\mathbf{N} \\
\mathbf{N} \\
\mathbf{N} \\
\mathbf{N} \\
\mathbf{N}\end{array}$ & $\begin{array}{r}700 \\
1,000 \\
700 \\
1,000 \\
700\end{array}$ & $\begin{array}{l}1.5 \\
1.5 \\
3 \\
2 \\
2\end{array}$ & $\begin{array}{r}20 \\
50 \\
20 \\
L \\
15\end{array}$ & $\begin{array}{l}\mathbf{N} \\
N \\
N \\
N \\
N\end{array}$ & $\begin{array}{r}N \\
N \\
N \\
N \\
20\end{array}$ & $\begin{array}{l}20 \\
20 \\
30 \\
70 \\
50\end{array}$ & $\begin{array}{l}\mathbf{N} \\
\mathbf{N} \\
\mathbf{N} \\
\mathbf{N} \\
\mathbf{N}\end{array}$ & $\begin{array}{l}700 \\
500 \\
500 \\
300 \\
150\end{array}$ & $\begin{array}{r}70 \\
100 \\
70 \\
15 \\
70\end{array}$ & $\begin{array}{r}150 \\
100 \\
70 \\
20 \\
20\end{array}$ \\
\hline $\begin{array}{r}\$ 107 \\
5108 \\
\$ 111 \\
S 112 B \\
S 114 A\end{array}$ & $\begin{array}{r}500 \\
500 \\
2,000 \\
1,500 \\
200\end{array}$ & $\begin{array}{l}\mathrm{N} \\
\mathrm{N} \\
\mathrm{N} \\
\mathrm{N} \\
\mathrm{N}\end{array}$ & $\begin{array}{r}700 \\
1,500 \\
1,000 \\
1,000 \\
500\end{array}$ & $\begin{array}{l}L \\
L \\
3 \\
L \\
L\end{array}$ & $\begin{array}{r}5 \\
10 \\
20 \\
20 \\
L\end{array}$ & $\begin{array}{l}L \\
N \\
N \\
N \\
N\end{array}$ & $\begin{array}{l}L \\
L \\
L \\
N \\
L\end{array}$ & $\begin{array}{l}30 \\
70 \\
30 \\
30 \\
20\end{array}$ & $\begin{array}{l}\mathbf{N} \\
\mathbf{N} \\
\mathbf{N} \\
\mathbf{N} \\
\mathbf{N}\end{array}$ & $\begin{array}{r}100 \\
200 \\
1,000 \\
700 \\
100\end{array}$ & $\begin{array}{r}20 \\
20 \\
150 \\
300 \\
20\end{array}$ & $\begin{array}{l}20 \\
20 \\
30 \\
20 \\
20\end{array}$ \\
\hline $\begin{array}{l}S 1148 \\
S 114 C \\
S 1140\end{array}$ & $\begin{array}{r}300 \\
1,000 \\
1,000\end{array}$ & $\begin{array}{l}\mathbf{N} \\
\mathbf{N} \\
\mathbf{N}\end{array}$ & $\begin{array}{l}700 \\
300 \\
700\end{array}$ & $\begin{array}{l}1 \\
3 \\
1.5\end{array}$ & $\begin{array}{l}\mathbf{L} \\
\mathbf{L}\end{array}$ & $\begin{array}{l}\mathrm{N} \\
\mathrm{N} \\
\mathrm{N}\end{array}$ & $\begin{array}{l}\mathbf{L} \\
\mathbf{L} \\
\mathbf{L}\end{array}$ & $\begin{array}{l}20 \\
30 \\
30\end{array}$ & $\begin{array}{l}\mathrm{N} \\
\mathrm{N} \\
\mathrm{N}\end{array}$ & $\begin{array}{l}100 \\
200 \\
200\end{array}$ & $\begin{array}{l}15 \\
15 \\
20\end{array}$ & $\begin{array}{l}30 \\
30 \\
15\end{array}$ \\
\hline
\end{tabular}




\section{and associated wallrocks, eastern contiguous area}

limit of measurement, ..., not analyzed. Number in parentheses below element symbol is the usual lower limit normal for the type of material sampled, were, $\mathrm{Fe}(0.05), \mathrm{Mg}(0.02), \mathrm{Ca}(0.05)$, $\mathrm{Ti}(0.002)$, As (200), Au (10),

\begin{tabular}{|c|c|c|c|c|c|c|c|c|c|c|}
\hline \multirow[b]{2}{*}{ Sample } & \multicolumn{8}{|c|}{$\begin{array}{c}\text { Chemical analyses } \\
(\mathrm{ppm})\end{array}$} & \multirow{2}{*}{$\begin{array}{l}\text { Instrumental } \\
\text { radioactivity } \\
\text { reading }\end{array}$} & \multirow[b]{2}{*}{ Sample description } \\
\hline & $\begin{array}{c}\mathrm{Au} \\
(.05)\end{array}$ & $\stackrel{\mathrm{Hg}}{(.02)}$ & $\begin{array}{l}\mathrm{Cu} \\
(5)\end{array}$ & $\begin{array}{l}\mathrm{Pb} \\
(5)\end{array}$ & $\begin{array}{l}2 n \\
(5)\end{array}$ & $\begin{array}{l}\text { As } \\
(5)\end{array}$ & $\begin{array}{l}S b \\
(.5)\end{array}$ & $\underset{(50)}{F}$ & & \\
\hline \multicolumn{11}{|c|}{$\begin{array}{l}\text { PLUG ALONG EAST FORK OF NELLIE CREEK--Cont inued } \\
\text { Intrusive rock--Continued }\end{array}$} \\
\hline $\begin{array}{l}\$ 470 \\
\$ 47 F \\
598 A \\
\$ 98 B \\
S 98 C\end{array}$ & $\begin{array}{l}N \\
N \\
N \\
N \\
N\end{array}$ & $\begin{array}{c}N \\
.02 \\
--- \\
---\end{array}$ & $\begin{array}{r}N \\
L \\
--- \\
---\end{array}$ & $\begin{array}{r}10 \\
5 \\
--2 \\
-0-\end{array}$ & $\begin{array}{c}5 \\
5 \\
--- \\
-- \\
\cdots\end{array}$ & $\begin{array}{c}N \\
N \\
---\end{array}$ & $\begin{array}{l}\mathrm{L} \\
.5 \\
-. . \\
-.-\end{array}$ & $\begin{array}{l}800 \\
700 \\
270 \\
700 \\
900\end{array}$ & $\begin{array}{l}\cdots \\
0.15-0.575 \\
.15-.600 \\
.15-.575\end{array}$ & $\begin{array}{l}\text { Devitrified rhyolite. Topaz. } \\
\text { Marginal vitrophyre. } \\
\text { Devitrified rhyolite. } \\
\text { Do. } \\
\text { Do. }\end{array}$ \\
\hline $\begin{array}{r}\$ 103 \\
5104 \\
S 105 \\
S 106 A \\
S 106 B\end{array}$ & $\begin{array}{c}N \\
N \\
N \\
N \\
---\end{array}$ & $\begin{array}{l}-- \\
\cdots \\
\cdots- \\
--\end{array}$ & $\begin{array}{l}\cdots \\
\cdots- \\
\cdots \\
\cdots-\end{array}$ & $\begin{array}{l}\cdots \\
\cdots- \\
\cdots-\end{array}$ & $\begin{array}{l}--- \\
--- \\
--- \\
--\end{array}$ & $\begin{array}{l}--- \\
--- \\
--- \\
--\end{array}$ & $\begin{array}{l}\cdots- \\
--- \\
--- \\
---\end{array}$ & $\begin{array}{r}375 \\
N \\
L \\
N \\
L\end{array}$ & $\begin{array}{l}.15-.570 \\
.15-.575 \\
.15-.450 \\
.15-.430 \\
.15-.540\end{array}$ & $\begin{array}{l}\text { Do. } \\
\text { Do. } \\
\text { Porous devitrified rhyolite. } \\
\text { Do. } \\
\text { Marginal vitrophyre. }\end{array}$ \\
\hline $\begin{array}{r}S 110 A \\
S 1108 \\
S 112 A \\
S 113 \\
147\end{array}$ & $\begin{array}{c}n \\
N \\
N \\
N--\end{array}$ & $\begin{array}{l}\cdots \\
\cdots- \\
--- \\
--\end{array}$ & $\begin{array}{l}--- \\
--- \\
\cdots- \\
---\end{array}$ & $\begin{array}{l}--- \\
--- \\
--- \\
---\end{array}$ & $\begin{array}{l}--- \\
--- \\
--- \\
--\end{array}$ & $\begin{array}{l}--- \\
--- \\
--- \\
---\end{array}$ & $\begin{array}{l}--- \\
--- \\
--- \\
---\end{array}$ & $\begin{array}{r}80 \\
N \\
300 \\
N\end{array}$ & $\begin{array}{l}.15-.660 \\
.15-.585 \\
.15-.600 \\
.15-.600 \\
=-\end{array}$ & $\begin{array}{l}\text { Do } \\
\text { Devitrified rhyolite. } \\
\text { Do. } \\
\text { Do. } \\
\text { Marginal vitrophyre. }\end{array}$ \\
\hline \multicolumn{11}{|c|}{ Wall rock--Cont i nued } \\
\hline $\begin{array}{r}\$ 47 A \\
\$ 47 B \\
S 47 C \\
S 47 E \\
S 106 C\end{array}$ & $\begin{array}{l}0.05 \\
.1 \\
.05 \\
. .-\end{array}$ & $\begin{array}{l}0.02 \\
.02 \\
\mathrm{~L} \\
-.\end{array}$ & $\begin{array}{r}35 \\
60 \\
30 \\
\quad L \\
-\end{array}$ & $\begin{array}{r}10 \\
95 \\
30 \\
10 \\
---\end{array}$ & $\begin{array}{r}40 \\
45 \\
75 \\
L \\
-\cdots\end{array}$ & $\begin{array}{c}N \\
L \\
L \\
-N\end{array}$ & $\begin{array}{l}0.5 \\
L \\
L \\
.5 \\
-.-\end{array}$ & $\begin{array}{r}80 \\
90 \\
90 \\
9 \quad 150 \\
170\end{array}$ & $\begin{array}{l}--- \\
--- \\
--- \\
--\end{array}$ & $\begin{array}{l}\text { Carbonate concretion. } \\
\text { Do. } \\
\text { Do. } \\
\text { Crystal- Lake Tuff. Topaz. } \\
\text { Soil near contact. }\end{array}$ \\
\hline $\begin{array}{r}\$ 107 \\
5108 \\
5111 \\
S 112 B \\
5114 A\end{array}$ & $\begin{array}{l}\mathbf{N} \\
\mathbf{N} \\
\mathbf{N} \\
\mathbf{N} \\
\mathbf{N}\end{array}$ & .04 & $\begin{array}{c}--- \\
--- \\
--- \\
-\end{array}$ & $\begin{array}{c}--- \\
-\cdots \\
--- \\
--\end{array}$ & $\begin{array}{l}--- \\
--- \\
---\end{array}$ & $\begin{array}{l}--- \\
--- \\
---\end{array}$ & $\begin{array}{l}--- \\
\cdots- \\
\cdots-\end{array}$ & $\begin{array}{r}N \\
100 \\
80 \\
\cdots\end{array}$ & $\begin{array}{c}0.15-0.375 \\
.15-.340 \\
.15-.425 \\
.15-.380 \\
-. .\end{array}$ & $\begin{array}{l}\text { Crystal Lake Tuff. } \\
\text { Do. } \\
\text { Bentonitic sediments. } \\
\text { Red sediments. } \\
\text { Fault zone. }\end{array}$ \\
\hline $\begin{array}{l}51148 \\
5114 C \\
51140\end{array}$ & $\begin{array}{l}\mathbf{N} \\
\mathbf{N} \\
\mathbf{N}\end{array}$ & $\stackrel{N}{N}$ & $\begin{array}{l}\mathrm{L} \\
\mathrm{L} \\
5\end{array}$ & $\begin{array}{r}5 \\
15 \\
10\end{array}$ & $\begin{array}{l}5 \\
5 \\
5\end{array}$ & $\begin{array}{l}\mathrm{L} \\
\mathrm{L}\end{array}$ & $1^{2} .5$ & 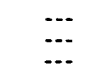 & $\cdots$ & $\begin{array}{l}\text { Do. } \\
\text { Do. } \\
\text { Do. }\end{array}$ \\
\hline
\end{tabular}

See footnote at the end of the table. 
TABLE 7.-Analyses of rhyolite intrusive rocks and

\begin{tabular}{|c|c|c|c|c|c|c|c|c|c|c|c|c|}
\hline \multirow[b]{2}{*}{ Sample } & \multicolumn{12}{|c|}{$\begin{array}{r}\text { Semiquantitative spectrographic analyses } \\
(\mathrm{ppm})\end{array}$} \\
\hline & $\begin{array}{c}M n \\
(10)\end{array}$ & $\stackrel{\mathrm{Ag}}{(.5)}$ & $\begin{array}{c}\text { Ba } \\
(20) \\
\end{array}$ & $\begin{array}{l}\mathrm{Be} \\
(1) \\
\end{array}$ & $\begin{array}{l}\mathrm{Cu} \\
(5)\end{array}$ & $\begin{array}{l}\text { Mo } \\
(5)\end{array}$ & $\begin{array}{c}\mathrm{Nb} \\
(20)\end{array}$ & $\begin{array}{c}\mathrm{Pb} \\
(10) \\
\end{array}$ & $\begin{array}{c}\text { Sn } \\
(10)\end{array}$ & $\begin{array}{c}S r \\
(100) \\
\end{array}$ & $\begin{array}{c}v \\
(10)\end{array}$ & $\begin{array}{c}Y \\
(10) \\
\end{array}$ \\
\hline \multicolumn{13}{|c|}{ SILL BETWEEN E } \\
\hline $\begin{array}{l}S 117 \\
S 118 \\
5119 \\
S 120 \\
S 121\end{array}$ & $\begin{array}{r}1,000 \\
1,000 \\
1,000 \\
700\end{array}$ & \begin{tabular}{c}
$\mathrm{L}$ \\
\hdashline$N$ \\
$N$ \\
$\mathrm{~N}$
\end{tabular} & \begin{tabular}{c}
200 \\
\hdashline- \\
200 \\
500 \\
200
\end{tabular} & $\begin{array}{c}15 \\
10 \\
7 \\
15\end{array}$ & \begin{tabular}{c}
$\mathrm{L}$ \\
\hdashline 10 \\
$\mathrm{~L}$ \\
$\mathrm{~L}$
\end{tabular} & \begin{tabular}{c}
7 \\
\hdashline$N$ \\
$N$ \\
$N$
\end{tabular} & $\begin{array}{r}30 \\
20 \\
50\end{array}$ & $\begin{array}{r}50 \\
-- \\
50 \\
50 \\
50\end{array}$ & $\begin{array}{c}N \\
-- \\
N \\
N \\
N\end{array}$ & $\begin{array}{c}150 \\
-- \\
150 \\
500 \\
500\end{array}$ & $\begin{array}{r}10 \\
10 \\
15 \\
10\end{array}$ & $\begin{array}{r}10 \\
-15 \\
15 \\
10\end{array}$ \\
\hline $\begin{array}{l}S 122 \\
S 123 \\
S 124 \\
S 125 \\
S 126\end{array}$ & $\begin{array}{c}1,000 \\
--- \\
-700 \\
--\end{array}$ & \begin{tabular}{l}
$n$ \\
$n$ \\
\hdashline---
\end{tabular} & $\begin{array}{c}200 \\
-- \\
-- \\
--\end{array}$ & $\begin{array}{l}10 \\
- \\
7 \\
--\end{array}$ & $\begin{array}{c}5 \\
--- \\
-7 \\
---\end{array}$ & $\begin{array}{c}N \\
--- \\
---\end{array}$ & $\begin{array}{r}30 \\
-- \\
- \\
--\end{array}$ & $\begin{array}{r}50 \\
-2 \\
30 \\
--\end{array}$ & $\begin{array}{c}\text { N } \\
--- \\
---\end{array}$ & $\begin{array}{c}100 \\
\cdots \\
\cdots \\
--\end{array}$ & $\begin{array}{r}10 \\
-2 \\
-- \\
20 \\
--\end{array}$ & $\begin{array}{r}10 \\
-- \\
-10 \\
--\end{array}$ \\
\hline $\begin{array}{l}S 127 \\
S 128 \\
S 129 \\
S 130 \\
S 131\end{array}$ & $\begin{array}{c}--- \\
1,000 \\
\ldots \\
700 \\
--\end{array}$ & $\begin{array}{l}--- \\
\mathrm{N} \\
\mathrm{N} \\
-\cdots\end{array}$ & $\begin{array}{c}-- \\
500 \\
-- \\
200 \\
\cdots\end{array}$ & \begin{tabular}{l}
7 \\
\hdashline- \\
--
\end{tabular} & \begin{tabular}{c}
-- \\
5 \\
$L$ \\
\hdashline-
\end{tabular} & $\begin{array}{c}--- \\
N \\
---\end{array}$ & $\begin{array}{r}30 \\
30 \\
--\end{array}$ & $\begin{array}{r}-- \\
30 \\
30 \\
-\end{array}$ & $\begin{array}{c}\cdots \\
\cdots \\
\cdots \\
\cdots\end{array}$ & $\begin{array}{c}-- \\
200 \\
N\end{array}$ & $\begin{array}{r}15 \\
15 \\
15\end{array}$ & $\begin{array}{r}-. \\
15 \\
-2 \\
15 \\
--\end{array}$ \\
\hline $\begin{array}{r}\$ 132 \\
S 133 B \\
\$ 133 C \\
\$ 134 \\
S 135 A\end{array}$ & $\begin{array}{r}--- \\
700 \\
1,000 \\
-.- \\
1,000\end{array}$ & $\begin{array}{l}\mathrm{N} \\
\mathrm{N} \\
---\end{array}$ & $\begin{array}{c}300 \\
300 \\
-- \\
150\end{array}$ & $\begin{array}{l}7 \\
7 \\
10\end{array}$ & \begin{tabular}{c}
.- \\
5 \\
5 \\
\hdashline \\
$L$
\end{tabular} & $\begin{array}{c}N \\
N \\
-- \\
L\end{array}$ & $\begin{array}{r}50 \\
50 \\
-. \\
50\end{array}$ & $\begin{array}{r}-2 \\
30 \\
30 \\
-50\end{array}$ & \begin{tabular}{c}
--- \\
$L$ \\
$N$ \\
\hdashline 10
\end{tabular} & $\begin{array}{l}150 \\
200 \\
100\end{array}$ & $\begin{array}{r}-- \\
20 \\
20 \\
-- \\
L\end{array}$ & $\begin{array}{r}-- \\
20 \\
20 \\
-- \\
10\end{array}$ \\
\hline $\begin{array}{r}S 1358 \\
S 136 \\
S 137 \\
S 138 \\
S 138\end{array}$ & $\begin{array}{c}1,000 \\
\cdots \\
700 \\
\cdots \\
\cdots\end{array}$ & $\begin{array}{l}n \\
n \\
---- \\
---\end{array}$ & $\begin{array}{c}100 \\
-- \\
500 \\
--\end{array}$ & $\begin{array}{c}15 \\
10 \\
\cdots\end{array}$ & \begin{tabular}{c}
$\mathrm{L}$ \\
\hdashline 7 \\
-- \\
---
\end{tabular} & $\begin{array}{c}N \\
-- \\
---\end{array}$ & $\begin{array}{r}30 \\
-- \\
20 \\
---\end{array}$ & $\begin{array}{r}50 \\
50 \\
-- \\
--\end{array}$ & \begin{tabular}{c}
$L$ \\
\hdashline- \\
$-\cdots$
\end{tabular} & $\begin{array}{c}\text { L } \\
500 \\
\ldots-\end{array}$ & $\begin{array}{r}L \\
-- \\
20 \\
---\end{array}$ & $\begin{array}{r}10 \\
-. \\
15 \\
-.-\end{array}$ \\
\hline
\end{tabular}

Wall rock

\begin{tabular}{|c|c|c|c|c|c|c|c|c|c|c|c|c|}
\hline$S 133 A$ & 1,000 & $N$ & 1,000 & N & 20 & N & $\mathbf{N}$ & 30 & N & 1,000 & 200 & 30 \\
\hline 5133 & - & $\cdots$ & - & $\ldots$ & - & -- & - & $\ldots$ & -.- & $\ldots$ & $\ldots$ & $\ldots$ \\
\hline S133 & $=-$ & $\cdots$ & -. & -- & -.. & -- & --- &.-- & -.- & --- & --- & -. \\
\hline 5133 & -- & -. & -- & -- & $\cdots$ & -- & -- & -- & -.. & -- & --- & -. \\
\hline 5134 & $\cdots$ & --- & --- & 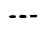 & --- & --- & $\cdots$ & - & --- & --- & -- & - \\
\hline$\$ 137$ & $\ldots$ & - & - & $\ldots$ & $\ldots$ & $=$ &.- &.- & -.. & -.. & -.. & $\ldots$ \\
\hline$\$ 137$ & -.. & --- & -.. & --- & --- & - & $\ldots$ & -- & $\ldots$ & -- & $\ldots$ & -- \\
\hline$\$ 138$ & --- & --- & --- & -.- & -.- & --- & ... & --- & --- & --- & -.- & -- \\
\hline
\end{tabular}

SILL. WEST OF WEST FORK OF NELLIE CREEK

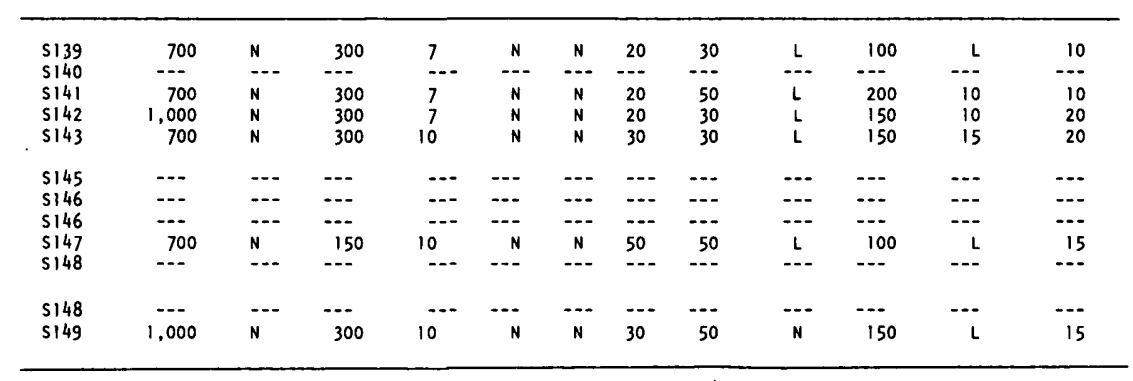


CONTIGUOUS AREAS, UNCOMPAHGRE PRIMITIVE AREA, COLO. E103

associated wallrocks, eastern contiguous area-Continued

\begin{tabular}{|c|c|c|c|}
\hline & $\begin{array}{l}\text { Chemical } \\
\text { analyses }\end{array}$ & Instrumental & \\
\hline Sample & $\frac{(\mathrm{ppm})}{\mathrm{F}}$ & $\begin{array}{l}\text { radioactivity } \\
\text { reading } 1 /\end{array}$ & Sample description \\
\hline
\end{tabular}

SILL. BETWEEN EAST AND WEST FORKS OF NELLIE CREEK--Cont inued

Intrusive rock--Continued

\begin{tabular}{|c|c|c|c|}
\hline $\begin{array}{l}S 117 \\
5118 \\
5119 \\
5120 \\
5121\end{array}$ & $\begin{array}{l}700 \\
--- \\
700 \\
500 \\
300\end{array}$ & $\begin{array}{r}0.15-0.475 \\
.15-.600 \\
.15-.600 \\
.15-.400 \\
.15-.500\end{array}$ & $\begin{array}{l}\text { Devitrified rhyolite. } \\
\text { Do. } \\
\text { Do. } \\
\text { Do. } \\
\text { Do. }\end{array}$ \\
\hline $\begin{array}{l}S 122 \\
S 123 \\
S 124 \\
S 125 \\
S 126\end{array}$ & $\begin{array}{l}<50 \\
=-- \\
--- \\
---\end{array}$ & $\begin{array}{l}.15-.525 \\
.15-.540 \\
.15-.475 \\
.15-.475 \\
.15-.475\end{array}$ & $\begin{array}{l}\text { Do. } \\
\text { Do. } \\
\text { Do. } \\
\text { Do. } \\
\text { Porous devitrified rhyolite. }\end{array}$ \\
\hline $\begin{array}{l}S 127 \\
S 128 \\
S 129 \\
S 130 \\
S 131\end{array}$ & $\begin{array}{l}--- \\
<50 \\
--- \\
200\end{array}$ & $\begin{array}{l}.15-.525 \\
.15-.450 \\
.15-.480 \\
.15-.475 \\
.15-.440\end{array}$ & $\begin{array}{l}\text { Devitrified rhyolite. } \\
\text { Do. } \\
\text { Do. } \\
\text { Do. } \\
\text { Do. }\end{array}$ \\
\hline $\begin{array}{r}s 132 \\
s 1338 \\
s 133 C \\
s 134 \\
S 135 A\end{array}$ & $\begin{array}{l}-- \\
<50 \\
<50 \\
<50\end{array}$ & $\begin{array}{l}.15-.360 \\
.15-.325 \\
.15-.425 \\
.15-.400 \\
.15-.400\end{array}$ & $\begin{array}{l}\text { Porous devitrified rhyolite. } \\
\text { Do. } \\
\text { Devitrified rhyolite. } \\
\text { Porous devitrified rhyolite. } \\
\text { Do. }\end{array}$ \\
\hline $\begin{array}{r}S 1358 \\
S 136 \\
S 137 \\
S 138 \\
S 138\end{array}$ & $\begin{array}{l}<50 \\
<50 \\
<-- \\
\cdots-\end{array}$ & $\begin{array}{l}.15-.500 \\
.15-.350 \\
.15-.425 \\
.15-.500 \\
1.5-.600\end{array}$ & $\begin{array}{l}\text { Devitrified rhyolite. } \\
\text { Do. } \\
\text { Do. } \\
\text { Do. } \\
\text { Sheared rhyolite with uranophane. }\end{array}$ \\
\hline
\end{tabular}

Wall rock--Cont inued

\begin{tabular}{|c|c|c|c|}
\hline $\begin{array}{r}S 133 A \\
s 133 \\
s 133 \\
s 133 \\
\$ 134\end{array}$ & $\begin{array}{l}<50 \\
--- \\
\cdots- \\
\cdots-\end{array}$ & $\begin{array}{l}0.15-0.175 \\
.15-.300 \\
.15-.275 \\
.15-.125 \\
.15-.175\end{array}$ & $\begin{array}{l}\text { Green sediments at contact. } \\
\text { Devitrified Crystal Lake Tuff. } \\
\text { Crystal Lake Tuff vitrophyre. } \\
\text { Red sediments near contact. } \\
\text { Fish Canyon Tuff. }\end{array}$ \\
\hline $\begin{array}{l}5137 \\
5137 \\
5138\end{array}$ & $\begin{array}{l}--- \\
\cdots-\end{array}$ & $\begin{array}{l}.15-.175 \\
.15-.160 \\
.15-.175\end{array}$ & $\begin{array}{c}\text { Do. } \\
\text { Sediments. } \\
\text { Do. }\end{array}$ \\
\hline
\end{tabular}

SILL WEST OF WEST FORK OF NELLIE CREEK--COnt inued

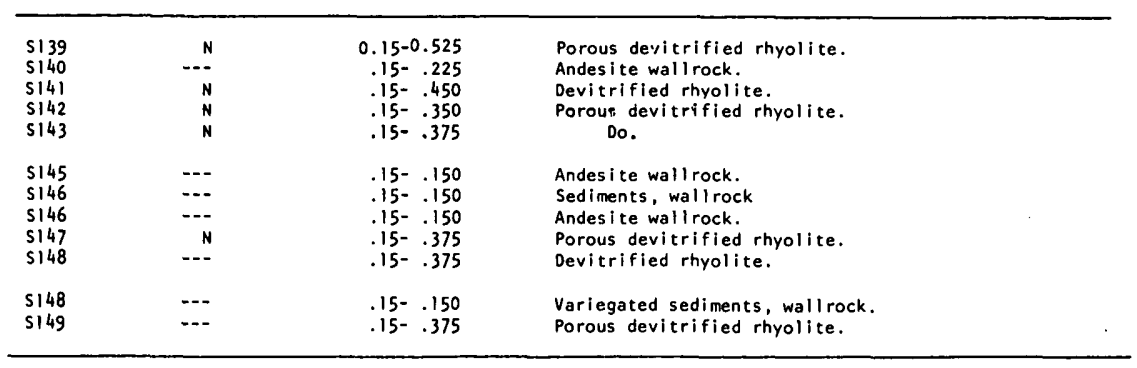

See footnote at the end of the table. 
TABLE 7.-Analyses of rhyolite intrusive rocks and

\begin{tabular}{|c|c|c|c|c|c|c|c|c|c|c|c|c|}
\hline \multirow[b]{2}{*}{ Sample } & \multicolumn{10}{|c|}{$\begin{array}{c}\text { Semiquantitative spectrographic analyses } \\
(\mathrm{ppm})\end{array}$} & \multirow[b]{2}{*}{$\begin{array}{c}v \\
(10) \\
\end{array}$} & \multirow[b]{2}{*}{$\begin{array}{r}\gamma \\
(10) \\
\end{array}$} \\
\hline & $\begin{array}{c}M n \\
(10)\end{array}$ & $\begin{array}{c}\mathrm{Ag} \\
(.5) \\
\end{array}$ & $\begin{array}{r}\mathrm{Ba} \\
(20) \\
\end{array}$ & $\begin{array}{l}\mathrm{Be} \\
(1)\end{array}$ & $\begin{array}{l}\mathrm{Cu} \\
(5) \\
\end{array}$ & $\begin{array}{l}\text { Mo } \\
\text { (5) }\end{array}$ & $\begin{array}{c}\mathrm{Nb} \\
(20)\end{array}$ & $\begin{array}{c}\mathrm{Pb} \\
(10)\end{array}$ & $\begin{array}{c}\mathrm{Sn} \\
(10) \\
\end{array}$ & $\begin{array}{c}\mathrm{sr} \\
(100)\end{array}$ & & \\
\hline \multicolumn{13}{|c|}{ SILL ON BROKEN HILL } \\
\hline G324A & $\ldots$ & --- & $\cdots$ & -.. & ... & -.- & --- & $\cdots$ & $\ldots$ & -- &.-- &.- \\
\hline $6324 B$ & -.- & --- & $\cdots$ & -- & -.. & -- & -- & $\cdots$ & --- & --- & -- & --- \\
\hline G $324 \mathrm{C}$ & -- & --- & $\cdots$ & -.. & -- & -- & ... &.- & -- & $-\cdots$ & $\ldots$ & -- \\
\hline 63240 & 1,000 & N & 50 & 10 & L & N & 30 & 50 & $\mathrm{~N}$ & N & L & 10 \\
\hline G324E & 1,500 & $\mathrm{~N}$ & 50 & 10 & $\mathrm{~L}$ & 5 & 20 & 70 & $\ddot{L}$ & $\mathrm{~N}$ & L & 10 \\
\hline G324F & 1,000 & $\mathrm{~N}$ & 30 & 20 & L & $\mathrm{N}$ & 50 & 50 & L & N & L & N \\
\hline G324G & 1,000 & N & 30 & 10 & $\bar{L}$ & N & 30 & 50 & $\mathrm{~N}$ & N & L & N \\
\hline G324H & 1,000 & N & 70 & 30 & $i$ & $\mathrm{~L}$ & 50 & 30 & $\mathrm{~N}$ & 300 & L & $\mathrm{L}$ \\
\hline 63241 & 1,000 & $\mathrm{~N}$ & 50 & 20 & 5 & $\mathrm{~N}$ & 30 & 50 & L & $\mathrm{N}$ & $\mathrm{N}$ & $L$ \\
\hline G324J & 700 & N & 50 & 15 & 10 & 5 & 50 & 50 & $\mathrm{~L}$ & $\mathrm{~N}$ & L & L \\
\hline G324K & 1,000 & $\mathrm{~N}$ & 70 & 15 & $\mathrm{~L}$ & $\mathrm{~N}$ & 30 & 50 & N & $\mathrm{N}$ & L & L \\
\hline G324L & 700 & $\mathrm{~N}$ & 50 & 15 & $\mathrm{~L}$ & $\mathrm{~N}$ & 50 & 50 & $\mathrm{~N}$ & $\mathrm{~N}$ & $\mathrm{~N}$ & $\mathrm{~L}$ \\
\hline G324M & 1,000 & N & 30 & 20 & $L$ & $\mathrm{~N}$ & 50 & 50 & $\mathrm{~L}$ & N & $\mathrm{N}$ & L \\
\hline G324N & 1,000 & $\mathrm{~N}$ & 70 & 20 & 20 & $\mathrm{~N}$ & 50 & 50 & $\mathrm{~N}$ & $\mathrm{~N}$ & $\mathrm{~N}$ & N \\
\hline 63240 & 700 & $\mathrm{~N}$ & 50 & 20 & 5 & $\mathrm{~N}$ & 50 & 50 & N & $\mathrm{N}$ & $\mathrm{N}$ & $\underline{L}$ \\
\hline
\end{tabular}

INTRUSIVES IN UPPER EL PASO CREEK

\begin{tabular}{|c|c|c|c|c|c|c|c|c|c|c|c|c|}
\hline $\begin{array}{l}\text { G325A } \\
\text { G325B } \\
\text { G325C } \\
\text { G325D } \\
\text { G326A }\end{array}$ & $\begin{array}{r}1,000 \\
1,000 \\
100 \\
1,000 \\
1,000\end{array}$ & $\begin{array}{l}N \\
N \\
N \\
N \\
N\end{array}$ & $\begin{array}{l}50 \\
30 \\
70 \\
50 \\
50\end{array}$ & $\begin{array}{l}15 \\
15 \\
20 \\
15 \\
15\end{array}$ & $\begin{array}{l}\mathbf{N} \\
\mathbf{N} \\
\mathbf{N} \\
\mathbf{N} \\
\mathbf{N}\end{array}$ & $\begin{array}{r}L \\
10 \\
15 \\
L \\
10\end{array}$ & $\begin{array}{l}50 \\
50 \\
50 \\
50 \\
30\end{array}$ & $\begin{array}{l}50 \\
70 \\
50 \\
50 \\
70\end{array}$ & $\begin{array}{r}N \\
N \\
20 \\
N \\
N\end{array}$ & $\begin{array}{r}\mathrm{N} \\
\mathrm{N} \\
500 \\
\mathrm{~N} \\
\mathrm{~N}\end{array}$ & $\begin{array}{l}N \\
N \\
N \\
N \\
N\end{array}$ & $\begin{array}{r}L \\
L \\
10 \\
L \\
L\end{array}$ \\
\hline $\begin{array}{l}\text { G326B } \\
\text { G326C } \\
\text { G } 3260 \\
\text { G } 327 A \\
\text { G327B }\end{array}$ & $\begin{array}{l}1,000 \\
1,500 \\
1,000 \\
1,000 \\
1,500\end{array}$ & $\begin{array}{l}N \\
N \\
N \\
N \\
N\end{array}$ & $\begin{array}{r}50 \\
30 \\
50 \\
30 \\
200\end{array}$ & $\begin{array}{l}15 \\
15 \\
20 \\
10 \\
15\end{array}$ & $\begin{array}{l}N \\
L \\
N \\
N \\
N\end{array}$ & $\begin{array}{r}10 \\
15 \\
N \\
5 \\
10\end{array}$ & $\begin{array}{l}50 \\
50 \\
50 \\
50 \\
30\end{array}$ & $\begin{array}{l}70 \\
50 \\
70 \\
70 \\
70\end{array}$ & $\begin{array}{l}\mathrm{L} \\
\mathrm{L} \\
\mathrm{L} \\
\mathrm{L} \\
\mathrm{L}\end{array}$ & $\begin{array}{r}200 \\
N \\
500 \\
N \\
N\end{array}$ & $\begin{array}{l}N \\
N \\
N \\
N \\
N\end{array}$ & $\begin{array}{r}\text { L } \\
10 \\
L \\
L \\
L\end{array}$ \\
\hline $6327 \mathrm{C}$ & 1,000 & N & 30 & 15 & $N$ & L & 50 & 70 & $L$ & $\mathrm{~N}$ & $\mathbf{L}$ & 10 \\
\hline \multicolumn{13}{|c|}{ LARSON CREEK PLUG } \\
\hline $\begin{array}{l}S 150 \\
S 151 \\
S 152 \\
S 153 \\
S 154\end{array}$ & $\begin{array}{c}- \\
1,000 \\
\cdots \\
500 \\
1,000\end{array}$ & $\begin{array}{c}\mathrm{N} \\
\mathrm{N} \\
\mathrm{N}\end{array}$ & $\begin{array}{l}\ldots- \\
300 \\
300 \\
300\end{array}$ & \begin{tabular}{l}
.-- \\
7 \\
\hdashline 7 \\
7
\end{tabular} & $\begin{array}{r}N \\
N \\
N \\
N\end{array}$ & $\begin{array}{r}- \\
N \\
N \\
N\end{array}$ & $\begin{array}{r}--- \\
30 \\
-- \\
30 \\
30\end{array}$ & $\begin{array}{r}-- \\
50 \\
-- \\
50 \\
50\end{array}$ & $\begin{array}{c}-- \\
L \\
L\end{array}$ & $\begin{array}{l}-.- \\
150 \\
--- \\
150 \\
150\end{array}$ & $\begin{array}{r}10 \\
10 \\
15\end{array}$ & $\begin{array}{r}--- \\
15 \\
-- \\
20 \\
30\end{array}$ \\
\hline $\begin{array}{l}S 155 \\
S 156 \\
S 157 \\
S 158 \\
S 159\end{array}$ & $\begin{array}{l}700 \\
700 \\
700 \\
700 \\
700\end{array}$ & $\begin{array}{l}\mathrm{N} \\
\mathrm{N} \\
\mathrm{N} \\
\mathrm{N} \\
\mathrm{N}\end{array}$ & $\begin{array}{l}500 \\
300 \\
300 \\
300 \\
300\end{array}$ & $\begin{array}{l}7 \\
7 \\
7 \\
7 \\
7\end{array}$ & $\begin{array}{l}N \\
N \\
N \\
N \\
N\end{array}$ & $\begin{array}{l}N \\
N \\
N \\
N \\
N\end{array}$ & $\begin{array}{l}30 \\
20 \\
20 \\
30 \\
20\end{array}$ & $\begin{array}{l}50 \\
30 \\
30 \\
30 \\
30\end{array}$ & $\begin{array}{l}L \\
L \\
N \\
N \\
N\end{array}$ & $\begin{array}{l}150 \\
100 \\
100 \\
100 \\
100\end{array}$ & $\begin{array}{l}15 \\
10 \\
15 \\
15 \\
10\end{array}$ & $\begin{array}{l}15 \\
20 \\
20 \\
20 \\
10\end{array}$ \\
\hline $\begin{array}{l}\$ 160 \\
5161 \\
5162\end{array}$ & $\begin{array}{l}700 \\
700 \\
500\end{array}$ & $\begin{array}{l}N \\
N \\
N\end{array}$ & $\begin{array}{l}300 \\
300 \\
150\end{array}$ & $\begin{array}{l}7 \\
7 \\
7\end{array}$ & $\begin{array}{l}N \\
N \\
N\end{array}$ & $\begin{array}{l}\mathbf{N} \\
\mathbf{N} \\
\mathbf{N}\end{array}$ & $\begin{array}{l}20 \\
20 \\
20\end{array}$ & $\begin{array}{l}30 \\
50 \\
50\end{array}$ & $\begin{array}{l}L \\
L \\
L\end{array}$ & $\begin{array}{r}150 \\
100 \\
L\end{array}$ & $\begin{array}{r}15 \\
10 \\
L\end{array}$ & $\begin{array}{r}15 \\
15 \\
15\end{array}$ \\
\hline
\end{tabular}


CONTIGUOUS AREAS, UNCOMPAHGRE PRIMITIVE AREA, COLO. E105

associated wallrocks, eastern area contiguous-Continued

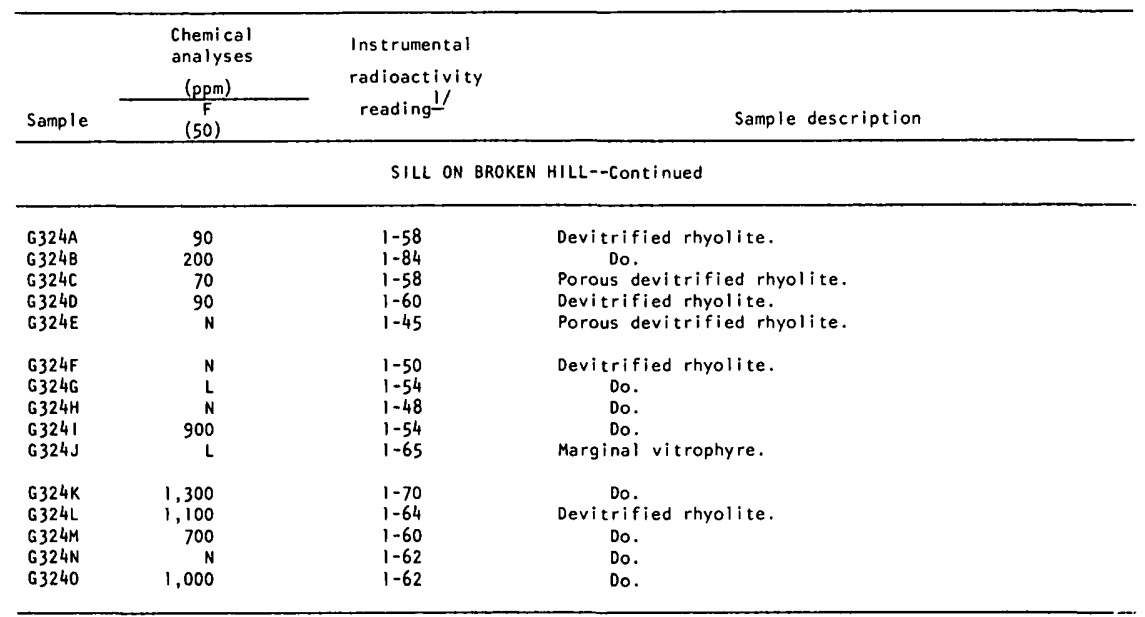

INTRUSIVES IN UPPER EL PASO CREEK--Continued

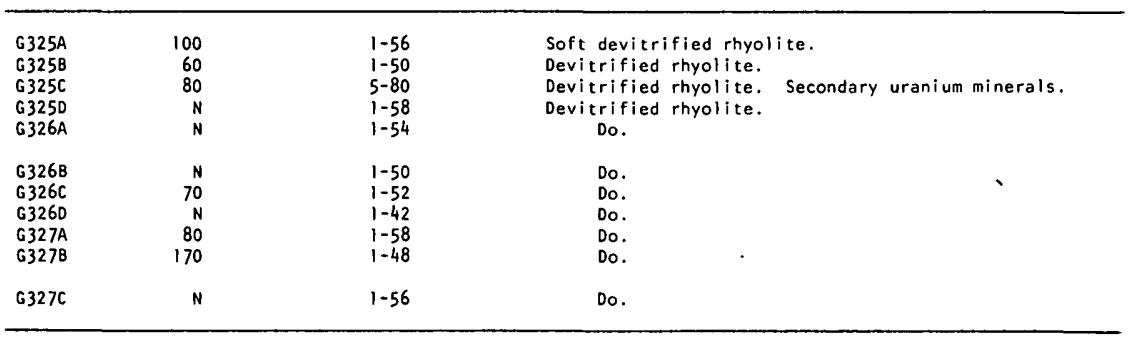

LARSON CREEK PLUG---CONTinUed

\begin{tabular}{|c|c|c|c|}
\hline $\begin{array}{l}\$ 150 \\
\$ 151 \\
S 152 \\
S 153 \\
S 154\end{array}$ & 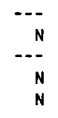 & $\begin{array}{l}0.15-0.225 \\
.15-.325 \\
.15-.325 \\
.15-.325 \\
.15-.375\end{array}$ & $\begin{array}{l}\text { Quartz latite wall rock. } \\
\text { Porous devitrified rhyolite. } \\
\text { Do. } \\
\text { Do. } \\
\text { Do. }\end{array}$ \\
\hline $\begin{array}{l}\$ 155 \\
\$ 156 \\
\$ 157 \\
\$ 158 \\
\$ 159\end{array}$ & $\begin{array}{l}\mathrm{N} \\
\mathrm{N} \\
\mathrm{N} \\
\mathrm{N} \\
\mathrm{N}\end{array}$ & $\begin{array}{l}.15-.500 \\
.15-.375 \\
.15-.425 \\
.15-.425 \\
.15-.500\end{array}$ & $\begin{array}{l}\text { Devitrified rhyolite. } \\
\text { Porous devitrified rhyolite. } \\
\text { Devitrified rhyolite. } \\
\text { Do. } \\
\text { Do. }\end{array}$ \\
\hline $\begin{array}{l}S 160 \\
\text { S161 } \\
\text { S162 }\end{array}$ & $\begin{array}{r}170 \\
\mathrm{~N} \\
\mathrm{~N}\end{array}$ & $\begin{array}{l}.15-.475 \\
.15-.450 \\
.15-.475\end{array}$ & $\begin{array}{l}\text { Do. } \\
\text { Do. } \\
\text { Do. }\end{array}$ \\
\hline
\end{tabular}

1/ Readings are uncalibrated field measurements. Those on the plug along the East fork of Nellie Creek, sill between the East and West Forks of Nellie Creek, sill west of the West Fork of Nellie Creek, and Larson Creek plug were made with Precision Model 1118 Deluxe Scintillator, and those on the sill on Broken Hill and the intrusives in upper El Paso Creek were made with Mount Sopris Model SC 131 Scintillator. 
TABLE 8.-Uranium, thorium, fluorine, and radioactivity in rhyolite intrusives and associated rocks

[ppm, parts per million, ..., not analyzed]

\begin{tabular}{|c|c|c|c|c|c|c|}
\hline Sample & $\begin{array}{l}\mathrm{eU}{ }^{\prime \prime} \\
(\mathrm{ppm})\end{array}$ & $\begin{array}{l}\mathrm{U} \underline{2 \prime} \\
(\mathrm{ppm})\end{array}$ & $\begin{array}{l}\mathrm{Th} \underline{2 \prime} \\
(\mathrm{ppm})\end{array}$ & $\begin{array}{c}F \\
(\mathrm{ppm})\end{array}$ & $\begin{array}{l}\text { Instrumental } \\
\text { radioactivity } \\
\text { reading }\end{array}$ & Sample description \\
\hline
\end{tabular}

EAST NELLIE CREEK PLUG

Intrusive rock

\begin{tabular}{|c|c|c|c|c|c|c|c|}
\hline $\begin{array}{r}\$ 103 \\
\$ 105 \\
\$ 110 A \\
\text { S112A }\end{array}$ & $\begin{array}{l}60 \\
60 \\
60 \\
50\end{array}$ & $\begin{array}{l}22.1 \\
23.2 \\
42.2 \\
24.9\end{array}$ & $\begin{array}{l}55.2 \\
47.0 \\
57.5 \\
50.5\end{array}$ & $\begin{array}{l}2.6 \\
2.0 \\
1.4 \\
2.0\end{array}$ & $\begin{array}{r}375 \\
<50 \\
80 \\
300\end{array}$ & $\begin{array}{l}0.15-0.570 \\
.15-.575 \\
.15-.660 \\
.15-.600\end{array}$ & $\begin{array}{l}\text { Devitrified rhyolite. } \\
\text { Do. } \\
\text { Marginal vitrophyre. } \\
\text { Devitrified rhyolite. }\end{array}$ \\
\hline \multicolumn{8}{|c|}{ Wall rock } \\
\hline $\begin{array}{l}\$ 107 \\
5108 \\
5111\end{array}$ & $\begin{array}{l}40 \\
50 \\
30\end{array}$ & $\begin{array}{r}7.7 \\
25.6 \\
8.1\end{array}$ & $\begin{array}{l}17.6 \\
54.6 \\
14.4\end{array}$ & $\begin{array}{l}2.3 \\
2.1 \\
1.8\end{array}$ & $\begin{array}{l}<50 \\
<50 \\
100\end{array}$ & $\begin{array}{r}0.15-0.375 \\
.15-.340 \\
.15-.425\end{array}$ & $\begin{array}{c}\text { Crystal Lake Tuff. } \\
\text { Do. } \\
\text { Bentonitic sediments. }\end{array}$ \\
\hline
\end{tabular}

SILL BETWEEN EAST AND WEST NELLIE CREEKS

Intrus ive rock

\begin{tabular}{rrrrrrrl}
\hline S117 & 40 & 8.2 & 56.6 & 6.9 & 700 & $0.15-0.475$ & Devitrified rhyolite. \\
S119 & 60 & 29.3 & 50.9 & 1.7 & 700 & $.15-.600$ & Do. \\
S121 & 40 & 17.4 & 53.6 & 3.1 & 300 & $.15-.500$ & Do. \\
S122 & 60 & 32.4 & 47.6 & 1.5 & $<50$ & $.15-.525$ & Do. \\
S125 & 50 & 21.4 & 38.6 & 1.9 & $<50$ & $.15-.475$ & Do. \\
& & & & & & \\
S128 & 60 & 23.5 & 52.2 & 2.2 & $<50$ & $.15-.450$ & Do. \\
S130 & 50 & 15.9 & 58.5 & 3.7 & 200 & $.15-.475$ & Do. \\
S133B & 40 & 12.9 & 43.6 & 3.4 & $<50$ & $.15-.325$ & Do. \\
S133C & 50 & 16.3 & 42.8 & 2.6 & $<50$ & $.15-.425$ & Do. \\
S135A & 40 & 15.4 & 60.9 & 4.0 & $<50$ & $.15-.400$ & Do. \\
S135B & 50 & 22.8 & 23.5 & 1.0 & $<50$ & $.15-.500$ & Do. \\
S137 & 50 & 16.7 & 46.6 & 2.8 & $<50$ & $.15-.425$ & Do. \\
\hline
\end{tabular}

SILL WEST OF WEST NELLIE CREEK

Intrusive rock

\begin{tabular}{|c|c|c|c|c|c|c|c|}
\hline $\begin{array}{l}5139 \\
S 141 \\
S 142 \\
S 143 \\
5147\end{array}$ & $\begin{array}{l}60 \\
50 \\
50 \\
50 \\
50\end{array}$ & $\begin{array}{l}26.8 \\
16.4 \\
13.5 \\
24.4 \\
14.8\end{array}$ & $\begin{array}{l}45.4 \\
39.7 \\
46.3 \\
43.2 \\
49.5\end{array}$ & $\begin{array}{l}1.7 \\
2.4 \\
3.4 \\
1.8 \\
3.4\end{array}$ & $\begin{array}{l}<50 \\
<50 \\
<50 \\
<50 \\
<50\end{array}$ & $\begin{array}{r}0.15-0.525 \\
.15-.450 \\
.15-.350 \\
.15-.375 \\
.15-.375\end{array}$ & $\begin{array}{l}\text { Porous devitrified rhyolite. } \\
\text { Devitrified rhyolite. } \\
\text { Porous devitrified rhyolite. } \\
\text { Do. } \\
\text { Do. }\end{array}$ \\
\hline 5149 & 60 & 22.4 & 50.2 & 2.3 & $<50$ & $.15-.375$ & Do. \\
\hline \multicolumn{8}{|c|}{ LARSON CREEK PLUG } \\
\hline \multicolumn{8}{|c|}{ Intrusive rock } \\
\hline $\begin{array}{l}\$ 151 \\
\$ 153 \\
\$ 156 \\
S 158 \\
\$ 159\end{array}$ & $\begin{array}{l}50 \\
50 \\
40 \\
40 \\
40\end{array}$ & $\begin{array}{l}19.2 \\
10.0 \\
10.9 \\
12.1 \\
13.9\end{array}$ & $\begin{array}{l}45.0 \\
48.4 \\
46.7 \\
47.0 \\
45.3\end{array}$ & $\begin{array}{l}2.3 \\
4.8 \\
4.3 \\
3.9 \\
3.3\end{array}$ & $\begin{array}{l}<50 \\
<50 \\
<50 \\
<50 \\
<50\end{array}$ & $\begin{array}{r}0.15-0.325 \\
.15-.325 \\
.15-.375 \\
.15-.425 \\
.15-.500\end{array}$ & $\begin{array}{l}\text { Porous devitrified rhyolite. } \\
\text { Do. } \\
\text { Do. } \\
\text { Devitrified rhyolite. } \\
\text { Do. }\end{array}$ \\
\hline$\$ 161$ & 40 & 12.2 & 40.2 & 3.3 & $<50$ & $.15-.450$ & Do. \\
\hline
\end{tabular}

See footnotes at the end of the table. 
CONTIGUOUS AREAS, UNCOMPAHGRE PRIMITIVE AREA, COLO. E107

TABLE 8.-Uranium, thorium, fluorine, and radioactivity in rhyolite intrusives and associated rocks-Continued

\begin{tabular}{|c|c|c|c|c|c|c|}
\hline Sample & $\begin{array}{l}\mathrm{eU}{ }^{\mathrm{l}} \\
(\mathrm{ppm})\end{array}$ & $\begin{array}{c}u \stackrel{2 \prime}{ } \\
\text { (ppm) }\end{array}$ & $\begin{array}{c}\mathrm{Th}^{2} \text { I } \\
(\mathrm{ppm})\end{array}$ & $\underset{(\mathrm{ppm})}{\mathbf{F}}$ & $\begin{array}{l}\text { Instrumental } \\
\text { radioactivity } \\
\text { reading }\end{array}$ & Sample description \\
\hline
\end{tabular}

INTRUSIVES IN UPPER EL PASO CREEK

Intrusive rock

\begin{tabular}{|c|c|c|c|c|c|c|c|}
\hline $\begin{array}{l}\text { G325A } \\
6325 B \\
G 325 C \\
63250\end{array}$ & $\begin{array}{r}70 \\
60 \\
580 \\
60\end{array}$ & $\begin{array}{r}36.2 \\
26.2 \\
539.4\end{array}$ & $\begin{array}{l}46.7 \\
49.7 \\
10.9 \\
49.3\end{array}$ & $\begin{array}{l}1.3 \\
1.9 \\
.02 \\
1.4\end{array}$ & $\begin{array}{r}100 \\
60 \\
80 \\
\end{array}$ & $\begin{array}{l}1-56 \\
1-50 \\
5-80 \\
1-58\end{array}$ & $\begin{array}{l}\text { Soft devitrified rhyolite. } \\
\text { Devitrified rhyolite. } \\
\text { Devitrified rhyolite. } \\
\text { Secondary uranium minerals. } \\
\text { Devitrified rhyolite. }\end{array}$ \\
\hline $\begin{array}{l}63250 \\
\text { G326A }\end{array}$ & $\begin{array}{l}60 \\
60\end{array}$ & $\begin{array}{l}35.7 \\
36.9\end{array}$ & $\begin{array}{l}49.3 \\
47.1\end{array}$ & $\begin{array}{l}1.4 \\
1.3\end{array}$ & $\begin{array}{l}<50 \\
<50\end{array}$ & $\begin{array}{l}1-58 \\
1-54\end{array}$ & $\begin{array}{l}\text { Devitrified rhyolite. } \\
\text { Do. }\end{array}$ \\
\hline $\begin{array}{l}G 326 C \\
G 327 A \\
G 327 C\end{array}$ & $\begin{array}{l}60 \\
60 \\
50\end{array}$ & $\begin{array}{l}28.7 \\
32.7 \\
26.8\end{array}$ & $\begin{array}{l}53.2 \\
58.1 \\
54.9\end{array}$ & $\begin{array}{l}1.9 \\
1.9 \\
2.1\end{array}$ & $\begin{array}{r}70 \\
80 \\
<50\end{array}$ & $\begin{array}{l}1-52 \\
1-58 \\
1-56\end{array}$ & $\begin{array}{l}\text { Do. } \\
\text { Do. } \\
\text { Do. }\end{array}$ \\
\hline L47 & 70 & 40.0 & 63.5 & 1.6 & --- & -.. & $\begin{array}{l}\text { Marginal vitrophyre, East } \\
\text { Nellie Creek plug. }\end{array}$ \\
\hline 147 & $\cdots$ & -37.5 & $4 / 55.1$ & 1.5 & $\cdots$ & --- & Do. \\
\hline
\end{tabular}

I' Beta-gamma scaler method, E. J. Fennelly, analyst.

2f Delayed neutron method, H. T. Millard, analyst.

3/ Readings are uncalibrated field measurements. Those on samples $5|n 3-16|$ were made with Precision Model 111 B Deluxe Scintillator, and those on samples $6325 A-6327 C$ were made with Mount Sopris Model SC 131 Scintillator.

4/ Gamma-ray spectrometry, C. M. Bunker, analyst. 
TABLE 11.-Analyses of samples from study areas

[Semiquantitative spectrographic analyses, fire assays, radiometric analyses for $\mathrm{U}_{3} \mathrm{O}_{8}, \mathrm{X}$-ray fluorescence for As, at the Reno Metallurgy Research Center, U.S. Bureau of Mines. Detection limits are in parentheses under trace amount under $\mathrm{Au}$ and $\mathrm{Ag}$; M, major quantity (greater than 7 percent); T. R. S., designates location location approximate; $t$, additional data given by sample number in footnote at end of table; na, not The following elements were looked for and not found or were found in amounts normal for rocks of Bi, Cd, Co, Ga, Hf, In, La, Li, Nb, P, Pt, Re, Sc, Sn, Ta, Te, Tl, W, and Y; Na and Si were major

\begin{tabular}{|c|c|c|c|c|c|c|c|c|c|c|c|c|c|}
\hline \multirow[b]{3}{*}{ Sample } & \multirow[b]{3}{*}{$\begin{array}{l}\text { Location } \\
\text { T. R. S. }\end{array}$} & \multicolumn{12}{|c|}{ Semiquantitative spectrographic analyses } \\
\hline & & \multicolumn{6}{|c|}{ percent } & \multicolumn{6}{|c|}{ ppm } \\
\hline & & $\begin{array}{c}\mathrm{A} 1 \\
(.003) \\
\end{array}$ & $\begin{array}{c}\mathrm{Ca} \\
(.02) \\
\end{array}$ & $\begin{array}{c}\mathrm{Fe} \\
(.004)\end{array}$ & $\begin{array}{c}\mathrm{Mg} \\
(.004) \\
\end{array}$ & $\begin{array}{c}\mathrm{Mn} \\
(.003) \\
\end{array}$ & $\begin{array}{c}\mathrm{Ti} \\
(.001) \\
\end{array}$ & $\begin{array}{c}\text { B } \\
(100)\end{array}$ & $\begin{array}{c}\mathrm{Ba} \\
(1,000)\end{array}$ & $\begin{array}{c}\mathrm{Cr} \\
(30) \\
\end{array}$ & $\begin{array}{r}\mathrm{Cu} \\
(20) \\
\end{array}$ & $\begin{array}{c}\text { Mo } \\
(20) \\
\end{array}$ & $\begin{array}{c}\mathrm{N1} \\
(20) \\
\end{array}$ \\
\hline $1+$ & $46-5-25 *$ & $>5.0$ & 1.0 & M & 3.0 & 0.4 & 2.0 & - & - & 300 & 60 & - & - \\
\hline 2 & $46-5-25 *$ & 4 & 4 & 2.0 & .8 & .05 & .2 & - & - & - & 30 & - & - \\
\hline 3 & $45-4-6 \star$ & M & 1 & 4 & .8 & .1 & .4 & 100 & 2,000 & 60 & 20 & $<20$ & - \\
\hline 4 & $45-4-4 *$ & $\mathrm{M}$ & M & 7 & 3 & .2 & .4 & - & 1,000 & 100 & 60 & - & 40 \\
\hline 5 & $45-4-4 *$ & M & M & 6 & .8 & .2 & .4 & $<100$ & 1,000 & 100 & 60 & - & 40 \\
\hline $6 t$ & $45-4-16 \star$ & $M$ & 1 & 7 & .8 & .2 & .2 & - & 1,000 & 60 & 80 & $<20$ & - \\
\hline 7 & $44-4-2$ & 3 & .02 & 1 & .006 & .01 & .02 & - & 4,000 & 30 & 20 & - & - \\
\hline 8 & $44-4-2$ & M & .06 & 2 & .02 & .01 & .05 & - & $<1,000$ & 100 & 40 & - & - \\
\hline 9 & $44-4-11$ & 4 & .06 & 2 & .2 & .03 & .1 & - & $<1,000$ & 70 & 30 & - & - \\
\hline 10 & $44-4-11$ & 3 & .06 & 2 & .2 & .03 & .1 & - & - & 70 & 30 & - & - \\
\hline 11 & $44-4-11$ & 4 & .5 & 2 & .8 & .1 & .2 & - & - & 70 & 40 & - & - \\
\hline 12 & $44-4-11$ & 4 & .06 & 2 & .2 & .05 & .2 & - & - & - & 30 & - & - \\
\hline 13 & $44-4-11$ & $>5$ & $M$ & 3 & .4 & .1 & .1 & - & $<1,000$ & 100 & 300 & - & - \\
\hline 14 & $44-4-11$ & .04 & M & 2 & .2 & .2 & .002 & - & - & - & - & - & - \\
\hline 15 & $44-4-11$ & 2 & 4 & 4 & .2 & .4 & .05 & - & - & - & $<20$ & - & - \\
\hline 16 & $44-4-10$ & $M$ & .06 & 3 & .2 & .01 & .2 & - & 1,000 & 100 & 20 & $<20$ & - \\
\hline 17 & $44-4-15$ & $>5$ & 4 & 5 & .8 & .3 & .2 & - & - & 100 & 80 & - & - \\
\hline 18 & $44-4-15$ & $M$ & .03 & 2 & .4 & .01 & .2 & $<100$ & 40,000 & 100 & 40 & 20 & - \\
\hline 19 & $44-4-15$ & $M$ & .3 & 4 & .6 & .02 & .2 & $<100$ & 3,000 & 100 & 20 & 30 & - \\
\hline 20 & $44-4-15$ & $M$ & .3 & 3 & .4 & .01 & .2 & $<100$ & - & 100 & 20 & $<20$ & - \\
\hline 21 & $44-4-15$ & 4 & .03 & 3 & .2 & .03 & .1 & - & - & 200 & 60 & 100 & 20 \\
\hline 22 & $44-4-15$ & $>5$ & 2 & 3 & .8 & 2 & .4 & - & 4,000 & 100 & 60 & - & - \\
\hline 23 & $44-4-15$ & 4 & .06 & 3 & .2 & .05 & .1 & - & - & 300 & 80 & 20 & 40 \\
\hline 24 & $44-4-28$ & 5 & .06 & 3 & .2 & .02 & .1 & - & 30,000 & 100 & 400 & - & - \\
\hline 25 & $44-4-28$ & 5 & .06 & 2 & .2 & .02 & .1 & - & 30,000 & 100 & 300 & - & - \\
\hline 26 & $44-4-28$ & M & .3 & 1 & .4 & 3 & .2 & 300 & 2,000 & 60 & 200 & $<20$ & - \\
\hline 27 & $44-4-28$ & $M$ & .06 & .5 & .4 & .8 & .1 & 300 & 1,000 & 60 & 40 & $<20$ & - \\
\hline 28 & $44-4-28$ & 2 & .1 & 2 & .2 & .1 & .1 & 200 & 1,000 & 60 & 200 & $<20$ & - \\
\hline 29 & $44-4-28$ & $\mathrm{M}$ & .06 & 4 & .8 & .2 & .2 & 300 & $<1,000$ & 100 & 40 & - & - \\
\hline 30 & $44-4-28$ & $M$ & .03 & 4 & .2 & .2 & .1 & 200 & 4,000 & 300 & 300 & $<20$ & - \\
\hline $31 \dagger$ & $44-4-28$ & 3 & .06 & 4 & .05 & .05 & .05 & - & $M$ & 300 & 300 & - & - \\
\hline $32+$ & $44-4-28$ & 5 & .03 & 2 & .2 & .05 & .2 & 200 & $<1,000$ & so & 50 & - & - \\
\hline $33 \dagger$ & $44-4-28$ & 3 & .03 & 3 & .05 & .1 & .05 & 100 & 20,000 & 300 & 300 & - & - \\
\hline $34 \div$ & $44-4-28$ & 4 & .06 & 2 & .02 & .01 & .05 & - & M & 60 & 400 & 20 & - \\
\hline $35 t$ & $44-4-28$ & M & .06 & 3 & .02 & .02 & .05 & - & 20,000 & 60 & 400 & 20 & - \\
\hline 36 & $44-4-28$ & $M$ & .1 & 3 & .1 & .05 & .2 & 300 & - & 60 & 80 & - & - \\
\hline $37 r$ & $44-4-28$ & 3 & .03 & 2 & .06 & .02 & .05 & - & 40,000 & 100 & 10,000 & - & - \\
\hline 38 & $44-4-28$ & M & .1 & 5 & .2 & 1.6 & .2 & 100 & 5,000 & 60 & 80 & 30 & - \\
\hline 39 & $44-4-28$ & $M$ & .03 & 3 & .1 & .05 & .1 & - & 1,000 & 60 & 40 & 70 & - \\
\hline 40 & $44-4-28$ & 5 & .03 & 3 & .4 & .02 & .2 & 200 & $<1,000$ & 50 & 40 & - & - \\
\hline 41 & $44-4-28$ & $>5$ & .06 & .8 & .2 & .05 & .2 & - & - & 200 & 40 & $<20$ & - \\
\hline $42+$ & $44-4-28$ & 2 & .02 & 5 & .01 & .05 & .03 & 100 & 40,000 & 500 & 600 & 100 & 40 \\
\hline 43 & $44-4-28$ & 3 & .03 & .8 & .02 & .05 & .03 & - & 4,000 & 300 & 80 & $<20$ & 20 \\
\hline 44 & $44-4-28$ & 5 & .03 & 4 & .4 & .05 & .1 & 200 & 20,000 & 60 & 80 & 30 & - \\
\hline 45 & $44-4-28$ & 5 & .03 & 4 & .2 & .1 & .1 & 200 & 5,000 & 100 & 160 & 30 & - \\
\hline 46 & $44-4-32$ & M & .03 & 2 & .4 & .2 & .2 & 200 & 1,000 & 100 & 80 & 30 & - \\
\hline 47 & $44-4-32$ & $M$ & .2 & 3 & .2 & .05 & .05 & - & $<1,000$ & 100 & 80 & 20 & - \\
\hline 48 & $44-4-32$ & 3 & .3 & 3 & .2 & .05 & .05 & - & 20,000 & 100 & 160 & 30 & - \\
\hline $49 \div$ & $44-4-32$ & .2 & .06 & 4 & .02 & .05 & .002 & - & $M$ & 100 & 600 & 70 & - \\
\hline $50+$ & $44-4-32$ & 2 & .02 & 1 & .2 & .02 & .02 & $<100$ & 1,000 & 60 & 600 & 70 & - \\
\hline $51 \div$ & $44-4-32$ & is & .03 & 2 & .4 & .1 & .2 & 300 & 20,000 & 100 & 300 & 70 & - \\
\hline $52 \div$ & $44-4-32$ & 5 & .1 & 3 & .2 & M & .05 & - & - & 30 & 1,000 & 20 & - \\
\hline $53 \div$ & $44-4-32$ & 3 & .1 & 4 & .1 & $\mathrm{M}$ & .05 & - & - & 30 & 3,000 & - & - \\
\hline 54 & $44-4-30 \star$ & $\mathrm{M}$ & 1 & 4 & .4 & .05 & .2 & - & 2,000 & 100 & 40 & - & - \\
\hline 55 & $44-4-30 *$ & 5 & .3 & 2 & .4 & .05 & .1 & - & 3,000 & 60 & 40 & - & - \\
\hline 56 & $44-4-30 *$ & 5 & .1 & 5 & .4 & .2 & .1 & 100 & 1,000 & 100 & 40 & - & - \\
\hline 57 & $44-4-19 *$ & M & $>4^{\circ}$ & 7 & 1.5 & .3 & .4 & 100 & 2,000 & 60 & 40 & - & - \\
\hline 58 & $44-4-19 *$ & 5 & 2 & 6 & 1 & .2 & .4 & 100 & - & 60 & 40 & - & - \\
\hline $59 \div$ & $44-5-13 *$ & 5 & 4 & 7 & 3 & .2 & .2 & - & - & 30 & 30 & - & - \\
\hline 60 & $44-5-13 *$ & $M$ & $>4$ & 7 & 1.5 & .2 & .8 & 100 & 1,000 & 60 & 40 & - & - \\
\hline
\end{tabular}




\section{CONTIGUOUS AREAS, UNCOMPAHGRE PRIMITIVE AREA, COLO. E109}

\section{contiguous to the Uncompahgre Primitive Area}

$\mathrm{Sb}$, and $\mathrm{W}$, activation analyses for $\mathrm{Ba}$, and atomic absorption (AA) for all other elements were performed elements listed. - , looked for but not detected; $\leqslant$, less than amount shown; $>$. greater than amount shown; $\mathrm{T}$, of sample by township north (T) and range west (R) of New Mexico Principal Meridian, and section (S); * analyzed.

the type sampled and were judged not to be significant except as noted in the footnotes at end of table: Be, constituents in almost all samples]

\begin{tabular}{|c|c|c|c|c|c|c|c|c|c|c|}
\hline \multirow[b]{3}{*}{ Sample } & \multicolumn{4}{|c|}{$\begin{array}{c}\text { Semiquantitative spectrographic } \\
\text { analyses--Continued }\end{array}$} & \multirow{2}{*}{\multicolumn{2}{|c|}{$\frac{\text { Fire assay }}{\text { oz/ton }}$}} & \multirow{2}{*}{\multicolumn{3}{|c|}{$\begin{array}{c}\begin{array}{c}\text { Atomic absorption } \\
\text { analyses }\end{array} \\
\text { percent }\end{array}$}} & \multirow{3}{*}{ Sample data } \\
\hline & \multicolumn{4}{|c|}{$\mathrm{ppm}$} & & & & & & \\
\hline & $\begin{array}{c}\mathrm{Pb} \\
(100)\end{array}$ & $\begin{array}{c}\mathrm{Sr} \\
(1,000) \\
\end{array}$ & $\begin{array}{c}\mathrm{Zn} \\
(1,000) \\
\end{array}$ & $\begin{array}{c}\mathrm{Zr} \\
(70) \\
\end{array}$ & $\mathrm{Au}$ & $\mathrm{Ag}$ & $\mathrm{Cu}$ & $\mathrm{pb}$ & $2 n$ & \\
\hline $1 \%$ & $<100$ & - & - & 300 & - & - & na & na & na & Stream-Danned concentrate \\
\hline 2 & - & - & - & $<70$ & $\mathrm{~T}$ & $\mathrm{~T}$ & na & na & na & Stream-sediment \\
\hline 3 & 200 & - & - & 300 & - & .1 & na & na & na & Do. \\
\hline 4 & 200 & 1,000 & - & $<70$ & - & .1 & na & na & na & Outcrop-ch1p-specimen \\
\hline 5 & 200 & $<1,000$ & - & $<70$ & $\mathrm{~T}$ & $\mathrm{~T}$ & na & na & na & Dutcrop(talus)-specimen \\
\hline $6+$ & 400 & - & - & 300 & - & .1 & na & na & ma & Outcrop-chip-6 ft. \\
\hline 7 & 400 & - & - & $<70$ & $T$ & 3 & na & na & na & Adit-dump (20 tons)-grab \\
\hline 8 & 300 & - & - & $<70$ & $\mathrm{~T}$ & .3 & na & na & na & Ad1 $t$-face-chip-3.5 f $t$ \\
\hline 9 & 100 & - & - & 70 & $\mathrm{~T}$ & .1 & na & na & na & Outcrop-ve1n-chip-1.25 ft. \\
\hline 10 & 100 & - & - & $<70$ & $\mathrm{~T}$ & $\mathrm{~T}$ & na & na & na & Outcrop-vein-ch1p-1.75 ft. \\
\hline 11 & $<100$ & - & - & 70 & $\mathrm{~T}$ & - & na & na & na & Adit-dump (200 to'ns) - $8 \mathrm{rab}$ \\
\hline 12 & - & - & - & $<70$ & $\mathrm{~T}$ & $\mathrm{~T}$ & na & na & na & Adit-portal-chip-5 ft. \\
\hline 13 & 100 & 1,000 & - & 70 & $\mathrm{~T}$ & .1 & na & na & na & Adit-dump $(1,000$ tons $)-$ grab \\
\hline 14 & - & 4,000 & - & - & $\mathrm{T}$ & $\mathrm{T}$ & na & na & na & Do. \\
\hline 15 & - & $<1,000$ & - & - & - & - & na & na & na & Ad1t-portal-stream-sediment \\
\hline 16 & - & - & - & $<70$ & $\mathrm{~T}$ & - & na & na & na & Pit-dump (15 tons)-grab \\
\hline 17 & - & - & - & 70 & $\mathrm{~T}$ & .2 & na & na & กล & Adit-dump ( 800 tons) -grab \\
\hline 18 & 5,000 & - & - & $<70$ & $\mathrm{~T}$ & - & na & 0.10 & 0.03 & Adit-portal-chip-0.5 ft. \\
\hline 19 & 700 & - & - & $<70$ & $\mathrm{~T}$ & - & na & na & na & Adit-stockptle (100 lb.)-grab \\
\hline 20 & 100 & - & - & $<70$ & $\mathrm{~T}$ & .1 & na & na & na & Adit-portal-vein-chip-7 ft. \\
\hline 21 & 700 & - & - & 70 & $\mathrm{~T}$ & .2 & na & na & na & Pit-dump (20 tons)-grab \\
\hline 22 & $<100$ & 1,000 & - & 70 & - & - & na & na & na & Outcrop(talus)-specimen \\
\hline 23 & 700 & - & - & 70 & - & $\mathrm{T}$ & na & na & na & Pit-vein-chip-2 ft. \\
\hline 24 & 6,000 & - & - & 70 & - & 2.2 & 0.2 & .05 & na & P1t-vein-chip-1 ft. \\
\hline 25 & 1,500 & - & - & 70 & - & 1.6 & .1 & .02 & na & Pit-dump (15 tons)-grab \\
\hline 26 & 10,000 & - & - & $<70$ & $\mathrm{~T}$ & .01 & na & .21 & na & Adit-vein-chip-2 ft. \\
\hline 27 & 400 & - & - & $<70$ & $\mathrm{~T}$ & - & na & na & na & Adit-ve1n-chip-5 ft. \\
\hline 28 & 2,000 & - & - & $<70$ & $\mathrm{~T}$ & .04 & na & .09 & na & Ad1t-dump ( 150 tons $)-g r a b$ \\
\hline 29 & 400 & - & - & 100 & $\mathrm{~T}$ & .2 & na & na & na & Pit-face-chip-6.5 ft. \\
\hline 30 & 1,500 & - & 1,000 & 100 & $\mathrm{~T}$ & .8 & .02 & .06 & .06 & Shaft-dump ( 75 cons)-grab \\
\hline $31+$ & 3,500 & 2,000 & 1,000 & 100 & .02 & 2.4 & .03 & .15 & .03 & Shaft-stockp1le(100 lb.)-grab \\
\hline $32+$ & 600 & - & - & 100 & $\mathrm{~T}$ & .2 & na & na & na & Adit-portal-veln-chlp-1 ft. \\
\hline 33 & 1,500 & - & - & 100 & $\mathrm{~T}$ & 5.9 & .02 & .07 & na & Shaft-drift-face-vein-chip-3 ft. \\
\hline $34 t$ & 6,000 & 4,000 & - & $<70$ & $\mathrm{~T}$ & 8.8 & .02 & .21 & na & P1t-face-veinlet-ch1p-0.25 ft. \\
\hline $35+$ & 6,000 & - & - & $<70$ & - & 6.7 & .02 & .20 & na & P1t-face-vein-ch $1 \mathrm{p}=2.5 \mathrm{ft}$ \\
\hline 36 & 1,500 & - & - & $<70$ & $\mathrm{~T}$ & .3 & na & .05 & na & Pit-face-fault zone-chip-1.5 ft. \\
\hline $37 \dot{r}$ & 6,000 & $<1,000$ & - & 100 & $\mathrm{~T}$ & 62.1 & .62 & .51 & na & Trench-stockp1le $(50 \mathrm{lb})-,\mathrm{grab}$ \\
\hline 38 & 700 & $\rightarrow$ & - . & 300 & - & .2 & na & na & na & P1t-dump ( 5 tons)-grab \\
\hline 39 & 600 & - & - & 300 & $\mathrm{~T}$ & .2 & na & na & na & Pit-dike-ch1p-2.5 ft. \\
\hline 40 & 200 & - & - & 100 & $\mathrm{~T}$ & .1 & na & na & na & Pit-vein-chip-1 ft. \\
\hline 41 & 100 & - & $\therefore$ & 200 & $\mathrm{~T}$ & .1 & na & na & na & Pit-floor-specimen \\
\hline $42 i$ & 1,000 & - & - & 70 & $: 0.1$ & 7.4 & .05 & .27 & na & Fit-stockp1le(1 ton)-grab \\
\hline 43 & 2,000 & - & - & 70 & - & 2.4 & na & .17 & na & Adit-dump ( 30 tons)-grab \\
\hline 44 & 1,500 & - & - & 70 . & $T$ & .5 & na & .07 & na & Ad1t-dump ( 200 tons)-grab \\
\hline 45 & 6,000 & - & - & 70 & $\mathrm{~T}$ & 1.0 & .01 & .12 & na & Shaft-dump ( 250 tons $)-\mathrm{grab}$ \\
\hline 46 & 3,000 & - & 2,000 & $<70$ & .01 & 3.0 & na & .10 & .10 & Shaft-dump (400 tons)-grab \\
\hline 47 & 3,000 & - & 7,000 & $<70$ & $\mathrm{~T}$ & 2.7 & na & .07 & .12 & Adit-wall-vein-chip-1 ft. \\
\hline 48 & 8,000 & - & 3,000 & $<70$ & .01 & 2.7 & na & .32 & .26 & Adft-face-ch $1 \mathrm{p}-5 \mathrm{ft}$. \\
\hline $49+$ & 20,000 & 1,000 & 30,000 & $<70$ & .07 & 13.6 & .07 & .94 & 1.70 & Adit-face-vein-chip-1.5 ft. \\
\hline $50 \%$ & 10,000 & - & 10,000 & $<70$ & .07 & 14.3 & .07 & .33 & 1.57 & Adit-raise-wall-specimen \\
\hline $51 \div$ & 20,000 & - & 3,000 & $<70$ & $\mathrm{~T}$ & 5.6 & na & .23 & .20 & Ad1t-dump (700 tons)-grab \\
\hline $52 \div$ & 10,000 & - & - & $<70$ & $\mathrm{~T}$ & 2.3 & .14 & .53 & na & Adit-face-vein-chip-3.75 ft. \\
\hline $53+$ & 20,000 & - & 5,000 & $<70$ & - & 5.4 & .24 & .95 & .52 & Ad1t-face-muck-grab \\
\hline 54 & 200 & - & - & 100 & - & - & na & na & na & Outcrop-dike-chip-80 ft. \\
\hline 55 & 100 & - & - & 100 & - & - & na & na & na & Outcrop-dike-ch1p-spectmen \\
\hline 56 & 200 & $<1,000$ & - & 600 & - & - & na & na & na & Pit-floor-grab-5 ft. \\
\hline 57 & 200 & $<1,000$ & - & 600 & - & - & na & no & na & Outcrop (talus)-specimen \\
\hline 58 & 200 & $<1,000$ & - & 600 & - & .2 & na & na & na & Stream-sediment \\
\hline $59 \mathrm{r}$ & 100 & $<1,000$ & - & 100 & - & - & na & na & na & Outcrop(talus)-specimen \\
\hline 60 & 200 & $<1,000$ & - & 100 & - & $\mathrm{T}$ & na & na & na & Outcrop(talus)-grab-30 fe. \\
\hline
\end{tabular}


TABLE 11.-Analyses of samples from study areas

\begin{tabular}{|c|c|c|c|c|c|c|c|c|c|c|c|c|c|}
\hline \multirow[b]{3}{*}{ Sample } & \multirow[b]{3}{*}{$\begin{array}{l}\text { Location } \\
\text { T. R. S. }\end{array}$} & \multicolumn{12}{|c|}{ Semiquantitative spectrographic analyses } \\
\hline & & \multicolumn{6}{|c|}{ percent } & \multicolumn{6}{|c|}{$p p m$} \\
\hline & & $\begin{array}{c}\mathrm{AI} \\
(.003) \\
\end{array}$ & $\begin{array}{c}\mathrm{Ca} \\
(.02) \\
\end{array}$ & $\begin{array}{c}\mathrm{Fe} \\
(.004)\end{array}$ & $\begin{array}{c}\mathrm{Mg} \\
(.004) \\
\end{array}$ & $\begin{array}{c}\mathrm{Mn} \\
(.003) \\
\end{array}$ & $\begin{array}{c}\mathrm{Ti} \\
(.001) \\
\end{array}$ & $\begin{array}{c}B \\
(1.00) \\
\end{array}$ & $\begin{array}{c}\mathrm{Ba} \\
(1,000)\end{array}$ & $\begin{array}{c}\mathrm{Cr} \\
(30)\end{array}$ & $\begin{array}{c}\mathrm{Cu} \\
(20)\end{array}$ & $\begin{array}{c}\text { Mo } \\
(20)\end{array}$ & $\begin{array}{c}\mathrm{NI} \\
(20) \\
\end{array}$ \\
\hline $61 t$ & $44-5-13 *$ & 5.0 & 0.2 & 1.0 & 0.2 & 0.05 & 0.05 & - & - & 60 & 40 & - & - \\
\hline $62+$ & $44-5-13 *$ & M & $>4$ & $>7$ & 3 & .2 & .4 & 100 & 1,000 & 60 & 40 & - & - \\
\hline 63 & $44-4-18 *$ & M & $>4$ & 7 & 1.5 & .4 & .4 & 100 & 2,000 & 60 & 40 & - & - \\
\hline 64 & $44-4-18 *$ & 5 & .5 & 4 & .8 & .1 & .2 & $-\cdots$ & - & 30 & 30 & - & - \\
\hline 65 & $44-4-18 *$ & $M$ & .4 & 7 & 1.5 & .2 & .2 & - & 1,000 & 30 & 30 & - & - \\
\hline 66 & $44-4-7 *$ & $\mathrm{M}$ & .5 & 7 & 1.5 & .2 & .2 & - & 1,000 & - & 20 & - & - \\
\hline 67 & $44-4-5^{\star}$ & M & .5 & 2 & .4 & .4 & .2 & 100 & 2,000 & 60 & 20 & - & - \\
\hline $68 \div$ & $44-4-5^{*}$ & 3 & .3 & .9 & .4 & M & .02 & - & 20,000 & - & 160 & 300 & 70 \\
\hline 69 & $44-4-5 *$ & $M$ & 2 & 5 & .8 & .2 & .2 & - & 1,000 & 200 & 80 & - & - \\
\hline 70 & $44-5-2 *$ & M & .3 & 2 & .2 & .1 & .1 & $<100$ & 1,000 & 60 & 80 & - & - \\
\hline $71 \%$ & $44-5-2 *$ & 5 & .5 & 2 & 1.5 & .05 & .05 & $<100$ & - & 300 & 20 & - & - \\
\hline $72 \div$ & $44-5-2 *$ & $M$ & .3 & 7 & .4 & .4 & .1 & $<100$ & $<1,000$ & 100 & 100 & - & - \\
\hline 73 & $44-5-2 \star$ & 5 & .2 & 3 & .2 & .1 & .05 & $<100$ & $<1,000$ & 60 & 80 & - & - \\
\hline 74 & $44-5-9 *$ & M & .3 & 3 & .4 & .1 & .1 & $<100$ & 5,000 & 100 & 20 & - & - \\
\hline $75 \%$ & $44-5-9 *$ & M & .3 & 2 & .2 & M & .1 & $<100$ & 2,000 & 60 & 40 & 100 & - \\
\hline $76+$ & $44-5-15^{*}$ & $M$ & $M$ & 7 & .8 & .2 & .2 & $<100$ & 2,000 & 100 & 20 & - & - \\
\hline $77+$ & $44-5-15^{\star}$ & $M$ & .2 & 4 & .3 & .2 & .2 & - & - & 30 & 20 & - & - \\
\hline $78 \dagger$ & $44-5-15^{\star}$ & $>5$ & 4 & 4 & .4 & .1 & .2 & - & - & 70 & 60 & - & - \\
\hline $79+$ & $44-5-15 *$ & $\mathbf{M}$ & .3 & 2 & .8 & .1 & .2 & - & $<1,000$ & 100 & 60 & - & - \\
\hline $80 \div$ & $44-5-15^{*}$ & $M$ & .2 & 1 & .4 & .05 & .2 & - & $<1,000$ & 60 & 40 & - & - \\
\hline 81 & $44-5-15^{\star}$ & $>5$ & .5 & 3 & .4 & .1 & .2 & - & 1,000 & 70 & 40 & - & - \\
\hline 82 & $44-5-15 *$ & $>5$ & .5 & 3 & .4 & .1 & .2 & - & 1,000 & 70 & 30 & - & - \\
\hline $83 \div$ & $44-5-22 \star$ & 5 & .2 & 1 & .4 & .05 & .05 & - & - & 60 & 20 & - & - \\
\hline $84 \div$ & $44-5-22 \star$ & M & .3 & 2 & .2 & .1 & .1 & - & - & 60 & 40 & - & - \\
\hline 85 & $44-5-22 *$ & 5 & 4 & 6 & 3 & .1 & .1 & - & - & 60 & 160 & - & - \\
\hline $86+$ & $44-5-22 *$ & $M$ & .3 & 2 & .4 & .1 & .2 & - & 1,000 & 60 & 40 & - & - \\
\hline 87 & $44-5-22 \star$ & .3 & .06 & 4 & .2 & .05 & .02 & - & - & 200 & 80 & - & - \\
\hline 88 & $44-5-27 \star$ & $M$ & 2 & 6 & .4 & .2 & .4 & - & - & 30 & 40 & - & - \\
\hline 89 & $44-5-27 \star$ & 2 & .2 & 6 & .4 & .1 & .1 & - & - & 60 & 40 & - & - \\
\hline 90 & $44-5-25^{\star}$ & 4 & .5 & .4 & .1 & .1 & .1 & - & - & - & 20 & - & - \\
\hline 91 & $44-5-25^{\star}$ & .3 & M & .2 & .1 & .4 & .01 & - & - & - & $<20$ & - & - \\
\hline 92 & $44-5-25 *$ & 2 & $M$ & .4 & .1 & .2 & .1 & - & - & - & $<20$ & - & - \\
\hline 93 & $44-5-25 *$ & .2 & M & .2 & .1 & .4 & .003 & - & - & - & $<20$ & - & - \\
\hline 94 & $44-5-25 *$ & 5 & $>4$ & .6 & .2 & .2 & .01 & - & - & 30 & 30 & - & - \\
\hline 95 & $44-5-25 *$ & 2 & M & 1 & .1 & .2 & .05 & - & - & - & 30 & - & - \\
\hline 96 & $44-5-25^{\star}$ & 1 & 1 & 1 & .1 & .2 & .02 & - & - & 60 & 40 & - & - \\
\hline 97 & $44-5-25 *$ & $M$ & .5 & 4 & .8 & .2 & .2 & - & 1,000 & 200 & 80 & - & - \\
\hline $98+$ & $44-5-26^{\star}$ & M & .3 & 4 & .8 & .2 & .2 & 100 & 1,000 & 200 & 3,000 & - & - \\
\hline 99 & $44-5-26 *$ & .2 & M & .3 & .2 & .2 & .003 & - & - & - & 30 & $<20$ & - \\
\hline 100 & $44-5-34 *$ & 3 & .06 & 3 & .1 & .05 & .1 & - & - & 60 & 20 & $<20$ & - \\
\hline $101 \%$ & $44-5-33^{*}$ & 1 & - & 3 & .05 & .02 & .02 & 100 & - & 30 & 3,000 & 30 & - \\
\hline 102 & $44-5-33^{*}$ & 3 & .03 & 3 & .1 & .2 & .05 & 200 & - & 60 & 600 & 20 & - \\
\hline $103 i$ & $44-6-36 \star$ & $M$ & .03 & 6 & .4 & .05 & .05 & 100 & 1,000 & 100 & 10,000 & 30 & - \\
\hline $104 \%$ & $44-6-36 *$ & 5 & .03 & 4 & .1 & .05 & .05 & 100 & - & 100 & 5,000 & 30 & - \\
\hline 105 & $44-6-36^{\star}$ & $M$ & .2 & 3 & .4 & .05 & .05 & 100 & $<1,000$ & 100 & 10,000 & 70 & - \\
\hline $106 \div$ & $44-6-36^{\star}$ & 1 & - & 3 & .1 & .05 & .01 & - & - & 100 & 30,000 & 200 & - \\
\hline 107 & $44-6-36^{\star}$ & $M$ & .06 & 3 & .4 & .1 & .1 & 100 & $<1,000$ & 100 & 5,000 & 40 & - \\
\hline 108 & $44-6-36 \star$ & $M$ & .03 & 2 & .4 & .05 & .1 & $<100$ & - & 100 & 5,000 & 30 & - \\
\hline 109 & $44-6-36^{\star}$ & 2 & .06 & 5 & .2 & .05 & .1 & - & - & 60 & 600 & 20 & - \\
\hline 110 & $44-6-25 *$ & 4 & .06 & 2 & .2 & .05 & .05 & - & - & 60 & 40 & - & - \\
\hline 111 & $44-6-26 *$ & $M$ & .1 & 3 & .4 & .1 & .2 & 200 & 1,000 & 60 & 40 & $<20$ & - \\
\hline 112 & $44-6-26 *$ & $M$ & .1 & 3 & .4 & .03 & .2 & 200 & 1,000 & 60 & 20 & $<20$ & - \\
\hline 113 & $44-6-26 *$ & $M$ & .06 & 3 & .4 & .2 & .2 & - & 2,000 & 60 & 40 & - & - \\
\hline 114 & $44-6-27 *$ & $>5$ & .3 & 2 & .2 & .1 & .05 & - & - & 70 & 30 & - & - \\
\hline $115+$ & $44-6-27^{\star}$ & $>5$ & .3 & 2 & .2 & .1 & .05 & - & - & 70 & 30 & - & - \\
\hline 116 & $44-5-20 *$ & M & .2 & 1 & .1 & .05 & .2 & - & - & 60 & 20 & 20 & - \\
\hline $117 \%$ & $44-5-20 *$ & 4 & .1 & .6 & .02 & .02 & .2 & - & - & - & 20 & - & - \\
\hline 118 & $44-5-17 *$ & $M$ & 4 & 7 & 1.5 & .2 & .4 & $<100$ & 2,000 & 300 & 80 & - & - \\
\hline 119 & $44-5-17 *$ & M & 4 & 6 & 1.5 & .2 & .4 & $<100$ & $<1,000$ & 100 & 40 & - & - \\
\hline $120 \%$ & $44-5-17 \star$ & $M$ & $M$ & $>7$ & 1.5 & .2 & 1 & $<100$ & $<1,000$ & 300 & 80 & - & - \\
\hline
\end{tabular}


CONTIGUOUS AREAS, UNCOMPAHGRE PRIMITIVE AREA, COLO. E111. contiguous to the Uncompahgre Primitive Area-Continued

\begin{tabular}{|c|c|c|c|c|c|c|c|c|c|c|}
\hline \multirow[b]{3}{*}{ Sample } & \multicolumn{4}{|c|}{$\begin{array}{l}\text { Semiquantitative spectrographic } \\
\text { analyses--Continued }\end{array}$} & \multirow{2}{*}{\multicolumn{2}{|c|}{$\frac{\text { Fire assay }}{0 z / \text { ton }}$}} & \multirow{2}{*}{\multicolumn{3}{|c|}{$\begin{array}{c}\begin{array}{c}\text { Atomic absorption } \\
\text { analyses }\end{array} \\
\text { percent }\end{array}$}} & \multirow{3}{*}{ Sample data } \\
\hline & \multicolumn{4}{|c|}{$\mathrm{ppm}$} & & & & & & \\
\hline & $\begin{array}{c}\mathrm{Pb} \\
(100)\end{array}$ & $\begin{array}{c}\mathrm{Sr} \\
(1,000)\end{array}$ & $\begin{array}{c}2 \mathrm{n} \\
(1,000) \\
\end{array}$ & $\begin{array}{c}\mathrm{Zr} \\
(70) \\
\end{array}$ & $\mathrm{Au}$ & $\mathrm{Ag}$ & $\overline{\mathrm{Cu}}$ & $\mathrm{Pb}$ & $2 n$ & \\
\hline $\begin{array}{l}61 \% \\
62+ \\
63 \\
64 \\
65\end{array}$ & $\begin{array}{r}600 \\
1,000 \\
-\quad 200 \\
100\end{array}$ & $\begin{array}{l}<1,000 \\
<1,000 \\
<1,000 \\
<1,000\end{array}$ & $\begin{array}{l}- \\
- \\
- \\
-\end{array}$ & $\begin{array}{l}<70 \\
300 \\
600 \\
100 \\
100\end{array}$ & $\begin{array}{l}\mathrm{T} \\
\overline{-} \\
\overline{-} \\
-\end{array}$ & $\begin{array}{r}0.2 \\
.2 \\
- \\
- \\
-\end{array}$ & $\begin{array}{l}\text { na } \\
\text { na } \\
\text { na } \\
\text { na } \\
\text { na }\end{array}$ & $\begin{array}{l}\text { na } \\
0.02 \\
\text { na } \\
\text { na } \\
\text { na }\end{array}$ & $\begin{array}{l}\text { na } \\
\text { na } \\
\text { na } \\
\text { na } \\
\text { na }\end{array}$ & $\begin{array}{l}\text { Trench-wall-ch1p-1 ft. } \\
\text { P1t-floor-specimen } \\
\text { Outcrop-ch1p-specimen } \\
\text { Trench-floor-ch1p-4 ft. } \\
\text { Trench-wall-ch1p-2 ft. }\end{array}$ \\
\hline $\begin{array}{l}66 \\
67 \\
68+ \\
69 \\
70\end{array}$ & $\begin{array}{r}100 \\
200 \\
-\quad \\
100 \\
200\end{array}$ & $\begin{array}{l}<1,000 \\
\overline{1,000} \\
-\end{array}$ & $\begin{array}{l}- \\
- \\
- \\
-\end{array}$ & $\begin{array}{c}300 \\
<70 \\
300 \\
- \\
<70\end{array}$ & $\begin{array}{l}- \\
- \\
- \\
-\end{array}$ & $\begin{array}{l}- \\
- \\
- \\
.2\end{array}$ & $\begin{array}{c}\text { na } \\
\text { na } \\
0.03 \\
\text { na } \\
\text { na }\end{array}$ & $\begin{array}{l}\text { na } \\
\text { na } \\
\text { na } \\
\text { na } \\
\text { na }\end{array}$ & $\begin{array}{l}\text { na } \\
\text { na } \\
\text { na } \\
\text { na } \\
\text { na }\end{array}$ & $\begin{array}{l}\text { Outcrop-chip-3 ft. } \\
\text { Outcrop-ch1p-specimen } \\
\text { Trench-wall-chip-10 ft. } \\
\text { Trench-floor-grab-10 ft. } \\
\text { Outcrop-dike-chip-specimen }\end{array}$ \\
\hline $\begin{array}{l}71 \% \\
72 \% \\
73 \\
74 \\
75 \%\end{array}$ & $\begin{array}{r}200 \\
3,000 \\
200 \\
100 \\
100\end{array}$ & $\begin{array}{l}- \\
- \\
-\end{array}$ & $\begin{array}{l}- \\
- \\
- \\
-\end{array}$ & $\begin{array}{l}<70 \\
<70 \\
<70 \\
<70 \\
<70\end{array}$ & $\begin{array}{l}\mathrm{T} \\
\mathrm{T} \\
\mathrm{T} \\
\mathrm{T} \\
-\end{array}$ & $\begin{array}{l}- \\
.1 \\
.1 \\
.1 \\
.1\end{array}$ & $\begin{array}{l}\text { na } \\
\text { na } \\
\text { na } \\
\text { na } \\
\text { na }\end{array}$ & $\begin{array}{l}.04 \\
\text { na } \\
\text { na } \\
\text { na }\end{array}$ & $\begin{array}{l}\text { na } \\
\text { na } \\
\text { na } \\
\text { na } \\
\text { na }\end{array}$ & $\begin{array}{l}\text { Outcrop(talus)-specimen } \\
\text { Do. } \\
\text { Do. } \\
\text { Do. } \\
\text { Pit-vein-chip-1 ft. }\end{array}$ \\
\hline $\begin{array}{l}76+ \\
77+ \\
78+ \\
79+ \\
80+\end{array}$ & $\begin{array}{l}100 \\
700 \\
100 \\
700 \\
200\end{array}$ & $\begin{array}{l}<1,000 \\
- \\
- \\
- \\
-\end{array}$ & $\begin{array}{l}- \\
- \\
- \\
-\end{array}$ & $\begin{array}{l}<70 \\
<70 \\
<70 \\
<70 \\
<70\end{array}$ & $\begin{array}{ll} & - \\
\mathrm{T} & \mathrm{T} \\
\mathrm{T} & \mathrm{T}\end{array}$ & $\mathrm{T}_{.1}^{.1} .1$ & $\begin{array}{l}\text { na } \\
\text { na } \\
\text { na } \\
\text { na } \\
\text { na }\end{array}$ & $\begin{array}{l}\text { na } \\
\text { na } \\
\text { na } \\
\text { na } \\
\text { na }\end{array}$ & $\begin{array}{l}\text { na } \\
\text { na } \\
\text { na } \\
\text { na } \\
\text { na }\end{array}$ & $\begin{array}{l}\text { Outcrop-ch1p-specimen } \\
\text { Outcrop-chip-100 ft. } \\
\text { Outcrop-chip-6 ft. } \\
\text { Outcrop-ch } 1 \text { p-1 ft. } \\
\text { Outcrop-ch } 1 \mathrm{p}-10 \mathrm{ft} \text {. }\end{array}$ \\
\hline $\begin{array}{l}81 \\
82 \\
83 \dagger \\
84 \div \\
85\end{array}$ & $\begin{array}{l}100 \\
100 \\
200 \\
200 \\
100\end{array}$ & $\begin{array}{l}- \\
- \\
- \\
-\end{array}$ & $\begin{array}{l}- \\
- \\
- \\
-\end{array}$ & $\begin{array}{r}100 \\
100 \\
<70 \\
70 \\
70\end{array}$ & $\begin{array}{l}\mathrm{T} \\
\mathrm{T} \\
\mathrm{T} \\
-\end{array}$ & $\stackrel{.1}{\mathrm{~T}^{-3}}$ & $\begin{array}{l}\text { na } \\
\text { na } \\
\text { na } \\
\text { na } \\
.01\end{array}$ & $\begin{array}{l}\text { na } \\
\text { na } \\
\text { na } \\
\text { na } \\
\text { na }\end{array}$ & $\begin{array}{l}\text { na } \\
\text { na } \\
\text { na } \\
\text { na } \\
\text { na }\end{array}$ & $\begin{array}{l}\text { Trench-floor--grab-50 ft. } \\
\text { Trench-floor-grab-100 ft. } \\
\text { Outcrop(talus)-specimen } \\
\text { Do. } \\
\text { Do. }\end{array}$ \\
\hline $\begin{array}{l}86 \dagger \\
87 \\
88 \\
89 \\
90\end{array}$ & $\begin{array}{r}200 \\
-\quad 400 \\
-\end{array}$ & $\begin{array}{l}- \\
- \\
-\end{array}$ & $\begin{array}{l}- \\
- \\
- \\
-\end{array}$ & $\begin{array}{l}100 \\
- \\
<70 \\
<70 \\
<70\end{array}$ & $\begin{array}{l}- \\
T^{-} \\
-\end{array}$ & $\begin{array}{l}- \\
. \\
.1 \\
.2 \\
-\end{array}$ & $\begin{array}{l}\text { na } \\
\text { na } \\
\text { na } \\
\text { na } \\
\text { na }\end{array}$ & $\begin{array}{l}\text { na } \\
\text { na } \\
\text { na } \\
\text { na } \\
\text { na }\end{array}$ & $\begin{array}{l}\text { na } \\
\text { na } \\
\text { na } \\
\text { na } \\
\text { na }\end{array}$ & $\begin{array}{l}\text { Do. } \\
\text { Do. } \\
\text { Outcrop-d1ke-chip-specimen } \\
\text { Outcrop-dike-chip-1 ft. } \\
\text { P1t-vein-ch1p-1.5 ft. }\end{array}$ \\
\hline $\begin{array}{l}91 \\
92 \\
93 \\
94 \\
95\end{array}$ & $\begin{array}{r}100 \\
<100 \\
100 \\
<100 \\
-\end{array}$ & $\begin{array}{l}- \\
- \\
-\end{array}$ & $\begin{array}{l}- \\
- \\
- \\
-\end{array}$ & $\begin{array}{l}<70 \\
<70 \\
<70 \\
<70 \\
<70\end{array}$ & $\begin{array}{l}\mathrm{T} \\
\mathrm{T} \\
\mathrm{T} \\
\mathrm{T} \\
\mathrm{T}\end{array}$ & $\begin{array}{l}\overline{-} \\
\overline{-} \\
\overline{.01}\end{array}$ & $\begin{array}{l}\text { na } \\
\text { na } \\
\text { na } \\
\text { na } \\
\text { na }\end{array}$ & $\begin{array}{l}\text { na } \\
\text { na } \\
\text { na } \\
\text { na } \\
\text { na }\end{array}$ & $\begin{array}{l}\text { na } \\
\text { na } \\
\text { na } \\
\text { na } \\
\text { na }\end{array}$ & $\begin{array}{l}\text { Pit-vein-chip-0.5 ft. } \\
\text { Pit-vein-chip-3 ft. } \\
\text { Pit-floor-specimen } \\
\text { Pit-vein-chip-6 ft. } \\
\text { Pit-floor-specimen }\end{array}$ \\
\hline $\begin{array}{l}96 \\
97 \\
98 \div \\
99 \\
100\end{array}$ & $\begin{array}{r}- \\
100 \\
1,500 \\
100 \\
400\end{array}$ & $\begin{array}{l}- \\
- \\
-\end{array}$ & $\begin{array}{l}- \\
- \\
- \\
-\end{array}$ & $\begin{array}{r}<70 \\
70 \\
70 \\
<70 \\
<70\end{array}$ & $\mathrm{~T}_{\mathrm{T}}^{\mathrm{T}}$ & $\begin{array}{l}.01 \\
\overline{9} \\
\overline{1}\end{array}$ & $\begin{array}{l}\text { na } \\
\text { na } \\
.20 \\
\text { na } \\
\text { na }\end{array}$ & $\begin{array}{l}\text { na } \\
\text { na } \\
\text { na } \\
\text { na }\end{array}$ & $\begin{array}{l}\text { na } \\
\text { na } \\
\text { na } \\
\text { na } \\
\text { na }\end{array}$ & $\begin{array}{l}\text { Do. } \\
\text { Pit-dump ( } 3 \text { tons)-grab } \\
\text { P1t-vein-chip-1.85 ft. } \\
\text { Pit-stockp } 1 \text { le (10 tons)-grab } \\
\text { Stream-grab-specimen }\end{array}$ \\
\hline $\begin{array}{l}101 \dagger \\
102 \\
103 t \\
104 t \\
105\end{array}$ & $\begin{array}{r}80,000 \\
30,000 \\
50,000 \\
100,000 \\
60,000\end{array}$ & $\begin{array}{l}- \\
- \\
- \\
-\end{array}$ & $\begin{array}{r}10,000 \\
1,000 \\
5,000 \\
40,000 \\
30,000\end{array}$ & $\begin{array}{l}<70 \\
<70 \\
<70 \\
<70 \\
<70\end{array}$ & $\begin{array}{r}.02 \\
.02 \\
.01 \\
.01\end{array}$ & $\begin{array}{l}9.8 \\
1.4 \\
5.9 \\
2.5 \\
2.5\end{array}$ & $\begin{array}{r}.41 \\
.05 \\
.42 \\
1.01 \\
.49\end{array}$ & $\begin{array}{r}4.15 \\
.99 \\
1.48 \\
3.20 \\
5.32\end{array}$ & $\begin{array}{r}2.22 \\
.19 \\
.32 \\
3.74 \\
3.22\end{array}$ & $\begin{array}{l}\text { Adit-dump ( } 4,000 \text { tons })-g r a b \\
\text { Ad1t-portal-ve1n-ch1p-7 ft. } \\
\text { Shaft-dump }(1,000 \text { tons })-g r a b \\
\text { Ad1t-back vein-chip-1.25 ft. } \\
\text { Ad1t-dump ( } 400 \text { tons)-grab }\end{array}$ \\
\hline $\begin{array}{l}106+ \\
107 \\
108 \\
109 \\
110 \dagger\end{array}$ & $\begin{array}{l}M \\
60,000 \\
60,000 \\
20,000 \\
200\end{array}$ & $\begin{array}{l}- \\
- \\
-\end{array}$ & $\begin{array}{l}80,000 \\
20,000 \\
20,000 \\
3,000 \\
=\end{array}$ & $\begin{array}{l}<70 \\
<70 \\
<70 \\
<70 \\
<60\end{array}$ & $\mathrm{~T}_{-}^{.05}$ & $\begin{array}{r}11.6 \\
1.4 \\
1.6 \\
1.6 \\
.2\end{array}$ & $\begin{array}{r}1.74 \\
.32 \\
.35 \\
.13 \\
\text { na }\end{array}$ & $\begin{array}{l}19.0 \\
2.16 \\
3.02 \\
1.85 \\
\text { na }\end{array}$ & $\begin{array}{l}4.56 \\
2.00 \\
1.60 \\
.32 \\
\text { na }\end{array}$ & $\begin{array}{l}\text { Adit-s tope-vein-chip-2 ft. } \\
\text { Adit-dump ( } 800 \text { tons) }-g r a b \\
\text { Shaft-dump ( } 500 \text { tons) }-\mathrm{grab} \\
\text { Adit-face-vein-ch1p-3 ft. } \\
\text { Trench-wall-ch } 1 \mathrm{p}-100 \mathrm{ft} \text {. }\end{array}$ \\
\hline $\begin{array}{l}111 \\
112 \\
113 \\
114 \\
115+\end{array}$ & $\begin{array}{l}500 \\
600 \\
200 \\
100 \\
100\end{array}$ & $\begin{array}{l}- \\
- \\
-\end{array}$ & $\begin{array}{l}- \\
- \\
-\end{array}$ & $\begin{array}{r}300 \\
100 \\
100 \\
70 \\
70\end{array}$ & $\begin{array}{l}\mathrm{T} \\
\mathrm{T} \\
\mathrm{T} \\
\mathrm{T} \\
\mathrm{T}\end{array}$ & $\begin{array}{r}.2 \\
.2 \\
.1 \\
.1\end{array}$ & $\begin{array}{l}\text { na } \\
\text { na } \\
\text { na } \\
\text { na } \\
\text { na }\end{array}$ & $\begin{array}{l}\text { na } \\
\text { na } \\
\text { na } \\
\text { na } \\
\text { na }\end{array}$ & $\begin{array}{l}\text { na } \\
\text { na } \\
\text { na } \\
\text { na } \\
\text { na }\end{array}$ & $\begin{array}{l}\text { Trench-wall-chip-50 ft. } \\
\text { Trench-wall-chip-6 ft. } \\
\text { Outcrop-d1ke-chip-9 ft. } \\
\text { Pft-floor-specimen } \\
\text { Do. }\end{array}$ \\
\hline $\begin{array}{l}116 \\
117+ \\
118 \\
119 \\
120+\end{array}$ & $\begin{array}{r}100 \\
1,500 \\
100 \\
100 \\
100\end{array}$ & $\begin{array}{l}- \\
- \\
- \\
-\end{array}$ & $\begin{array}{l}- \\
- \\
- \\
-\end{array}$ & $\begin{array}{l}<70 \\
<70 \\
<70 \\
<70 \\
<70\end{array}$ & $T^{-}$ & $\begin{array}{l}\mathrm{T} \\
.1 \\
.2 \\
.2 \\
-\end{array}$ & $\begin{array}{l}\text { na } \\
\text { na } \\
\text { na } \\
\text { na } \\
\text { na }\end{array}$ & $\begin{array}{l}\text { na } \\
\text { na } \\
\text { na } \\
\text { na }\end{array}$ & $\begin{array}{l}\text { na } \\
\text { na } \\
\text { na } \\
\text { na } \\
\text { na }\end{array}$ & $\begin{array}{l}\text { Trench-floor-specimen } \\
\text { Adit-portal-floor-specimen } \\
\text { Outcrop(talus)-specimen } \\
\text { Do. } \\
\text { Do. }\end{array}$ \\
\hline
\end{tabular}


TABLE 11.-Analyses of samples from study areas

\begin{tabular}{|c|c|c|c|c|c|c|c|c|c|c|c|c|c|}
\hline \multirow[b]{3}{*}{ Sample } & \multirow[b]{3}{*}{$\begin{array}{l}\text { Location } \\
\text { T. R. S. }\end{array}$} & \multicolumn{12}{|c|}{ Semiquantitative spectrographic analyses } \\
\hline & & \multicolumn{6}{|c|}{ percent } & \multicolumn{6}{|c|}{$\mathrm{ppm}$} \\
\hline & & $\begin{array}{c}\mathrm{A} 1 \\
(.003) \\
\end{array}$ & $\begin{array}{r}\mathrm{Ca} \\
(.02) \\
\end{array}$ & $\begin{array}{c}\mathrm{Fe} \\
(.004) \\
\end{array}$ & $\begin{array}{c}\mathrm{Mg} \\
(.004) \\
\end{array}$ & $\begin{array}{c}\mathrm{Mn} \\
(.003) \\
\end{array}$ & $\begin{array}{c}\mathrm{T} 1 \\
(.001) \\
\end{array}$ & $\begin{array}{c}B \\
(100) \\
\end{array}$ & $\begin{array}{c}\mathrm{Ba} \\
(1,000)\end{array}$ & $\begin{array}{c}\mathrm{Cr} \\
(30)\end{array}$ & $\begin{array}{c}\mathrm{Cu} \\
(20) \\
\end{array}$ & $\begin{array}{c}\text { Mo } \\
(20)\end{array}$ & $\begin{array}{c}\mathrm{Ni} \\
(20) \\
\end{array}$ \\
\hline 121 & $44-6-15 *$ & $>5.0$ & 0.06 & 1.0 & 0.05 & 0.006 & 0.2 & - & - & 100 & 40 & 60 & - \\
\hline 122 & $44-6-15 *$ & $>5$ & .1 & 5 & 2 & .05 & .2 & - & - & 100 & 40 & $<20$ & - \\
\hline 123 & $44-6-15 *$ & $>5$ & .06 & 4 & .8 & .03 & .4 & $<100$ & - & 100 & 100 & $<20$ & - \\
\hline 124 & $44-6-15 *$ & $>5$ & .07 & 5 & .8 & .03 & .4 & $<100$ & - & 100 & 100 & $<20$ & - \\
\hline 125 & $44-6-10 *$ & $>5$ & .03 & 5 & 2 & .05 & .2 & - & - & 100 & 40 & $<20$ & - \\
\hline 126 & $44-6-10 *$ & $>5$ & .1 & 4 & .8 & .05 & .4 & - & - & 100 & 60 & $<20$ & - \\
\hline 127 & $44-6-10 *$ & $>5$ & .03 & 3 & .2 & .03 & .4 & - & - & 100 & 40 & $<20$ & - \\
\hline 128 & $44-6-10^{*}$ & $>5$ & 4 & 4 & .8 & 1 & .2 & - & - & 300 & 600 & - & - \\
\hline $129 t$ & $44-6-10 *$ & 4 & .03 & 1 & $<.004$ & .01 & .1 & 100 & - & 100 & 40 & - & - \\
\hline $130 t$ & $44-6-10 *$ & 1 & .03 & 4 & $<.004$ & .03 & .2 & - & 4,000 & 500 & 80 & $<20$ & - \\
\hline $131 \%$ & $44-6-1 *$ & 2 & .5 & $M$ & .4 & .4 & 6 & - & - & 300 & 80 & - & - \\
\hline $132 \div$ & $44-6-1 *$ & 3 & .5 & $M$ & .4 & .4 & 3 & - & - & 300 & 60 & - & - \\
\hline 133 & $44-6-1^{*}$ & M & .3 & 5 & 1.5 & .05 & .2 & - & $<1,000$ & 100 & 40 & - & - \\
\hline 134 & 44- 6- 1* & M & .3 & 4 & 1.5 & .05 & .2 & - & $<1,000$ & 60 & 80 & - & - \\
\hline 135 & $44-6-1 *$ & 5 & .3 & 4 & .8 & .1 & .4 & - & - & 100 & 40 & - & - \\
\hline $136 \dagger$ & $44-6-1 *$ & $>5$ & 2 & 4 & .8 & .2 & .4 & - & - & 100 & 60 & $<20$ & - \\
\hline 137 & $44-6-1 *$ & $>5$ & 1 & 5 & 2 & .2 & .4 & - & - & 100 & 60 & $<20$ & - \\
\hline 138 & $45-6-36 *$ & 5 & .1 & 2 & .8 & .02 & .2 & - & - & 60 & 40 & 30 & - \\
\hline 139 & $45-6-36 \star$ & 2 & .3 & .4 & .1 & .4 & .1 & - & - & 100 & 40 & $<20$ & - \\
\hline 140 & $45-6-36 \star$ & $>5$ & .3 & 2 & .2 & .4 & .2 & - & - & 100 & 60 & $<20$ & - \\
\hline 141 & $45-6-36 \star$ & $>5$ & .5 & 4 & 3 & .2 & .4 & - & - & 100 & 60 & $<20$ & - \\
\hline 142 & $45-6-36 \star$ & $>5$ & .5 & 4 & 3 & .2 & .4 & - & - & 100 & 60 & $<20$ & - \\
\hline 143 & $45-6-36 *$ & $>5$ & 2 & 4 & .8 & .1 & .4 & - & - & 100 & 40 & - & - \\
\hline 144 & $45-6-36 \star$ & 5 & .06 & 4 & .8 & .05 & .2 & - & - & 100 & 40 & 30 & - \\
\hline 145 & $45-6-36^{\star}$ & M & .1 & 4 & 1.5 & .2 & .2 & - & $1,00 \mathrm{C}$ & 200 & 40 & 30 & - \\
\hline 146 & $45-6-35 *$ & $M$ & .3 & 4 & 1.5 & .05 & .2 & - & 1,000 & 200 & 100 & 30 & - \\
\hline 147 & $45-6-35 *$ & M & .2 & 3 & .8 & .02 & .2 & - & 1,000 & 100 & 80 & 30 & - \\
\hline 148 & $45-6-26 *$ & 5 & .5 & 6 & .8 & .02 & .2 & - & - & 100 & 80 & 30 & - \\
\hline $149+$ & $45-6-26 \star$ & 2 & .1 & M & .4 & .2 & .8 & - & - & 300 & 60 & - & - \\
\hline 150 & $45-6-34^{\star}$ & 3 & - & .2 & .006 & .006 & .1 & - & - & - & 20 & 20 & - \\
\hline 151 & $45-6-34 *$ & $>5$ & .1 & 4 & .6 & .4 & .2 & $<100$ & 2,000 & - & 40 & - & - \\
\hline 152 & $45-6-34 *$ & $>5$ & 1 & 4 & 2 & .2 & .2 & - & - & 100 & 40 & - & - \\
\hline 153 & $45-6-34 \star$ & 5 & $>4$ & 4 & .8 & .2 & .2 & - & 2,000 & - & 40 & - & - \\
\hline 154 & $45-6-34^{\star}$ & 5 & 4 & 4 & .8 & .2 & .2 & - & - & - & 60 & - & - \\
\hline 155 & $45-6-34^{\star}$ & 5 & .25 & 4 & .6 & .05 & .2 & $<100$ & - & - & 40 & - & - \\
\hline $156^{+}$ & $45-6-34 *$ & M & 1 & 5 & 1.5 & .1 & .4 & 100 & 1,000 & 60 & 40 & $<20$ & - \\
\hline 157 & $45-7-22 \star$ & 4 & .5 & 2 & .4 & .05 & .1 & - & - & 100 & 20 & - & - \\
\hline 158 & $45-7-21$ & 3 & .5 & .9 & .2 & .03 & .05 & - & - & $<30$ & 10 & - & - \\
\hline 159 & $45-7-21$ & 4 & .5 & 2 & .4 & .05 & .1 & - & - & 100 & 200 & - & - \\
\hline $160^{\circ}$ & $44-7-3 *$ & 1 & M & - & 2 & 2 & .09 & - & M & 500 & 300 & - & 40 \\
\hline 161 & $44-7-3 *$ & .2 & M & 2 & .1 & .05 & .006 & - & - & 100 & 20 & - & 20 \\
\hline 162 & $44-7-3 *$ & .7 & 1 & 1 & .8 & - & .02 & - & 4,000 & 300 & 40 & 30 & 40 \\
\hline 163 & $44-7-3 *$ & 3 & M & .5 & .8 & 2 & .1 & - & - & 60 & 20 & - & 20 \\
\hline 164 & $44-7-3 *$ & 3 & M & 1 & .1 & .03 & .1 & - & - & 60 & $<20$ & - & - \\
\hline $165^{\dagger}$ & $44-7-3^{*}$ & $>5$ & .3 & - & .2 & .4 & .4 & - & 20,000 & 50 & 300 & - & 40 \\
\hline $166 t^{+}$ & $44-7-3 *$ & M & M & - & 3 & .4 & .4 & - & - & 30 & 200 & - & - \\
\hline 167 & $44-7-3^{*}$ & 5 & M & - & 3 & 3 & .2 & - & - & 500 & 300 & - & 40 \\
\hline $168 \dagger$ & $44-7-3 *$ & .1 & .3 & - & .2 & 2 & .01 & - & - & 300 & 300 & - & 40 \\
\hline 169 & $44-7-3 *$ & $>5$ & .4 & - & 3 & 2 & .2 & - & - & 300 & 100 & - & 40 \\
\hline 170 & $44-7-2^{\star}$ & 5 & M & - & 2 & .2 & .2 & - & - & 100 & 100 & - & - \\
\hline 171 & $44-7-2 \star$ & $>5$ & .5 & - & .2 & .4 & .2 & - & - & 200 & 100 & - & - \\
\hline 172 & $44-7-2 *$ & $>5$ & .4 & - & 2 & .4 & .3 & - & - & 200 & 200 & - & - \\
\hline 173 & $44-7-10 *$ & 5 & .06 & 2 & .1 & .05 & .05 & - & $<1,000$ & 70 & 30 & - & - \\
\hline 174 & $44-7-10 *$ & 4 & - & 2 & .02 & .03 & .05 & - & 4,000 & 100 & 40 & - & - \\
\hline 175 & $44-7-15 *$ & 2 & .03 & 1 & .07 & .02 & .2 & - & - & 60 & 30 & - & - \\
\hline 176 & $44-7-15^{\star}$ & M & .06 & 1 & .1 & .02 & .2 & - & - & 30 & 20 & - & - \\
\hline 177 & $44-7-15^{\star}$ & 3 & - & .5 & .01 & .02 & .2 & - & $<1,000$ & 60 & 40 & - & - \\
\hline 178 & $44-7-14 *$ & $>5$ & .5 & 3 & .8 & .05 & .1 & - & - & 200 & 40 & - & - \\
\hline 179 & $44-7-1.3 *$ & 5 & .1 & 2 & .1 & .02 & .05 & - & - & 30 & 40 & - & - \\
\hline 180 & $44-7-24 \star$ & M & .1 & 2 & .2 & .05 & .1 & - & 4,000 & 30 & 40 & - & - \\
\hline
\end{tabular}


contiguous to the Uncompahgre Primitive Area-Continued

\begin{tabular}{|c|c|c|c|c|c|c|c|c|c|c|}
\hline \multirow[b]{3}{*}{ Sample } & \multicolumn{4}{|c|}{$\begin{array}{c}\text { Semiquantitative spectrographic } \\
\text { analyses--Continued }\end{array}$} & \multirow{2}{*}{\multicolumn{2}{|c|}{$\frac{\text { Fire assay }}{\text { oz/ton }}$}} & \multicolumn{3}{|c|}{$\begin{array}{c}\text { Atonic absorption } \\
\text { analyses }\end{array}$} & \multirow{3}{*}{ Sample data } \\
\hline & \multicolumn{4}{|c|}{$\mathrm{ppm}$} & & & \multicolumn{3}{|c|}{ percent } & \\
\hline & $\begin{array}{c}\mathrm{Pb} \\
(100)\end{array}$ & $\begin{array}{c}\mathrm{Sr} \\
(1,000)\end{array}$ & $\begin{array}{c}2 \mathrm{Zn} \\
(1,000) \\
\end{array}$ & $\begin{array}{c}\mathrm{Zr} \\
(70)\end{array}$ & $\mathrm{Au}$ & $\mathrm{Ag}$ & $\mathrm{Cu}$ & $\mathrm{Pb}$ & $2 n$ & \\
\hline 121 & 500 & - & - & 100 & - & - & na & na & na & Trench-wall-ch1p-16 ft. \\
\hline 122 & 400 & - & - & 200 & - & - & na & na & na & Trench-floor-grab-100 ft. \\
\hline 123 & 400 & $<1,000$ & - & 100 & - & 0.1 & na & na & na & Trench-wall-chip-24 ft. \\
\hline 124 & 100 & - & - & 100 & $\mathbf{T}$ & - & na & na & na & Trench-floor-specimen \\
\hline 125 & 100 & - & - & 100 & $\mathrm{~T}$ & $\mathrm{~T}$ & na & na & na & Outcrop-ch1p-16 ft. \\
\hline 126 & 100 & - & - & 100 & - & .1 & na & na & na & Shaft-veln-chip-4 ft. \\
\hline 127 & 700 & 1,000 & - & 300 & $\mathrm{~T}$ & .1 & na & na & na & Pit-wall-chip-6 ft. \\
\hline 128 & 400 & $<1,000$ & - & 100 & $\mathbf{T}$ & - & 0.05 & na & na & Outcrop (talus)-specimen \\
\hline $129+$ & 700 & $<1,000$ & - & 70 & 0.02 & 1.2 & na & na & na & P1t-wa1l-ch1p-3 ft. \\
\hline $130+$ & 700 & 1,000 & - & 70 & .04 & 9.6 & na & na & na & P1t-vein-ch1p-2 in. \\
\hline $131 \div$ & 200 & - & - & 300 & - & - & na & na & na & Stream-panned concentrate \\
\hline $132+$ & 200 & - & - & 1,000 & - & - & na & na & na & Do. \\
\hline 133 & 100 & - & - & 100 & $\mathrm{~T}$ & $\mathrm{~T}$ & na & na & na & Outcrop-d1ke-ch1p-2 ft. \\
\hline 134 & 100 & - & - & 100 & $\mathrm{~T}$ & .1 & na & na & na & Do. \\
\hline 135 & 400 & - & - & 100 & - & .2 & na & na & na & Pit-face-chip-7 ft. \\
\hline $136 \div$ & 100 & - & - & 100 & - & - & na & na & na & Adft-dump ( 700 tons) - grab \\
\hline 137 & 400 & - & - & 100 & $\mathrm{~T}$ & - & na & na & na & Ad1t-ve1n-chip-6 ft. \\
\hline 138 & 400 & - & - & 70 & .09 & .2 & na & na & na & Pit-dump (25 tons)-grab \\
\hline 139 & 100 & - & - & 70 & $\mathbf{T}$ & - & na & na & na & Outcrop-chip-10 ft. \\
\hline 140 & 100 & - & - & 100 & - & $\mathrm{T}$ & na & na & na & Outcrop-dike-chip-g ft. \\
\hline 141 & 400 & - & - & 100 & - & - & na & na & na & Adit-dump $(1,000$ tons $)-g r a b$ \\
\hline 142 & 400 & - & - & 100 & - & - & na & na & na & Ad1t-dump (1,000 tons)-grab-specimer \\
\hline 143 & - & - & - & 100 & - & .1 & na & na & na & Adit-dump ( 600 tons) $-\mathrm{grab}$ \\
\hline 144 & 100 & - & - & 70 & $\mathrm{~T}$ & .1 & na & na & na & Pit-dike-chip-4 ft. \\
\hline 145 & 100 & - & - & 100 & - & - & na & na & na & Outcrop-dike-chip-7 ft. \\
\hline 146 & 400 & - & - & 100 & - & - & na & na & na & Outcrop-d1ke-ch1p-0.5 ft. \\
\hline 147 & 400 & - & - & 100 & - & .1 & na & na & na & Outcrop-dike-ch1p-1.25 ft. \\
\hline 148 & 100 & - & - & 70 & $\mathbf{T}$ & .1 & na & na & na & Ad1t-dump ( 25 tons)-grab \\
\hline $149+$ & 90 & - & - & 1,000 & - & $\mathrm{T}$ & na & na & na & Stream-panned concentrate \\
\hline 150 & 400 & $<1,000$ & - & 70 & $\mathbf{T}$ & - & na & na & na & Outcrop-ve1n-ch1p-0.5 ft. \\
\hline 151 & 100 & - & - & 200 & $\mathrm{~T}$ & - & na & na & na & Do. \\
\hline 152 & - & - & - & 100 & $\mathbf{T}$ & .1 & na & na & na & Shaft-dump (25 tons)-grab \\
\hline 153 & 100 & - & - & 100 & - & - & na & na & na & Ad1t-face-veinlet-chip-0.5 in. \\
\hline 154 & 100 & - & - & 100 & - & $\mathrm{T}$ & na & na & na & Ad1t-face-ve1n-ch1p-1.25 ft. \\
\hline 155 & 100 & - & - & 200 & $\mathrm{~T}$ & - & na & na & na & Outcrop-gouge-chip-0.5 ft. \\
\hline $156 t$ & 200 & - & - & 300 & $\mathbf{T}$ & $\mathrm{r}$ & na & na & na & Stream-sediment \\
\hline 157 & - & - & - & 70 & - & .1 & na & na & na & Ad1t-dump ( 60 tons)-grab \\
\hline 158 & - & - & - & - & - & - & na & na & na & Adit-dump (50 tons)-grab \\
\hline 159 & - & - & - & 70 & - & - & na & na & na & Adft-dump ( 500 tons) $-8 \mathrm{rab}$ \\
\hline $160 t$ & 2,000 & - & - & - & - & .4 & na & 0.03 & na & Pit-ve1n-ch1p-3 ft. \\
\hline 161 & 400 & - & 1,000 & 70 & - & 4.4 & na & na & 0.12 & P1t-dump (15 tons)-grab \\
\hline 162 & 6,000 & - & 2,000 & - & - & .5 & na & .32 & .16 & Adit-stockpile ( 100 lb.)-grab \\
\hline 163 & 500 & - & - & 70 & - & - & na & na & na & Ad1t-dump ( 80 tons)-grab \\
\hline 164 & - & - & - & 70 & - & - & na & na & na & Shaft-dump ( 30 tons) -grab \\
\hline $165 t$ & 3,000 & - & - & 200 & - & - & .01 & .07 & na & Adit-ve1n-ch1p-5 ft. \\
\hline $166 \dot{\top}$ & - & - & - & 300 & - & - & na & na & na & Ad1t-s tope-muck-grab \\
\hline 167 & 6,000 & - & - & $<70$ & - & .3 & .02 & .31 & na & Adit-dump ( 600 tons)-grab \\
\hline $168+$ & 3,000 & - & - & - & - & - & .04 & .06 & na & Adit-face-vein-chip-1 ft. \\
\hline 169 & - & - & - & 300 & - & - & na & na & na & Adit-face-chip- $4 \mathrm{ft}$ \\
\hline 170 & - & - & $\rightarrow$ & - & - & - & na & na & na & Adit-face-ch $1 p-3 \mathrm{ft}$. \\
\hline 171 & - & - & - & - & - & - & na & na & na & Ad1t-face-muck-grab \\
\hline 172 & - & - & - & 200 & - & - & na & na & na & P1t-ve1n-chip-1 ft. \\
\hline 173 & $<100$ & - & - & 70 & $T$ & - & na & na & na & Adit-face-chip-4 ft. \\
\hline 174 & $<100$ & - & - & $<70$ & $\mathrm{~T}$ & - & na & na & na & Pit-vein-chip-2 ft. \\
\hline 175 & 500 & - & - & $<70$ & - & - & na & na & na & Adi t-dump (100 tons)-grab \\
\hline 176 & 400 & $<1,000$ & - & $<70$ & - & $\mathbf{T}$ & na & na & na & Adit-portal-vein-ch1p-2 ft. \\
\hline 177 & 400 & $<1,000$ & - & $<70$ & $\mathrm{~T}$ & .1 & na & na & na & Ad1t-portal-vein-ch1p-2.5 ft. \\
\hline 178 & 200 & - & - & 70 & $T$ & .2 & na & na & na & Outcrop-dike-chtp-2.5 ft. \\
\hline 179 & 400 & - & - & $<70$ & $\mathrm{~T}$ & .1 & na & na & na & Outcrop-chip-35 ft. \\
\hline 180 & 200 & - & - & $<70$ & $\mathbf{T}$ & .2 & na & na & na & Outcrop-chip-50 ft. \\
\hline
\end{tabular}


TABLE 11.-Analyses of samples from study areas

\begin{tabular}{|c|c|c|c|c|c|c|c|c|c|c|c|c|c|}
\hline \multirow[b]{3}{*}{ Sample } & \multirow[b]{3}{*}{$\begin{array}{l}\text { Location } \\
\text { T. R. S. }\end{array}$} & \multicolumn{12}{|c|}{ Semiquantitative spectrographic analyses } \\
\hline & & \multicolumn{6}{|c|}{ percent } & \multicolumn{6}{|c|}{ ppm } \\
\hline & & $\begin{array}{c}\mathrm{A1} \\
(.003)\end{array}$ & $\begin{array}{c}\mathrm{Ca} \\
(.02) \\
(.02\end{array}$ & $\begin{array}{c}\mathrm{Fe} \\
(.004)\end{array}$ & $\begin{array}{c}\mathrm{Mg} \\
(.004) \\
\end{array}$ & $\begin{array}{c}\mathrm{Mn} \\
(.003) \\
\end{array}$ & $\begin{array}{c}\mathrm{ri} \\
(.001) \\
\end{array}$ & $\begin{array}{c}\mathrm{B} \\
(100) \\
\end{array}$ & $\begin{array}{c}\mathrm{Ba} \\
(1,000)\end{array}$ & $\begin{array}{l}\mathrm{Cr} \\
(30) \\
\end{array}$ & $\begin{array}{c}\mathrm{Cu} \\
(20) \\
\end{array}$ & $\begin{array}{c}\text { Mo } \\
(20)\end{array}$ & $\begin{array}{r}\mathrm{NI} \\
(20) \\
\end{array}$ \\
\hline 181 & $44-7-24 *$ & M & 0.2 & 4.0 & 0.2 & 0.02 & 0.1 & - & 1,000 & 30 & 40 & - & - \\
\hline 182 & $44-7-23 *$ & $>5.0$ & .5 & 3 & .8 & .8 & .1 & - & - & 200 & 200 & - & $<20$ \\
\hline 183 & $44-7-23 *$ & $\mathrm{M}$ & .2 & 6 & .4 & .05 & .2 & - & - & 60 & 80 & - & - \\
\hline $184 \dagger$ & $44-7-16 *$ & 2 & .04 & 1 & .1 & .02 & .05 & $<100$ & $<1,000$ & 60 & 80 & - & - \\
\hline 185 & $44-7-16 *$ & M & .3 & 3 & .4 & .05 & .2 & - & $<1,000$ & 60 & 80 & - & - \\
\hline 186 & $44-7-21 *$ & 4 & .1 & 2 & .3 & .03 & .1 & - & - & 100 & 80 & - & - \\
\hline 187 & $44-7-21^{*}$ & 4 & .1 & 2 & .3 & .03 & .1 & - & - & 100 & 80 & - & - \\
\hline 188 & $44-7-21 *$ & 3 & .1 & 4 & .4 & .05 & .1 & .- & - & - & 40 & - & - \\
\hline $189+$ & $44-7-17 *$ & .5 & .03 & 4 & .006 & .02 & .2 & - & - & 50 & 10,000 & 20 & - \\
\hline 190 & $44-7-17^{\star}$ & 2 & .02 & 3 & .05 & .2 & .02 & - & - & 100 & 300 & 30 & - \\
\hline $191+$ & $44-7-17 *$ & 1 & .03 & 3 & .1 & .2 & .1 & 100 & - & 100 & 80 & 70 & - \\
\hline 192 & $44-7-17 *$ & 4 & M & 6 & .8 & .05 & .1 & 100 & - & 100 & 40 & - & - \\
\hline $193+$ & $44-7-17^{\star}$ & .2 & - & 2 & .05 & .1 & .01 & - & - & 50 & 300 & 70 & - \\
\hline 194 & $44-7-17^{*}$ & .7 & - & $i$ & .05 & .1 & .02 & - & - & 50 & 80 & 70 & - \\
\hline $195+$ & $44-7-17 *$ & M & .1 & 3 & .5 & .4 & .2 & 300 & - & 100 & 40 & - & - \\
\hline $196 t$ & $44-7-17^{\star}$ & .7 & .03 & 1 & .01 & .03 & .02 & - & - & 300 & 600 & $<20$ & 20 \\
\hline $197 \%$ & $44-7-18 *$ & .2 & .1 & 2 & .5 & .2 & .2 & 300 & - & 100 & 600 & - & - \\
\hline 198 & $44-7-18 *$ & 1 & .03 & 2 & .01 & .05 & .05 & - & - & 300 & 60 & 20 & 20 \\
\hline 199 & $44-7-18 *$ & 3 & .5 & 3 & .2 & .2 & .05 & - & 40,000 & 300 & 300 & $<20$ & 20 \\
\hline $200+$ & $44-7-18 *$ & 1 & - & 4 & .01 & .03 & .05 & - & 30,000 & 500 & 300 & 70 & 20 \\
\hline 201 & $44-7-18 *$ & .2 & .06 & 3 & .05 & .05 & .05 & 100 & - & 100 & 40 & - & - \\
\hline 202 & $44-7-7^{\star}$ & $M^{2}$ & .03 & 4 & .4 & .01 & .2 & 100 & - & 50 & 200 & 50 & - \\
\hline 203 & $44-7-7 *$ & 5 & .06 & 3 & .2 & .05 & .1 & - & 40,000 & 60 & 200 & 30 & - \\
\hline 204 & $44-7-18 *$ & 3 & 1 & M & .8 & .1 & .1 & - & - & 60 & 200 & 20 & - \\
\hline 205 & $44-7-18 *$ & 2 & .5 & 2 & .3 & .2 & .06 & - & - & 300 & 100 & $<20$ & 20 \\
\hline 206 & $44-7-18 *$ & M & .06 & 3 & .2 & .03 & .2 & 200 & - & 50 & 100 & 30 & - \\
\hline 207 & $44-7-18^{*}$ & .2 & - & 1 & $<.004$ & .003 & .006 & - & - & 300 & 200 & 30 & 20 \\
\hline 208 & $44-7-18 *$ & 1 & .4 & .4 & .3 & .2 & .02 & - & - & 200 & 1,000 & $<20$ & 20 \\
\hline $209 \div$ & $44-8-12^{\star}$ & 2 & .06 & 3 & .1 & .8 & .05 & - & 7,000 & 50 & 3,000 & 50 & - \\
\hline $210+$ & $44-8-12 *$ & 3 & .3 & 2 & .3 & .4 & .1 & - & M & 300 & 300 & 30 & 20 \\
\hline $211 \uparrow$ & $44-8-12 *$ & 2 & M & 2 & .1 & .2 & .1 & 100 & 4,000 & 30 & 40 & $<20$ & - \\
\hline $212 \uparrow$ & $44-8-12 \star$ & .2 & .06 & 1 & .02 & .4 & .006 & 100 & 40,000 & - & 1,000 & - & - \\
\hline $213 \dagger$ & $44-8-12 \star$ & .3 & .06 & 1 & .05 & .2 & .006 & - & M & 60 & 1,000 & 30 & - \\
\hline 214 & $44-8-12 *$ & M & .3 & 4 & .8 & 5 & .2 & 300 & 2,000 & 60 & 400 & 30 & - \\
\hline 215 & $44-8-12 \star$ & 2 & .5 & 3 & .4 & 3 & .1 & - & 1,000 & 60 & 300 & 30 & - \\
\hline $216+$ & $44-8-12 \star$ & 2 & .3 & 1 & .3 & .2 & .05 & 100 & 6,000 & 60 & 600 & - & - \\
\hline $217+$ & $44-8-12 *$ & .7 & .03 & 1 & .1 & .05 & .01 & - & 4,000 & 60 & 600 & 70 & - \\
\hline 218 & $44-8-12 \star$ & 4 & $M$ & 2 & 1.5 & .4 & .2 & 200 & 2,000 & 60 & 80 & - & - \\
\hline 219 & $44-8-12^{*}$ & 1 & .5 & 1 & .4 & 1 & .1 & 200 & 2,000 & 60 & 200 & - & - \\
\hline $220+$ & $44-7-7 \star$ & .7 & - & 4 & .1 & .05 & .01 & - & 1,000 & 60 & 3,000 & 50 & - \\
\hline $221+$ & $44-7-7 *$ & 2 & - & 2 & .2 & .05 & .01 & - & - & 60 & 1,000 & 70 & - \\
\hline 222 & $44-7-7 *$ & 5 & 2 & 2 & 3 & .2 & .1 & 200 & 2,000 & 60 & 100 & - & - \\
\hline 223 & $44-7-7 \star$ & .7 & 1 & 1 & .1 & .1 & .01 & - & - & 60 & 40 & 30 & - \\
\hline $224 t$ & $44-7-7 *$ & .3 & .2 & 4 & .1 & 5 & .02 & - & M & 60 & 200 & 30 & - \\
\hline 225 & $44-7-7^{*}$ & $s$ & 4 & 1 & 1.5 & .05 & .1 & 1,000 & - & 30 & 20 & - & - \\
\hline $226 t$ & $44-7-7 \star$ & 4 & .2 & 1 & .4 & .05 & .05 & 1,000 & - & 30 & 20 & 30 & - \\
\hline $227+$ & $44-7-7 *$ & .7 & .1 & 1 & .1 & .1 & .003 & - & 70,000 & 30 & 80 & 70 & - \\
\hline $228 \div$ & $44-7-7 *$ & .3 & .3 & .4 & .05 & .1 & .003 & - & M & 30 & 40 & 500 & - \\
\hline $229+$ & $44-7-7 *$ & 2 & .5 & 3 & .2 & .1 & .02 & - & M & 60 & 160 & 30 & - \\
\hline 230 & $44-7-7 \star$ & .1 & M & .4 & .1 & .4 & - & - & 30,000 & 30 & 80 & 30 & - \\
\hline 231 & $44-7-6^{\star}$ & .7 & .1 & & .2 & .05 & .05 & - & - & 30 & 20 & - & - \\
\hline 232 & $44-7-6 *$ & 2 & .5 & 2 & .2 & .05 & .05 & - & - & 300 & 80 & 30 & - \\
\hline 233 & $44-7-6 *$ & .02 & M & .2 & .2 & .05 & - & - & - & - & 20 & - & - \\
\hline 234 & $44-7-6 *$ & 4 & 4 & 1 & .8 & .05 & .05 & 1,000 & - & 60 & 40 & - & - \\
\hline 235 & $44-7-6 *$ & 3 & .2 & 1 & .8 & .05 & .05 & 1,000 & - & 30 & 40 & - & - \\
\hline 236 & $44-7-6 *$ & 5 & 4 & 1 & 1.5 & .05 & .1 & 1,000 & - & 30 & 20 & - & - \\
\hline 237 & $44-7-6 *$ & 2 & M & .4 & .4 & .05 & .05 & - & - & 60 & 40 & - & - \\
\hline 238 & $44-7-6 *$ & 3 & $M$ & .4 & .8 & .05 & .1 & - & - & 60 & 40 & 20 & - \\
\hline 239 & $44-8-12 *$ & 2 & 1 & .4 & .2 & .1 & .02 & - & - & - & 300 & - & - \\
\hline 240 & $44-8-1 \star$ & 2 & M & .6 & .4 & .2 & .02 & - & - & - & 300 & - & - \\
\hline
\end{tabular}


CONTIGUOUS AREAS, UNCOMPAHGRE PRIMITIVE AREA, COLO. E115

contiguous to the Uncompahgre Primitive Area-Continued

\begin{tabular}{|c|c|c|c|c|c|c|c|c|c|c|}
\hline \multirow[b]{3}{*}{ Sample } & \multicolumn{4}{|c|}{$\begin{array}{c}\text { Semiquantitative spectrographic } \\
\text { analyses--Continued }\end{array}$} & \multirow{2}{*}{\multicolumn{2}{|c|}{$\frac{\text { Fire assay }}{\text { oz/ton }}$}} & \multirow{2}{*}{\multicolumn{3}{|c|}{$\begin{array}{c}\begin{array}{c}\text { Atomic absorption } \\
\text { analyses }\end{array} \\
\text { percent }\end{array}$}} & \multirow{3}{*}{ Sample data } \\
\hline & \multicolumn{4}{|c|}{ ppm } & & & & & & \\
\hline & $\begin{array}{c}\mathrm{Pb} \\
(100)\end{array}$ & $\begin{array}{c}\mathbf{S r} \\
(1,000)\end{array}$ & $\begin{array}{c}2 n \\
(1,000) \\
\end{array}$ & $\begin{array}{c}\mathrm{Zr} \\
(70)\end{array}$ & $\mathrm{Au}$ & $\mathrm{Ag}$ & $\mathrm{Cu}$ & $\mathrm{Pb}$ & $\mathrm{Zn}$ & \\
\hline 181 & 400 & - & - & $<70$ & - & $\mathrm{T}$ & na & na & na & Outcrop-chip-10 ft. \\
\hline 182 & 200 & - & - & 70 & $\mathrm{~T}$ & 0.1 & na & na & na & Outcrop-cinip-6 ft. \\
\hline 183 & 700 & - & - & $<70$ & $\mathrm{~T}$ & .2 & na & na & na & Outcrop-chip-15 ft. \\
\hline $184 t$ & 100 & 1,000 & - & $<70$ & $\mathbf{T}$ & $\mathrm{T}$ & na. & na & na & Adit-dump (150 tons)-grab \\
\hline 185 & 100 & 1,000 & - & $<70$ & $\mathrm{~T}$ & $\mathrm{~T}$ & na & na & na & Adit-portal-ve1n-ch1p- $4 \mathrm{ft}$. \\
\hline 186 & - & - & - & 70 & $\mathrm{~T}$ & $\mathrm{~T}$ & na & na & na & Adit-face-ch1p-3 ft. \\
\hline 187 & - & - & - & 70 & - & - & na & na & na & Do. \\
\hline 188 & 700 & - & - & 100 & $\mathrm{~T}$ & .1 & na & no & na & Ad1t-portal-veln-chip-1.5 ft. \\
\hline $189+$ & 700 & - & 1,000 & 100 & 0.09 & 12.7 & 1.68 & & 4.7 & Shaft-stockp1le(150 ib.)-grab \\
\hline 190 & M & - & M & 100 & .01 & 6.9 & na & 1.36 & 2.77 & Shaft-dump (600 tons)-grab \\
\hline $191 \dagger$ & 20,000 & - & 5,000 & 100 & $\mathrm{~T}$ & 15.3 & na & 1.08 & .57 & Shaf t-dump ( 250 tons) $-8 \mathrm{rab}$ \\
\hline 192 & 100 & - & - & 100 & $\mathrm{~T}$ & $\mathrm{~T}$ & na & na & na & Shaft-dump (150 tons)-grab \\
\hline $193 \div$ & 10,000 & - & 1,000 & 100 & $\mathrm{~T}$ & 9.5 & na & .58 & .18 & Shaft-dump ( 500 tons)-grab \\
\hline 194 & 10,000 & - & - & 100 & .01 & 4.5 & na & .47 & na & Adit-dump ( 800 tons $)-\mathrm{grab}$ \\
\hline $195+$ & 700 & - & 2,000 & 100 & $\mathrm{~T}$ & .2 & na & na & .08 & Adit-dump ( 150 tons)-grab \\
\hline $196 t$ & M & - & 3,000 & 70 & $\mathrm{~T}$ & 39.8 & .07 & 6.97 & .05 & Adit-dump ( 75 tons)-grab \\
\hline $197+$ & 700 & - & 1,000 & 100 & - & .2 & .02 & .02 & .04 & Ad $1-\mathrm{face}-\operatorname{ch} 1 \mathrm{p}-4 \mathrm{ft}$. \\
\hline 198 & 700 & - & - & 70 & $\mathrm{~T}$ & .3 & na & na & na & Ad1t-dump ( 400 tons)-grab \\
\hline 199 & 6,000 & - & 20,000 & $<70$ & $\mathrm{~T}$ & 6.1 & na & .45 & 1.07 & Ad1t-dump (600 tons)-grab \\
\hline $200+$ & 10,000 & - & 5,000 & $<70$ & .01 & 6.3 & na & 1.08 & .23 & Ad1t-dump $(1,500$ tons $)-g r a b$ \\
\hline 201 & 400 & - & 1,000 & 100 & $\mathbf{T}$ & .3 & na & na & .03 & Adit-dump (600 tons)-grab \\
\hline 202 & 200 & - & - & 100 & $\mathbf{T}$ & .1 & na & na & na & Ad1t-wall-veln-chip- $6 \mathrm{ft}$. \\
\hline 203 & 10,000 & - & 2,000 & $<70$ & $\mathrm{~T}$ & .5 & na & .12 & .05 & Ad1t-face-ch $1 p-3 \mathrm{ft}$ \\
\hline 204 & 700 & - & - & $<70$ & $\mathrm{~T}$ & .1 & na & na & na & P1t-dump ( 50 tons)-grab \\
\hline 205 & 400 & - & - & $<70$ & $\mathrm{~T}$ & 4.9 & na & na & na & Adit-face-chip-6 ft. \\
\hline 206 & 6,000 & - & 3,000 & 100 & $\mathbf{T}$ & .5 & na & .21 & .29 & P1t-face-ve1n-ch1p-1 ft. \\
\hline 207 & 10,000 & - & 6,000 & - & $\mathrm{T}$ & 3.8 & na & .91 & .52 & P1t-dump (200 tons)-grab \\
\hline 208 & 300 & - & - & - & $\mathbf{T}$ & 1.2 & .19 & na & na & Adit-stockpile (500 lb.) -grab \\
\hline $209+$ & M & 1,000 & M & 100 & $\mathrm{~T}$ & 29.5 & .15 & 8.28 & 6.36 & Adit-stockpile(1 ton)-grab \\
\hline $210 \dagger$ & 10,000 & - & 3,000 & $<70$ & $\mathbf{T}$ & 22.4 & na & .45 & .13 & Ad1t-s tockp1le $(3001 \mathrm{~b})-.\mathrm{grab}$ \\
\hline $211+$ & 30,000 & $<1,000$ & 3,000 & $<70$ & .02 & 20.2 & .08 & 1.06 & .29 & Adit-stockpile(1 ton)-grab \\
\hline $212+$ & 10,000 & $<1,000$ & 40,000 & $<70$ & .02 & 6.2 & .05 & 1.11 & 2.22 & Adit-s tockpile ( 1.5 tons $)-g$ rab \\
\hline 213 & 10,000 & 2,000 & 10,000 & - & $\mathbf{T}$ & 14.7 & .12 & .56 & .75 & Ad1t-stockp1le $(600 \mathrm{lb})-.\mathrm{grab}$ \\
\hline 214 & 8,000 & - & 4,000 & $<70$ & $\mathrm{~T}$ & 1.6 & na & .44 & .22 & Adit-face-vein-chip-2.5 ft. \\
\hline 215 & 400 & - & - & $<70$ & - & .3 & na & na & na & Adit-face-vein-chip- $1.5 \mathrm{ft}$. \\
\hline $216+$ & 8,000 & - & 2,000 & $<70$ & $\mathrm{~T}$ & 2.9 & 0.7 & .15 & .10 & Ad1t-muck pile \\
\hline $217 \dagger$ & 20,000 & - & - & - & .02 & 5.6 & .13 & .79 & na & Adit-back-chip-2 ft. \\
\hline 218 & 700 & - & - & 100 & $\mathbf{T}$ & .4 & na & na & na & Ad1t-wa11-ve1n-ch1p-0.75 ft. \\
\hline 219 & 1,000 & - & - & $<70$ & - & .4 & na & .03 & na & Ad1t-wa11-ve1n-ch1p-1 ft. \\
\hline $220+$ & 50,000 & - & 5,000 & - & .27 & 22.7 & .30 & 1.32 & .44 & Adit-face-chip-2 ft. \\
\hline $221+$ & 50,000 & - & 3,000 & - & .12 & 10.8 & .16 & 1.23 & .19 & Adit-face-vein-chip-2 ft. \\
\hline 222 & 500 & - & - & $<70$ & $\mathrm{~T}$ & .3 & na & & na & Adit-caved stope-grab \\
\hline 223 & 200 & - & - & - & - & .3 & na & na & na & Adit-wall-vein-chip-4 ft. \\
\hline $224 t$ & 10,000 & 5,000 & - & - & .01 & 1.1 & na & 1.34 & na & Ad1t-wall-veln-chip-7 ft. \\
\hline 225 & 100 & - & - & 70 & - & - & na & na & na & Adit-face-chip-4 ft. \\
\hline $226+$ & 3,000 & - & 1,000 & 70 & $\mathrm{~T}$ & 2.3 & na & .16 & .15 & Ad1t-face-chip- $4 \mathrm{ft}$ \\
\hline $227 t$ & 30,000 & 8,000 & 40,000 & - & $\mathrm{T}$ & 1.4 & na & 1.11 & 2.67 & Ad1t-s tockplle (2 tons)-grab \\
\hline $228+$ & 10,000 & 4,000 & 3,000 & - & - & .6 & na & .51 & .12 & Do. \\
\hline $229 \dagger$ & 50,000 & 4,000 & 5,000 & 70 & $\mathrm{~T}$ & 3.3 & na & 2.00 & .30 & Do. \\
\hline 230 & 3,000 & 1,000 & 2,000 & - & - & .7 & na & .27 & .05 & Adit-winze-ve1n-ch1p-2.5 ft. \\
\hline 231 & - & - & - & 70 & - & - & na & & & Ad1t-face-chip-5 ft. \\
\hline 232 & 200 & - & - & - & $T$ & - & na & na & na & Ad1t-wall-vein-chip-1.5 ft. \\
\hline 233 & - & - & - & - & - & - & na & na & na & Adit-face-chip-2 ft. \\
\hline 234 & 100 & - & - & $<70$ & - & - & na & na & na & Adit-face-chip- $4 \mathrm{ft}$. \\
\hline 235 & 100 & - & - & $<70$ & - & - & na & na & na & Do. \\
\hline 236 & 100 & - & - & 70 & - & .1 & na & & na & Adit-s tope-grab \\
\hline 237 & 800 & - & - & - & - & .1 & na & na & na & Adit-face-chip- $4 \mathrm{ft}$. \\
\hline 238 & 100 & - & - & $<70$ & - & $T^{*}$ & $\begin{array}{l}\text { na } \\
\text { na }\end{array}$ & & & Adit-face-chip-4.5 ft. \\
\hline 239 & 4,000 & - & 4,000 & 100 & - & .2 & na & $\stackrel{\text { na }}{.15}$ & $\begin{array}{l}\text { na } \\
.20\end{array}$ & P1t-dump (10 tons)-grab \\
\hline 240 & 5,000 & - & 5,000 & 70 & $\mathrm{~T}$ & .1 & $\begin{array}{l}\text { na } \\
\text { na }\end{array}$ & .40 & .36 & Adit-face-vein-chip-3 ft. \\
\hline
\end{tabular}


TABLE 11.-Analyses of samples from study areas

\begin{tabular}{|c|c|c|c|c|c|c|c|c|c|c|c|c|c|c|}
\hline \multirow[b]{3}{*}{ Sample } & \multirow{3}{*}{\multicolumn{2}{|c|}{$\begin{array}{l}\text { Location } \\
\text { T. R. S. }\end{array}$}} & \multicolumn{12}{|c|}{ Semiquantitative spectrographic analyses } \\
\hline & & & \multicolumn{6}{|c|}{ percent } & \multicolumn{6}{|c|}{$\mathrm{ppm}$} \\
\hline & & & $\begin{array}{c}\mathrm{A} 1 \\
(.003) \\
\end{array}$ & $\begin{array}{c}\mathrm{Ca} \\
(.02) \\
\end{array}$ & $\begin{array}{c}\mathrm{Fe} \\
(.004) \\
.04\end{array}$ & $\begin{array}{c}\mathrm{Mg} \\
(.004) \\
\end{array}$ & $\begin{array}{c}\mathrm{Mn} \\
(.003) \\
\end{array}$ & $\begin{array}{c}\mathrm{T1} \\
(.001) \\
\end{array}$ & $\begin{array}{c} \\
(100)\end{array}$ & $\begin{array}{c}\mathrm{Ba} \\
(1,000)\end{array}$ & $\begin{array}{c}\mathrm{Cr} \\
(30) \\
\end{array}$ & $\begin{array}{c}\mathrm{Cu} \\
(20) \\
\end{array}$ & $\begin{array}{l}\text { Mo } \\
(20)\end{array}$ & $\begin{array}{c}\mathrm{NI} \\
(20) \\
\end{array}$ \\
\hline 241 & 44- & $8-1 *$ & 4.0 & 1.0 & 0.6 & 0.4 & 0.05 & 0.05 & 200 & - & - & 40 & - & - \\
\hline 242 & 44- & 8- I* & 1 & .4 & .6 & .4 & .05 & .05 & 100 & - & - & 40 & - & - \\
\hline 243 & 44- & $8-1^{*}$ & 2 & $\mathrm{M}$ & .4 & .2 & .05 & .02 & 200 & - & - & 600 & - & - \\
\hline 244 & 44- & $8-1^{*}$ & 3 & M & 2 & .8 & .05 & .1 & 100 & - & 60 & 40 & - & - \\
\hline $245+$ & 44- & $8-1 *$ & 2 & 2 & 2 & .4 & .05 & .1 & 200 & - & 60 & 10,000 & 30 & - \\
\hline $246 \dagger$ & 44- & $8-1^{*}$ & 3 & .06 & 3 & .8 & .2 & .1 & - & - & 300 & 60 & $<20$ & 1,000 \\
\hline 247 & 44- & $7-6 *$ & 2 & .02 & 2 & .05 & .01 & .05 & - & - & 30 & 40 & 20 & \\
\hline 248 & 44- & $7-6 *$ & 4 & .06 & 2 & .1 & .1 & .1 & - & - & 200 & 60 & $<20^{\circ}$ & - \\
\hline 249 & $45-$ & $7-31 *$ & $>5$ & 1 & 3 & .8 & .1 & .1 & - & - & 100 & 40 & $<20$ & - \\
\hline 250 & $45-$ & $7-31 *$ & 2 & .06 & 1 & .1 & .1 & .06 & - & - & 100 & 60 & $<20$ & 20 \\
\hline 251 & 45- & $8-36 *$ & 4 & .06 & 2 & .1 & .03 & .07 & - & - & 70 & 30 & - & $<20$ \\
\hline 252 & $45-$ & $8-36$ * & 4 & .1 & 2 & .1 & .05 & .07 & - & - & 70 & 60 & - & $<20$ \\
\hline 253 & 44- & $8-2 *$ & 2 & $>4$ & 2 & .8 & .05 & .1 & - & - & 200 & 300 & - & 20 \\
\hline 254 & 44- & $8-2 *$ & 3 & $>4$ & 2 & 2 & .05 & .1 & - & - & 200 & 80 & - & 20 \\
\hline 255 & 44- & $8-10 *$ & .3 & M & - & .4 & .02 & .02 & - & - & - & 20 & - & - \\
\hline 256 & 44- & $8-10 *$ & 3 & M & - & .4 & .02 & .02 & - & - & - & 20 & - & - \\
\hline 257 & 44- & $8-10^{*}$ & 2 & .02 & 2 & .1 & .05 & .05 & - & - & 100 & 60 & - & - \\
\hline 258 & 44- & $8-11 *$ & 5 & M & 2 & .8 & .1 & .2 & 300 & - & 100 & 80 & - & - \\
\hline $259+$ & 44- & $8-11 *$ & 1 & .13 & 3 & .8 & .4 & .1 & 100 & - & - & 400 & - & - \\
\hline $260 \dagger$ & & $8-11^{*}$ & 3 & .13 & 4 & .4 & .05 & .2 & - & - & - & 40,000 & 30 & - \\
\hline $261+$ & 44- & $8-11 *$ & M & .13 & 2 & .2 & .1 & .1 & 100 & 40,000 & - & 30,000 & 30 & - \\
\hline $262 \dagger$ & 44- & $8-11^{\star}$ & 2 & 3 & 2 & .3 & 3 & .05 & - & 70,000 & 30 & 1,500 & 30 & - \\
\hline 263 & 44- & $8-11 *$ & 4 & M & 3 & 3 & .1 & .1 & 100 & 40,000 & 60 & 1,500 & 70 & - \\
\hline 264 & 44- & $8-22^{*}$ & M & .5 & 5 & .8 & .05 & .2 & - & - & 100 & 60 & - & - \\
\hline 265 & $44-$ & $8-22 \star$ & 5 & 4 & 4 & .8 & .1 & .2 & - & - & 100 & 40 & - & - \\
\hline $266+$ & 44- & $8-23 *$ & 3 & .3 & 2 & .6 & .1 & .1 & - & 1,000 & 60 & 80 & 30 & - \\
\hline 267 & 44- & $8-23 *$ & M & .2 & 1 & .6 & .2 & - & 200 & - & 60 & 1,500 & - & - \\
\hline 268 & 44- & $8-23 *$ & M & 1 & 4 & .8 & 2 & .1 & 100 & 1,000 & 60 & 1,500 & - & - \\
\hline $269+$ & $44-$ & $8-23 *$ & 3 & 1 & 1 & .4 & 1.6 & .05 & - & - & 30 & 7,000 & - & - \\
\hline $270+$ & 44- & $8-23 *$ & 2 & 2 & 1 & .6 & $M$ & .02 & - & 3,000 & 30 & 7,000 & - & - \\
\hline 271 & 44- & $8-23 *$ & 5 & 5 & 1 & .8 & .1 & - & 100 & - & 30 & 80 & - & - \\
\hline 272 & 44- & $8-23 *$ & M & 3 & 1 & .8 & .1 & - & 100 & - & 30 & 80 & - & - \\
\hline 273 & $44-$ & $8-24 *$ & M & 4 & 1 & $1^{\circ}$ & .2 & .1 & 100 & 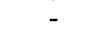 & 100 & 300 & 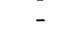 & - \\
\hline $274 t$ & 44- & $8-24 *$ & 5 & 1 & 4 & 1 & 6 & .1 & 100 & 1,000 & 100 & 20,000 & - & - \\
\hline 275 & 44- & $8-23 *$ & 3 & M & 4 & .4 & .1 & .1 & 100 & 20,000 & 50 & 3,000 & - & - \\
\hline $276+$ & $44-$ & $8-24^{*}$ & 3 & .06 & .2 & .4 & .02 & .1 & 100 & - & 100 & 10,000 & 30 & - \\
\hline 277 & & $8-23 *$ & .3 & .1 & 4 & .2 & .04 & .02 & - & - & 100 & 160 & 30 & - \\
\hline 278 & 44- & $8-23 *$ & .1 & M & 2 & .4 & .4 & - & - & 2,000 & - & 20 & - & - \\
\hline $279+$ & 44- & $8-23 *$ & M & - & 3 & .4 & .05 & .2 & 2,000 & 4,000 & 100 & 30 & 70 & - \\
\hline 280 & 44- & $8-23 *$ & 5 & 1 & 2 & .8 & .1 & .05 & 200 & - & 50 & 40 & - & - \\
\hline 281 & 44- & $8-23 *$ & 4 & $M$ & 2 & .8 & .4 & .05 & - & 2,000 & - & 40 & - & - \\
\hline 282 & 44- & $8-23 *$ & 3 & M & 1 & .4 & .2 & .05 & - & - & 50 & 40 & 30 & - \\
\hline 283 & 44- & $8-23 *$ & .7 & 1 & 2 & .2 & .2 & .02 & - & - & 100 & 160 & - & - \\
\hline 284 & 44- & $8-23 *$ & M & 1 & 2 & 1.5 & .1 & .2 & 1,000 & 1,000 & 60 & 40 & - & - \\
\hline 285 & 44- & $8-23 *$ & 3 & .03 & 3 & .4 & .02 & .02 & - & - & - & 40 & - & - \\
\hline 286 & $44-$ & $8-23^{\star}$ & M & .1 & 3 & .4 & .02 & .2 & 1,000 & - & - & 40 & 30 & - \\
\hline 287 & & $8-2$ & .3 & 1 & 2 & .05 & .05 & .01 & - & - & - & 40 & - & - \\
\hline $288+$ & & $8-23 *$ & .3 & - & 2 & .02 & .02 & .01 & - & 70,000 & - & 160 & 70 & - \\
\hline 289 & $44-$ & $8-23 *$ & 2 & .1 & 3 & .1 & .02 & .02 & - & 2,000 & - & 80 & 70 & - \\
\hline $290+$ & 44- & $8-23 *$ & 2 & .03 & 2 & .05 & .02 & .02 & - & M & - & 600 & 70 & - \\
\hline $291 t$ & $44-$ & $8-2$ & 1 & .02 & 2 & .02 & .05 & .02 & - & $M$ & - & 80 & 30 & - \\
\hline $292 \div$ & 44- & $8-23 *$ & 3 & .02 & 1 & .02 & .1 & .02 & - & 2,000 & - & 160 & 30 & - \\
\hline 293 & 44- & $8-23 *$ & 2 & .5 & 1 & .1 & .1 & .02 & - & 2. & - & 60 & 30 & - \\
\hline 294 & 44- & $8-23 *$ & 2 & .03 & 2 & .1 & .05 & .02 & - & - & - & 60 & 70 & - \\
\hline 295 & 44- & $8-26$ * & 3 & - & 7 & .2 & .05 & .1 & - & - & 100 & 200 & 30 & - \\
\hline 296 & 44- & $8-26$ * & M & .2 & 7 & 1.5 & .1 & .2 & 100 & 1,000 & 50 & 60 & - & - \\
\hline 297 & & $8-27$ & 5 & .06 & 5 & .8 & .2 & .2 & 200 & - & 100 & 40 & 100 & - \\
\hline 298 & 44- & $8-27 *$ & 3 & M & 4 & .8 & .05 & .2 & - & - & 100 & 40 & - & - \\
\hline 299 & 44- & $8-28 *$ & M & .02 & 2 & .1 & .05 & .05 & - & - & 100 & 60 & - & - \\
\hline 300 & & $8-28 *$ & 5 & M & 6 & 3 & .2 & .2 & - & - & 100 & 100 & - & - \\
\hline
\end{tabular}


CONTIGUOUS AREAS, UNCOMPAHGRE PRIMITIVE AREA, COLO. E117

contiguous to the Uncompahgre Primitive Area-Continued

\begin{tabular}{|c|c|c|c|c|c|c|c|c|c|c|}
\hline \multirow[b]{3}{*}{ Sample } & \multicolumn{4}{|c|}{$\begin{array}{l}\text { Semiquantitative spectrographic } \\
\text { analyses--Cont inued }\end{array}$} & \multirow{2}{*}{\multicolumn{2}{|c|}{$\frac{\text { Fire assay }}{\text { oz/ton }}$}} & \multirow{2}{*}{\multicolumn{3}{|c|}{$\begin{array}{c}\begin{array}{c}\text { Atomic absorption } \\
\text { analyses }\end{array} \\
\text { percent }\end{array}$}} & \multirow{3}{*}{ Sample data } \\
\hline & \multicolumn{4}{|c|}{$\mathrm{ppm}$} & & & & & & \\
\hline & $\begin{array}{c}\mathrm{Pb} \\
(100)\end{array}$ & $\begin{array}{c}\mathrm{Sr} \\
(1,000)\end{array}$ & $\begin{array}{c}2 \mathrm{n} \\
(1,000) \\
\end{array}$ & $\begin{array}{c}\mathrm{Zr} \\
(70)\end{array}$ & $\mathrm{Au}$ & $\mathrm{Ag}$ & $\mathrm{Cu}$ & $\mathrm{Pb}$ & $2 \mathrm{n}$ & \\
\hline 241 & 100 & - & - & 100 & - & $\mathrm{T}$ & na & na & na & Adit-face-chip-3.75 ft. \\
\hline 242 & 200 & $<1,000$ & - & 100 & - & - & na & na & na & Adit-back-vein-ch1p-0.5 ft. \\
\hline 243 & 700 & - & 1,000 & - & 0.03 & 0.2 & 0.25 & na & 0.16 & Adtt-face-chip-6 ft. \\
\hline 244 & 700 & - & - & 100 & $\mathrm{~T}$ & .3 & na & na & na & Adit-dump-( 50 tons $)-8 \mathrm{rab}$ \\
\hline 245 & 1,500 & - & 3,000 & 100 & $\mathrm{~T}$ & .7 & .44 & 0.04 & .17 & Ad1t-wall-vein-chip-1-75 ft. \\
\hline $246 \div$ & 200 & - & 3,000 & $<70$ & $\mathrm{~T}$ & .1 & na & na & .15 & Pit-dump ( 5 tons)-grab \\
\hline 247 & 400 & - & - & $<70$ & $\mathrm{~T}$ & .1 & na & na & na & Pit-dump (15 tons)-grab \\
\hline 248 & 200 & - & - & 70 & $T$ & .2 & na & na & na & Do. \\
\hline 249 & 200 & - & - & 70 & $\mathrm{~T}$ & .2 & na & na & na & Outcrop-chip-3 ft. \\
\hline 250 & 200 & - & - & $<70$ & $\mathrm{~T}$ & .1 & na & na & na & Adit-dump ( 500 tons)-grab \\
\hline 251 & - & - & - & $<70$ & $\mathrm{~T}$ & $\mathbf{T}$ & na & na & na & P1t-dump (25 tons)-grab \\
\hline 252 & - & - & - & $<70$ & $\mathrm{~T}$ & $T$ & na & na & na & Shaft-dump ( 75 tons)-grab \\
\hline 253 & - & - & - & $<70$ & $\mathrm{~T}$ & .2 & na & na & na & Pit-dump (50 tons)-grab \\
\hline 254 & - & - & - & $<70$ & $\mathrm{~T}$ & .2 & na & na & na & Pit-veln-chip-2 ft. \\
\hline 255 & - & $<1,000$ & - & - & - & - & na & na & na & Adit-face-chip-2.75 ft. \\
\hline 256 & - & $<1,000$ & - & - & $\mathrm{T}$ & .1 & na & na & na & Ad1t-face-chip-3.25 ft. \\
\hline 257 & 100 & - & - & 70 & - & .3 & na & na & na & Pit-dump (15 tons)-grab \\
\hline 258 & 1,000 & - & - & $<70$ & - & - & .01 & .05 & na & Adit-dump ( 125 tons)-grab \\
\hline $259+$ & 3,000 & $<1,000$ & 3,000 & 100 & $T$ & .5 & na & .16 & .05 & Adtt-face-chip- $4 \mathrm{ft}$ \\
\hline $260 t$ & 1,500 & $<1,000$ & 3,000 & 70 & - & 45.1 & 3.25 & .09 & .37 & Adit-back-vein-chip-1 ft. \\
\hline $261 \div$ & 10,000 & $<1,000$ & 3,000 & 70 & - & 38.0 & 2.74 & .58 & .28 & Do. \\
\hline $262 i$ & 3,000 & 2,000 & 1,000 & 70 & $\mathrm{~T}$ & 4.8 & .18 & .20 & .07 & Ad1t-dump (1,000 tons $)-g r a b$ \\
\hline 263 & 6,000 & 1,000 & - & 70 & - & 1.6 & .06 & .20 & na & Adit-dump ( 500 tons) - grab \\
\hline 264 & 200 & - & - & 70 & - & .1 & na & na & na & Shaft-dump ( 300 tons $)-g r a b$ \\
\hline 265 & 100 & - & - & 70 & - & - & na & na & na & Trench-dump (20 tons)-grab \\
\hline $266 \dot{r}$ & 700 & - & - & $<70$ & $\mathrm{~T}$ & - & na & na & na & Shaft-dump (100 tons)-grab \\
\hline 267 & 200 & - & - & 70 & $\mathrm{~T}$ & $T$ & .06 & na & na & Pit-vein-chip-0.5 ft. \\
\hline 268 & 700 & $<1,000$ & - & $<70$ & - & .2 & .17 & na & na & Ad1t-dump $(1,700$ tons $)-g r a b$ \\
\hline $269+$ & 400 & $<1,000$ & - & $<70$ & - & 2.4 & .82 & na & na & Do. \\
\hline $270+$ & 700 & $<1,000$ & - & $<70$ & - & 4.3 & .82 & na & na & Do. \\
\hline 271 & - & - & - & 70 & - & .1 & na & na & na & Ad1t-face-chfp- 4 ft. \\
\hline 272 & 100 & - & - & 70 & - & - & na & na & na & Do. \\
\hline 273 & 100 & - & - & 100 & - & - & na & na & na & Pit-face-ch1p-4 ft. \\
\hline $274 t$ & - & 4,000 & - & 70 & - & .4 & 1.44 & na & na & Pit-stockpile(150 lb.)-grab \\
\hline 275 & 400 & - & - & 100 & - & .4 & .22 & na & na & Adit-face-ch1p-4 ft. \\
\hline $276 \div$ & 400 & - & - & 100 & $\mathrm{~T}$ & .08 & .60 & na & na & Pit-face-chtp-6 ft. \\
\hline 277 & 200 & - & - & - & - & - & na & na & na & Adit-face-chip- 4.5 ft. \\
\hline 278 & - & - & - & 100 & - & $\mathbf{T}$ & na & na & na & Adit-face-vein-chip-1 ft. \\
\hline $279 \uparrow$ & 50,000 & - & 5,000 & 100 & $\mathrm{~T}$ & 1.9 & na & 1.11 & .23 & Adit-dump (2,000 tons)-grab \\
\hline 280 & - & - & - & 70 & - & - & $\begin{array}{l}\text { na } \\
\text { na }\end{array}$ & na & na & Adit-face-vein-ch1p-1.25 ft. \\
\hline 281 & - & - & - & - & - & - & na & na & na & Adit-face-muck-grab \\
\hline 282 & 200 & - & - & - & $\mathrm{T}$ & - & na & na & na & Outcrop-ve1n-chip-15 ft. \\
\hline 283 & 200 & $<1,000$ & - & 100 & - & - & na & na & na & Outcrop-vein-chip-10 ft. \\
\hline 284 & 400 & - & - & 100 & - & .1 & na & na & na & Adft-dump ( 75 tons)-grab \\
\hline 285 & 700 & - & - & - & $\mathrm{T}$ & .2 & na & na & na & Pit-dump (200 tons)-grab \\
\hline 286 & 1,500 & - & 1,000 & 100 & - & .1 & na & .04 & .06 & Ad1t-face-vein-ch1p-1 ft. \\
\hline 287 & 800 & - & 2,000 & - & - & .1 & na & .02 & .24 & Adit-face-muck-grab \\
\hline $288 \div$ & 100,000 & 1,000 & 80,000 & - & $T$ & 3.1 & na & 8.57 & 4.86 & Adit-stockpile (500 1b.)-grab \\
\hline 289 & 80,000 & - & 20,000 & - & $\mathrm{T}$ & 1.3 & na & 2.55 & 1.15 & Adit-stockpile (300 lb.)-grab \\
\hline $290+$ & 80,000 & 2,000 & 80,000 & - & - & 20.8 & .04 & 2.00 & 4.29 & Adft-stockpile (800 lb.)-grab \\
\hline $291 \%$ & 30,000 & 2,000 & 20,000 & - & - & 1.6 & na & .99 & 1.08 & Adit-stope-muck-grab \\
\hline $292+$ & 30,000 & - & 80,000 & - & .2 & 9.8 & na & 1.75 & 4.62 & Ad1t-stockp1le $(1,000$ 1b. $)-\mathrm{grab}$ \\
\hline 293 & 3,000 & - & 5,000 & - & - & .3 & na & .17 & .40 & Adit-face-vein-chip-3 ft. \\
\hline 294 & 3,000 & - & 2,000 & - & $T$ & .3 & na & .17 & .14 & Adit-winze-muck-grab \\
\hline 295 & 10,000 & - & 20,000 & 100 & - & .6 & na & .37 & .78 & Outcrop-ve1n-chip-0.5 ft. \\
\hline 296 & 200 & - & - & 100 & - & $\mathrm{T}$ & na & na & & Outcrop-ve1n-chip-1 ft. \\
\hline 297 & $<100$ & - & - & 70 & - & .2 & na & na & na & Ad1t-portal-ve1n-ch1p-2 ft. \\
\hline 298 & 100 & - & - & 70 & $\mathrm{~T}$ & - & na & na & na & Dutcrop-dike-chip-6 ft. \\
\hline 299 & 100 & - & - & 70 & - & - & na & na & na & Outcrop-dike-chip-1 ft. \\
\hline 300 & 100 & - & - & 70 & - & - & na & na & na & Outcrop-d1ke-chip-2 ft. \\
\hline
\end{tabular}


TABLE 11.-Analyses of samples from study areas

\begin{tabular}{|c|c|c|c|c|c|c|c|c|c|c|c|c|c|}
\hline \multirow[b]{3}{*}{ Sample } & \multirow{3}{*}{$\begin{array}{l}\text { Location } \\
\text { T. R. S. }\end{array}$} & \multicolumn{12}{|c|}{ Semiquantitative spectrographic analyses } \\
\hline & & \multicolumn{6}{|c|}{ percent } & \multicolumn{6}{|c|}{ ppm } \\
\hline & & $\begin{array}{c}\mathrm{A1} \\
(.003)\end{array}$ & $\begin{array}{c}\mathrm{Ca} \\
(.02) \\
\end{array}$ & $\begin{array}{c}\mathrm{Fe} \\
(.004) \\
\end{array}$ & $\begin{array}{c}\mathrm{Mg} \\
(.004) \\
\end{array}$ & $\begin{array}{c}\mathrm{Mn} \\
(.003) \\
\end{array}$ & $\begin{array}{c}\mathrm{TI} \\
(.001)\end{array}$ & $\begin{array}{c}\mathrm{B} \\
(100) \\
\end{array}$ & $\begin{array}{c}\mathrm{Ba} \\
(1,000) \\
\end{array}$ & $\begin{array}{c}\mathrm{Cr} \\
(30)\end{array}$ & $\begin{array}{c}\mathrm{Cu} \\
(20)\end{array}$ & $\begin{array}{c}\text { Mo } \\
(20)\end{array}$ & $\begin{array}{c}\mathrm{NI} \\
(20) \\
\end{array}$ \\
\hline 301 & $44-8-32 \star$ & 1.0 & 0.03 & 4.0 & 0.006 & 0.02 & 0.05 & - & - & 200 & 60 & 100 & - \\
\hline 302 & $44-8-32 \star$ & M & M & 4 & .4 & .05 & .2 & - & $<1,000$ & 200 & 40 & - & - \\
\hline 303 & $44-8-31^{*}$ & 5 & .03 & 4 & .1 & .1 & .1 & - & - & 100 & 40 & - & - \\
\hline 304 & $44-8-31^{\star}$ & 3 & 1 & 2 & .4 & .2 & .05 & - & - & 60 & - & - & - \\
\hline 305 & $44-8-31 *$ & $\mathrm{M}$ & M & 6 & .8 & .2 & .8 & - & - & 200 & 40 & - & - \\
\hline 306 & $43-8-6 \star$ & 2 & .3 & 4 & .4 & 3 & .1 & - & - & 100 & 80 & - & - \\
\hline 307 & $43-8-6 *$ & M & .3 & 4 & .8 & .2 & .2 & - & - & 200 & 150 & - & - \\
\hline 308 & $43-8-6 *$ & 3 & 1 & 5 & .8 & 1.6 & .1 & - & - & 200 & 80 & - & - \\
\hline 309 & $43-8-6 *$ & 5 & 2 & 4 & .4 & .8 & .1 & - & - & 100 & 80 & - & - \\
\hline 310 & $43-8-6 *$ & M & .1 & 6 & 1.5 & .2 & .2 & - & 1,000 & 200 & 60 & - & - \\
\hline $311+$ & $43-9-12 \star$ & 5 & .3 & 4 & .4 & .4 & .2 & - & $M$ & 100 & 300 & $<20$ & 20 \\
\hline $312+$ & $43-9-12 *$ & 3 & .2 & $M$ & .2 & 6 & .1 & - & 5,000 & 200 & 1,300 & - & - \\
\hline $313 \leftarrow$ & $43-9-12$ * & 3 & 1 & 7 & .8 & 6 & .1 & - & 1,000 & 200 & 150 & - & - \\
\hline 314 & $43-9-11^{\star}$ & M & .02 & 3 & .4 & .01 & .2 & - & - & 100 & 40 & - & - \\
\hline 315 & $43-9-12 \star$ & u & 1 & $M$ & 1.5 & .8 & .2 & - & 2,000 & 300 & 80 & 40 & - \\
\hline $316 t$ & $43-9-12 *$ & M & .2 & 7 & .4 & .3 & .2 & - & - & 100 & 80 & - & - \\
\hline $317+$ & $43-9-14 \star$ & M & .4 & 5 & .8 & .05 & .2 & - & - & 60 & 80 & $<20$ & - \\
\hline $318+$ & $43-9-14 *$ & $M$ & .4 & 5 & .8 & .05 & .2 & - & - & 60 & 80 & $<20$ & - \\
\hline $319 \div$ & $43-9-13 *$ & M & .1 & 6 & .4 & .02 & .4 & 100 & - & 100 & 40 & $<20$ & - \\
\hline 320 & $43-9-13 \star$ & $\mathrm{M}$ & .2 & 3 & .2 & .4 & .2 & - & - & 100 & 80 & 20 & - \\
\hline 321 & $43-9-13 *$ & $>5$ & .03 & 2 & .2 & .1 & .1 & - & - & 200 & 40 & $<20$ & 20 \\
\hline $322+$ & $43-9-13 *$ & 5 & .03 & 7 & .2 & 6 & .2 & 200 & - & - & 80 & 30 & - \\
\hline 323 & $43-9-24 *$ & M & 1 & 4 & .8 & .1 & .2 & 100 & 1,000 & 60 & 20 & - & - \\
\hline 324 & $43-9-24 *$ & $>5$ & .3 & 4 & .2 & .1 & .3 & - & 4,000 & 200 & 40 & $<20$ & 20 \\
\hline $325+$ & $43-9-24 *$ & 4 & .3 & 5 & .8 & .2 & .2 & 200 & - & 60 & 40 & 20 & - \\
\hline 326 & 43- 9-24* & 5 & .1 & 4 & .6 & .1 & .2 & 100 & 1,000 & 60 & 160 & - & - \\
\hline $327+$ & $43-9-24 *$ & M & .06 & 3 & .4 & .05 & .2 & 200 & - & 60 & 20 & 20 & - \\
\hline $328+$ & $43-9-24 \star$ & 4 & .5 & 4 & 1.5 & .2 & .2 & 100 & 1,000 & 60 & 80 & - & - \\
\hline $329+$ & $43-8-19 *$ & $>5$ & .1 & 3 & .2 & 2 & .2 & $<100$ & 4,000 & 200 & 60 & $<20$ & 20 \\
\hline $330 \div$ & $43-8-19 *$ & 4 & .06 & 3 & .1 & .1 & .2 & 100 & - & 300 & 60 & 30 & 20 \\
\hline $331+$ & $43-8-19 *$ & 5 & .3 & 2 & .2 & .2 & .3 & 100 & - & 200 & 40 & $<20$ & 20 \\
\hline $332 \div$ & $43-8-19 *$ & $M$ & .2 & 4 & .4 & .4 & .2 & 200 & 1,000 & 100 & 160 & 20 & - \\
\hline $333 t$ & $43-9-24 *$ & $M$ & 2 & 6 & 1.5 & .2 & .4 & 200 & 1,000 & 60 & 40 & 30 & - \\
\hline $334 i$ & $43-9-24 \star$ & $\mathrm{M}$ & .3 & M & .8 & .4 & .8 & 100 & - & 100 & 80 & 20 & - \\
\hline $335 t$ & $43-9-24 *$ & $M$ & .4 & 7 & .8 & .05 & .2 & 200 & - & 100 & 160 & 30 & - \\
\hline $336 t$ & $43-9-24 \star$ & 5 & .4 & 6 & .8 & .05 & .1 & 100 & - & 60 & 80 & - & - \\
\hline $337+$ & $43-8-30 \star$ & 5 & .1 & 3 & .2 & .8 & .2 & 100 & - & 100 & 50 & - & - \\
\hline 338 & $43-8-30 *$ & $>5$ & 4 & 3 & 4 & .2 & .2 & - & - & 100 & 80 & - & - \\
\hline 339 & $43-8-30 *$ & $>5$ & 1 & 3 & 2 & .2 & .2 & - & - & 70 & 40 & - & - \\
\hline 340 & $43-8-30 \star$ & $>5$ & 1 & 3 & 2 & .2 & .2 & - & - & 70 & 50 & - & - \\
\hline 341 & $43-8-30 *$ & $>5$ & 2 & 3 & 2 & .2 & .2 & - & - & 30 & 50 & - & - \\
\hline $342 \div$ & $43-8-30 *$ & .7 & $M$ & 2 & .8 & .4 & .02 & - & 1,000 & - & 40 & - & - \\
\hline 343 & $43-8-30 *$ & 5 & 4 & 4 & 1.5 & .1 & .2 & 100 & 1,000 & 30 & 20 & - & - \\
\hline $344+$ & $43-8-30^{*}$ & 5 & 2 & 4 & 1 & .05 & .2 & 100 & 1,000 & 30 & 40 & - & - \\
\hline $345 t$ & $43-8-30 *$ & $>5$ & 1 & 5 & 1 & .1 & .2 & 100 & - & 100 & 80 & - & - \\
\hline 346 & $43-8-30 *$ & 5 & $>4$ & 5 & .8 & .4 & .2 & 200 & 4,000 & 60 & 40 & - & - \\
\hline 347 & $43-8-30 \star$ & $>5$ & 2 & 4 & 1 & .05 & .2 & - & - & 60 & 80 & - & - \\
\hline 348 & $43-8-30 \star$ & $>5$ & 1 & 5 & 1 & .05 & .2 & 100 & - & 30 & 40 & - & - \\
\hline $349+$ & $43-8-30 *$ & $>5$ & 2 & 4 & 1 & .1 & .2 & 100 & - & 30 & 40 & - & - \\
\hline 350 & $43-8-30$ * & $>5$ & 2 & 3 & .2 & .2 & .2 & - & - & 70 & 50 & - & - \\
\hline 351 & $43-8-30 *$ & $>5$ & 2 & 3 & .2 & .2 & .2 & - & - & 70 & 50 & - & - \\
\hline 352 & $43-8-30 *$ & $>5$ & .3 & 3 & .2 & .2 & .2 & - & - & 30 & 50 & - & - \\
\hline 353 & $43-8-30 *$ & $>5$ & 1 & 6 & 1 & .4 & .2 & 100 & - & 60 & 80 & - & - \\
\hline 354 & $43-9-25 *$ & 2 & .5 & 1 & .8 & .2 & .1 & - & - & 60 & 80 & - & - \\
\hline 355 & $43-9-25 *$ & .3 & M & .4 & .6 & .1 & .02 & - & - & 60 & 20 & - & - \\
\hline 356 & 43- 9-36* & 5 & .2 & 2 & .4 & .1 & .2 & 100 & 1,000 & 60 & 40 & - & - \\
\hline 357 & $43-9-36 *$ & 4 & .03 & 2 & .2 & .05 & .1 & 100 & 1,000 & 60 & 20 & - & - \\
\hline 358 & $43-9-36 \star$ & .7 & .02 & 1 & .03 & .05 & .02 & - & - & 60 & 20 & - & - \\
\hline $361+$ & $43-9-22 \star$ & 5 & .06 & 5 & .8 & .05 & .2 & 300 & - & 40 & 40 & 70 & - \\
\hline 362 & $43-9-22 \star$ & 5 & .06 & 3 & .6 & .05 & .1 & 200 & - & $<30$ & 20 & 30 & - \\
\hline
\end{tabular}


CONTIGUOUS AREAS, UNCOMPAHGRE PRIMITIVE AREA, COLO. El19

contiguous to the Uncompahgre Primitive Area-Continued

\begin{tabular}{|c|c|c|c|c|c|c|c|c|c|c|}
\hline \multirow[b]{3}{*}{ Sample } & \multicolumn{4}{|c|}{$\begin{array}{l}\text { Semiquantitative spectrographic } \\
\text { analyses--Continued }\end{array}$} & \multirow{2}{*}{\multicolumn{2}{|c|}{$\frac{\text { Fire assay }}{o z / \text { ton }}$}} & \multicolumn{3}{|c|}{$\begin{array}{c}\text { Atomic absorption } \\
\text { analyses }\end{array}$} & \multirow{3}{*}{ Sample data } \\
\hline & \multicolumn{4}{|c|}{$\mathrm{ppm}$} & & & \multicolumn{3}{|c|}{ percent } & \\
\hline & $\begin{array}{c}\mathrm{Pb} \\
(100)\end{array}$ & $\begin{array}{c}\mathrm{Sr} \\
(1,000)\end{array}$ & $\begin{array}{c}\mathrm{Zn} \\
(1,000)\end{array}$ & $\begin{array}{c}\mathrm{Zr} \\
(70)\end{array}$ & $\mathrm{Au}$ & $\overline{\mathrm{Ag}}$ & $\mathrm{Cu}$ & $\mathrm{Pb}$ & $2 \mathrm{n}$ & \\
\hline 301 & 100 & - & - & - & - & - & na & na & na & Outcrop-ch1p-8 $\mathrm{ft}$. \\
\hline 302 & 100 & - & - & 100 & - & - & na & na & na & Outcrop-d1ke-chip-12 ft. \\
\hline 303 & 700 & - & - & 70 & $\mathrm{~T}$ & 0.2 & na & na & na & Adit-dump ( 50 tons)-grab \\
\hline 304 & - & - & - & - & $\mathrm{T}$ & - & na & na & na & Adit-face-chip-4 ft. \\
\hline 305 & 100 & - & 2,000 & 200 & $\mathrm{~T}$ & $\mathrm{~T}$ & na & na & 0.08 & Ad1t-caved stope-grab \\
\hline 306 & 1,000 & - & 3,000 & - & - & .1 & na & .17 & .37 & Ad1t-face-vein-ch1p-3 ft. \\
\hline 307 & 700 & - & 1,000 & 70 & - & - & na & .03 & .05 & Adit-face-vein-chip-1 ft. \\
\hline 308 & 700 & - & 1,000 & 70 & $\mathrm{~T}$ & .1 & na & .02 & .08 & Adit-face-vein-chip-2 ft. \\
\hline 309 & 1,000 & - & 2,000 & 70 & $\mathrm{~T}$ & .1 & na & .05 & .17 & Adit-face-muck-grab \\
\hline 310 & 200 & $<1,000$ & - & 70 & - & .1 & na & na & na & Pit-dump ( 5 tons)-grab \\
\hline $311+$ & 1,000 & 1,000 & 3,000 & 70 & - & .6 & 0.25 & .72 & .17 & Ad1 t-dump ( 30 tons)-grab \\
\hline $312 \dagger$ & 3,000 & - & 10,000 & 70 & $\mathrm{~T}$ & 1.2 & .01 & .48 & 1.98 & Ad1 t-face-ve1n-ch1p-2.5 ft. \\
\hline $313 \dagger$ & 20,000 & - & 30,000 & 70 & $\mathrm{~T}$ & 14.4 & .04 & .77 & .80 & Ad1 t-dump $(1,200$ cons $)-g r a b$ \\
\hline 314 & - & $<1,000$ & - & 100 & - & .1 & na & na & na & P1t-vein-chip-4 ft. \\
\hline 315 & 200 & - & - & 100 & - & $\mathrm{T}$ & na & na & na & Ad1t-face-vein-chip-3 ft. \\
\hline $316+$ & 10,000 & - & 10,000 & 100 & $\mathrm{~T}$ & .1 & na & .24 & .48 & Shaft-drift-face-vein-chip- 4 ft. \\
\hline $317 \dagger$ & 400 & - & 1,000 & 300 & $\mathrm{~T}$ & .2 & na & na & .06 & Outcrop-ve1n-chip-6 ft. \\
\hline $318 \%$ & 400 & - & 1,000 & 300 & - & .2 & na & na & .02 & P1t-vein-chip-g ft. \\
\hline $319+$ & 700 & - & 1,000 & 300 & $\mathrm{~T}$ & - & na & .01 & .01 & Adit-dump ( 300 tons)-grab \\
\hline 320 & 700 & - & 1,000 & 100 & $\mathbf{T}$ & .1 & na & .10 & .13 & Adit-face-ve1n-chip-4 ft. \\
\hline 321 & 400 & - & - & 70 & $\mathrm{~T}$ & .2 & na & na & na & Outcrop (talus) $-\mathrm{grab}-300 \mathrm{ft}$. \\
\hline $322+$ & 3,000 & - & 2,000 & 100 & .01 & .3 & na & .14 & .08 & Pit-vein-ch1p-14 ft. \\
\hline 323 & 200 & - & - & 300 & $\mathbf{T}$ & .2 & na & na & na & P1t-dump (60 tons)-grab \\
\hline 324 & 100 & - & - & 70 & $\mathrm{~T}$ & .2 & na & na & na & Pit-vein-ch1p-0.75 ft. \\
\hline $325 t$ & 400 & - & - & 100 & - & .1 & na & na & na & Pit-dump (10 tons)-grab \\
\hline 326 & 200 & - & - & 300 & $\mathrm{~T}$ & $\mathrm{~T}$ & .01 & na & na & Ad1t-dump (40 tons)-grab \\
\hline $327+$ & 400 & - & - & 100 & $\mathrm{~T}$ & .1 & na & na & na & Outcrop-veln-chip-4 ft. \\
\hline $328 i$ & 200 & - & - & 100 & $\mathbf{T}$ & .1 & na & na & na & P1t-dump (100 tons)-grab \\
\hline $329+$ & 10,000 & - & - & 70 & .01 & .6 & na & .31 & na & Adit-wall-vein-chip-1.75 ft. \\
\hline $330 \div$ & 10,000 & - & - & 70 & .01 & .3 & na & .40 & na & Adit-back-ve1n-ch1p-3.5 ft. \\
\hline $331 \dagger$ & 100 & - & - & 70 & - & .2 & na & na & na & Adit-wa11-vein-chip-2.5 ft. \\
\hline $332 \dagger$ & 8,000 & - & 1,000 & 300 & .01 & .5 & .01 & .32 & .07 & Ad1t-dump (250 tons)-grab \\
\hline $333+$ & 600 & - & - & 300 & - & .3 & na & na & na & Do. \\
\hline $334+$ & 200 & - & - & 300 & $\mathrm{~T}$ & .2 & na & na & na & Adit-back-vein-chip-2.5 ft. \\
\hline $335 \dagger$ & 400 & - & - & 300 & $\mathbf{T}$ & .1 & .01 & na & na & Ad1t-back-vein-ch $1 \mathrm{p}-1.5 \mathrm{ft}$. \\
\hline $336 \div$ & 400 & - & - & 300 & - & .1 & na & na & na & P1t-dump (200 tons)-grab \\
\hline $337+$ & 900 & - & - & 70 & - & $\mathrm{T}$ & na & na & na & Outcrop-ve1n-ch1p-12 ft. \\
\hline 338 & - & - & - & 100 & - & .2 & na & na & na & Adit-dump ( 75 tons)-grab \\
\hline 339 & - & - & - & 100 & - & .1 & na & na & na & Adit-dump ( 100 tons) $-8 \mathrm{rab}$ \\
\hline 340 & - & - & - & 70 & - & $\mathrm{T}$ & na & na & na & Adit-dump ( 40 tons)-grab \\
\hline 341 & - & - & - & 100 & - & - & na & na & na & Adit-dump (700 tons)-grab \\
\hline $342 \div$ & 100 & 1,000 & 1,000 & 70 & - & - & na & na & na & Adit-back-vein-ch1p-i in. \\
\hline 343 & - & - & - & 100 & - & - & na & na & na & Adit-caved stope-grab \\
\hline $344 \%$ & 100 & - & - & 70 & - & - & na & na & na & Adit-back-vein-chip-6 ft. \\
\hline $345 r$ & 100 & - & - & 100 & - & - & na & na & na & Adit-face-chip-3.5 ft. \\
\hline 346 & 100 & - & - & 100 & - & - & na & na & na & Adit-wall-ve1n-chtp-2.5 ft. \\
\hline 347 & 100 & 1,000 & - & 70 & - & - & na & na & na & P1t-dump (20 tons)-grab \\
\hline 348 & 100 & 1,000 & - & 70 & - & - & na & na & na & Pit-dump ( 35 tons)-grab \\
\hline $349 \dagger$ & 100 & 1,000 & - & 70 & - & - & na & na & na & Pit-dump ( 20 tons) $-g r a b$ \\
\hline 350 & 100 & - & - & 100 & - & $\mathrm{T}$ & na & na & na & Ad1t-portal-floor-specimen \\
\hline 351 & - & - & - & 100 & - & .2 & na & na & na & Pit-dump (15 tons)-grab \\
\hline 352 & - & - & - & 70 & - & .1 & na & na & na & Outcrop-vein-chip- $2.5 \mathrm{ft}$ \\
\hline 353 & 400 & - & - & 100 & .02 & 1.2 & na & na & na & Ad1t-dump ( 400 tons)-grab \\
\hline 354 & 100 & - & - & - & $\mathbf{T}$ & $\mathrm{T}$ & na & na & na & Adit-dump (40 tons)-grab \\
\hline 355 & - & - & - & - & $\mathrm{T}$ & .2 & na & na & na & Ad1t-dump-specimen \\
\hline 356 & 200 & - & - & 300 & $\mathrm{~T}$ & .1 & na & na & na & Trench-dump ( 20 tons)-grab \\
\hline 357 & 200 & - & - & 100 & - & .2 & na & na & na & P1t-dump (20 tons)-grab \\
\hline 358 & 200 & - & - & $<70$ & - & .1 & na & na & na & Pit-stockpile(200 lb.)-grab \\
\hline 361 & $<100$ & - & - & 70 & - & - & na & na & na & Adit-face-vein-chip-0.5 ft. \\
\hline 362 & $<100$ & - & - & 70 & - & - & na & na & na & Adit-dump ( 15 tons)-grab \\
\hline
\end{tabular}


TABLE 11.-Analyses of samples from study areas

\begin{tabular}{|c|c|c|c|c|c|c|c|c|c|c|c|c|c|}
\hline \multirow[b]{3}{*}{ Sample } & \multirow[b]{3}{*}{$\begin{array}{l}\text { Location } \\
\text { T.R. S. }\end{array}$} & \multicolumn{12}{|c|}{ Semiquantitative spectrographic analyses } \\
\hline & & \multicolumn{6}{|c|}{ percent } & \multicolumn{6}{|c|}{$\mathrm{ppm}$} \\
\hline & & $\begin{array}{c}\mathrm{Al} \\
(.003) \\
\end{array}$ & $\begin{array}{c}\mathrm{Ca} \\
(.02) \\
\end{array}$ & $\begin{array}{c}\mathrm{Fe} \\
(.004) \\
\end{array}$ & $\begin{array}{c}\mathrm{Mg} \\
(.004) \\
\end{array}$ & $\begin{array}{c}\mathrm{Mn} \\
(.003) \\
\end{array}$ & $\begin{array}{c}\mathrm{Ti} \\
(.001) \\
\end{array}$ & $\begin{array}{c}\text { B } \\
(100)\end{array}$ & $\begin{array}{c}\mathrm{Ba} \\
(1,000) \\
\end{array}$ & $\begin{array}{c}\mathrm{Cr} \\
(30) \\
\end{array}$ & $\begin{array}{c}\mathrm{Cu} \\
(20) \\
\end{array}$ & $\begin{array}{c}\text { Mo } \\
(20) \\
\end{array}$ & $\begin{array}{c}\mathrm{Ni} \\
(20) \\
\end{array}$ \\
\hline $\begin{array}{l}363 \\
364 \\
365 \\
366 \\
367\end{array}$ & $\begin{array}{l}43-9-21 * \\
43-9-16 * \\
43-9-9 \star \\
43-9-9 \star \\
43-9-9 *\end{array}$ & $\begin{array}{l}>5.0 \\
5 \\
5 \\
M \\
3\end{array}$ & $\begin{array}{l}4.0 \\
1 \\
2 \\
.03 \\
.03\end{array}$ & $\begin{array}{l}5.0 \\
3 \\
3 \\
2 \\
3\end{array}$ & $\begin{array}{r}2.0 \\
.8 \\
.4 \\
.1 \\
.3\end{array}$ & $\begin{array}{l}0.2 \\
.05 \\
.2 \\
.01 \\
.03\end{array}$ & $\begin{array}{r}0.2 \\
.2 \\
.2 \\
.1 \\
.1\end{array}$ & $\begin{array}{c}100 \\
- \\
100 \\
- \\
-\end{array}$ & $\begin{array}{l}- \\
- \\
- \\
-\end{array}$ & $\begin{array}{r}400 \\
30 \\
60 \\
60 \\
300\end{array}$ & $\begin{array}{r}60 \\
1,300 \\
80 \\
40 \\
80\end{array}$ & $\begin{array}{r}- \\
- \\
30 \\
20 \\
-\end{array}$ & $\begin{array}{r}80 \\
20 \\
20\end{array}$ \\
\hline $\begin{array}{l}368 \\
369 \\
370 \\
371 \\
372\end{array}$ & $\begin{array}{l}43-9-9 * \\
43-9-9 * \\
43-9-8 * \\
43-9-8 * \\
43-9-8 *\end{array}$ & $\begin{array}{r}3 \\
3 \\
>5 \\
3 \\
>5\end{array}$ & $\begin{array}{l}.1 \\
.1 \\
.03\end{array}$ & $\begin{array}{l}2 \\
2 \\
7 \\
6 \\
4\end{array}$ & $\begin{array}{l}.3 \\
.3 \\
.1 \\
.4 \\
.8\end{array}$ & $\begin{array}{l}.02 \\
.03 \\
.1 \\
.1 \\
.05\end{array}$ & $\begin{array}{l}.1 \\
.1 \\
.2 \\
.2 \\
.1\end{array}$ & $\begin{array}{c}- \\
- \\
200 \\
500 \\
100\end{array}$ & $\begin{array}{l}- \\
- \\
- \\
-\end{array}$ & $\begin{array}{r}100 \\
100 \\
60 \\
60 \\
60\end{array}$ & $\begin{array}{l}40 \\
40 \\
40 \\
20 \\
40\end{array}$ & $\begin{array}{l}- \\
- \\
- \\
-\end{array}$ & $\begin{array}{l}20 \\
- \\
- \\
-\end{array}$ \\
\hline $\begin{array}{l}373 \\
374 \\
375 \\
376 \\
377\end{array}$ & $\begin{array}{l}43-9-18 * \\
43-9-18 * \\
44-10-36 * \\
44-10-36 * \\
43-9-30 *\end{array}$ & $\begin{array}{r}>5 \\
5 \\
>5 \\
>5 \\
M\end{array}$ &.$_{2^{.3}}^{.3}$ & $\begin{array}{l}3 \\
3 \\
3 \\
3 \\
5\end{array}$ & $\begin{array}{l}3 \\
5 \\
3 \\
3 \\
1.5\end{array}$ & $\begin{array}{l}.2 \\
.1 \\
.2 \\
.1 \\
.1\end{array}$ & $\begin{array}{l}.2 \\
.09 \\
.2 \\
.2 \\
.2\end{array}$ & $\begin{array}{l}- \\
- \\
- \\
-\end{array}$ & $\begin{array}{l}- \\
- \\
- \\
-\end{array}$ & $\begin{array}{r}500 \\
300 \\
500 \\
70 \\
40\end{array}$ & $\begin{array}{r}80 \\
600 \\
80 \\
40 \\
40\end{array}$ & $\begin{array}{l}- \\
- \\
- \\
-\end{array}$ & $\begin{array}{l}- \\
- \\
- \\
-\end{array}$ \\
\hline $\begin{array}{l}378 \\
379 \\
380 \\
381 \\
382+\end{array}$ & $\begin{array}{l}43-9-30 \star \\
43-9-30 * \\
43-9-30 * \\
44-10-25 * \\
44-10-25 *\end{array}$ & $\begin{array}{l}M \\
M \\
4 \\
4 \\
M\end{array}$ & $\begin{array}{l}4 \\
4 \\
1 \\
.5 \\
.5\end{array}$ & $\begin{array}{l}7 \\
6 \\
2 \\
2 \\
4\end{array}$ & $\begin{array}{l}1.5 \\
1.5 \\
1 \\
.2 \\
.4\end{array}$ & $\begin{array}{l}.1 \\
.1 \\
.1 \\
.03 \\
.1\end{array}$ & $\begin{array}{l}.4 \\
.4 \\
.1 \\
.2 \\
.2\end{array}$ & $\begin{array}{c}- \\
- \\
- \\
- \\
<100\end{array}$ & $\begin{array}{c}<1,000 \\
<1,000 \\
- \\
- \\
1,000\end{array}$ & $\begin{array}{r}40 \\
40 \\
30 \\
200 \\
-\end{array}$ & $\begin{array}{l}40 \\
40 \\
20 \\
40 \\
20\end{array}$ & $\begin{array}{r}- \\
<20 \\
<20 \\
<20 \\
-\end{array}$ & $\begin{array}{l}- \\
- \\
20 \\
20 \\
-\end{array}$ \\
\hline $\begin{array}{l}383 \\
384 \dagger \\
385 \\
386 \\
387\end{array}$ & $\begin{array}{l}44-10-25 * \\
44-10-25 * \\
43-10-10 * \\
43-10-10 * \\
43-10-10 *\end{array}$ & $\begin{array}{r}>5 \\
M \\
M \\
5 \\
3\end{array}$ & $2_{1.5}^{.5}$ & $\begin{array}{l}2 \\
4 \\
4 \\
3 \\
2\end{array}$ & $\begin{array}{r}.2 \\
.4 \\
1.5 \\
.8 \\
1.5\end{array}$ & $\begin{array}{l}.03 \\
.1 \\
.05 \\
.02 \\
.05\end{array}$ & $\begin{array}{l}.2 \\
.2 \\
.2 \\
.1 \\
.05\end{array}$ & $\begin{array}{c}- \\
<100 \\
- \\
- \\
-\end{array}$ & $\begin{array}{c}- \\
1,000 \\
- \\
- \\
-\end{array}$ & $\begin{array}{r}200 \\
- \\
- \\
60\end{array}$ & $\begin{array}{r}40 \\
40 \\
600 \\
1,300 \\
80\end{array}$ & $\begin{array}{r}<20 \\
- \\
60 \\
30 \\
-\end{array}$ & $\begin{array}{l}20 \\
- \\
- \\
- \\
-\end{array}$ \\
\hline $\begin{array}{l}388+ \\
389 \\
390\end{array}$ & $\begin{array}{l}43-10-10 * \\
43-10-10 * \\
43-10-26\end{array}$ & $\begin{array}{l}M \\
3 \\
.3\end{array}$ & $M^{.5}$ & $\begin{array}{l}3 \\
6 \\
.1\end{array}$ & $\begin{array}{l}.8 \\
.4 \\
.4\end{array}$ & $\begin{array}{l}.02 \\
.02 \\
.05\end{array}$ & $\begin{array}{l}.2 \\
.05 \\
.01\end{array}$ & $\begin{array}{c}100 \\
- \\
-\end{array}$ & $\begin{array}{l}- \\
-\end{array}$ & $\begin{array}{l}- \\
- \\
-\end{array}$ & $\begin{array}{r}600 \\
160 \\
20\end{array}$ & $\begin{array}{r}30 \\
- \\
-\end{array}$ & $\begin{array}{l}- \\
-\end{array}$ \\
\hline $\begin{array}{l}1 . \\
6 . \\
31 . \\
32 . \\
33 . \\
34 . \\
35 . \\
37 . \\
42 . \\
49 . \\
50 . \\
51 . \\
52 . \\
53 . \\
59 . \\
61 . \\
62 . \\
68 .\end{array}$ & $\begin{array}{l}400 \mathrm{ppm} \mathrm{V} \\
100 \mathrm{ppm} \mathrm{Co}, \\
17.4 \% \mathrm{Ba}, 0 \\
0.03 \% \mathrm{Sb} \\
1.7 \% \mathrm{Ba}, 0 . \\
38.7 \% \mathrm{Ba}, 0 \\
0.06 \% \mathrm{Sb} \\
0.68 \% \mathrm{Sb} \\
0.07 \% \mathrm{Sb} \\
17 \% \mathrm{Ba}, 0.0 \\
0.05 \% \mathrm{Sb} \\
0.05 \% \mathrm{Sb} \\
7.21 \% \mathrm{Ba}, 5 \\
9.85 \% \mathrm{Ba}, 0 \\
50 \mathrm{ppm} \mathrm{Sn} \\
<0.01 \% \mathrm{U}_{3} 0_{8} \\
0.10 \% \mathrm{U}_{30} 8 \\
100 \mathrm{ppm} \mathrm{Bi} \\
31.9 \% \mathrm{Mn}^{2}, 3 \\
0.06 \% \mathrm{Mo}, \\
900 \mathrm{ppm} \mathrm{V}\end{array}$ & $\begin{array}{l}30 \mathrm{ppm} \mathrm{Sc} \\
.03 \% \mathrm{Sb} \\
06 \% \mathrm{Sb} \\
.16 \% \mathrm{Sb} \\
\\
5 \% \mathrm{Sb} \\
0 \mathrm{ppm} \mathrm{Sn} \\
.10 \% \mathrm{Sb}, \\
00 \mathrm{ppm} \mathrm{Co} \\
300 \mathrm{ppm}\end{array}$ & & & $\begin{array}{l}\text { 71. } \\
72 . \\
75 . \\
76 . \\
77 . \\
78 . \\
79 . \\
80 . \\
83 . \\
84 . \\
86 . \\
98 . \\
101 . \\
103 . \\
104 . \\
106 . \\
110 . \\
115 .\end{array}$ & $\begin{array}{r}20 \mathrm{ppm} \mathrm{Sn} \\
40 \mathrm{ppm} \mathrm{Sn}, \\
9.11 \% \mathrm{Mn}, \\
500 \mathrm{ppm} \\
100 \mathrm{ppm} \mathrm{V} \\
<0.01 \% \mathrm{U}_{3} \mathrm{O} \\
40 \mathrm{ppm} \mathrm{Co} \\
<0.01 \% \mathrm{U}_{3} \mathrm{O} \\
0.01 \% \mathrm{U}_{3} \mathrm{O}_{8} \\
0.01 \% \mathrm{U}_{3} \mathrm{O}_{8} \\
40 \mathrm{ppm} \mathrm{Be} \\
40 \mathrm{ppm} \mathrm{Be} \\
0.07 \% \mathrm{Sb} \\
0.05 \% \mathrm{Sb} \\
0.04 \% \mathrm{Bi} \\
10.0 \mathrm{ppm} \mathrm{Bi} \\
<0.01 \% \mathrm{Sb} \\
<0.01 \% \mathrm{U}_{3} \mathrm{O} \\
0.10 \% \mathrm{U}_{3} \mathrm{O}_{8}\end{array}$ & $\begin{array}{l}100 \mathrm{ppm} \\
80 \mathrm{ppm} \mathrm{Sn} \\
\mathrm{V} \\
8 \\
8 \\
3 \\
3 \\
8 \\
3\end{array}$ & &. & $\begin{array}{l}117 . \\
120 . \\
129 . \\
130 . \\
131 . \\
132 . \\
136 . \\
149 . \\
156 . \\
160 . \\
165 . \\
166 . \\
168 . \\
184 . \\
189 . \\
191 . \\
193 . \\
195 . \\
196 .\end{array}$ & $\begin{array}{l}0.07 \% \mathrm{U}_{3} \mathrm{O} \\
30 \mathrm{ppm} \mathrm{Sn}, \\
100 \mathrm{ppm} \mathrm{B1} \\
0.04 \% \mathrm{B1} \\
52.6 \% \mathrm{Fe}, \\
30.2 \% \mathrm{Fe} \text {, } \\
<0.01 \% \mathrm{U}_{3} \mathrm{C} \\
52.2 \% \mathrm{Fe} \\
300 \mathrm{ppm} \mathrm{Sc} \\
4.2 \% \mathrm{Ba} \\
100 \mathrm{pm} \mathrm{V} \mathrm{V} \\
100 \mathrm{pm} \mathrm{V} \mathrm{V} \\
0.04 \% \mathrm{~W} \\
0.07 \% \mathrm{Sb} \\
0.14 \% \mathrm{As}, \\
0.05 \% \mathrm{Sb} \\
0.03 \% \mathrm{Sb} \\
50 \mathrm{ppm} \mathrm{Sc} \\
0.04 \% \mathrm{Sb}\end{array}$ & $\begin{array}{l}0_{8} \\
100 \mathrm{ppm} \\
1 \\
1 \\
, 800 \mathrm{ppm} \\
800 \mathrm{ppm} \\
3^{0} 800 \mathrm{ppm} \\
4 \\
0.25 \%\end{array}$ & $\begin{array}{l}\text { m } v \\
m v \\
\text { m } v\end{array}$ \\
\hline
\end{tabular}


CONTIGUOUS AREAS, UNCOMPAHGRE PRIMITIVE AREA, COLO. E121

contiguous to the Uncompahgre Primitive Area-Continued

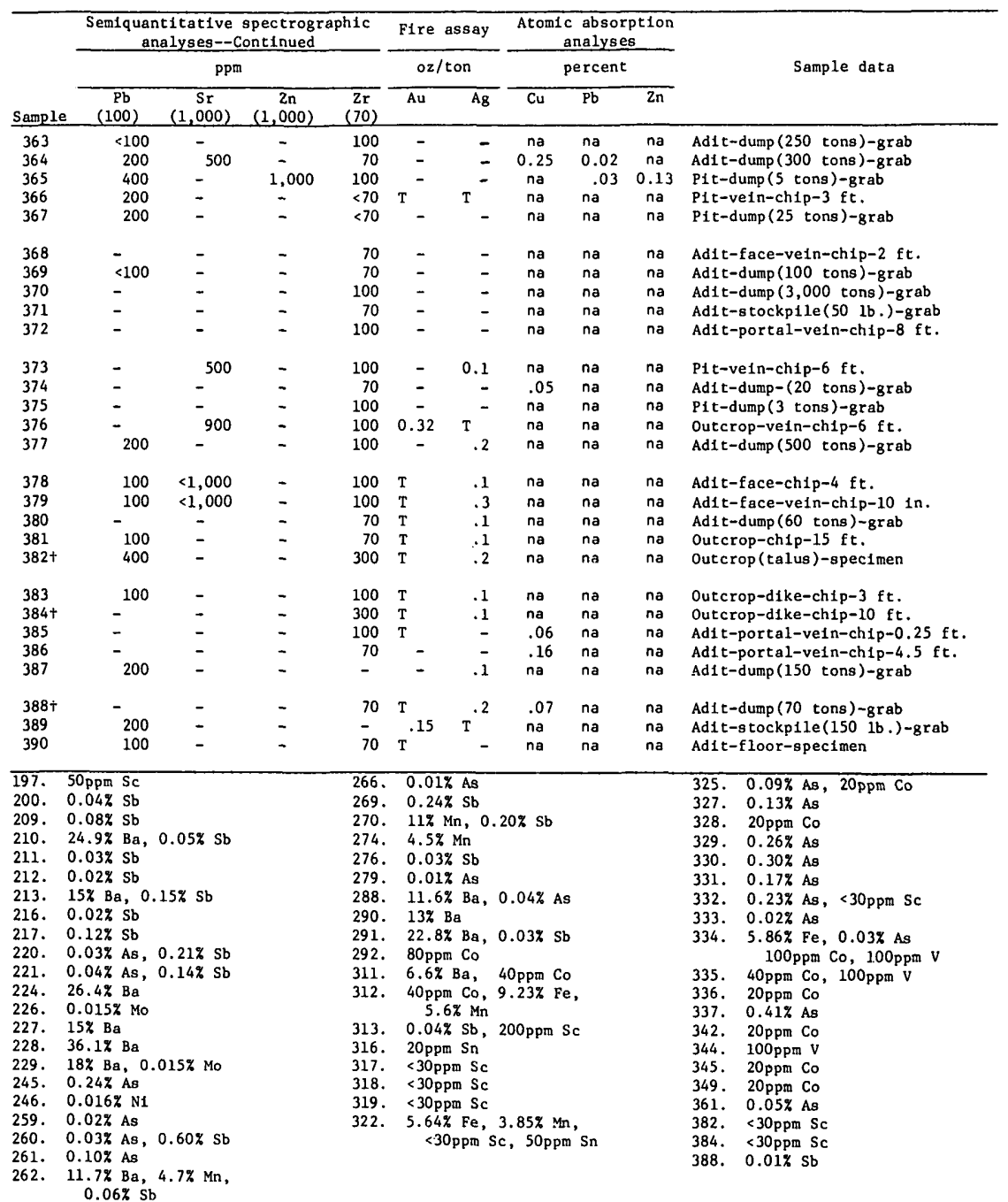





\section{INDEX}

[Page numbers of major references are in italic type]

A

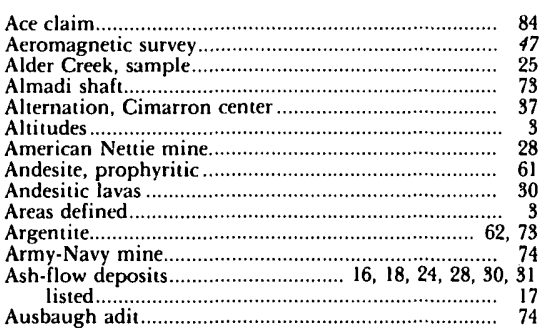

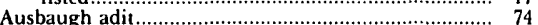

Bachelor adit

Bachelor caldera...

Bachelor mine...

28,79

(1) mine

Baldy Peak claim $39,62,73,80$

Barite veins, Corbett Creek

73,80
76

Basalt dike, Coal Creek.

Bear Gulch, sample

Beaver Creek, claims

Bertrandite.

Beryllium, El Paso Creek

Independence Gulch

Larson Creek

rhyolite intrusions

Beth claims.

Big Blue Creek

Bighorn Ridge, claims.

intrusive center

Bilk Creek Sandstone Member

Bill Hare Gulch

Black Girl mine

Black Girl vein

Blaine Basin, claim

Blaine mine

Blowout. See The Blowout.

Blue Creek.

Blue Lakes, claims

Blue Mesa Tuff.....

Britule Silver dump

Broken Hill, dike

intrusion

Building stone, Telluride

Burns Formation

elluride

C

Calcite-barite veins, Winchester Gulch

Calliope group..

Campbell Peak ...........

Capiol City mine....

Capitol City mine..............

aeromagnetic low.....

Carbonate Hill, claims

Carpenter Ridge Tuff

Carson Camp.........

mineralization.

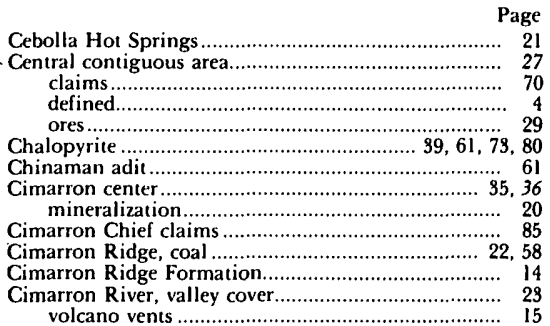

See also East Fork Cimarron River.

See also Middle Fork Cimarron River.

See also West Fork Cimarron River.

Cirnarron Volcano ................................. 15, 84, 37, 54

Coal Cimarron Ridge.

20,22

Deep Creek Mesa road $\ldots . . . . \ldots \ldots \ldots \ldots \ldots \ldots \ldots \ldots \ldots . . . . .22,58$

San Miguel River

Coal Creek, claims

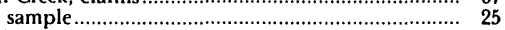

Coal-entry patents................................................ 58

Commercial activities ............................................. 4

Copper exploration.............................................. 58

Copper mineralization, Bighorn Ridge .................. 70

Matterhorn volcanic center.................................. 31

Copper test............................................................ 32

Copper-zinc anomaly....................................................... 32

Corbett Creek, claims.................................................. 61

Cornet Creek, adit ............................................................ 63

claims ....................................................... 62

Courthouse Creek, claims ....................................... 71

Courthouse mine ................................................... 57

Cow Creek .................................................................... 9

center ............................................................ 27

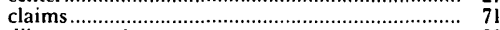

dikes, central area ............................................. 28

Cowboy adit

Cowboy adit .............................................................. 67

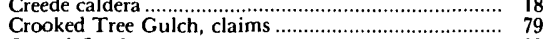

Crystal Creek............................................................ 99

Crystal Lake, landslide ..................................................... 99

Crystal Lake Tuff ................................................. 18, 40

Crystal Peak .................................................. 58, 54

Cutler Creek ......................................................... 28

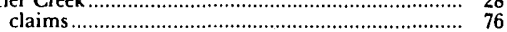

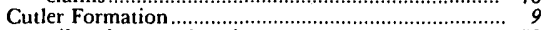

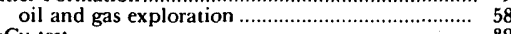

CxCu test.............

CxHM test ..................................................... 82

Czarina shaft .................................................................... 8

Dakota Sandstone ........................................... 13, 20 central area

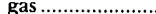

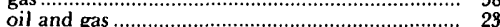

oil and gas .................................................... 29

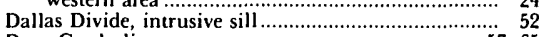

Deep Creek, limestone ........................................... 57, 65

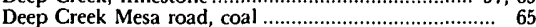

Dexter Creek................................................. 27, 29 


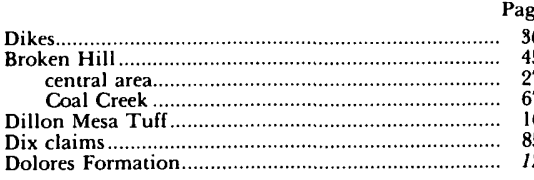

E

East Fork Cimarron River

$31,34,38,53$

Eastern contiguous area. claims. defined.

Economic appraisal

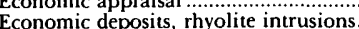

El Chaddai Ithrel claims

El Mahdi shaft

E] Paso Creek, claims.

plugs

samples......

upper, dike.

uranophane.

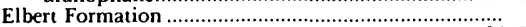

Elk Creek ..................................................... 34, 58

Engineer Mountain-Red Mountain Creek, veins............ 2

Entrada Sandstone.

Eureka Member

Exchange adit

Fall Creek

Firebox Creek

Fish Canyon Tuff

Fisher Quartz Latite.

Fluorine, rhyolite intrusions

Fluorite...

Forceman Creek claims

Fruitland Formation, coal.

Galen

$39,61,62,73,80$

Gas

accumulations exploration..

Geology, regional .

Geothermal energy

Glacial deposits..

Granodio itite, western area

Granodiorite porphyry

Granodioritic intrusive bodies.

Grayhead quadrangle

Greenback Mountain ...............

Gunnison River. See Lake Fork Gunnison River.

Hallie C. adit

Hayden Peak, claims$$
\text { veins }
$$

Henson Creek

claims.

North Fork

samples.

veins

34,53

34
80

40

43

46

62

22,58

G

Henson. Formation.

Hermosa Formation

Hidden Silver adit.

Hidden Treasure mine.

High Bridge Gulch.

Hot springs...

Hugh S. adit

Humboldt mine

Humboldt vein

\section{$\mathrm{H}$}

$\begin{array}{rr}7,80 \\ . & 23 \\ . & 20 \\ 58 \\ . . & 7 \\ . & 21 \\ . & 19 \\ 24 \\ 69 \\ . & 27 \\ . . & 5 \\ . & 26\end{array}$

Iron Mountain, stock...

Page

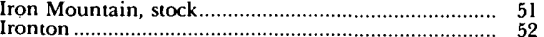

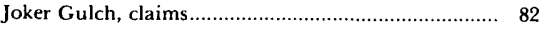

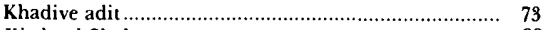

Kirtland Shale ................................................. 22

$\mathbf{L}$

La Garita caldera ................................................ 18

Laccolith, Cow Creek ........................................... 50

Lake City caldera .................................................. 19, 39

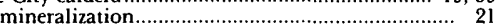

Lake Fork Formation ...................................... 15

Lake Fork Gunnison River, voicano vents................. I5

Landsliding, central area......................................... 27

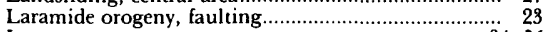

Larson center ..................................................... 34,36

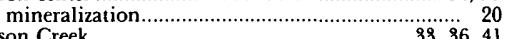

Larson Creek ......................................... 33, 36, 41 claims ....................................................... 83

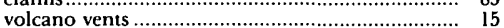

Larson volcano ............................................................ 54

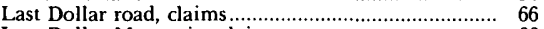

Last Dollar Mountain, claims .......................................... 66

Lead exploration................................................ $\quad 58$

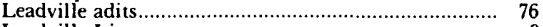

Leadville Limestone ............................................... 9

Leasing act minerals................................................ 58

Lemon Hot Springs ................................................ 22

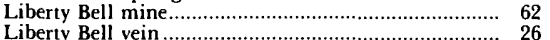

Liberty Bell vein ............................................. $\quad 26$

Limonite

Little Cimarron River.............................................. \$4, 58

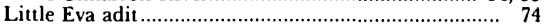

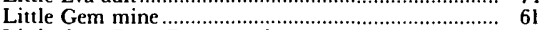

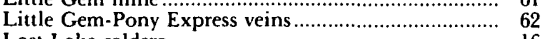

Lost Lake caldera ...................................................... 16

Lower Cow Creek center ............................................... 29

\section{M}

Magnetic susceptibility measurements ....................... 47

Mancos Shale ................................................... 13, 22 central area................................................... 27

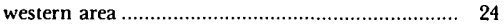

Manganese exploration......................................... 58

Mary Alice Creek ......................................................... 41

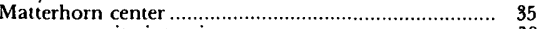
monzonite intrusion ................................................ 38 veins ........................................................... 21

Matterhorn Creek ............................................... 90 samples................................................ 81, 40

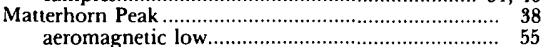
aeromagnetic low.............................................. 55

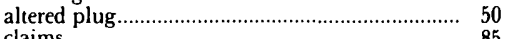

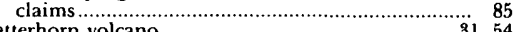

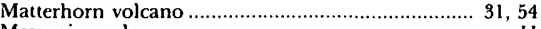

Mesozoic geology .................................................. II

Mesozoic sedimentary rocks......................................... $\quad 76$

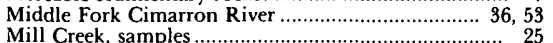

Mill Creek, samples .............................................. $\quad 25$

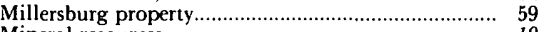

Mineral resources ................................................... 19

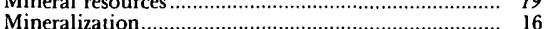

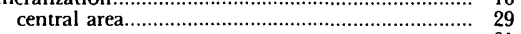
eastern area ..................................................... 31

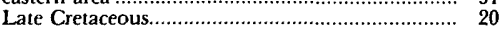
middle Tertiary ........................................ 20, 29

Ouray ............................................................. 20

San Juan caldera.......................................................

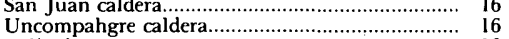

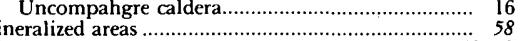

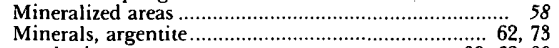
barite ................................................... $39,62,80$ bertrandite ....................................................... 46 chalcopyrite................................... $39,61,73,80$

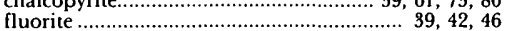

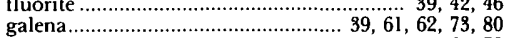

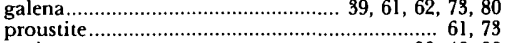
pyrite .............................................. $39,40,80$

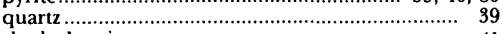

rhodochrosite .................................................... 41

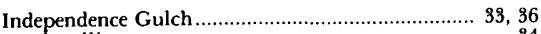

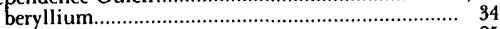

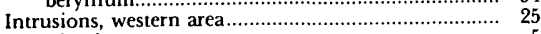
Investigations, present ........................................... 5

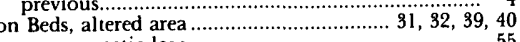
Beds, altered area
aeromagnetic low. 
Minerals-Continued sericite......

sphalerite...

Page

tetrahedrite

$39,61,62,79,80$

uranophane........... $39,61,62,73$

$42,44,46,84$

Mines...

See also specific mine names.

Mining claims.

Mining history

Modoc Creek ...........

Molybdenite, East Fork Cimarron River...

Molybdenum, Matterhorn center...... 98

Matterhorn Peak

Matterhorn volcanic center.....................................

prospects ....

rhyolite intrusions

western area

Molybdenum exploration

Molybdenum-lead anomaly

Monzonite stock, San Juan caldera................

Monzonitic intrusives....

Moonshine Park, claims

Pag

Pole Creek.

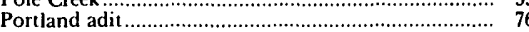

Portland mine ......................................................... 57

Precambrian quartzite ........................................., 52

Precambrian rocks …............................................. 7, 22

Prospects ............................................................ 58

Proustite ............................................................ 61, 79

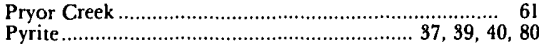

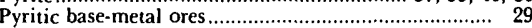

Q R

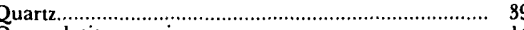

Quartz latite eruption ..............................................

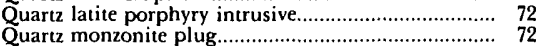

Radial dikes ................................................. 29, 34

Radium Hot Springs .......................................... 2]

Red Mountain Creek .............................................. 52

Red Mountain district, veins ........................................ 20

Red Mountain dome............................................... 21

References cited..................................................... 86

Rhodochrosite ............................................................... 4

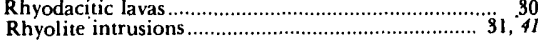

Cow Creek

Moss Rock Nos. $1-6$ placer claims ........................... 29

Mount Emma, veins

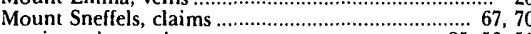
intrusive stock........................................... 25, 50, 5 I veins

Mountain Monarch adit ........................................... 69

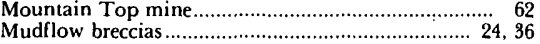

$$
\text { N, O }
$$

Near-vent facies flows, Sheep Mountain

Nellie Creek

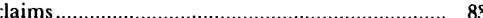

east fork, plug.................................................... 49

sill f..., plug................................................... 41

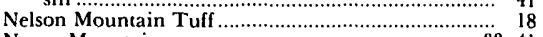

Neoga Mountain ................................................... 33, 41

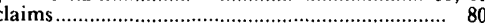

Neoga shaft .......................................................... 80

New York adit......................................................... 71

New York mine..............................................................

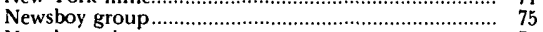

Newsboy mine.

Newsboy vein system.

Niobium, El Paso Creek

rhyolite intrusion........

North Fork Henson Creek samples.

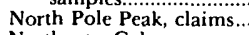

Northgate, Colo...........................................................

Oil

exploration.

Old Maid shaft

Orvis Hot Springs....................................................... 21

Ouray, Blowout. See The Blowout.

Ouray faule.

Ouray Limestone ............................................................... $\quad 52$

\section{$\mathbf{P}$}

Pack Basin, claims samples

Paleozoic sedimentary rocks

Patented claims

coal-entry.....

Pay Day placer claim.

Silver Jack mine area

Treasure Hill Spar claim

Pelican mine

economic deposits........................................ 45

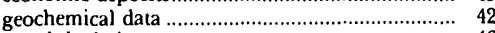

metal depletion ................................................... 46

Rhyolite porphyry, Lake City caldera.......................... 19

Rhyolitic ash-flows ................................................... 14

Ridgway faùlt .................................................... 29.

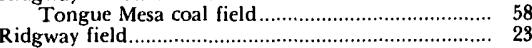

S

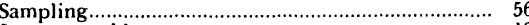

San Juan caldera ................................................. 18

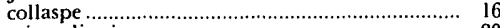

mineralization............................................ 20

monzonite stock ................................................ I9

San Juan Formation .............................................. 15

alternation....................................................... 28

westerentith

San Juan volcanic field ........................................... 7, 14

San Juan volcanic tield ............................................ 7, 18

San Luis caldera ................................................

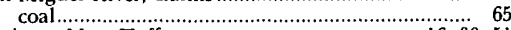

Sapinero Mesa Tuff .................................. 16, 30, 51

Senorita mine .................................................. 57, 75

Senorita vein system ...................................................... 61

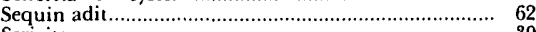

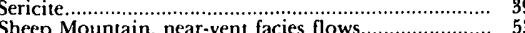

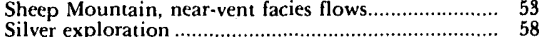

Silver Jack Dam, stone .............................................

Silver Jack mine................................... 15, 36, 37, 80, 85

Silver Queen adit .................................................... 71

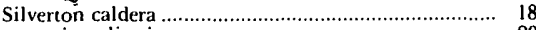

mineralization ............................................... 20

Slaughterhouse Gulch, aeromagnetic low .................. 55

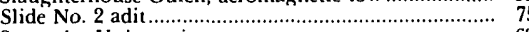

Smuggler-Union mine............................................. 62

Sneffels. See Mount Sneffels.

Soldier Creek ........................................................ $\$ 4$

Soldier Creek ...........................................................

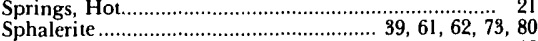

Spor Mountain, Utah .............................................. 46

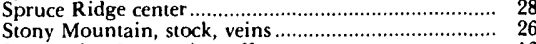

Storm King Mountain, tuff ................................... 16

Stream-sediment samples, central area..................... 28

eastern area ................................................ 31

western area .................................................... 25

Sugarloaf Rock .................................................... 41

Sultan Mountain................................................ 53

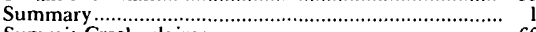

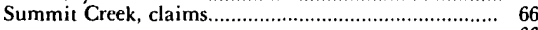

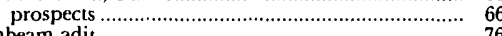

Sunbeam adit ......................................................... 76

Sunshine Mountain .................................................

Sunshine Peak Tuff .................................................. 19 


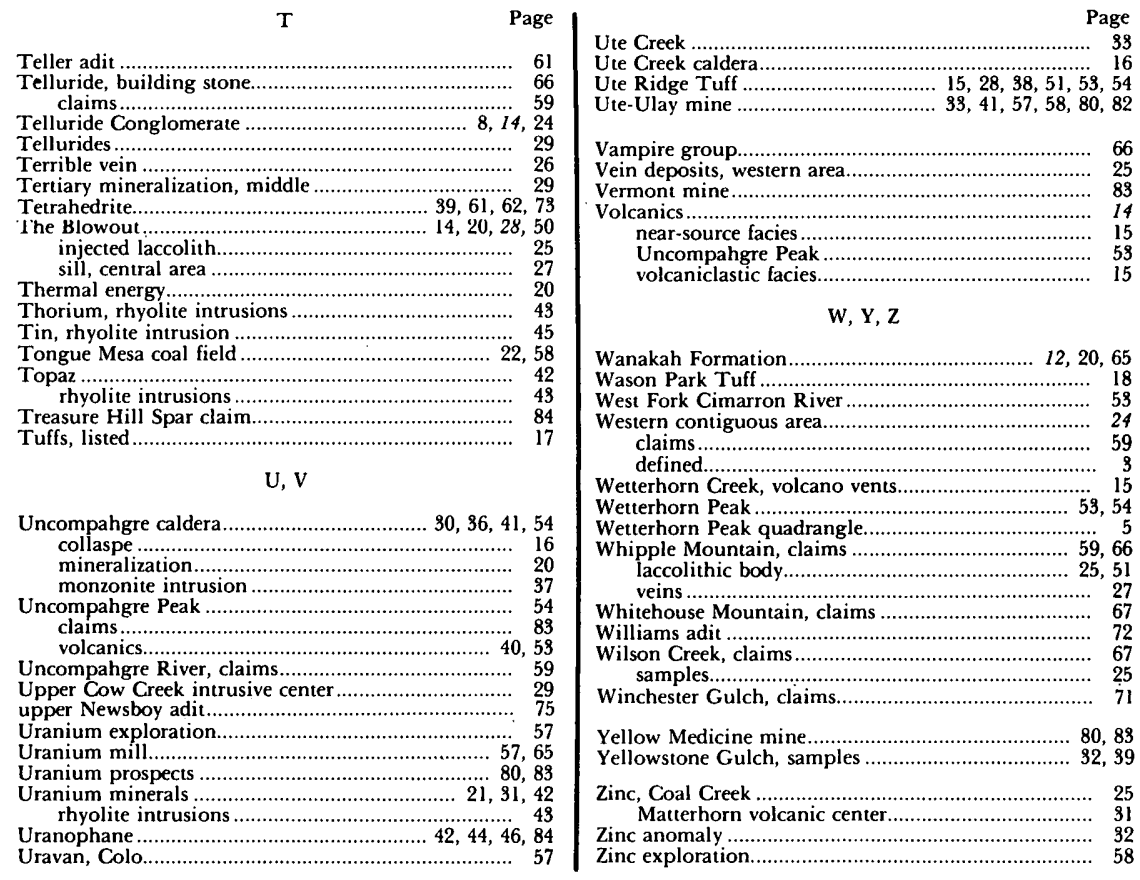

